Universidade de São Paulo

Instituto de Astronomia, Geofísica e Ciências Atmosféricas

Departamento de Astronomia

Luander Bernardes

\title{
Exoplanetas, Extremófilos e Habitabilidade
}

São Paulo 

Luander Bernardes

\section{Exoplanetas, Extremófilos e Habitabilidade}

Dissertação apresentada ao Departamento de Astronomia do Instituto de Astronomia, Geofísica

e Ciências Atmosféricas da Universidade de São Paulo como requisito parcial para a obtenção do título de Mestre em Ciências.

Versão corrigida. O original encontra-se disponível na Biblioteca da Unidade e na Biblioteca Digital de Teses e Dissertações da USP (BDTD).

Área de Concentração: Astronomia Orientador:Prof. Dr. Eduardo Janot Pacheco

São Paulo 

à minha família e amigos ... 



\section{Agradecimentos}

Ao meu orientador Eduardo Janot Pacheco pela ajuda na conclusão deste trabalho.

Aos professores do departamento de Astronomia pela sólida formação.

À minha família pelo apoio e compreensão.

À minha namorada Michele Lidiane da Silva pelo companherismo e ajuda.

Aos meus amigos pelo incentivo.

Aos funcionários do Departamento de Astronomia que contribuíram de várias maneiras para meu bem estar.

Ao $\mathrm{CNPq}$ pelo apoio financeiro.

Esta tese/dissertação foi escrita em IATEX com a classe IAGTESE, para teses e dissertações do IAG. 

"A vida precisa do vazio: a lagarta dorme num vazio chamado casulo até se transformar em borboleta. A música precisa de um vazio chamado silêncio para ser ouvida. Um poema precisa do vazio da folha de papel em branco para ser escrito. E as pessoas, para serem belas e amadas, precisam ter um vazio dentro delas. A maioria acha o contrário; pensa que o bom é ser cheio. Essas são as pessoas que se acham cheias de verdades e sabedoria e falam sem parar. São umas chatas quando não são autoritárias. Bonitas são as pessoas que falam pouco e sabem escutar. A essas pessoas é fácil amar. Elas estão cheias de vazio. E é no vazio da distância que vive a saudade..."

Rubem Alves

"Se não existe vida fora da Terra, então o universo é um grande desperdício de espaço."

Carl Sagan 



\section{Resumo}

O principal objetivo do trabalho é estimar a possibilidade de sobrevivência de microorganismos extremófilos na superfície de exoplanetas conhecidos, assim como na superfície de seus eventuais satélites naturais. Foi utilizado um modelo que simula a atmosfera terrestre primordial, composta principalmente por nitrogênio, água e dióxido de carbono. E em se tratando de extremófilos, esses cálculos não foram limitados à Zona Habitável dos sistemas planetários, pois esse conceito foi estendido para uma região mais ampla, a "Zona Extremófila", onde a vida pode existir. Extremófilos são micro-organismos terrestres que vivem sob condições extremas de temperatura, nível de radiação, umidade, pressão, salinidade, $\mathrm{pH}$, etc... Eles são candidatos naturais para habitarem meios ditos extraterrestres onde tais condições são eventualmente encontradas. Alguns exemplos desses ambientes em nosso sistema solar são: Marte, Titã (satélite de Saturno) e Europa (satélite de Júpiter).

Há algumas centenas de planetas orbitando outras estrelas (exoplanetas) e a maioria deles são gigantes gasosos, em particular Hot Jupiters. A temperatura superficial de um planeta depende fortemente de seu albedo, de sua distância orbital, de condições geodinâmicas intrínsecas, além do tipo espectral de sua estrela hospedeira. A estimativa dessa temperatura foi obtida considerando o ciclo silicato-carbono e um balanço de energia global, que contribuiram para se obter estimativas da pressão parcial atmosférica devido ao $\mathrm{CO}_{2}$ e da temperatura média, na superfície dos planetas e/ou de seus satélites hipotéticos. Os eventuais satélites naturais de planetas gigantes podem abrigar vida e essa possibilidade foi testada através da análise das condições de estabilidade orbital desses corpos celestes. Os resultados deste trabalho deverão fornecer subsídios para a hipótese da panspermia. 



\section{Abstract}

The main objective of this study is to estimate the chance of survival of microorganisms (extremophiles) on the surface of known exoplanets, as well as on the surface of its potential natural satellites. We used a model that simulates the primordial atmosphere composed by, primarily, nitrogen, water and carbon dioxide. And when it comes to extremophiles, these calculations were not limited to the Habitable Zone of planetary systems, since this concept was extended to a wider region, the "Extremophile Zone", where life can exist. Extremophiles are terrestrial microorganisms living under extreme conditions of temperature, light level, humidity, pressure, salinity, pH, etc ... They are natural candidates for living in habitats considered extraterrestrials where such conditions are encountered eventually. Examples of such environments in our solar system are: Mars, Titan (moon of Saturn) and Europe (satellite of Jupiter).

There are hundreds of planets orbiting other stars (exoplanets) and most of them are gas giants, particularly Hot Jupiters. The surface temperature of a planet/moon depends heavily on its albedo, its orbital distance, of geodynamic conditions intrinsic, in addition to the spectral type of their host star. The estimate of this temperature was obtained considering the carbon-silicate cycle and a global energy balance, which contributed to obtain estimates of the partial pressure due to atmospheric $\mathrm{CO}_{2}$ and the average temperature on the surface of planets and/or their hypothetical satellites. Natural satellites of giant planets may harbor life, and this possibility was tested by analyzing the conditions of orbital stability of these heavenly bodies. The results of this study should provide support for the hypothesis of panspermia. 



\section{Lista de Figuras}

1.1 Relação entre a massa e o semi-eixo orbital maior dos exoplanetas conhecidos atualmente. Fonte: Exoplanets Data Explorer. . . . . . . . . . . . . . 30

1.2 Esquema representando a história do universo. Fonte: NASA / WMAP Science Team. . . . . . . . . . . . . . . . . . . . . . . .

1.3 Formação planetária ao redor do disco estelar. (a): fotografia do disco em torno da estrela Beta Pictoris. O painel superior mostra a imagem real no espectro visível. Na imagem inferior vê-se a ligeira deformação do disco ocasionada pela interação gravitacional com o planeta. Fonte: C. Burrows and J. Krist (STScI), WFPC2 IDT Team, NASA, ESA. (b): imagem do disco de Beta Pictoris no infravermelho próximo. Observa-se a formação de planetas ao redor de seu disco. Fontes: ESO/A.-M. Lagrange et al.. . . . .

1.4 Formação do satélite natural terrestre. (a): simulação da colisão entre um protoplaneta e a Terra, com a consequente formação da Lua. Observa-se os resultados projetados para o plano do impacto em intervalos de tempo de 0,3, 0, 7, 1, 4, 1, 9, 3, 0, 3, 9, 5, 0, 7, 1, 11,6, 17 e 23 horas após o evento. (b): concepção artística do evento. Fontes: Canup e Asphaug, 2001; Jynette R.

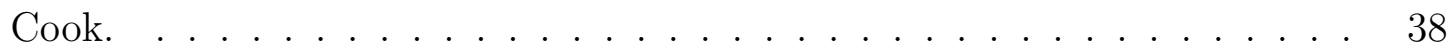

1.5 Diagrama Hertzsprung-Russel. Fonte: Powell (2009). . . . . . . . . . . . . 41

1.6 Late Heavy Bombardment. Na figura são mostradas as interpretações do período de bombardeamento pesado obtidas através de dados lunares. Processos contínuos a 50 milhões de anos (Wilhelms, 1987); 100 milhões de anos (Neukum et al., 2001); cataclismas simples (Rider 2002, 2003); cataclismas múltiplos (Tera et al., 2007). Fonte: Zahnle et al., 2007. . . . . . . . . . . . 
1.7 Árvore filogenética da vida baseada no sequenciamento do RNA ribossômico. Fonte: Madigan et al. (2012), p. 36. . . . . . . . . . . . . . . . 47

2.1 Modelo espectral representativo do Sol e seus planetas, observados a uma distância de dez parsecs. Fonte: Marais et al., 2002. . . . . . . . . . . . . . 51

2.2 Representação esquemática do método de detecção via velocimetria radial. 52

2.3 Representação do método de detecção através de trânsitos planetários. Observase a queda da luminosidade estelar devido ao eclipse planetário. Fonte: ESO

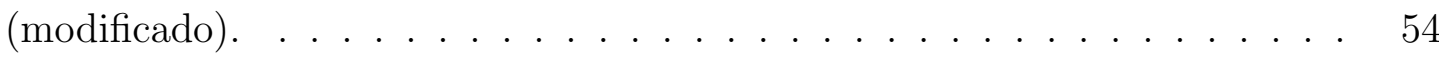

2.4 Representação do pico adicional à curva de luz estelar quando se utiliza o método de detecção através de microlente gravitacional. Na figura, B representa o brilho aparente do objeto fonte. O segundo pico na curva de luz ocorre devido a presença de um exoplaneta. . . . . . . . . . . . . . 55

2.5 Número de exoplanetas descobertos nos últimos anos. Fonte: www.exoplanet.eu. 57

2.6 Massa dos exoplanetas conhecidos versus o semi-eixo orbital maior. Observase o predomínio de planetas massivos. Fonte: www.exoplanet.eu. . . . . . . 58

2.7 Distribuição dos exoplanetas descobertos até o momento. (a): distribuição dos planetas extrasolares em função do semi-eixo orbital maior para um intervalo entre $0,0-1,0 U A$. (b): análise para os planetas com semi-eixos maiores acima de 1,0 UA. Fonte: www.exoplanet.eu. . . . . . . . .

2.8 Excentricidade versus período orbital dos exoplanetas conhecidos. Observase que os planetas próximos de suas estrelas hospedeiras apresentam órbitas circulares. Fonte: Exoplanets Data Explorer. . . . . . . . . . . . . .

2.9 Metalicidade estelar versus semi-eixo maior dos exoplanetas conhecidos. Observa-se as massas das estrelas hospedeiras, assim como as dos planetas que as orbitam. Fonte: Exoplanets Data Explorer. . . . . . . . . .

3.1 Taxa de crescimento em função da temperatura para algumas categorias de extremófilos. Fonte: Madigan et al. (2012), p. 135. . . . . . . . . . . . . 
3.2 Exemplos de ambientes extremos terrestres. (a): Yellowstone National Park, onde há micro-organismos adaptados a sobreviver em altos valores de temperatura. Fonte: Rothschild e Mancinelli (2001). (b): superfície acima do Lago Vostok, local onde acredita-se que extremófilos podem sobreviver. Fonte: M. Studinger, LDEO . . . . . . . . . . . . . . . . . . . . 78

3.3 Organismos extremófilos aptos a suportarem viagens interplanetárias e sobreviverem em condições superficiais hostis. (a): bactéria Deinococcus radiodurans. Fonte: Madigan et al. (2012), p. 41. (b): tardígrado Hypsibius dujardini. Fonte: Bob Goldstein e Vicky Madden, UNC Chapel Hill. . . . .

3.4 Ambientes propensos ao desenvolvimento da vida. (a): concepção artística da possível constituição interna de Titã. Fonte: A. Tavani. (b): comparação entre a superfície da lua Titã e a terrestre. Fonte: NASA/JPL/ESA/University of Arizona and S.M. Matheson. Acesso: 22/08/2012. . . . . . . . . . . . .

3.5 Características do satélite natural Europa. (a): concepção artística de duas possíveis constituições de Europa. A primeira, mostra uma camada de gelo aquecido por convecção a vários quilometros da superfície; a segunda, retrata a existência de um oceano de água líquida abaixo da superfície congelada da lua. Fonte: NASA/JPL. (b): vários aspectos da superfície da lua. Fonte: $\mathrm{NASA} / \mathrm{JPL} / \mathrm{DLR} \ldots \ldots \ldots \ldots \ldots \ldots$

3.6 Sistemas hidrotermais ativos e a provável conexão do conteúdo oceânico da lua com a sua superfície. Fonte: NASA/JPL . . . . . . . . . . .

4.1 Zona Habitável Galáctica para o disco da Via Láctea. Fonte: Lineweaver et al. (2004). . . . . . . . . . . . . . . . . . . . 101

4.2 Representação do ciclo silicato-carbono terrestre global. Fonte: Franck et al. (2001). . . . . . . . . . . . . . . . . . 106

4.3 Efeito runaway greehouse para o Sistema Solar, considerando a luminosidade solar atual. Fonte: Ollivier et al. (2009), p. 231. . . . . . . . . . . . . 108

5.1 Espectro no infravermelho médio dos planetas terrestres do Sistema Solar. Fonte: (Woolf e Angel, 1998). . . . . . . . . . . . . . . . . . . . . . 118

5.2 Perfil de temperatura da atmosfera terrestre. Fonte: Liou (2002), p. 66. . . 122 
5.3 História da composição química da atmosfera terrestre. Observa-se o aumento recente nos níveis de $\mathrm{O}_{2}$, provavelmente devido ao aparecimento dos organismos fotossintetizantes. Fonte: NASA Science News, 2002. . . . . . . 128

5.4 Comportamento do albedo planetário no topo da atmosfera para valores de albedo superficial médio igual a 0,3 e ângulo zenital solar $\mu=60^{\circ}$. (a): valores do albedo para o intervalo de temperatura entre $280<T_{s}<370 \mathrm{~K}$. (b): valores do albedo para o intervalo de temperatura entre $190<T_{s}<280 \mathrm{~K} .131$

5.5 Fluxo infravermelho que deixa o planeta em função da pressão parcial de dióxido de carbono para diversos valores de temperatura. . . . . . . . . . 133

6.1 Limite de Roche para exoplanetas. (a): extensão do raio de Roche para satélites que orbitam planetas gigantes. (b): extensão do raio de Roche para satélites orbitando Super Terras. . . . . . . . . . . . . . . . . . 140

6.2 Processo de formação de luas para planetas do tipo terrestres. Observa-se que não há luas capazes de reter atmosfera para semi-eixos orbitais distantes do limite de Domingos. A figura ainda indica a posição aproximada do satélite natural terrestre. . . . . . . . . . . . . . . . . . 14

6.3 A figura aponta a região em torno de um planeta gasoso semelhante a Júpiter onde existe a possibilidade de sobrevivência de micro-organismos extremófilos na superfície de seu satélite hipotético com características de Europa. . . . . . . . . . . . . . . . . . . . . . . 148

6.4 Expansão do conceito de habitabilidade. É considerado objeto em condições otimizadas de habitabilidade somente aqueles que satisfazem a intersecção dos três modelos: atmosférico, estabilidade orbital e geodinâmico. Microorganismos extremófilos podem sobreviver além desse limite. . . . . . . . . 149

7.1 Zonas Habitável e Extremófila contínuas para o Sistema Solar. L.I e L.E são os limites interno e externo das Zonas Habitável (Z.H) e Extremófila (Z.E) do sistema. . . . . . . . . . . . . . . . . . . . . 152 
7.2 Análise das condições de habitabilidade para o Sistema Solar: (a) e (b) mostram as Zonas Habitável e Extremófila em função da pressão de dióxido de carbono para o Sistema Solar em períodos de tempo aproximados de 3, 8, 4,6 e 6,5 bilhões de anos respectivamente. . . . . . . . . . . . 153

7.3 Zonas Habitável e Extremófila contínuas para o Sistema Extrasolar Gliese 581. L.I e L.E são os limites interno e externo das Zonas Habitável (Z.H) e Extremófila (Z.E) do sistema. . . . . . . . . . . . . . .

7.4 Análise das condições de habitabilidade para o Sistema Gliese 581:(a) e (b) mostram as Zonas Habitável e Extremófila em função da pressão de dióxido de carbono para o Sistema Gliese 581 em períodos de tempo aproximados de 2, 0, 5, 0 e 8, 0 bilhões de anos respectivamente. . . . . . . . . . . 156

7.5 Satélites Habitáveis para o exoplaneta Gliese 581d. A abscissa indica a distância orbital do planeta e, a ordenada, a massa de suas prováveis exoluas. As curvas indicam a massa máxima que as exoluas podem apresentar dentro do limite $q=0,01 \ldots \ldots \ldots \ldots$. . . . . . . . . . . . . . 157

7.6 Zonas Habitável e Extremófila contínuas para o Sistema Extrasolar HD 37124. L.I e L.E são os limites interno e externo das Zonas Habitável (Z.H) e Extremófila (Z.E) do sistema. . . . . . . . . . . . . . . . . . 159

7.7 Análise das condições de habitabilidade para o Sistema HD 37124: (a) e (b) mostram as Zonas Habitável e Extremófila em função da pressão de dióxido de carbono para o Sistema HD 37124 em períodos de tempo aproximados de 3,5, 6,0 e 8,0 bilhões de anos respectivamente. . . . . . . . . . .

7.8 Satélites Habitáveis para o exoplaneta HD 37124c. A abscissa indica a distância orbital do planeta e, a ordenada, a massa de suas prováveis exoluas. A curva indica a massa máxima que as exoluas podem apresentar dentro do limite $q=0,01$. Acima desse limite é possível valores maiores ou menores que uma massa terrestre. . . . . . . . . . . . . . . . . . . . 160

7.9 Zonas Habitável e Extremófila contínuas para o Sistema Extrasolar Gliese 667C. L.I e L.E são os limites interno e externo das Zonas Habitável (Z.H) e Extremófila (Z.E) do sistema. . . . . . . . . . . . . . . . . 161 
7.10 Análise das condições de habitabilidade para o Sistema Gliese 667C: (a) e (b) mostram as Zonas Habitável e Extremófila em função da pressão de dióxido de carbono para o Sistema Gliese $667 C$ em períodos de tempo aproximados de 2,0,5,0 e 8,0 bilhões de anos respectivamente. . . . . . . . . 162

7.11 Satélites Habitáveis para o exoplaneta Gliese $667 C c$. A abscissa indica a distância orbital do planeta e, a ordenada, a massa de suas prováveis exoluas. As curvas indicam a massa máxima que as exoluas podem apresentar dentro do limite $q=0,01 \ldots \ldots \ldots \ldots$. . . . . . . . . . . . . . 163

7.12 Zonas Habitável e Extremófila contínuas para o Sistema Extrasolar HD 85512b. L.I e L.E são os limites interno e externo das Zonas Habitável (Z.H) e Extremófila (Z.E) do sistema. . . . . . . . . . . . . . . . . . . . . . 164

C.1 Análise da habitabilidade para o Sistema Gliese 876: (a) e (b) mostram as Zonas Habitável e Extremófila contínuas e o valor aproximado da massa máxima de uma eventual exolua em função do semi-eixo maior do planeta.

C.2 Análise da habitabilidade para o Sistema Gliese 876: (a) e (b) mostram as Zonas Habitável e Extremófila em função da pressão de dióxido de carbono para o sistema em épocas aproximadas de 2,5, 7,5 e 9,0 bilhões de anos, respectivamente.

C.3 Análise da habitabilidade para o Sistema HD 10697: (a) e (b) mostram as Zonas Habitável e Extremófila contínuas e o valor aproximado da massa máxima de uma eventual exolua em função do semi-eixo maior do planeta.

C.4 Análise da habitabilidade para o Sistema HD 10697: (a) e (b) mostram as Zonas Habitável e Extremófila em função da pressão de dióxido de carbono para o sistema em épocas aproximadas de 3,0,6,9 e 9,0 bilhões de anos respectivamente.

C.5 Análise da habitabilidade para o Sistema HD 11506: (a) e (b) mostram as Zonas Habitável e Extremófila contínuas e o valor aproximado da massa máxima de uma eventual exolua em função do semi-eixo maior do planeta. 
C.6 Análise da habitabilidade para o Sistema HD 11506: (a) e (b) mostram as Zonas Habitável e Extremófila em função da pressão de dióxido de carbono para o sistema em épocas aproximadas de 2,0, 5,4 e 7,0 bilhões de anos respectivamente. . . . . . . . . . . . . . . . . . 197

C.7 Análise da habitabilidade para o Sistema HD 141937: (a) e (b) mostram as Zonas Habitável e Extremófila contínuas e o valor aproximado da massa máxima de uma eventual exolua em função do semi-eixo maior do planeta.

C.8 Análise da habitabilidade para o Sistema HD 141937: (a) e (b) mostram as Zonas Habitável e Extremófila em função da pressão de dióxido de carbono para o sistema em épocas aproximadas de 2,0, 5,0 e 7,0 bilhões de anos respectivamente. . . . . . . . . . . . . . . . . . . 198

C.9 Análise da habitabilidade para o Sistema HD 183263: (a) e (b) mostram as Zonas Habitável e Extremófila contínuas e o valor aproximado da massa máxima de uma eventual exolua em função do semi-eixo maior do planeta.

C.10 Análise da habitabilidade para o Sistema HD 183263: (a) e (b) mostram as Zonas Habitável e Extremófila em função da pressão de dióxido de carbono para o sistema em épocas aproximadas de 3,0,5,0 e 8,5 bilhões de anos respectivamente. . . . . . . . . . . . . . . . . . . 199

C.11 Análise da habitabilidade para o Sistema HD 202206: (a) e (b) mostram as Zonas Habitável e Extremófila contínuas e o valor aproximado da massa máxima de uma eventual exolua em função do semi-eixo maior do planeta.

C.12 Análise da habitabilidade para o Sistema HD 202206: (a) e (b) mostram as Zonas Habitável e Extremófila em função da pressão de dióxido de carbono para o sistema em épocas aproximadas de 2,0,5,0 e 8,0 bilhões de anos respectivamente. . . . . . . . . . . . . . . . 200

C.13 Análise da habitabilidade para o Sistema HD 213240: (a) e (b) mostram as Zonas Habitável e Extremófila contínuas e o valor aproximado da massa máxima de uma eventual exolua em função do semi-eixo maior do planeta. 
C.14 Análise da habitabilidade para o Sistema HD 213240: (a) e (b) mostram as Zonas Habitável e Extremófila em função da pressão de dióxido de carbono para o sistema em épocas aproximadas de 2,0, 5,0 e 7,0 bilhões de anos respectivamente. . . . . . . . . . . . . . . . . 201

C.15 Análise da habitabilidade para o Sistema HD 222582: (a) e (b) mostram as Zonas Habitável e Extremófila contínuas e o valor aproximado da massa máxima de uma eventual exolua em função do semi-eixo maior do planeta.

C.16 Análise da habitabilidade para o Sistema HD 222582: (a) e (b) mostram as Zonas Habitável e Extremófila em função da pressão de dióxido de carbono para o sistema em épocas aproximadas de 3,0, 6,0 e 8,0 bilhões de anos respectivamente. . . . . . . . . . . . . . . . . . . 202

C.17 Análise da habitabilidade para o Sistema HD 38801: (a) e (b) mostram as Zonas Habitável e Extremófila contínuas e o valor aproximado da massa máxima de uma eventual exolua em função do semi-eixo maior do planeta.

C.18 Análise da habitabilidade para o Sistema HD 38801: (a) e (b) mostram as Zonas Habitável e Extremófila em função da pressão de dióxido de carbono para o sistema em épocas aproximadas de 2,0, 4,6 e 6,0 bilhões de anos respectivamente. . . . . . . . . . . . . . . . 203

C.19 Análise da habitabilidade para o Sistema HD 50554: (a) e (b) mostram as Zonas Habitável e Extremófila contínuas e o valor aproximado da massa máxima de uma eventual exolua em função do semi-eixo maior do planeta.

C.20 Análise da habitabilidade para o Sistema HD 50554: (a) e (b) mostram as Zonas Habitável e Extremófila em função da pressão de dióxido de carbono para o sistema em épocas aproximadas de 2,0, 4,6 e 7,0 bilhões de anos respectivamente. . . . . . . . . . . . . . . . . . 204

C.21 Análise da habitabilidade para o Sistema Kepler 22b: (a) e (b) mostram as Zonas Habitável e Extremófila contínuas e o valor aproximado da massa máxima de uma eventual exolua em função do semi-eixo maior do planeta. 
C.22 Análise da habitabilidade para o Sistema Kepler 22b: (a) e (b) mostram as Zonas Habitável e Extremófila em função da pressão de dióxido de carbono para o sistema em épocas aproximadas de 2,0, 3,0 e 4,6 bilhões de anos respectivamente. . . . . . . . . . . . . . . . . . . 205

C.23 Análise da habitabilidade para o Sistema mu Ara: (a) e (b) mostram as Zonas Habitável e Extremófila contínuas e o valor aproximado da massa máxima de uma eventual exolua em função do semi-eixo maior do planeta. 206

C.24 Análise da habitabilidade para o Sistema mu Ara: (a) e (b) mostram as Zonas Habitável e Extremófila em função da pressão de dióxido de carbono para o sistema em épocas aproximadas de 2,5, 6,4 e 8,0 bilhões de anos respectivamente. . . . . . . . . . . . . . . 206 



\section{Lista de Tabelas}

2.1 Classificação dos planetas baseado valores de suas massas . . . . . . . . . . 62

3.1 Extremófilos terrestres e seus habitats extremos . . . . . . . . . . . 75

5.1 Propriedades atmosféricas planetárias . . . . . . . . . . . . . . . . 117

5.2 Principais gases constituintes da atmosfera terrestre . . . . . . . . . . . . 119

5.3 Composição atmosférica dos planetas gigantes do Sistema Solar . . . . . . 120

6.1 Características dos principais satélites do Sistema Solar . . . . . . . . . . 138

7.1 Habitabilidade para o Sistema Solar . . . . . . . . . . . . . . . . . 153

7.2 Habitabilidade para o Sistema Extrasolar Gliese 581 . . . . . . . . . . . 157

7.3 Habitabilidade para o Sistema Extrasolar HD 37124 . . . . . . . . . . . . . 161

7.4 Habitabilidade para o Sistema Extrasolar Gliese $667 C$. . . . . . . . . . . . 163

7.5 Habitabilidade para o Sistema Extrasolar HD 85512 . . . . . . . . . . . . . 164

B.1 Algumas das características dos sistemas extrasolares analisados. . . . . . . 193

B.2 Algumas características do conjunto de exoplanetas e suas eventuais exoluas. 194 



\section{Sumário}

1. Introdução . . . . . . . . . . . . . . . . . . . . . . . . . . . 29

1.1 Astrobiologia . . . . . . . . . . . . . . . . . . 30

1.2 Primeiras Estruturas do Universo . . . . . . . . . . . . . . . . . . . . 32

1.3 Sistema Solar . . . . . . . . . . . . . . . . . . . . . . . 34

1.4 Estrelas da Sequência Principal . . . . . . . . . . . . . . . . . . . . . 39

1.5 Terra Primitiva e Vida . . . . . . . . . . . . . . . . . . . . . 43

2. Exoplanetas . . . . . . . . . . . . . . . . . . . . . . . . . 49

2.1 Breve Histórico . . . . . . . . . . . . . . . . . . . . . . . . . 50

2.2 Métodos de Detecção . . . . . . . . . . . . . . . . . . . . . . 51

2.2.1 Velocidade Radial (Método Doppler) . . . . . . . . . . . . 52

2.2.2 Trânsito Planetário . . . . . . . . . . . . . . . . . . 53

2.2.3 Astrometria de Precisão . . . . . . . . . . . . . . . . . . . . . 54

2.2.4 Microlentes Gravitacionais . . . . . . . . . . . . . . . . . . 55

2.2.5 Atraso nos Sinais de Pulsares . . . . . . . . . . . . . . . 56

2.3 Exoplanetas Observados . . . . . . . . . . . . . . . . . 56

2.4 Taxonomia Planetária . . . . . . . . . . . . . . . . . . . . 61

2.4.1 Planetas, Satélites e Objetos do Sistema Solar . . . . . . . . . . . 63

2.4.2 Planetas Extrasolares Rochosos . . . . . . . . . . . . . . . . . 64

2.4.3 Planetas Extrasolares Oceânicos . . . . . . . . . . . . . . . . 66

2.4.4 Planetas Extrasolares Gigantes . . . . . . . . . . . . . 67

2.5 Formação Planetária . . . . . . . . . . . . . . . . . . . . . . . 68 
2.6 Processos Migratórios

3. Extremófilos . . . . . . . . . . . . . . . . . . . 73

3.1 Categoria de Extremófilos e Definição de Ambiente Extremo . . . . . . . . 74

3.1.1 Extremófilos e Ambientes de Temperaturas Extremas . . . . . . . . 75

3.1.2 Extremófilos e Ambientes Salinos . . . . . . . . . . . . . . . . 79

3.1.3 Extremófilos e Ambientes Ácido e Alcalino . . . . . . . . . . . . . . 80

3.1.4 Extremófilos e Ambientes a Altas Pressões . . . . . . . . . . . . . . 81

3.1.5 Extremófilos e Dessecação . . . . . . . . . . . . . . . 82

3.1 .6 Extremófilos e Radiação . . . . . . . . . . . . . . . . . . . . 82

3.1.7 Extremófilos e Altas Concentrações de Oxigênio . . . . . . . . . . . 83

3.1.8 Extremófilos e Ambientes Subterrâneos . . . . . . . . . . . . . . . 84

3.2 Micro-organismos Extremófilos Candidatos a Habitarem Ambientes Extra-

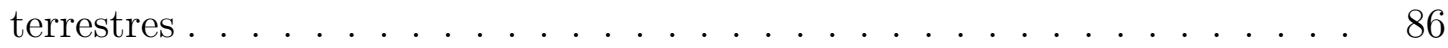

3.2.1 Ferroplasma acidarmanus ................. 86

3.2.2 Deinococcus radiodurans . . . . . . . . . . . . . . . 86

3.2.3 Pyrolobus fumarii . . . . . . . . . . . . . . . . . . 87

3.2.4 Hesiocaeca methanicola . . . . . . . . . . . . . . . . . . . 87

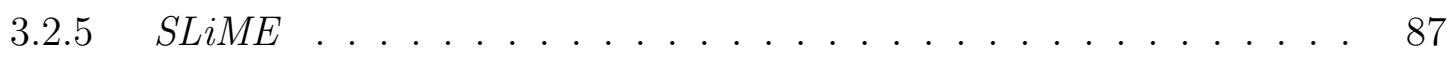

3.2.6 Tardigrados . . . . . . . . . . . . . . . . . . . . 88

3.3 Ambientes Extremos no Sistema Solar . . . . . . . . . . . . . . . . . . . 89

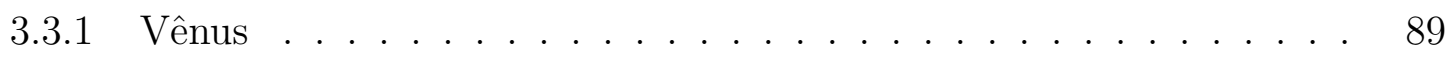

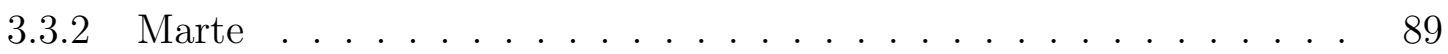

3.3.3 Os Satélites do Sistema Solar Propensos a Abrigar Vida . . . . . . 90

3.3.3.1 Titã . . . . . . . . . . . . . . . . . . 91

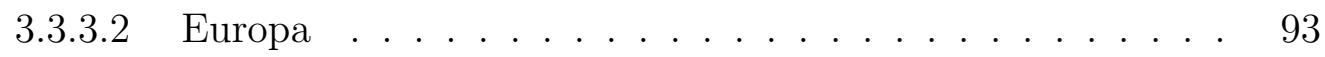

3.3 .3 .3 Io . . . . . . . . . . . . . . . . . 96

3.3.3.4 Enceladus . . . . . . . . . . . . . . . . 96

3.4 Sobrevivência de Organismos no Espaço . . . . . . . . . . . . . . . . . 96

3.5 Extremófilos e Panspermia . . . . . . . . . . . . . . . . . . . . 99 
4. Habitabilidade . . . . . . . . . . . . . . . . . . . . . . . . . . . 101

4.1 Breve Histórico ． . . . . . . . . . . . . . . . . . . . . . . . . . . . 102

4.2 Aspectos Gerais sobre o Conceito de Habitabilidade . . . . . . . . . . . 103

4.3 Ciclo Silicato-Carbono . . . . . . . . . . . . . . . . . . . . . . . . 104

4.4 Limite Interno da Zona Habitável (Baseado na Observação do Sistema Solar)107

4.5 Limite Externo da Zona Habitável (Baseado na Observação do Sistema Solar) 109

4.6 Zona Habitável Contínua . . . . . . . . . . . . . . . . . . . . . . . . . . . . 109

4.7 Zona Habitável ao redor de Planetas Gigantes . . . . . . . . . . . . . . . 110

4.8 Estrelas Favoráveis à Habitabilidade ． . . . . . . . . . . . . . . . . . . . 110

4.9 Massa, Obliquidade, Tectonismo e Habitabilidade . . . . . . . . . . . . 112

4.10 Zona Habitável e Zona Extremófila neste Trabalho . . . . . . . . . . . . . . 113

5. Atmosferas Planetárias . . . . . . . . . . . . . . . . . . . . 115

5.1 Composição das Atmosferas Planetárias . . . . . . . . . . . . . . . . . . . 116

5.2 A Estrutura Vertical da Atmosfera . . . . . . . . . . . . . . . . . . . 120

5.3 Escape Atmosférico . . . . . . . . . . . . . . . . . . . . . . . . . 123

5.3.1 Escape Atmosférico Hidrostático Térmico . . . . . . . . . . . . . . 124

5.3 .2 Escape Atmosférico Hidrodinâmico Térmico . . . . . . . . . . . . . 125

5.3.3 Mecanismos não Térmicos de Escape Atmosférico . . . . . . . . . 126

5.4 Evolução da Atmosfera de Planetas Rochosos . . . . . . . . . . . . . . . 127

5.5 Simulando a Atmosfera Terrestre . . . . . . . . . . . . . . . . . . . 129

6. Satélites Naturais Extrasolares . . . . . . . . . . . . . . . . . . . . . 135

6.1 Exoluas e Astrobiologia . . . . . . . . . . . . . . . . . . . 136

6.2 Processo de Formação de Satélites Naturais (Exoluas) . . . . . . . . . . 136

6.3 Composição dos Satélites do Sistema Solar . . . . . . . . . . . . . . . . 138

6.4 Estabilidade de Satélites Naturais Extrasolares . . . . . . . . . . . . . . . . 139

6.5 Habitabilidade para Satélites Naturais Extrasolares . . . . . . . . . . . 143

6.6 Conteúdo Volátil de Satélites Naturais Extrasolares . . . . . . . . . . . . . 143

6.7 Zonas de Habitabilidade de Satélites Naturais Extrasolares . . . . . . . . . 145

7. Análise. . . . . . . . . . . . . . . . . . . . . . . . . . 151

7.1 Habitabilidade para o Sistema Solar . . . . . . . . . . . . . . . . 151 
7.2 Gliese $581 d$, um planeta habitável? . . . . . . . . . . . . . . . . . 154

7.3 Satélite extrasolar orbitando o exoplaneta HD 37124c? . . . . . . . . . . . 158

7.4 Gliese $667 C c$, o melhor candidato a abrigar vida? . . . . . . . . . . . . 161

7.5 O Planeta HD $85512 b$ está realmente na Zona Habitável? . . . . . . . . . . 164

7.6 Outros Sistemas Extrasolares podem abrigar vida extremófila? . . . . . . . 165

8. Conclusões . . . . . . . . . . . . . . . . . . . . . . . . 167

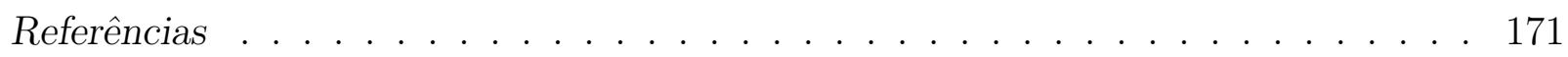

$\begin{array}{ll}\text { Apêndice } & 189\end{array}$

A. Evolução dos Satélites Naturais (Exoluas) . . . . . . . . . . . . . . 191

B. Sistemas Extrasolares Analisados . . . . . . . . . . . . . . . . . 193

B.1 Características dos Sistemas Extrasolares . . . . . . . . . . . . . . 193

B.2 Características dos Exoplanetas . . . . . . . . . . . . . . . . 194

C. Análise dos Exoplanetas . . . . . . . . . . . . . . . . . . . . . . . . . . 195 
Capítulo 1

\section{Introdução}

Foram descobertos, até junho de 2012, 776 planetas orbitando outras estrelas (exoplanetas). A grande maioria deles é constituída por gigantes gasosos, em particular Hot Jupiters (raios orbitais pequenos), já que foram detectados pelo método da velocitometria: trata-se de medir o efeito Doppler da perturbação gravitacional que o planeta causa na estrela central e estimar a massa dele via solução dinâmica do sistema. A amostra de planetas extrasolares conhecidos tem, pois, forte viés, na medida em que se descobriu preferencialmente planetas mais massivos e/ou mais próximos das estrelas centrais, como descrito pela Lei de Newton. A figura 1.1 mostra a relação entre a massa e o semi-eixo orbital maior dos planetas descobertos até o momento.

Esse cenário está sendo consideravelmente alterado atualmente graças à descoberta de exoplanetas pelo método mais isento dos trânsitos, com os satélites CoRoT (projeto do qual o Brasil é colaborador) e Kepler. Em particular, esse método permite encontrar planetas pequenos e rochosos como a Terra, muito mais interessantes do ponto de vista da Astrobiologia.

Extremófilos são micro-organismos terrestres que vivem sob condições extremas de temperatura, nível de radiação, umidade, pressão, salinidade, pH, etc. Eles são candidatos naturais para habitarem meios extraterrestres onde essas condições são eventualmente encontradas. Exemplos em nosso sistema solar são: Marte, Titã (satélite de Saturno) e Europa (satélite de Júpiter). Neste trabalho, estimar-se-ão as temperaturas nas superfícies de uma amostra de exoplanetas conhecidos e de seus eventuais satélites, utilizando um modelo de atmosfera terrestre com a finalidade de verificar a possibilidade de sobrevivência de extremófilos nesses ambientes. E, em se tratando de extremófilos, essa previsão não será 


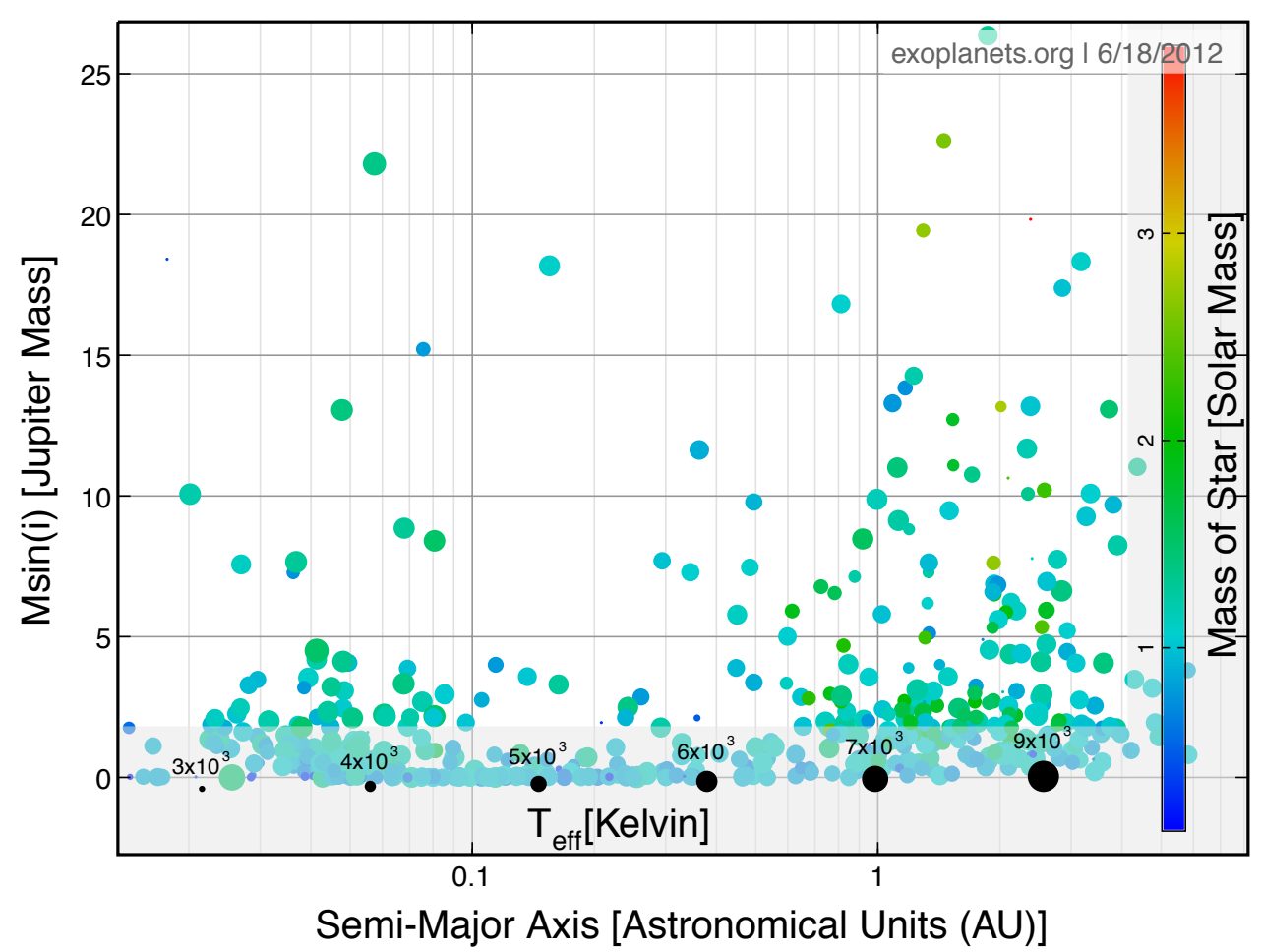

Figura 1.1: Relação entre a massa e o semi-eixo orbital maior dos exoplanetas conhecidos atualmente. Fonte: Exoplanets Data Explorer.

limitada à Zona Habitável (Kasting et al., 1993) dos sistemas planetários, pois esse conceito será estendido para uma região mais ampla, a "Zona Extremófila" (Janot-Pacheco et al., 2009), onde esse tipo vida poderia existir. Os resultados deste trabalho deverão fornecer subsídios para a hipótese da panspermia (vide seção 3.5).

Para realizar este estudo multidisciplinar foi necessário articular conceitos de diversas áreas científicas, como por exemplo, a biologia, a astronomia, a física de partículas, a geofísica, a planetologia, a química, entre outras, a fim de se entender e elaborar novas hipóteses baseadas nos conhecimentos já adquiridos por meio da observação das caracterísitcas físicas e químicas do Sistema Solar.

\subsection{Astrobiologia}

A Astrobiologia pode ser entendida como uma área de pesquisa dedicada aos estudos relativos à compreensão da origem e evolução da vida no universo. Com características distintas da biologia clássica, focalizada nos estudos da vida observada na Terra, a Astrobiologia traz como proposta a extensão destes conhecimentos e procura formular hipóteses 
a fim de entender o desenvolvimento da vida além dos limites terrestres. Estas características colocam a Astrobiologia frente a questões que sempre foram intrigantes para a humanidade: "Como a vida se orginou?"; "Estamos sós no universo?"; "Qual o futuro da vida na Terra e no universo?".

A descoberta de uma grande quantidade de sistemas planetários em nossa galáxia reforça a possibilidade da existência de muitos planetas localizados nas zonas Habitável ou Extremófila de suas estrelas hospedeiras e a importância dos estudos astrobiológicos destes sistemas, para que se possa ter uma melhor compreensão da presença da vida no universo. Entretanto, as primeiras discussões com enfoque em questões abrangidas pela Astrobiologia, especialmente versando a respeito da pluralidade dos mundos e sobre a possível existência de vida em corpos além da Terra, remontam à Grécia Antiga. Essas ideias já haviam sido discutidas no passado por pensadores como Leucipo (século $V$ a.C), Demócrito (460 - 370 a.C), Epicuro (341 - 270 a.C), Plutarco (46 - 120 d.C), Giordano Bruno (1548-1600), Galileo Galilei (1584-1642), Jonas Kepler (1571-1630), entre outros. Dentre estes, pode-se destacar o historiador Plutarco, que desenvolveu o primeiro esboço do que se conhece hoje como o Princípio de Mediocridade, e Giordano Bruno que, por defender as ideias contidas na obra De l'infinito, Universo e Mondi, de 1584, foi acusado de heresia e executado pela Inquisição. Um fato curioso, e que demonstra a influência e a interferência religiosa nos assuntos relacionados à ciência, é a posição tomada por Galileo ao manifestar-se de forma mais prudente ao discutir o tema relacionado à pluralidade dos mundos em sua obra Carta Sobre as Manchas Solares; nela, aponta para a possibilidade da existência de seres vivos habitando a Lua e outros planetas, porém, não afirma e nem nega a hipótese, deixando a decisão para os ditos "homens mais eruditos". Outro fato curioso é a crença na existência de habitantes em Júpiter demonstrada pelo grande cientista Johanes Kepler (1571-1630) em 1600, evidenciada em um texto em que comenta as extraordinárias descobertas de Galileo Galilei acerca dos satélites de Júpiter. Nota-se que questionamentos relacionados a temas sobre a possibilidade da existência de outros mundos (exoplanetas) espalhados pelo universo e principalmente da própria vida neste vasto espaço, mesmo que de forma imprecisa e até fantasiosa, ocupavam a mente de grandes pensadores. Porém, somente nos séculos posteriores, as discussões ganharam argumentos cientificamente mais embasados. No século XIX, a Teoria da Evolução, baseada no princípio da Seleção Natu- 
ral, desenvolvida independentemente por Charles Darwin (1809-1882) e Alfred R. Wallace (1823 - 1913), eleva a discussão acerca da possibilidade da existência de formas de vida para outras partes do universo - devido ao argumento de que a vida complexa se originou a partir de formas mais simples, através de processos de adaptação -, mesmo com o fato de que seus fundadores não compartilhassem desta crença. Logicamente, no século $X X$, a descoberta de organismos extremófilos e de sua admirável capacidade de sobrevivência e adaptação a ambientes extremos, reforçam a possível veracidade das hipóteses de se encontrar condições de habitabilidade em outros corpos do Sistema Solar e além. Porém, com o avanço das técnicas observacionais e, principalmente, com a confirmação do primeiro sistema extrasolar (Mayor e Queloz, 1995), os temas da pluraridade dos mundos e da possível existência de vida além do ambiente terrestre tornam-se novamente relevantes, apresentanto um caráter interdisciplinar e foco principal desta pesquisa.

\subsection{Primeiras Estruturas do Universo}

A teoria cosmológica moderna oferece ferramentas coerentes para descrever a origem e a evolução do universo de forma satisfatória, assim como o papel notável desempenhado pela temperatura em todas as fases desse processo. De acordo com o modelo do Big Bang, o universo evoluiu a partir de um início quente e denso e, por meio de uma expansão, esfriou e permitiu o aparecimento das primeiras estruturas. O universo primordial era preenchido por níveis extremamente altos de radiação e temperatura. O fenômeno conhecido como bariogênese, responsável pela formação de toda a matéria presente no universo, ocorreu em aproximadamente $10^{-33}$ segundos após o Big Bang. Isso deveu-se ao fato de que o universo havia esfriado o suficiente para que a matéria e a anti-matéria se aniquilassem, convertendo massa de repouso em radiação e deixando um pequeno excesso de matéria. Em aproximadamente $10^{-4}$ segundos após o Big Bang ocorreu a transição quark-hadron, período no qual a energia térmica do universo era baixa o suficiente para permitir que a "sopa quente de quarks" condensasse e permanecesse estável na forma de prótons e nêutrons. Entretanto, somente em aproximadamente 100 segundos após o Big Bang, a nucleossíntese tem início: a energia térmica do universo diminui, permitindo a união entre prótons e nêutrons sob a ação da força nuclear forte, com a consequente formação dos núcleos de elementos mais leves $\left({ }^{1} \mathrm{H},{ }^{2} \mathrm{H},{ }^{3} \mathrm{He},{ }^{4} \mathrm{He},{ }^{7} \mathrm{Li}\right)$. 
Nos primeiros quatrocentos mil anos após o Big Bang, toda a matéria estava em equilíbrio térmico com a imensa quantidade de fótons que preenchia o universo (Radiação Cósmica de Fundo $(C M B))$. Em uma fase posterior, a energia térmica da $C M B$ diminuiu a um nível inferior à energia de ionização do átomo de hidrogênio, o que permitiu à força eletromagnética unir elétrons e prótons para a formação de átomos de hidrogênio. Com a ausência de partículas carregadas para manter o equilíbrio térmico, as temperaturas da matéria e dos fótons comportaram-se de formas distintas: a temperatura dos fótons diminuiu lentamente (de forma proporcional ao inverso do tamanho do universo), enquanto a temperatura da matéria esfriou mais rapidamente (diminuiu em uma taxa aproximadamente proporcional ao quadrado do tamanho do universo). À medida que a temperatura do hidrogênio caiu abaixo da energia do hidrogênio molecular, átomos de hidrogênio nas regiões mais densas formaram as primeiras moléculas de $H_{2}$. Um esquema do processo de evolução do universo pode ser visualizado na figura $1.2^{1}$.

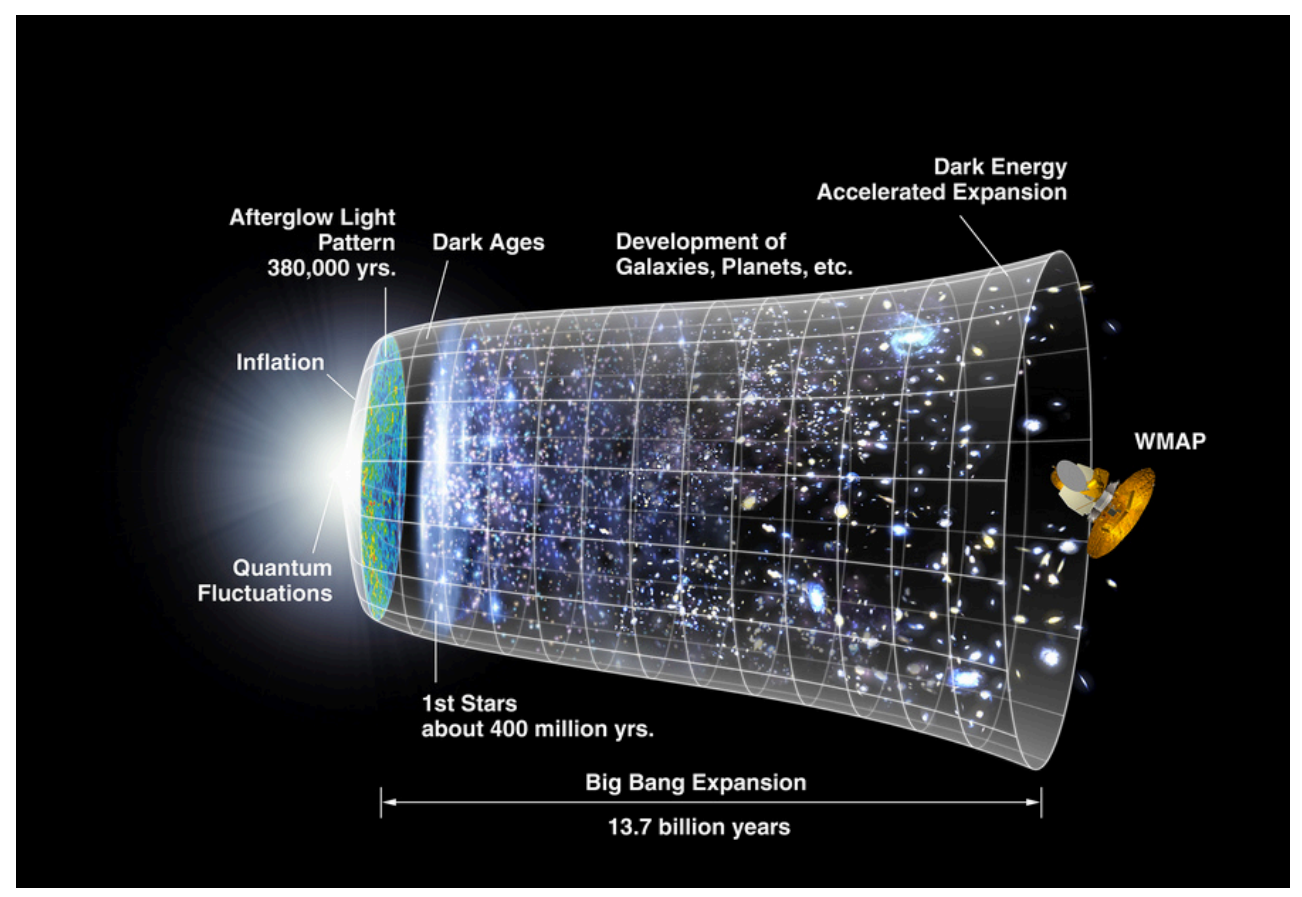

Figura 1.2: Esquema representando a história do universo. Fonte: NASA / WMAP Science Team.

Com a expansão contínua e o consequente esfriamento do universo, nuvens de hidrogênio resfriaram e atingiram temperaturas próximas a $100 \mathrm{~K}$. Neste momento, a energia térmica

\footnotetext{
${ }^{1}$ A figura pode ser acessada em: http://map.gsfc.nasa.gov. Acesso em: 21/07/2012.
} 
foi baixa o suficiente para permitir que a força gravitacional iniciasse o processo de colapso das regiões mais densas do universo, com a conversão da energia potencial gravitacional em energia térmica dissipada pelo espaço. As nuvens colapsaram mais, aqueceram-se e este processo deu origem às primeiras estrelas do universo. Os fótons UV, provenientes dessas primeiras estrelas reionizaram o universo e explosões de supernovas induziram o colapso de outras regiões com altas densidades.

O meio interestelar (ISM) - composto por várias componentes com parâmetros físicos distintos, ou seja, algumas regiões com temperaturas da ordem de $10^{6} \mathrm{~K}$, densidade de $10^{-2}$ partículas por $\mathrm{cm}^{3}$, aquecidas por explosões de supernovas, e outras contendo nuvens moleculares com temperaturas da ordem de 10 a $100 \mathrm{~K}$, permeada por hidrogênio molecular com densidades de algumas centenas a $10^{8}$ partículas por $\mathrm{cm}^{3}$ - é o ambiente onde ocorrem os processos físicos que iniciam a formação dos sistemas planetários.

Apenas 1\% da matéria bariônica observada no universo difere do hidrogênio e do hélio. Os elementos pesados não foram produzidos pelo Big Bang e sim por gerações de estrelas subsequentes, através de reações de fusão. O colapso de nuvens moleculares ricas em elementos pesados foi o responsável pela formação de planetas, corpos rochosos e toda as formas de vida conhecidas. Através de observações recentes de nuvens moleculares gigantes e de discos protoplanetários, foi possível identificar uma grande quantidade de moléculas orgânicas e, a partir dessa constatação, supor que moléculas complexas que constituem o material biológico terrestre podem ter sido incorporadas por corpos originados em regiões semelhantes às destas nuvens (Dutrey et al., 1997; Buhl, 1971).

\subsection{Sistema Solar}

O Sistema Solar formou-se a partir da contração gravitacional de um fragmento de nuvem molecular, constituída por poeira, gás e alguns poucos elementos pesados, processo semelhante ao observado atualmente em outras regiões da Via Láctea e também em outras galáxias (Dutrey et al., 1997). Essas nuvens moleculares espalhadas pelo universo, onde se originaram as primeiras estrelas, são regiões com temperaturas da ordem de $10 K$ a $100 \mathrm{~K}$ e densidades da ordem de 10 a $10^{4} . \mathrm{cm}^{-3}$. O colapso de nuvens semelhantes pode ocorrer se houver um aumento aproximado de um fator de $10^{24}$ e $10^{6}$ nos valores de suas densidade e temperatura, respectivamente (Padmanabhan, 2001, p. 116). Em subregiões 
com altas densidades originadas do colapso inicial, a matéria sofre um processo físico onde a autogravidade supera a pressão do gás (térmica) que se opõe à contração, levando à formação de uma protoestrela. O processo que conduz à formação de subregiões ainda é pouco conhecido. Entretanto, a massa mínima para que ocorra seu colapso, denominada massa mínima de Jeans, pode ser estimada por:

$$
M_{J} \approx 10 \frac{T^{\frac{3}{2}}}{\sqrt{n}} M_{\odot}
$$

onde as variáveis $T$ e $n$ representam a temperatura e a densidade para essas subregiões. Tomando valores característicos desses parâmetros, temperaturas aproximadas de $10 \mathrm{~K}$ e densidades da ordem de $10^{5} . \mathrm{cm}^{-3}$ (Blitz, 1993), encontram-se valores mínimos, logicamente aproximados, para a massa responsável, provavelmente, pela origem de uma protoestrela: $M_{J} \approx 1 M_{\odot}$, onde $M_{\odot}$ é o valor de uma massa Solar. Assim, os fragmentos de nuvens moleculares com valores de massa da ordem de uma massa solar, ou acima, serão candidatos a berços de formação de sistemas planetários.

Simulações mostram que ao redor de estrelas em processo de formação há uma região composta por poeira e gás, denominada disco protoplanetário, onde certamente ocorre a formação de planetas (Beckwith e Sargent, 1993). Observações do gás contido nos discos protoplanetários apontam para um tempo médio de vida dessas componetes que varia aproximadamente entre $10^{6}$ a $10^{7}$ anos (Briceño et al., 2001). O processo de desaparecimento de tais discos pode estar relacionado ao fluxo intenso de radiação UV, oriundo de estrelas vizinhas (estrelas quentes do tipo $\mathrm{O}$ e B) ou com os ventos estelares extremos provindos da estrela central do Sistema (Hollenbach et al., 2000). Estima-se que a formação dos planetas rochosos deva ocorrer em uma escala de tempo entre $10-10^{8}$ anos (Raymond et al., 2011). O processo de formação de planetas localizados a distâncias orbitais maiores, como por exemplo os planetas gigantes do Sistema Solar, apresenta uma escala de tempo variando entre $1-2$ ordens de magnitude menor que a escala de tempo necessária para a formação de planetas rochosos (Touboul et al., 2007). Esse fato pode ser justificado pela presença de maior quantidade de matéria em regiões mais afastadas da estrela central.

A partir do colapso de parte (subregiões) da nuvem molecular que originou o Sistema Solar, denominada nebulosa Solar, formou-se o que se denomina protosol, rodeado por um disco achatado, produto de sua rotação. De acordo com a teoria de formação planetária 
por acresção nuclear, regiões pertencentes ao disco protoplanetário, cuja densidade é elevada, permitem o desenvolvimento de um processo de condensação de grãos e posterior acresção, originando pequenos corpos com extensão de alguns quilômetros, denominados planetesimais. Estes planetesimais continuam crescendo devido a colisões mútuas até que determinadas regiões atinjam uma configuração composta por alguns planetas isolados entre si, apresentando órbitas quase circulares e coplanares, imersos em meio aos planetesimais residuais. O destino dos planetesimais residuais é a dispersão devido às interações gravitacionias com os planetas recém formados. Na figura $1.3^{2}$ é mostrada a possível interação entre um planeta e seu disco protoplanetário.
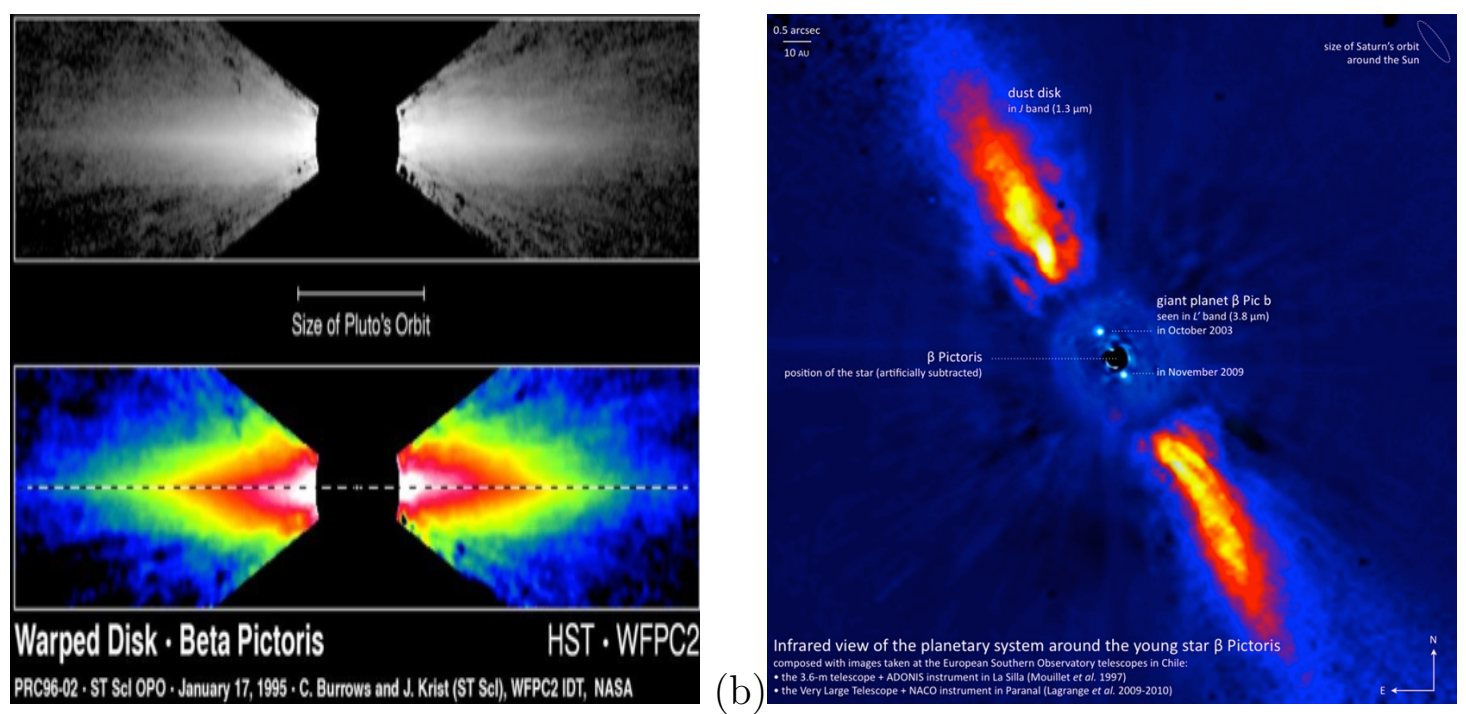

Figura 1.3: Formação planetária ao redor do disco estelar. (a): fotografia do disco em torno da estrela Beta Pictoris. O painel superior mostra a imagem real no espectro visível. Na imagem inferior vê-se a ligeira deformação do disco ocasionada pela interação gravitacional com o planeta. Fonte: C. Burrows and J. Krist (STScI), WFPC2 IDT Team, NASA, ESA. (b): imagem do disco de Beta Pictoris no infravermelho próximo. Observa-se a formação de planetas ao redor de seu disco. Fontes: ESO/A.-M. Lagrange et al..

Há uma nítida dependência radial da temperatura da nebulosa protoestelar, responsável por segregar gases e sólidos. Essa dependência foi estimada por Kenyon e Hartmann (1987):

$$
T_{\text {disco }}(r) \propto r^{-\frac{1}{2}}
$$

A distâncias orbitais menores que $2 U A^{3}$, onde estão localizados os planetas rochosos, a ação do vento solar e as temperaturas suficientemente altas, não permitiram aos elementos

\footnotetext{
${ }^{2}$ As figuras podem ser acessadas em: http://apod.nasa.gov/apod/ap960119.html e www.eso.org/public/images/archive/category/exoplanets/. Acesso: 21/07/2012.

31 unidade astronômica $\sim 1,5.10^{11}$ metros.
} 
como o $\mathrm{C}, \mathrm{N}$ e $\mathrm{O}$, que encontram-se ligados ao hidrogênio na forma de $\mathrm{CH}_{4}, \mathrm{NH}_{3}, \mathrm{H}_{2} \mathrm{O}$, $\mathrm{CO}_{2}$, etc, permanecerem em estado gasoso. Os únicos materiais sólidos responsáveis pela formação dos núcleos planetários foram os materiais refratários, em especial o $\mathrm{Fe}$, o $\mathrm{Ni}$, os silicatos e os metais. Percebe-se através da análise das abundâncias cósmicas que houve pouca matéria disponível para a formação dos núcleos planetários em tais regiões (Grevesse et al., 2005).

Para distâncias orbitais acima de $4 U A$, ao contrário, a menor influência do vento solar e o fato de que as temperaturas eram suficientemente baixas, contribuíram para que elementos como $\mathrm{C}, \mathrm{N}$ e $\mathrm{O}$, condensassem na forma de gelos de $\mathrm{H}_{2} \mathrm{O}, \mathrm{CH}_{4}, \mathrm{NH}_{3}$, etc, e que houvesse uma maior quantidade de material disponível para formar os planetesimais. Nessas regiões, esta quantidade maior de material culminou na formação de núcleos muito maiores que os previstos na formação de planetas rochosos. Quando a massa desses núcleos atinge valores aproximados de dez vezes o valor da massa terrestre, o campo gravitacional torna-se suficientemente intenso para provocar o colapso do material protosolar do disco circundante, constituído basicamente por hidrogênio e hélio. No interior deste disco, localizado no plano equatorial do planeta gigante em processo de formação, houve condições para o surgimento de inúmeros satélites. Planetas gigantes de baixa densidade, localizados nas Zonas Habitável e Extremófila, serão os alvos principais na busca por exoluas neste trabalho.

Dentro do previsto pelos estudo de Kenyon e Hartmann (1987), planetas rochosos localizados próximos às estrelas centrais dos sistemas planetários, também conhecidos como planetas rochosos ou internos, devem ter uma origem inicialmente aquecida e com o passar do tempo experimentarem um processo de resfriamento. Dentre estes, os menores tendem a sofrer esse processo de forma mais brusca, enquanto os maiores, devido à energia gravitacional de acresção e ao decaimento de elementos radioativos, mantêm-se aquecidos, apresentando correntes convectivas em seu manto, atividades vulcânicas, tectonismo e sistemas hidrotermais ativos.

O planeta Terra formou-se a partir de uma bola fundida de aproximadamente $2000 \mathrm{~K}$ a cerca de 4, 56 bilhões anos (Allègre et al., 1995). A maior parte da massa terrestre acrescida dos planetesimais ocorreu nos primeiros 100 milhões de anos de formação da Terra. Com uma superfície inicialmente fundida, a vida não poderia aparecer. A transição entre o 
período de acresção e o período conhecido como heavy bombardment inclui a formação de nosso satélite, a Lua, provavelmente pela colisão com um objeto com a dimensão de Marte há aproximadamente 4,5 bilhões de anos (Hartmam e Davis, 1975; Canup e Asphaug, 2001). Na figura 1.4 são mostrados os detalhes simulados dessa colisão.

(a)
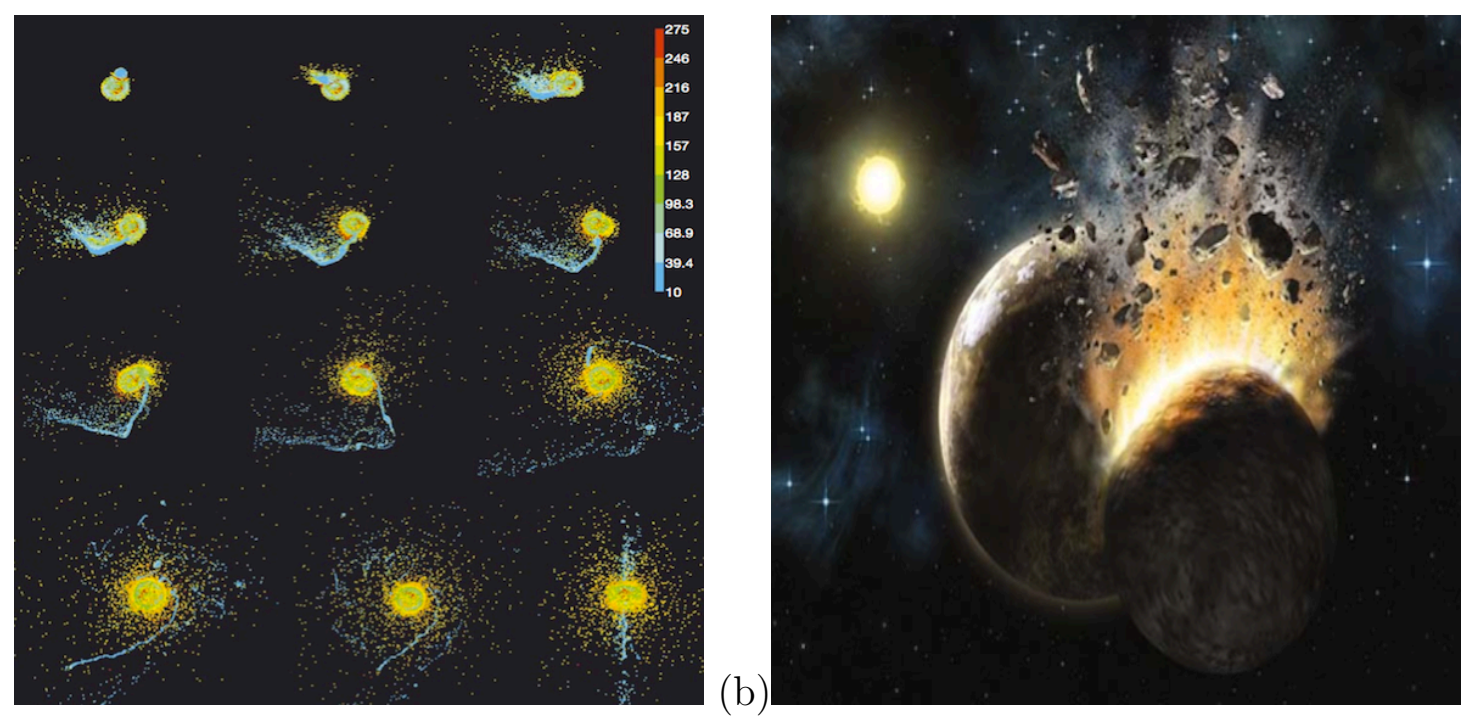

Figura 1.4: Formação do satélite natural terrestre. (a): simulação da colisão entre um protoplaneta e a Terra, com a consequente formação da Lua. Observa-se os resultados projetados para o plano do impacto em intervalos de tempo de $0,3,0,7,1,4,1,9,3,0,3,9,5,0,7,1,11,6,17$ e 23 horas após o evento. (b): concepção artística do evento. Fontes: Canup e Asphaug, 2001; Jynette R. Cook.

A superfície terrestre foi periodicamente vaporizada e recoberta com vapor de rocha atmosférica à temperatura aproximada de $2000 K$ por milhares de anos. Estas condições faziam da superfície terrestre um verdadeiro autoclave, esterelizando e ceifando o desenvolvimento de qualquer forma de vida. O bombardeamento prosseguiu forte até aproximadamente 3, 8 bilhões de anos. Eventos em Mercúrio, Vênus e Marte provavelmente foram similares: um período inicial de intenso bombardeamento e sua posterior diminuição com o arrastamento dos planetesimais. Estas são provavelmente as restrições térmicas que qualquer forma de vida encontrará ao desenvolver-se em exoplanetas com processo de formação semelhante ao da Terra.

Os materiais mais voláteis como a água e os compostos de carbono, importantes para a evolução da vida, foram incorporados tardiamente pela injeção de material oriundo das regiões mais frias do disco protoplanetário solar. A região onde está localizado o cinturão de asteróides corresponde a localidades de menor temperatura (aproximadamente $250 \mathrm{~K}$ ) do disco protoplanetário, e essa característica permitiu a condensação da água e consequente 
formação de corpos sólidos com composição rica em água e gelo. A faixa de transição do disco protoplanetário, que separa as regiões de condensação e não condensação da água, é chamada de snow line. Estudos concluem que, após a formação dos planetas gigantes, os planetesimais residuais vizinhos e ricos em gelo foram dispersos devido à ação das interações gravitacionais e podem ter atingido regiões mais internas, onde estão localizados os planetas terrestres. Essa migração pode ser a responsável pela injeção de grande quantidade de água e compostos orgânicos em planetas do tipo terrestre (Chyba, 1987; Ip e Fernández, 1988). Entretanto, alguns cientistas, pautados em observações da razão entre o conteúdo de deutério e hidrogênio dos cometas Halley, Hayakatake e Hale-Boop, contestam essa hipótese. O valor dessa razão $(D / H)$ para o reservatório de água oceânico é bem conhecido e é cerca de $1,56.10^{-4}$; a razão medida para os três cometas é duas vezes esse valor (Robert, 2001). Esses corpos celestes são oriundos da nuvem de Oort e talvez cometas com origem em regiões menos distantes, como o cinturão de Kuiper, possam apresentar uma composição comparável à encontrada nos oceanos terrestres. Logo, o processo migratório de corpos formados em regiões além da snow line pode ter desempenhado um papel importante na origem e evolução da vida na Terra, além de fornecer indícios para a existência de exoluas orbitando exoplanetas gigantes.

\subsection{Estrelas da Sequência Principal}

As estrelas desempenham um papel de extrema importância ao se definir as condições de habitabilidade dos sistemas planetários e, nesse sentido, será feita aqui uma breve introdução das principais caracterísitcas físicas desses objetos. De antemão, dar-se-á ênfase às estrelas que estão localizadas na Sequência Principal $(S P)$ que são as mais interessantes do ponto de vista astrobiológico e alvo desta pesquisa.

Assumindo, com uma aproximação razoável, que as estrelas possuem comportamento muito similar a de um corpo negro, ou seja, obedecem a lei de Planck equacionada como:

$$
B_{\nu}(T)=\frac{2 h \nu^{3}}{c^{2}} \frac{1}{e^{\frac{h \nu}{k T}}-1}
$$

a temperatura efetiva de uma estrela pode ser definida. Logo, esta definição ocorrerá de tal forma que o fluxo total da estrela seja equivalente ao calculado pela lei de Planck, 
possuindo uma relação direta com a temperatura efetiva estelar:

$$
S=\pi B(T)=\pi B_{\nu}(T) d \nu=\sigma T_{e f f}^{4}
$$

Sendo $\sigma$ a constante de Stefan-Boltzmann e considerando as estrelas como objetos esféricos de raio $R$, pode-se escrever uma equação para a luminosidade estelar:

$$
L(t)=4 \pi R^{2} \sigma T_{e f f}^{4}
$$

As estrelas podem ser classificadas de diferentes maneiras e o esquema de classificação mais intuitivo é através da utilização do diagrama proposto por Hertzsprung-Russell, conhecido como diagrama $H R$. Este diagrama consiste em um gráfico da luminosidade estelar em função de sua temperatura efetiva (figura $1.5^{4}$ ).

Teorias modernas demonstram que as estrelas evoluem com o tempo e essa evolução fica bem evidenciada durante a observação do diagrama $H R$, pois constata-se que há uma região com um acúmulo de estrelas, composta por objetos de evolução lenta e regiões relativamentes vazias, preenchidas por objetos de evolução rápida. O diagrama $H R$ é atravessado por uma longa "diagonal", conhecida como Sequência Principal, onde estão localizadas a maioria das estrelas e, entre elas, o Sol. Acima e abaixo da Sequência Principal, encontram-se estrelas de alta e baixa luminosidade respectivamente. A evolução estelar, considerando-se que a estrela já esteja localizada na Sequência Principal (com reações nucleares desencadeadas na região central), dependerá essencialmente de sua massa. Caso o fragmento da nuvem molecular possua massa inferior a $0,08 M_{\odot}$, não haverá início das reações nucleares e a estrela não se formará; assim, estes objetos formarão planetas ou brown dwarfs (anãs marrons).

A energia produzida pelos núcleos estelares durante sua evolução é transportada em direção ao espaço por dois processos distintos: a convecção (circulação de fluidos) e a difusão radiativa (radiação eletromagnética). Essa energia dissipada é utilizada pela biosfera de planetas habitáveis e permite a ocorrência de vários processos físico-químicos essenciais ao desenvolvimento da vida, dentre os quais, o processo da fotossíntese, responsável pela transição da atmosfera primitiva rica em dióxido de carbono para a atual, onde a concentração de oxigênio é expressiva.

\footnotetext{
${ }^{4}$ A figura pode ser acessada em: http://www.atlasoftheuniverse.com/hr.html. Acesso em: 24/07/2012.
} 


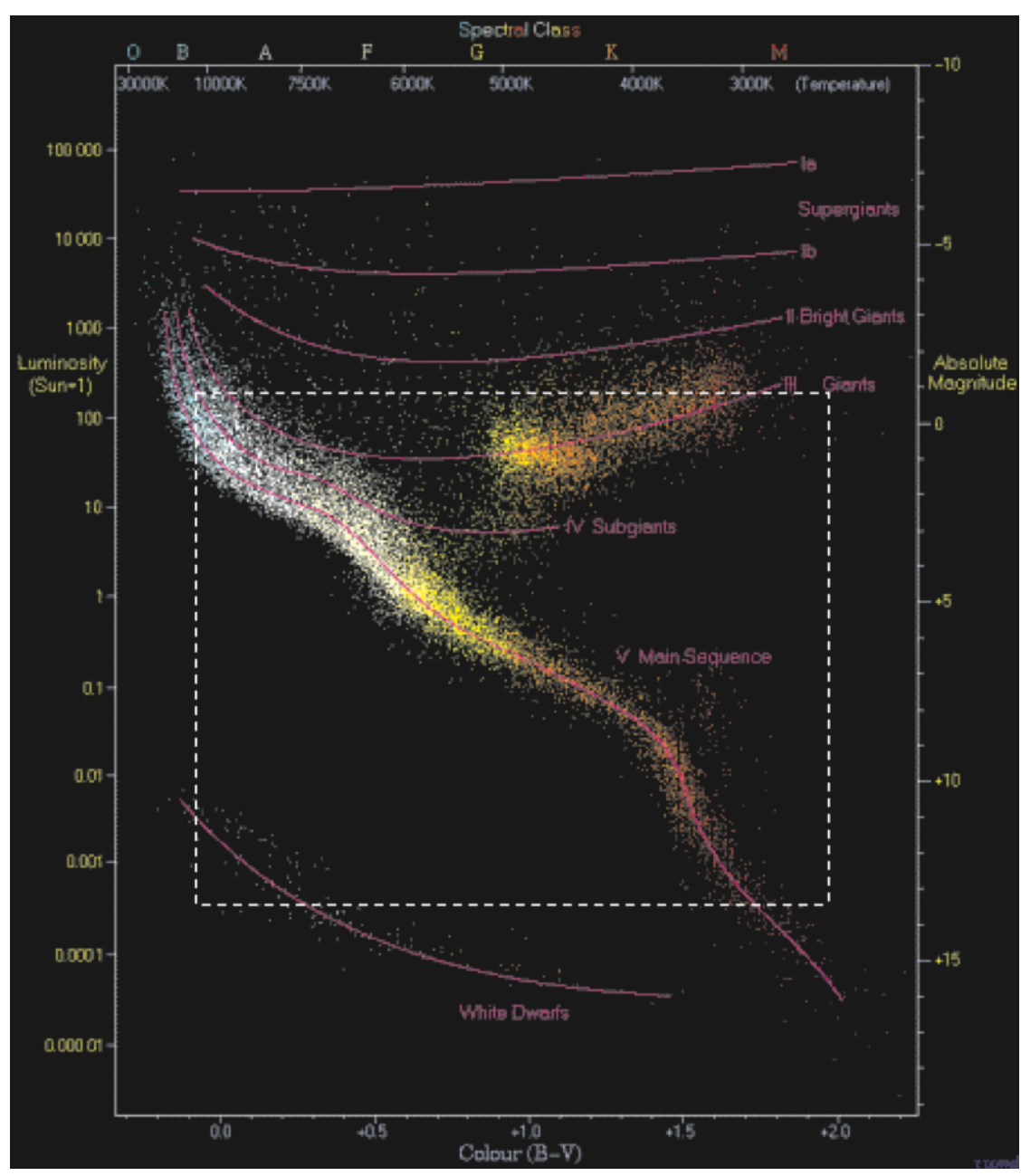

Figura 1.5: Diagrama Hertzsprung-Russel. Fonte: Powell (2009).

Estrelas de baixa massa, ao evoluírem, passam pelo estágio de nebulosa planetária e se transformam em objetos extremamente quentes de dimensões comparáveis a da Terra, sendo classificadas como estrelas anã brancas. Já as estrelas massivas, com massas aproximadamente $M_{s} \geq 8 M_{\odot}$ evoluem e podem sofrer uma explosão conhecida como supernova. Se a massa de seu núcleo for menor ou igual a $3 M_{\odot}$, transformam-se em estrelas de nêutrons altamente compactas, com raios da ordem de $10 \mathrm{~km}$, ou tornam-se buracos negros, caso a massa nuclear ultrapasse o valor de $3 M_{\odot}$.

Estrelas localizadas na Sequência Princial, transformam hidrogênio em hélio por meio de reações nucleares em seu centro. Neste processo há combinação de quatro prótons para formação de um núcleo de hélio e, logicamente, uma liberação de energia, que é estimada ser da ordem de 0,03 $m_{p} c^{2}$, ou seja, 0,007 da energia original (4 $m_{p} c^{2}$ ) (Padmanabhan, 
2001, p. 15). A escala de tempo de permanência na Sequência principal é diretamente proporcional à massa e inversamente proporcional à luminosidade da estrela sendo que tal luminosidade pode ser aproximada como $L \propto M^{n}$, com $n$ variando de 3 a 4 (Maciel, 1999, p. 28). Logo, o tempo de permanência de uma estrela na Sequência Principal vai ser inversamente proporcional à sua massa:

$$
t_{s p} \sim 10^{10}\left(\frac{M_{s}}{M_{\odot}}\right)^{1-n}
$$

Nota-se, portanto, que estrelas massivas vão consumir seu hidrogênio mais rapidamente (aproximadamente poucos milhões de anos) do que as estrelas menos massivas (aproximadamente 10 bilhões de anos para estrelas do tipo solar), obviamente, permanecendo um tempo menor na Sequência Principal.

Após as estrelas de baixa massa sairem da Sequência Principal haverá um aumento da temperatura central e consequente aumento em tamanho (provável destino de estrelas do tipo solar). Em seguida, reações termonucleares ocorrerão com a queima do hélio e conversão do interior estelar em carbono e oxigênio, com contínua expansão do envelope (nebulosa planetária). Este cenário, certamente desencadeia a aniquilação de todos os componentes de um possível sistema planetário. Após o estágio de nebulosa planetária, estrelas do tipo solar sofrem um processo de encolhimento do núcleo (core) e se tornam objetos muito quentes (aproximadamente $100000 \mathrm{~K}$ ), pouco luminosos e com o tamanho comparável a de planetas, corpos conhecidos como estrelas anãs brancas (Whitedwarf), que esfriaram lentamente em centenas de bilhões de anos. Estágios de evolução estelar pós Sequência Principal não são interessantes para estudos relacionados à Astrobiologia.

O estudo da habitabilidade em sistemas planetários está intimamente relacionado com a luminosidade da estrela central, já que os limites das Zonas Habitável e Extremófila sofrerão deslocamentos devido ao aumento desse parâmetro. Para simular a evolução da luminosidade estelar em função do tempo foram utilizados os estudos conduzidos por Gough (1981), que a partir de seu modelo de evolução estelar obteve uma equação que descreve a evolução de tal parâmetro em um intervalo de tempo de $t \leq t_{\odot}$, sendo que $t_{\odot}$, refere-se à do Sol (aproximadamente 4, 8 bilhões de anos) e $L_{\odot}^{\text {presente }}$, a luminosidade Solar atual: 


$$
L^{\text {passado }}(t)=\left[1+\frac{2}{5}\left(1-\frac{t}{t_{\odot}}\right)\right]^{-1} L_{\odot}^{\text {presente }}
$$

Entretanto, pode-se expandir esse limite de tempo utilizando a interpolação proposta por Turck-Chieze et al. (1988), com $t_{\odot}<t<10$ G anos:

$$
L^{\text {futuro }}(t)=\left[5,59 \operatorname{Ganos} \frac{1}{t}-1,39+0,26 \operatorname{Ganos}^{-1} t\right] L_{\odot}^{\text {presente }}
$$

Como o objetivo central deste trabalho é estudar as condições de habitabilidade em sistemas planetários extrasolares, deve-se ainda utilizar a relação massa-luminosidade proposta por Kippenhahn e Weigert (1990) (válida apenas para estrelas localizadas na Sequência Principal) somada a uma relação de scaling apropriada para que se possa descrever a luminosidade de estrelas distintas do Sol:

$$
\begin{gathered}
L \sim M^{3,88} \\
L_{\text {estrela }}=L_{\odot}\left(\frac{M_{\text {estrela }}}{M_{\odot}}\right)^{3,88}
\end{gathered}
$$

Assim, tem-se as principais ferramentas matemáticas necessárias à razoável descrição dos processos inerentes à evolução estelar, que podem influenciar no desenvolvimento de organismos em sistemas planetários extrasolares, assim como a tectônica de placas, o vulcanismo, os impactos de meteoritos, etc.

\subsection{Terra Primitiva e Vida}

Todo o material biológico encontrado na Terra é constituído por cerca de vinte elementos químicos diferentes, sendo o mais importante o carbono, seguido pelo nitrogênio, oxigênio e fósforo, além do hidrogênio. A origem da maioria desses elementos químicos é a nucleossíntese estelar, processo que ocorre no interior de estrelas onde o elemento primordial $H$ é transformado em $H e$ e depois em $C, N, O$ e outros elementos pesados.

Entretanto, apesar do conhecimento científico atual ser capaz de identificar a origem dos elementos químicos necessários ao desenvolvimento da vida, ele pouco informa a respeito de quais foram as condições necessárias ao início dela. Questões versando sobre quando surgiu o primeiro ser vivo e qual a sua origem permanecem longe de serem respondidas. A 
dificuldade está no fato de que se dispõe de poucas informações confiáveis sobre o ambiente terrestre primordial, ou seja, não é sabido ao certo qual era a composição da atmosfera primitiva, a extensão dos oceanos e a temperatura superficial do planeta.

Logo após a formação completa da Terra, por volta de 4, 5 bilhões de anos, as condições do planeta eram hostis para o desenvolvimento da vida. Erupções vulcânicas e bombardeamentos de corpos externos provavelmente extinguiram formas de vida que tenham surgido nessa época. A fase de bombardeamento pesado (late heavy bombardment) terminou por volta de 3,8 bilhões de anos como pode ser observado na figura 1.6, na qual Zahnle et al. (2007) demonstram de forma condensada algumas possíveis hipóteses propostas para a explicação desse período. Algumas estruturas identificadas como fósseis e dados de fracionamentos isotópicos, interpretados como evidência de atividade fotossintética (resíduo de clorofila), levaram alguns cientistas a afirmarem que a vida já existia há 300 milhões de anos antes do fim do período de bombardeamento pesado (Mojzsis et al., 1996).

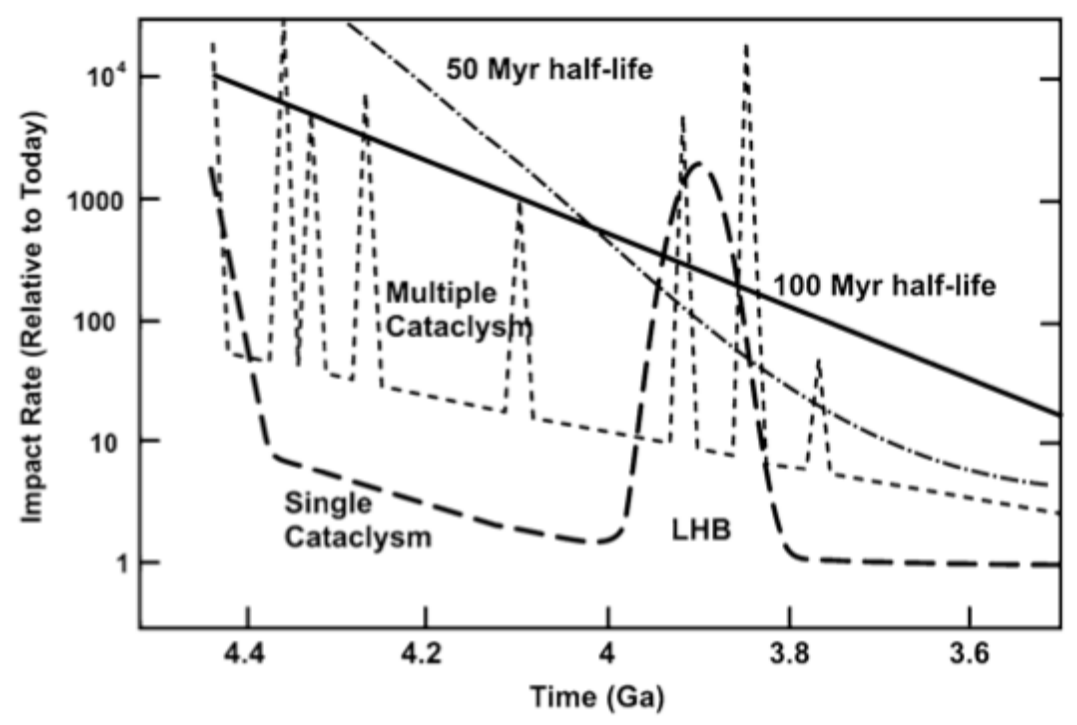

Figura 1.6: Late Heavy Bombardment. Na figura são mostradas as interpretações do período de bombardeamento pesado obtidas através de dados lunares. Processos contínuos a 50 milhões de anos (Wilhelms, 1987); 100 milhões de anos (Neukum et al., 2001); cataclismas simples (Rider 2002, 2003); cataclismas múltiplos (Tera et al., 2007). Fonte: Zahnle et al., 2007.

Observações astronômicas de nuvens moleculares (Buhl, 1971), locais onde há formação de sistemas planetários e moléculas complexas, aliadas a simulações laboratoriais das condições da Terra primitiva, sugerem que a vida possa ter surgido em nosso planeta como resultado de sínteses abióticas e interações com corpos extraterrenos, como cometas 
e meteoritos, que carregam consigo compostos orgânicos e moléculas simples como o $H C N$. No início do século $X X, \mathrm{~S}$. Arrhenius sugeriu que a vida terrestre poderia ser de origem extraterrestre. A sua hipótese era baseada no fato de que a vida poderia ter chegado a Terra na forma de esporos microscópicos transportados através da ação da pressão de radiação das estrelas, ideias estas, que ficaram conhecidas como a hipótese da panspermia.

Em 1924, o bioquímico russo Aleksandr Ivanovich Oparin, influenciado pelos estudos de Charles Darwin, propôs a hipótese heterotrófica ${ }^{5}$ da origem da vida. A teoria de Oparin afirmava que os primeiros organismos a habitarem o planeta eram heterótrofos anaeróbicos que se formaram e obtiveram energia a partir de compostos orgânicos sintetizados e acumulados nos mares da Terra primitiva, configurando um cenário que é conhecido atualmente como "sopa"prebiótica.

Entretanto, somente em 1953 é publicado o artigo do jovem cientista Stanley L. Miller que descrevia a tentativa de reprodução das ideias propostas por Oparin em laboratório. Miller havia submetido a descargas elétricas uma mescla de gases formada por metano, amoníaco, hidrogênio e vapor de água, a qual acreditava ser uma simulação coerente das condições primitivas atmosféricas da Terra. Miller pôde observar por meio de seu experimento a formação de aminoácidos, hidroácidos, uréia e outras moléculas de interesse químico e pré-biótico. Neste mesmo ano, os cientistas Francis Crick, James Watson e Maurice Wilkins, apresentaram o modelo de dupla hélice do DNA.

Já em 1960, Joan Oró demonstrou que a condensação de cinco moléculas de $H C N$, molécula formada no experimento de Miller, presente em nuvens interestelares e nos núcleos de cometas, formava uma das bases nitrogenadas (adenina) presente nas moléculas de DNA, RNA e ATP, de extrema importância ao metabolismo dos seres vivos. Ao longo do tempo, vários cientistas seguindo os estudos de Miller e Oró conseguiram sintetizar, além de bases nitrogenadas, açúcares, lipídios e outras moléculas de interesse biológico. Todos estes estudos aliados à possível facilidade em fazer chegar a Terra o matérial orgânico de origem não biológica por meio de cometas, meteoritos e asteróides, favorecem o cenário de evolução proposto por Oparin. Entretanto, a dúvida ainda permanece: a vida realmente pode ter surgido a partir da sopa primitiva contaminada por material orgânico de origem

\footnotetext{
${ }^{5}$ Segundo Oparin, no início, a Terra foi povoada por organismos simples, denominados heterotróficos, ou seja, aqueles que não possuem a capacidade de produzir seu próprio alimento.
} 
extraterrestre?

Atualmente existem fortes objeções contra os argumentos da teoria de Oparin e seus seguidores. Estes argumentos estão baseados no fato de que provavelmente a Terra primitiva não apresentava uma atmosfera redutora, ou seja, sua constituição não consistia predominantemente de moléculas como o $\mathrm{NH}_{3}$ e o $\mathrm{CH}_{4}$, mas provavelmente por $\mathrm{CO}_{2}, \mathrm{CO}$ e $\mathrm{N}_{2}$. Esta composição não redutora da atmosfera é baseada no fato de que erupções vulcânicas contribuíram para a emissão de gases como $\mathrm{CO}$ e $\mathrm{CO}_{2}$, além de que a própria interação da radiação UV solar com moléculas como o $\mathrm{NH}_{3}$ e o $\mathrm{CH}_{4}$ - a radiação solar ocasiona a fotólise da água, gerando o radical $\mathrm{OH}$ que ataca o metano, produzindo $\mathrm{CO}_{2}$ e hidrogênio molecular - não favorece a existência destas por longos períodos. Kasting (1993) sugere que a atmosfera terrestre primitiva era fracamente redutora e composta por uma mistura de $\mathrm{CO}_{2}, \mathrm{~N}_{2}$, e $\mathrm{H}_{2} \mathrm{O}$ combinada com pequenas quantidades de $\mathrm{CO}$ e $\mathrm{H}_{2}$. Este cenário promoveu um eficiente efeito greenhouse, induzido pelas altas concentrações de dióxido de carbono e responsável por compensar a baixa luminosidade solar (faint young Sun).

A vida primitiva na Terra provavelmente surgiu na água e foi capaz de realizar processos químicos, transmitir informação por meio de suas moléculas e evoluir. Porém, não se sabe ao certo qual foi a molécula primordial responsável por essa evolução: alguns defendem que esta molécula seria o DNA, capaz de se replicar e armazenar informação. Outros acreditam serem as proteínas, pois essas são catalizadoras de reações químicas e indispensáveis à replicação dos próprios ácidos nucleicos. Uma possibilidade distinta das anteriores surge quando Thomas Cech e Sidney Altman observaram que o RNA, além de armazenar informação genética, também possuía atividade enzimática, ou seja, catalizava diversas reações bioquímicas. As proteínas, assim como as moléculas de DNA, são mais estáveis que a molécula de RNA. Caso seja verdadeira a hipótese de que a molécula de RNA seja a precursora das proteínas e do próprio DNA, outro impasse surge: se as atividades catalíticas e replicadoras da molécula de RNA dificilmente puderam encontrar condições ideais para se desenvolver nos mares primitivos, qual a origem dessa molécula? A resposta a este questionamento ainda é incerta, porém se argumenta que algum processo químico ainda não conhecido tenha facilitado seu surgimento ou que o próprio RNA seja uma molécula produto da evolução da biosfera, tendo sua origem ligada a moléculas desconhecidas, capazes de armazenarem informações genéticas. Na figura 1.7 é apresentada a 
evolução da vida baseada no RNA ribossômico.

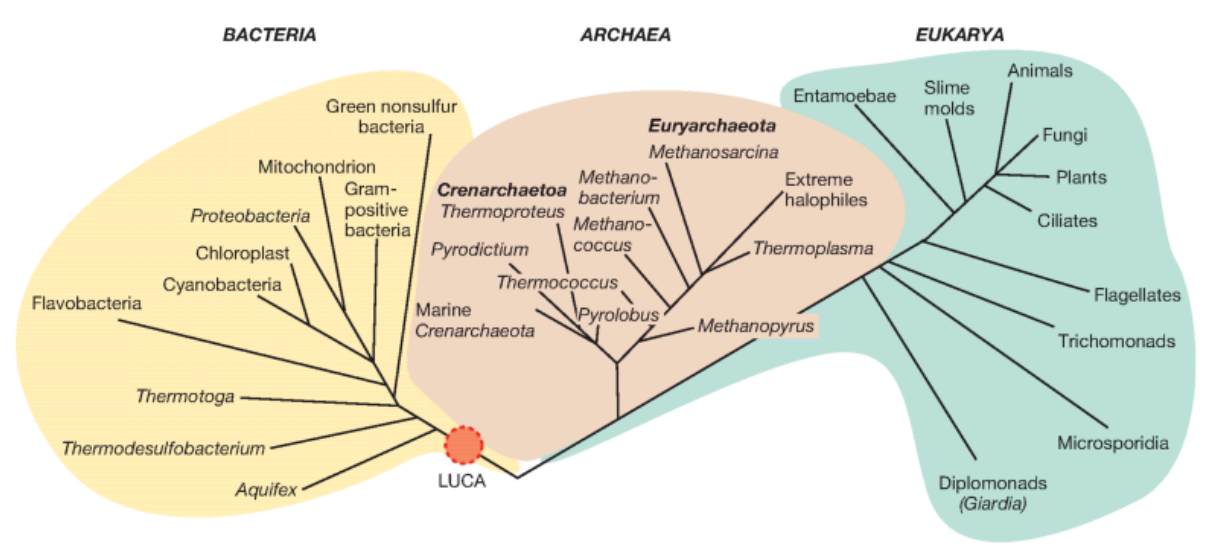

Figura 1.7: Árvore filogenética da vida baseada no sequenciamento do RNA ribossômico. Fonte: Madigan et al. (2012), p. 36.

Se a tentaiva de compreensão dos processos que podem ter levado ao surgimento da vida é uma tarefa complexa, definir o seu significado também o é. A vida na Terra pode ser dividida em três principais domínios, que evoluíram provavelmente a partir de um ancestral comum: bactérias, arqueas e eucárias. Dentro dos domínios das bactérias e arqueas, estão as células microscópicas de organização procariótica, isto é, células que não possuem núcleo e organelas, mas que exibem metabolismos diversos. O domínio das eucárias é formado por organismos unicelulares (protistas) e pluricelulares (plantas, fungos e animais), constituídos por células providas de núcleos, membranas, organelas e citoesqueleto.

Nota-se que a unidade mínima da vida é a célula. Logo, a vida pode ser entendida como um conjunto de processos químicos que ocorre dentro de um compartimento, a célula, local onde há trocas de energia e matéria com o meio exterior, processos metabólicos, reprodução através da transferência de material genético e evolução via seleção natural. A compreensão, mesmo que incompleta, da definição de vida e dos parâmetros necessários para identificá-la é de grande importância aos estudos da Astrobiologia, focalizados na procura de vida além dos ambientes terrestres. 
Capítulo 2

\section{Exoplanetas}

Após séculos de especulações, a descoberta dos primeiros planetas fora do Sistema Solar em torno de um pulsar (Stevens et al., 1992) e de uma estrela da Sequência Principal (SP) (Mayor e Queloz 1995) abriu uma nova era de consequências múltiplas na Astronomia e ciências afins. Apesar das limitações experimentais (Udry e Santos, 2007), foram descobertos até julho de 2012, 776 planetas com $M<20 M_{\text {Jupiter }}$ orbitando outras estrelas (vide catálogo de J. Schneider http://exoplanet.eu/) e esse número cresce regularmente. As características orbitais, as dimensões dos exoplanetas e a análise de suas estrelas centrais provocaram uma intensa revisão nas teorias de formação e migração planetária, estimulando o surgimento de novos temas de pesquisa, como por exemplo, a possível infuência da composição química das estrelas na ocorrência de planetas em torno delas e a relação dessa composição com a do envelope circunstelar primitivo (Santos et al., 2003; Fischer et al., 2004; Marcy et al., 2005). Essa última terá infuência decisiva no eventual aparecimento de vida nos planetas do sistema.

A maioria dos exoplanetas conhecidos foi detectado via efeito Doppler, pela medida da perturbação gravitacional causada por eles em suas estrelas centrais, técnica conhecida na astronomia por velocimetria radial. A amostra disponível apresenta, portanto, um forte viés descrito pela Lei de Newton da precisão que se consegue alcançar atualmente em medidas de velocidade radial e do fato de que é preciso coletar observações ao longo de pelo menos um período orbital: descobriu-se sobretudo, uma grande quantidade de planetas massivos e/ou mais próximos das estrelas centrais. Quando se dispõe também de observações de trânsitos fotométricos dos planetas, há possibilidades de medir suas massas e raios (Fressin et al., 2007). Com o lançamento dos satélites CoRoT em dezembro de 
2006 (Convection, Rotation and Planetary Transits, vide http://corot.oamp.fr/) e Kepler (www.kepler.nasa.gov/), o número de exoplanetas descobertos via trânsitos aumentará de uma ordem de grandeza nos próximos anos.

Um dos campos científicos que a descoberta dos exoplanetas mais tem estimulado é o da Astrobiologia: a constatação de que a existência de sistemas planetários é um fato corriqueiro na Galáxia reforçou sobremaneira o conceito lógico/intuitivo de que a vida poderá ser um fenômeno comum fora da Terra e de que ela pode até mesmo ter sido originada antes.

\subsection{Breve Histórico}

Giordano Bruno (1548 - 1600), sacerdote católico queimado vivo em uma fogueira em 17 de fevereiro de 1600, havia dito em 1584: "Existem inúmeros Sóis e inúmeras Terras, todas elas girando em torno de seus Sóis, da mesma forma que os sete planetas de nosso sistema. Só vemos os Sóis, pois são corpos grandes e luminosos, mas seus planetas são invisíveis por serem pequenos e pouco luminosos. Os inúmeros mundos do Universo não são piores e nem estão mais desabitados que nossa Terra ".

Quase 400 anos após a morte de Giordano Bruno surgiram as primeiras comprovações científicas acerca da existência de planetas além do Sistema Solar (Exoplanetas). Em 1992, planetas foram detectados em torno de um pulsar (Stevens et al., 1992). Em 1995, a descoberta de um planeta, orbitando uma estrela da Sequência Principal, denominado 51 Pegasi foi anunciado por Mayor e Queloz (Mayor e Queloz, 1995). Este foi o primeiro sistema planetário extrasolar a ser identificado e, logo em seguida, em 1998, uma equipe americana anunciou também a descoberta de aproximadamente uma dúzia de novos candidatos (Marcy e Butler, 1998). Nestes casos, variações nas velocidades radiais estelares indicaram a presença de planetas do tipo Hot Jupiters. A quantidade de exoplanetas confirmados cresceu de forma acelerada desde 1995, e com eles ressurge a intrigante questão: há planetas capazes de oferecer condições mínimas para que a vida possa se desenvolver? 


\subsection{Métodos de Detecção}

Observar diretamente um exoplaneta, ou seja, detectar fótons provenientes diretamente de um determinado planeta fora do Sistema Solar é uma tarefa muito difícil. Esta dificuldade é devido à relação de brilho entre a estrela central do sistema e seus possíveis planetas. Se o Sistema Solar fosse observado de uma distância de dez parsecs ${ }^{6}$, o Sol seria aproximadamente um bilhão de vezes mais brilhante que um planeta em sua proximidade para comprimentos de onda correspondentes à faixa da região visível do espectro eletromagnético. Se esta observação fosse feita na região infravermelha do espectro eletromagnético, o Sol se apresentaria um milhão de vezes mais brilhante que esse planeta (Marais et al., 2002). A figura 2.1 mostra o argumento exposto acima.

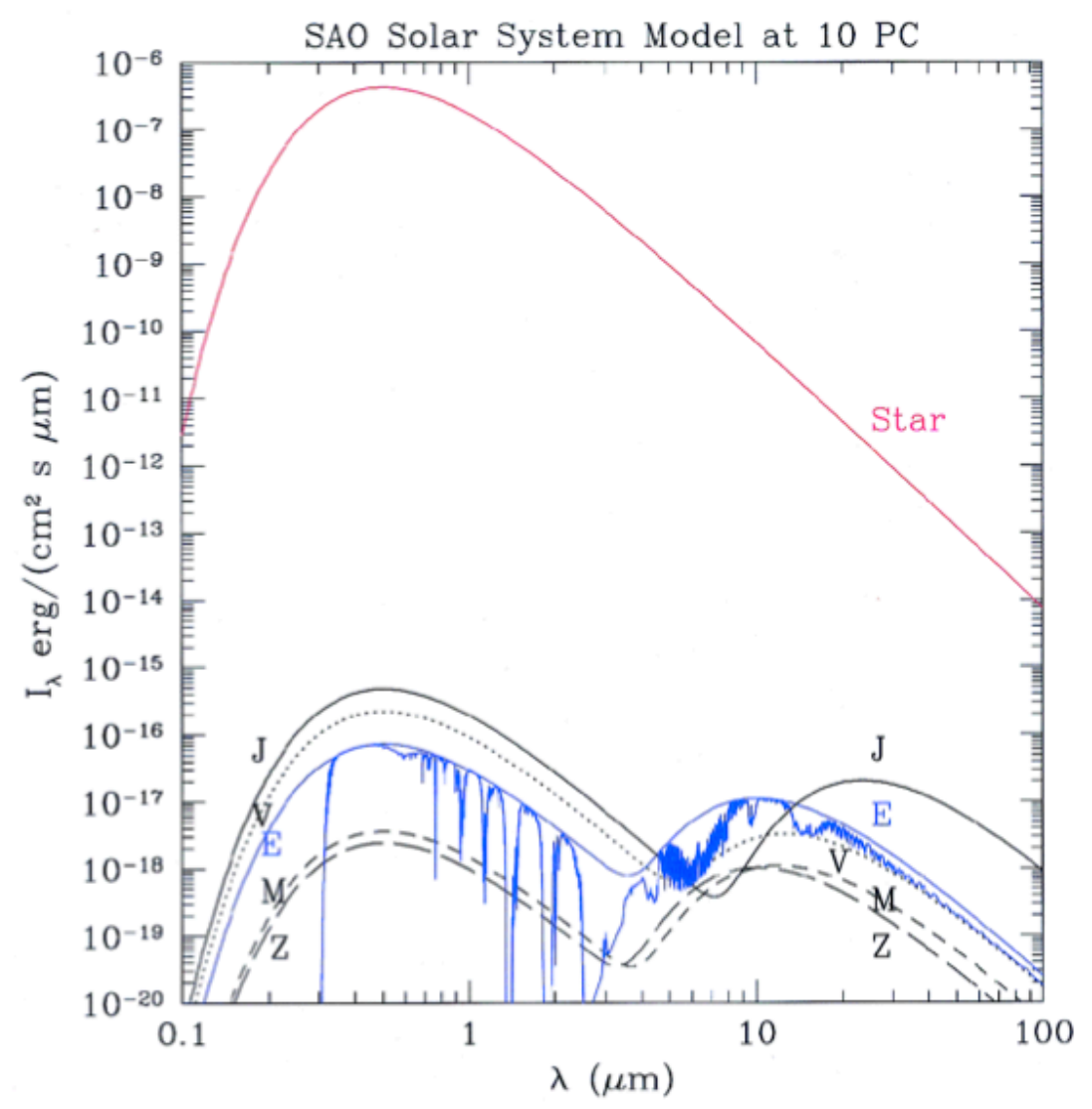

Figura 2.1: Modelo espectral representativo do Sol e seus planetas, observados a uma distância de dez parsecs. Fonte: Marais et al., 2002.

Tal exemplo deixa claro que até mesmo planetas massivos não seriam detectados e

\footnotetext{
${ }^{6} 1$ parsec $\sim 3,1.10^{16}$ metros.
} 
além disso, aponta para uma hipótese não verdadeira, a de que no sistema não há planetas orbitando a estrela central. Logo, concluí-se que métodos indiretos devem e têm sido usados preferencialmente na procura por exoplanetas. No entanto, o avanço de técnicas e das tecnologias pode alterar o cenário atual.

\subsubsection{Velocidade Radial (Método Doppler)}

Toda estrela hospedeira irá experimentar um deslocamento devido à atração gerada pelo campo gravitacional do exoplaneta que descreve um movimento ao seu redor. Este movimento em torno do centro de massa do sistema pode ser detectado pela análise das pequenas mudanças nas linhas espectrais estelares devido ao efeito Doppler. O deslocamento Doppler varia periodicamente. Este método tem sido utilizado amplamente e é o responsável pela maioria das descobertas dos exoplanetas catalogados. Logicamente, ele cria um viés pelo fato de que somente os planetas mais massivos e/ou próximos de sua estrela central podem ser detectados. A figura 2.2 ilustra a situação descrita acima.

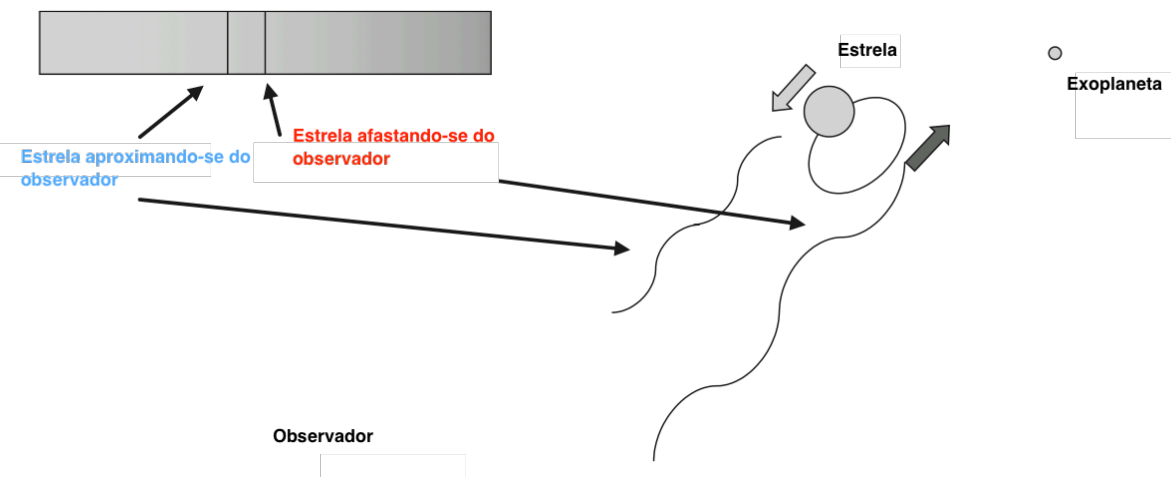

Figura 2.2: Representação esquemática do método de detecção via velocimetria radial.

Ao se considerar um exoplaneta de massa, $M_{p}$, de semi-eixo maior $a_{p}$, em torno de uma estrela de massa $M_{s}$, ambos movendo-se em torno do centro de massa do sistema, sendo que a distância entre a estrela e o centro de massa do sistema $\left(a_{s}\right)$ é pequena, pode-se escrever a igualdade:

$$
M_{s} a_{s}=M_{p} a_{p}
$$

Assumindo, por simplicidade, órbitas circulares, considerando que a velocidade da es- 
trela possa ser aproximada por $v_{s}=\frac{2 \pi R_{s}}{P}$ e aplicando a terceira Lei de Kepler, obtem-se:

$$
v_{s}^{2}=\frac{G\left(M_{s}+M_{p}\right) a_{s}^{2}}{a_{p}^{3}}
$$

Logo, se o $M_{p}<<M_{s}$ e o plano orbital tenha uma inclinação, " $i$ ", com o céu, é possível escrever uma equação para a velocidade radial máxima da estrela:

$$
v_{\text {rad }}^{\text {máx }}=M_{p} \sin (i)\left(\frac{G}{a_{p} M_{s}}\right)^{\frac{1}{2}}
$$

Desse modo, pode-se relacionar a velocidade radial da estrela com o deslocamento Doppler. Entretanto, é notório que para pequenos valores de " $i$ ", tem-se medidas pequenas para a velocidade radial e consequentemente pequenos valores para o deslocamento Doppler. Este fato reduz seriamente a provável detecção de planetas com pequenos valores do parâmetro " $i$ ". Outra complicação inerente ao método é o longo tempo de observação para detectar-se os pequenos deslocamentos Doppler.

\subsubsection{Trânsito Planetário}

O trânsito planetário ocorre quando um planeta atravessa o disco da estrela central de um sistema em uma posição frontal quando observado da Terra. Na realidade, o método consiste em observar a estrela fotometricamente, buscando identificar pequenos desvios na intensidade luminosa que é recebida. Estes desvios podem ser ocasionados por planetas com raios suficientes para causarem um decréscimo da luminosidade da estrela, denunciando a existência deles. Entretanto, o decréscimo da luminosidade será dependente do tamanho do planeta, do tamanho da estrela e também da distância orbital do planeta em relação a estrela e, estas dependências, como já comentadas, acarretarão vieses na amostra dos exoplanetas detectados, já que é mais provável observar trânsitos de planetas gigantes próximos da estrela central.

Através de longos períodos de observação é possível determinar o período orbital do planeta e a presença atmosférica, logicamente, utilizando aparatos espectroscópios que permitam identificar linhas de absorção. Na figura $2.3^{7}$ é ilustrado o decréscimo da luminosidade estelar devido ao eclipse planetário.

\footnotetext{
${ }^{7}$ A figura pode ser acessada em: www.eso.org/public/. Acesso: 01/08/2012.
} 


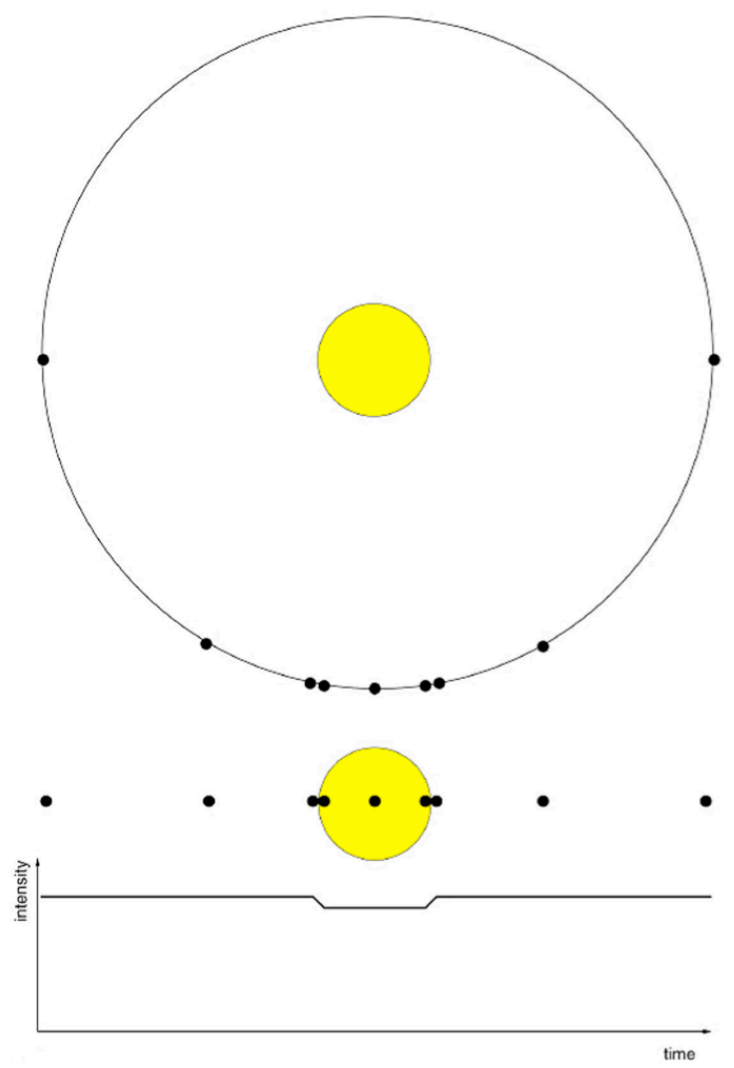

Figura 2.3: Representação do método de detecção através de trânsitos planetários. Observa-se a queda da luminosidade estelar devido ao eclipse planetário. Fonte: ESO (modificado).

Em 2006, foi colocado em órbita o satélite CoRoT (Convection, Rotation and Planetary Transits), cuja principal missão é a busca de exoplanetas por meio do método de trânsito. Em 2009, o telescópio identificou o exoplaneta CoRoT 7b, o primeiro planeta rochoso a ser descoberto por este método.

\subsubsection{Astrometria de Precisão}

Ao se falar sobre métodos de deteç̧ão de exoplanetas por meio de astrometria de precisão fica subentendido a necessidade de se ter dados observacionais referentes à posição estelar muito precisos. O método consiste em analisar a variação da posição da estrela em relação ao seu centro de massa devido à presença de exoplanetas. Esta variação ocorre já que ao se considerar dois corpos com massas distintas, sendo a estrela o que possui a maior massa, ambos vão atrair-se mutuamente. Assim, o centro de massa do sistema estará localizado próximo ao corpo de maior massa, no caso a estrela. Logo, a observação do deslocamento da estrela em relação ao seu centro de massa indicará a presença de um 
objeto, se ele for massivo, ou seja, um provável planeta gigante.

O método favorece a investigação de sistemas com planetas massivos bastante afastados de sua estrela central, localizados a alguns parsecs da Terra. Atualmente, não se dispõe da precisão necessária para a aplicação satisfatória do método. Essa situação deve ser alterada a partir do lançamento da missão GAIA (ESA: Agência Espacial Européia), cujo objetivo é medir distâncias e movimentos de um conjunto formado por aproximadamente $10^{9}$ estrelas, com resolução de $10-20$ micro segundos de arco.

\subsubsection{Microlentes Gravitacionais}

De acordo com a teoria da Relatividade Geral, a luz proveniente de um objeto-fonte pode sofrer alterações devido a sua interação com a massa de outro objeto que se encontre entre essa fonte e o observador. Tal alteração é devido à mudança do brilho aparente do objeto-fonte (ampliação). Um aumento, se provocado por uma estrela que tem a mais um exoplaneta em sua órbita, poderá ser detectado como uma contribuição no efeito de lente esperado, ou seja, será observado na curva de luz um pico secundário como mostra a figura 2.4 .

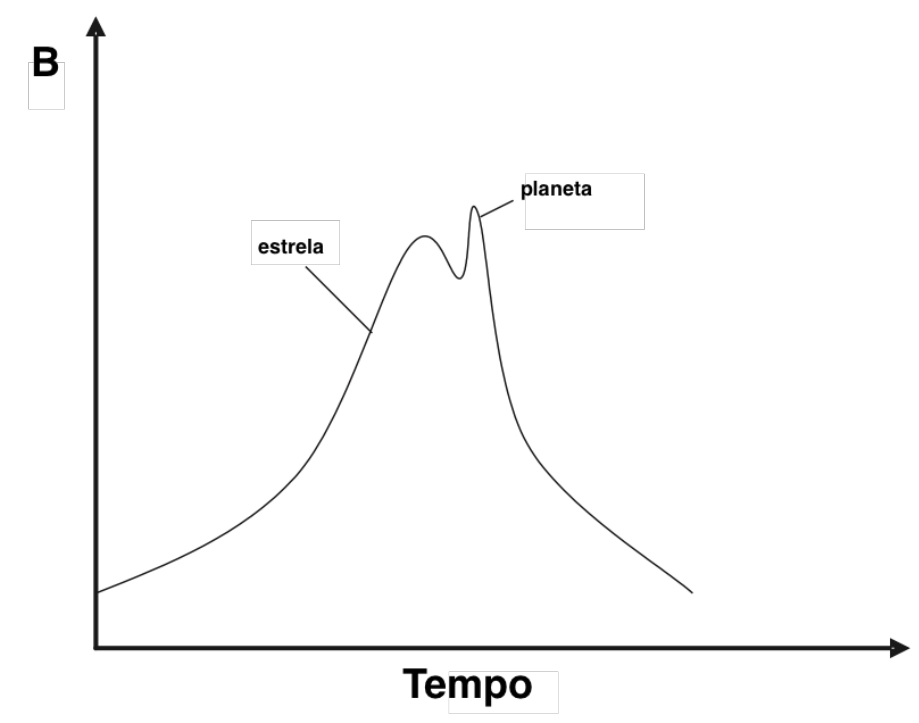

Figura 2.4: Representação do pico adicional à curva de luz estelar quando se utiliza o método de detecção através de microlente gravitacional. Na figura, B representa o brilho aparente do objeto fonte. O segundo pico na curva de luz ocorre devido a presença de um exoplaneta.

A amplificação da luz devido ao efeito de microlente gravitacional é obsevada quando um objeto entra na região delimitada pelo chamado Raio de Einstein: 


$$
\Theta_{E}=\left[\frac{4 G M}{c^{2}} \frac{D_{L S}}{D_{L} D_{S}}\right]^{\frac{1}{2}}
$$

Na equação acima, $D_{L}$ é a distância entre o observador e a lente, $D_{L S}$ a distância entre a lente e a fonte e, $D_{S}$ é a distância entre o observador e a fonte. Poucos exoplanetas foram detectados por esse método devido às dificuldades que se apresentam, como por exemplo, o alinhamento extremamente preciso exigido entre os objetos de estudo.

\subsubsection{Atraso nos Sinais de Pulsares}

Pulsares são estrelas de nêutron em rotação muito rápida. O método consiste na medida de anomalias (atrasos) temporais nos sinais emitidos por tais objetos, que podem ser ocasionados pela presença de exoplanetas, pois se ele for suficientemente massivo, o pulsar mover-se-á em torno do centro de gravidade do sistema. Este método permitiu a detecção do primeiro sistema planetário extrasolar (Stevens et al., 1992). Tal método não é, entretanto, apropriado para buscas de exoplanetas que apresentem condições semelhantes às encontradas na Terra, já que planetas próximos a pulsares dificilmente apresentarão condições necessárias para o desenvolvimento da vida de forma similar a terrestre.

\subsection{Exoplanetas Observados}

A quantidade de exoplanetas identificados tem crescido regularmente como pode ser observado na figura 2.5. Logo, uma análise estatística contendo as principais caracteríticas deles, assim como uma comparação com os planetas presentes no Sistema Solar, é útil. 


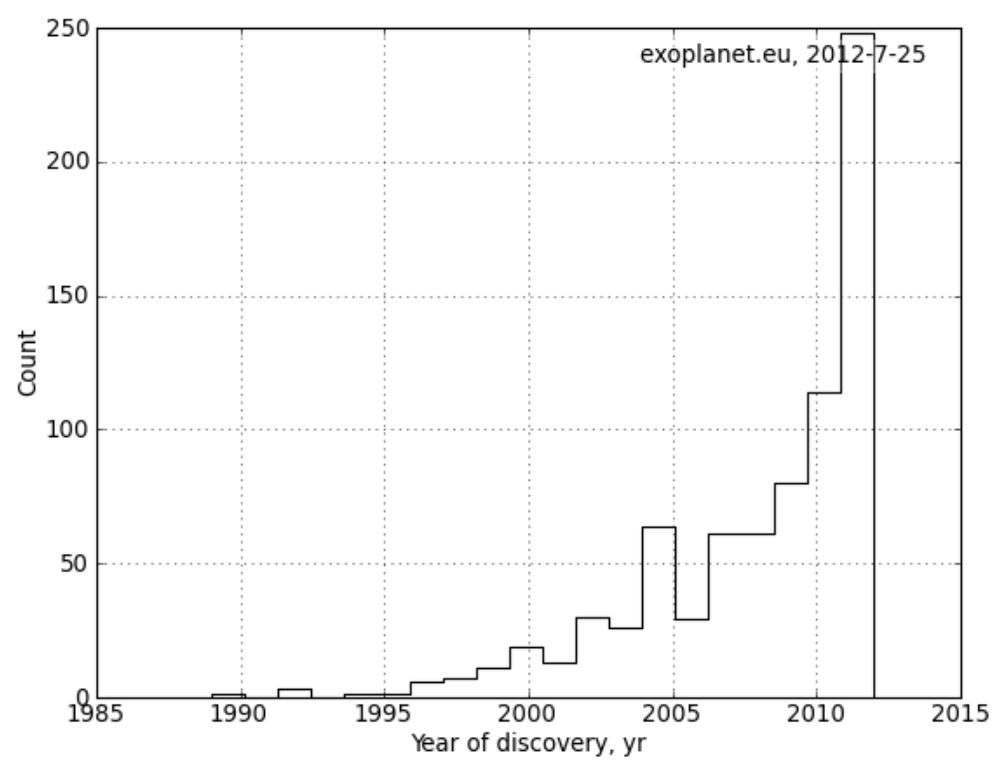

Figura 2.5: Número de exoplanetas descobertos nos últimos anos. Fonte: www.exoplanet.eu.

Como já discutido, os principais métodos de detecção (velocimetria radial e trânsito planetário) utilizados para busca de exoplanetas causam um forte viés nos dados estatísticos desses objetos. Este fato fica claro quando se observa a figura 2.6, através da qual fica evidenciado o predomínio de planetas gigantes, apesar de que atualmente já seja possível por meio dos Satélites CoRoT e Kepler, a detecção de planetas e até mesmo satélites com massas próximas ao valor terrestre. 


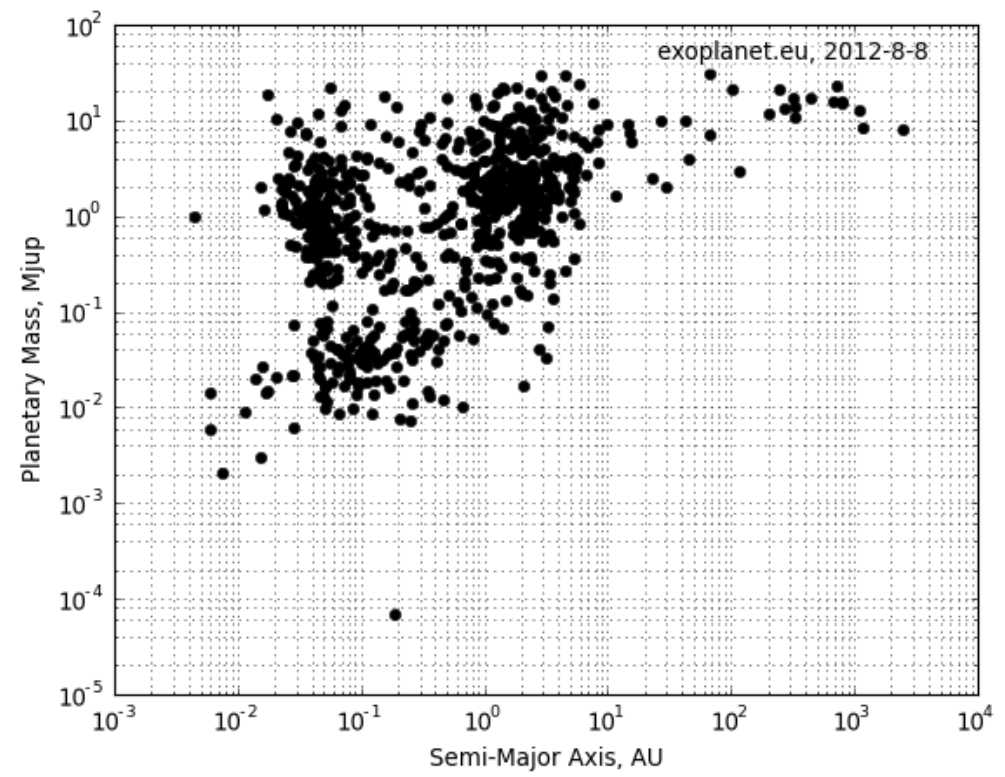

Figura 2.6: Massa dos exoplanetas conhecidos versus o semi-eixo orbital maior. Observa-se o predomínio de planetas massivos. Fonte: www.exoplanet.eu.

A Terceira Lei de Kepler fornece um meio simples para se estimar o semi-eixo maior de uma órbita planetária quando é conhecido o período orbital e há possibilidade de se aferir a massa da estrela hospedeira via medidas espectrais:

$$
P_{\text {orbital }}=2 \pi\left[\frac{a_{p}^{3}}{G\left(M_{p}+M_{s}\right)}\right]^{\frac{1}{2}}
$$

A distribuição dos semi-eixos maiores em função das massas dos planetas catalogados até o momento, assim como a massa e a temperatura de suas estrelas hospedeiras foram apresentadas na figura 1.1 do capítulo 1.

Nota-se que há um grande número de planetas gigantes com massas da ordem de 1 a 5 massas de Júpiter, apresentando valores máximos de semi-eixo orbital muito pequenos (menores que $0,1 U A$ ) e orbitando estrelas com massas iguais ou menores a uma massa solar. Uma análise mais precisa revela hoje que 446 planetas possuem semi-eixos orbitais maiores com valores variando entre 0,01-1UA e, dentre estes, 257 possuem seus eixos dentro de um faixa entre $0,01-0,1 U A$, como pode ser visto na figura 2.7. Porém, nota-se que a quantidade de planetas que apresentam semi-eixos além de $1 U A$ diminui rapidamente, sendo que a maioria deles exibe tais eixos com valores em um intervalo compreendido entre 1,5-2,5UA. Estas constatações podem ser explicadas, aparentemente, tanto por 
fenômenos físicos quanto pelas técnicas observacionais utilizadas; o inesperado cenário, em relação ao Sistema Solar, onde planetas gigantes apresentam períodos orbitais curtos, pode ser explicado por processos migratórios, assunto que será discutido posteriormente.
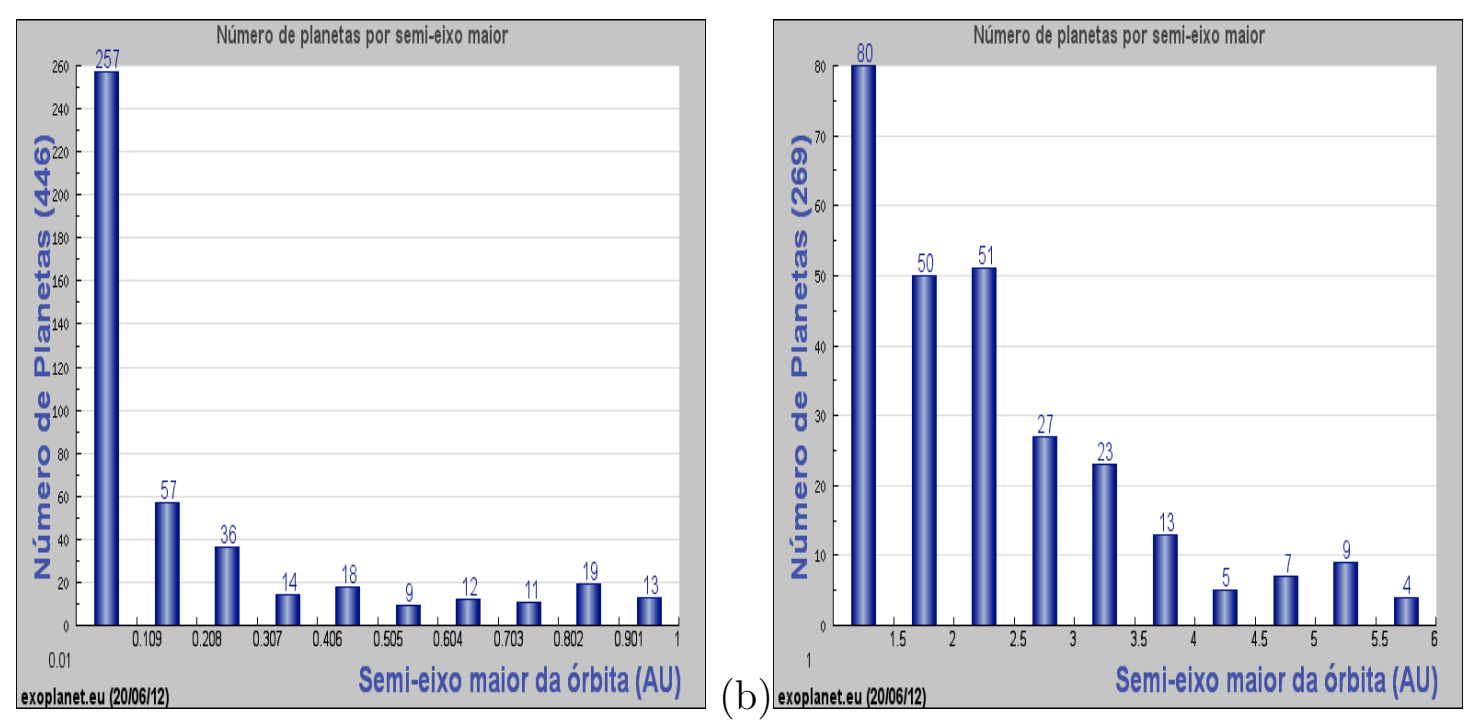

Figura 2.7: Distribuição dos exoplanetas descobertos até o momento. (a): distribuição dos planetas extrasolares em função do semi-eixo orbital maior para um intervalo entre $0,0-1,0 U A$. (b): análise para os planetas com semi-eixos maiores acima de 1,0 UA. Fonte: www.exoplanet.eu.

A análise da distribuição dos valores de excentricidade em função do período orbital dos planetas extrasolares é mostrada na figura 2.8. 


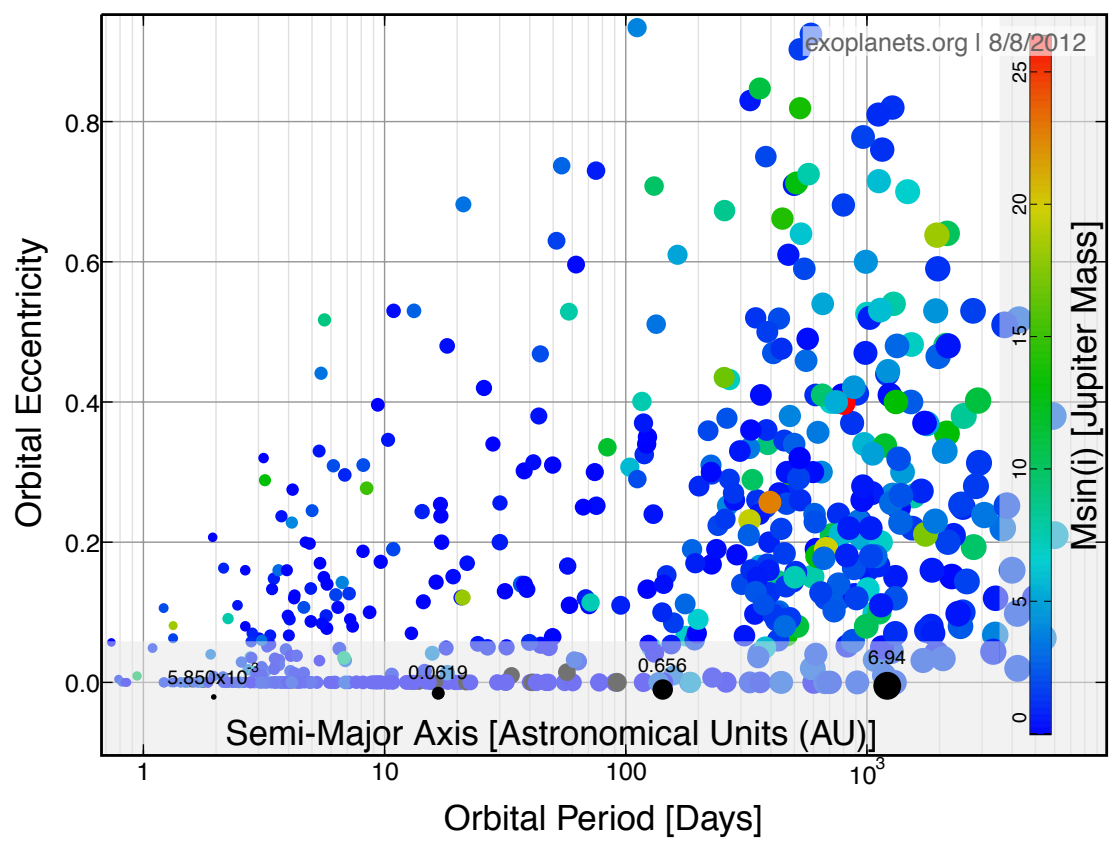

Figura 2.8: Excentricidade versus período orbital dos exoplanetas conhecidos. Observa-se que os planetas próximos de suas estrelas hospedeiras apresentam órbitas circulares. Fonte: Exoplanets Data Explorer.

É fácil notar que objetos com períodos orbitais curtos exibem órbitas praticamente circulares. Entretanto, não parece haver nenhuma correlação entre esses parâmetros ao se considerar planetas com períodos orbitais maiores que poucos dias. Há uma possível explicação para os resultados observados: exoplanetas localizados muito próximos a sua estrela hospedeira experimentam efeitos de maré tão intensos ao ponto de ocorrer dissipação de energia através de fricção do manto planetário, fenômeno ocasionado devido ao torque exercido pela estrela. Essa perda de energia é então a possível responsável pela circularização da órbita planetária (Halbwachs et al., 2005). No Sistema Solar, não há planetas com excentricidade maior que 0,206 (referente a Mercúrio). Apesar do planeta anão Plutão possuir um valor de 0,246 para tal parâmetro, todos os outros planetas do Sistema Solar tem excentricidade abaixo de 0,1 .

É provável que a composição química estelar esteja correlacionada com a formação de planetas em torno delas (Santos et al., 2003; Fischer et al., 2004; Marcy et al., 2005). A metalicidade estelar pode ser definida como o logaritmo da abundância de ferro de uma estrela em relação à abundância de ferro existente no Sol: 


$$
\left[\frac{F e}{H}\right]=\log \left(\frac{F e}{H}\right)_{s}-\log \left(\frac{F e}{H}\right)_{\odot}
$$

Adota-se os valores zero, negativo e positivo para estrelas que possuem metalicidade igual, menor ou maior, respectivamente, ao valor solar. São apresentadas na figura 2.9, as relações entre o semi-eixo maior e a massa máxima dos planetas observados em função da metalicidade das suas estrelas hospedeiras.

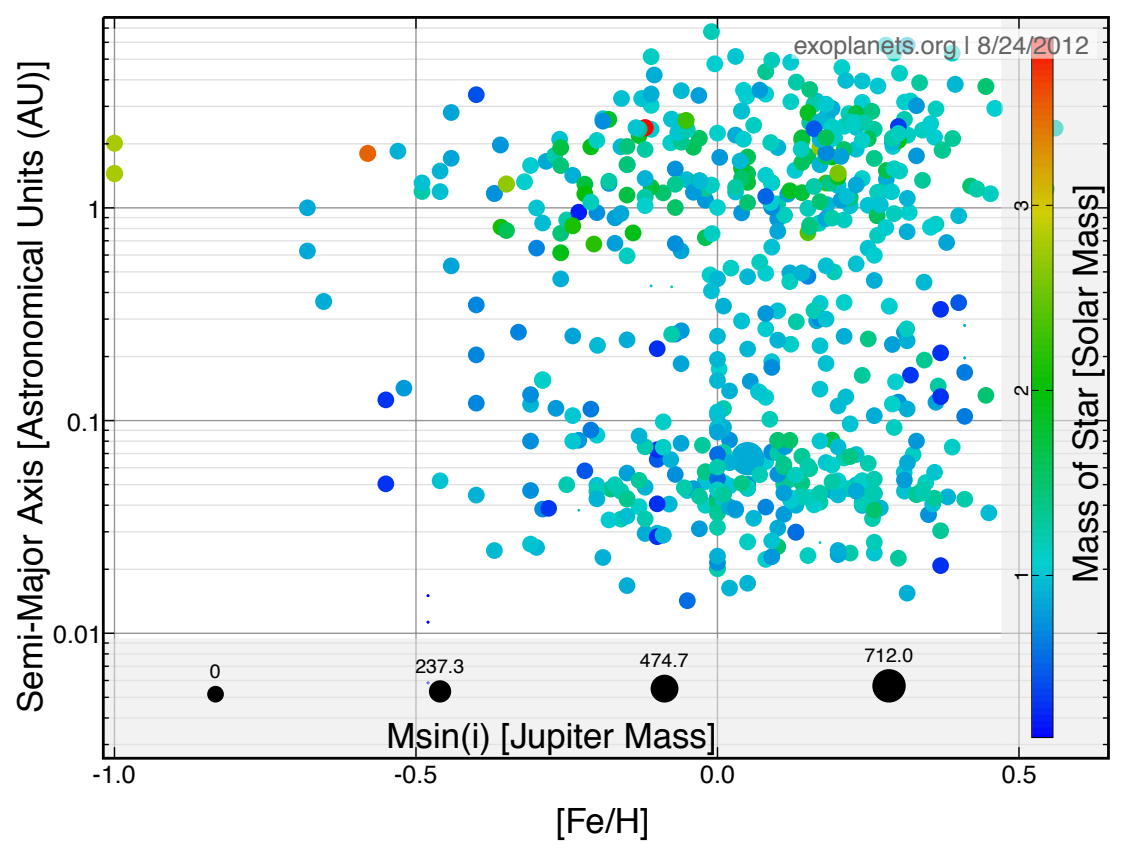

Figura 2.9: Metalicidade estelar versus semi-eixo maior dos exoplanetas conhecidos. Observa-se as massas das estrelas hospedeiras, assim como as dos planetas que as orbitam. Fonte: Exoplanets Data Explorer.

Essa figura mostra que a maioria das estrelas hospedeiras de planetas parece apresentar um excesso nos valores de metalicidade ou valores próximos da solar. Outra constatação importante é a de que sistemas planetários, que abrigam estrelas de alta metalicidade, também podem exibir planetas mais massivos.

\subsection{Taxonomia Planetária}

Pode-se definir com precisão o que é um planeta ou exoplaneta. Baseado na definição da International Astronomical Union (IAU), um corpo celeste só pode ser considerado um planeta (ou exoplaneta) se apresentar órbita ao redor de uma ou mais estrelas, ter 
massa suficiente, porém inferior a treze massas de Júpiter, para que sua auto-gravidade relacionada com as forças de corpo rígido permitam que ele assuma uma forma arredondada (em equilíbrio hidrostático) e tenha a vizinhança livre ao longo de sua órbita. Há ainda os chamados planetas anões (dwarf planets), como Plutão, que apresentam todas a características que definem um planeta, porém não possui a vizinhança limpa ao longo de sua órbita.

No entanto, objetos com massas superiores ao limite imposto para a classificação de um corpo como planeta também são encontrados. Estes objetos não são realmente estrelas, mas possuem massas superiores as dos exoplanetas e são chamados de anãs marrons (Burrows et al., 1997). As anãs marrons diferem dos exoplanetas por executarem o ciclo de ignição nuclear do deutério $\left(0,014 M_{\odot}\right)$, que pode durar aproximadamente dez milhões de anos, após o qual ocorre um processo de esfriamento e a transformação destes objetos em corpos rochosos gelados (Chabrier et al., 2000).

Um dos parâmetros mais importantes para o estudo de sistemas planetários extrasolares é relativo à estrutura interna dos objetos que o compõe. Características como densidade, raio e massa de planetas e satélites são informações importantes para que se compreenda as características das zonas de estabilidade e habitabilidade planetárias.

Na tabela 2.1 é apresentada uma classificação simplificada dos exoplanetas, baseada nos valores de suas massas (Stern e Levison, 2002).

Tabela 2.1 - Classificação dos planetas baseado nos valores de suas massas.

\begin{tabular}{cccccccc}
\hline \hline Classificação Planetária & \multicolumn{2}{c}{ Planetas menores, luas e cometas } & \multicolumn{2}{c}{ PlanetasTerrestres (rochosos) } & \multicolumn{2}{c}{ Planetas Gigantes Gasosos } \\
\hline \hline Objetos & Asteróides & Mercurianos & SubTerras & Terras & SuperTerras & Netunianos & Jupiterianos \\
\hline \hline Massa $\left(\mathrm{M}_{\oplus}\right)$ & $0-0,00001$ & $0,00001-0,1$ & $0,1-0,5$ & $0,5-2$ & $2-10$ & $10-50$ & $50-5000$ \\
\hline \hline
\end{tabular}

O próximo passo será fazer uma rápida análise dos planetas, satélites e objetos mais importantes do Sistema Solar, para em seguida apresentar uma classificação dos principais tipos de planetas extrasolares, apontando uma relação que nos forneça a provável razão entre suas massas e seus respectivos raios, determinando assim, suas densidades. 


\subsubsection{Planetas, Satélites e Objetos do Sistema Solar}

O Sistema Solar abriga dois tipos principais de planetas: os formados próximos ao protosol, ditos planetas rochosos ou telúricos (Mercúrio, Vênus, Terra e Marte), e os formados em uma região mais afastada, além da snow line, conhecidos como planetas gigantes (Júpiter, Saturno, Urano e Netuno). Além destes planetas, o Sistema Solar abriga uma enorme quantidade de objetos que são classificados como corpos menores, ou seja, satélites, asteróides, cometas e planetas anões.

Os planetas terrestres apresentam um núcleo central metálico, constituído principalmente por ferro, envolvido por um manto de silicato. Os planetas gigantes gasosos (Júpiter e Saturno) possuem rápida rotação e são oblatos; a densidade deles é bem baixa quando comparada à densidade de planetas terrestres (a densidade média da Terra é de aproximadamente 5, $\left.15 \mathrm{~g} . \mathrm{cm}^{-3}\right)$, com valores próximos à densidade solar média $\left(1,41 \mathrm{~g} . \mathrm{cm}^{-3}\right)$. Como é sabido, a Terra é um corpo rochoso, mas os planetas gigantes gasosos são predominantemente formados por elementos leves (hidrogênio e hélio) e, embora possuam também elementos pesados, não possuem uma superfície sólida rochosa, a não ser em seu núcleo. Netuno e Urano, conhecidos como planetas gigantes de gelo, são compostos principalmente por água, amônia, metano, silicatos e metais, com uma atmosfera constituída por pequenas quantidades de hidrogênio e hélio.

Há uma região no Sistema Solar, denominada cinturão de asteróides, localizada aproximadamente entre as órbitas de Marte e Júpiter, que comporta uma enorme quantidade de corpos irregulares, chamados de asteróides ou planetas menores. Esses corpos são classificados segundo sua constituição como: tipo-C ou asteróides carbonáceos, tipo-S ou asteróides silicosos e tipo-M ou asteróides metálicos. O maior objeto deste cinturão de asteróides e que pertencente à categoria de planeta anão é Ceres. Ceres é um objeto potencialmente importante do ponto de vista astrobiológico, já que provavelmente possui uma superfície constituída por uma mistura de gelo aquoso com minerais hidratados (carbonatos e argilas) (Rivkin et al., 2006). Estudos apontam que Ceres deve possuir um núcleo rochoso e um manto de gelo (Thomas et al., 2005), além de um provável oceano de água líquida coberto por uma camada de gelo (McCord e Sotin, 2005).

Outra região importante do Sistema Solar é o cinturão de Kuiper. Sua extensão abrange uma região que vai da órbita de Netuno (30 UA) até aproximadamente $50 U A$ de distância 
do Sol (Edgeworth, 1943). Os objetos que fazem parte desta região são divididos em duas categorias: a primeira é constituída por objetos em órbitas não influenciadas por Netuno e a segunda formada por objetos que estão presos ao campo gravitacional Netuniano, em razões orbitais precisas. Descoberto em 1930 por Clyde William Tombaugh, o objeto mais conhecido do cinturão de Kuiper, Plutão, foi por muitos anos considerado um planeta. Entretanto, a partir de 2006 foi reclassificado como planeta anão. É sabido que Plutão possui três satélites, Charon, Nix e Hydra, e é constituído principalmente por rocha e gelo. Sua superfície provavelmente é constituída por grande quantidade de gelo de nitrogênio, com leves traços de metano e dióxido de carbono (Owen et al., 1993), constituição também interessante do ponto de vista astrobiológico.

A constatação da existência de cometas apresentando órbitas longas, extremamente elípticas e isotropicamente distribuídas, apontam para a existência de uma região esferoidal (aproximadamente 100000 UA de extensão), denominada Nuvem de Oort (Oort, 1950), fonte destes cometas. Apenas dois objetos pertencentes à Nuvem de Oort foram descobertos: 90377 Sedna e 2000 CR105. A análise do espectro de Sedna, objeto de cor vermelha, sugere a existência de diferentes tipos de gelo em sua superfície: provavelmente gelo de nitrogênio e metano (Barucci et al., 2005), além de gelo de água (Emery et al., 2007). Novamente, eis aí mais um objeto com carcterísticas únicas e interessantes para investigações astrobiológicas.

\subsubsection{Planetas Extrasolares Rochosos}

As técnicas mais utilizadas para a detecção de exoplanetas (trânsito e velocidade radial), por razões já discutidas, favorecem a descoberta de planetas extrasolares mais massivos. Entretanto, com técnicas mais avançadas e os lançamentos da missão CoRoT e da missão Kepler, abriu-se a possibilidade da constatação da existência de planetas e satélites com massas semelhantes a terrestre. Este fato impulsionou estudos teóricos com o objetivo de modelar a estrutura interna de exoplanetas do tipo terrestre. Apesar desse interesse, apenas "Super-Terras" foram detectadas nas Zonas Habitável ou Extremófila dos sistemas planetários conhecidos até o momento. Assim, planetas com valores de massa variando em um intervalo de duas a dez massas terrestres, classificados como Super-Terras, serão os objetos centrais deste estudo. 
Há dois modelos análogos aos modelos terrestres que darão suporte a esta pesquisa (Valencia et al., 2006; Sotin et al., 2007), pois fornecem uma boa estimativa da razão massa-raio para alguns tipos de exoplanetas. Valencia et al. (2006) estimaram a estrutura interna de planetas rochosos com valores de raios tais que a massa deles não ultrapassasse o valor de dez massas terrestres. Nesse modelo, densidade, gravidade, massa e pressão, são representados como funções da distância ao centro do planeta. O manto é constituído pelo mineral olivina e o centro composto principalmente por ferro, com $8 \%$ de silício. Por analogia com a Terra, o modelo contabiliza na simulação os processos de convecção nos mantos superior e inferior, assim como o processo de condução de calor na superfície e nas zonas de contorno. O modelo propõe uma lei de potência que descreve a relação massa-raio para exoplanetas do tipo Super-Terras (Valencia et al., 2006):

$$
\frac{R_{p}}{R_{\oplus}}=\left(\frac{M_{p}}{M_{\oplus}}\right)^{(0,267)}
$$

Um modelo similar também foi desenvolvido pelos autores para caracterizar exoplanetas menos massivos que a Terra, ou seja, com massas em um intervalo de 0,05-0,5 massas terrestres. Seguindo a classificação adotada neste trabalho, esse intervalo de massa corresponde a objetos classificados como Mercurianos ou Sub-Terras, mas que os autores classificaram como Super-Mercúrios. A composição assumida no modelo é similar à terrestre, mas a fração de massa no núcleo é mais alta, por volta de $60 \%$, correspondendo à estrutura interna de Mercúrio. Com tais considerações, a lei de potência torna-se:

$$
\frac{R_{p}}{R_{\oplus}} \propto\left(\frac{M_{p}}{M_{\oplus}}\right)^{0,3}
$$

Paralelamente aos estudos realizados por Valencia et al. (2006), Sotin et al. (2007) desenvolveram um modelo para caracterizar exoplanetas do tipo terrestre baseado em planetas rochosos e objetos (satélite e planetas) localizados além da snow line do Sistema Solar. Eles levaram em consideração na contrução de seu modelo parâmetros como a distância da estrela, o conteúdo de magnésio no manto, a fração de massa de água e a massa total do planeta. Seu modelo é constituído por cinco camadas: no centro, um núcleo rico em ferro fluido, consistindo de uma mistura de Fe e FeS, com $80 \%$ de ferro puro; um manto inferior de silicato constituído por uma mistura de silicatos a altas pressões, rico em ferro e magnésio; um manto superior composto por olivina e enstatita; uma camada 
de gelo a alta pressão; e uma hidrosfera, onde a água é encontrada na forma líquida ou na forma de gelo. A relação massa-raio proviniente deste modelo concorda com os valores encontrados por Valencia et al. (2006):

$$
\frac{R_{p}}{R_{\oplus}}=a\left(\frac{M_{p}}{M_{\oplus}}\right)^{b}
$$

Os valores dos coeficientes $a$ e $b$ são iguais a 1 e 0,274 para planetas do tipo SuperTerras.

\subsubsection{Planetas Extrasolares Oceânicos}

A possível existência de planetas oceânicos foi sugerida por Léger et al. (2004). Esses planetas são caracterizados por serem pouco massivos (consequentemente acretam um menor envoltório gasoso durante seu processo de formação), menos densos que os planetas rochosos de massa equivalente e capazes de abrigar oceanos profundos. Certamente devem ter sido formados em regiões mais externas dos sistemas planetários onde a condensação da água pode ocorrer e, ao passar por um processo migratório, atingido regiões mais internas. A descoberta do exoplaneta OGLE-2005-BLG-390Lb (Beaulieu et al., 2006) provavelmente confirma a hipótese da existência desses planetas.

O modelo desenvolvido por Sotin et al. (2007) permite uma simulação satisfatória da estrutura interna de planetas oceânicos, levando a uma relação massa-raio igual a:

$$
\frac{R_{p}^{o c}}{R_{\oplus}}=a\left(\frac{M_{p}}{M_{\oplus}}\right)^{b}
$$

Os valores dos coeficientes $a$ e $b$ para planetas oceânicos com massas em um intervalo de 0,01 - 1 massas terrestres são de 1,258 e 0,302 respectivamente, entretanto estes mesmos coeficientes possuem valores iguais a 1,262 e 0,275 para planetas oceânicos com intervalos de massa igual de $1-10$ massas terrestres.

Cálculos baseados em simulações mostram que exoplanetas contendo $50 \%$ de massa em água possuem seus raios com valores $25 \%$ maiores do que os raios de planetas com composição semelhante à terrestre (Sotin et al., 2007). 


\subsubsection{Planetas Extrasolares Gigantes}

Os exoplanetas do tipo Jupiterianos apresentam características distintas quando se consideram as suas distâncias orbitais. Os Hot Jupiters são planetas gigantes gasosos localizados bem próximos a estrela central do sistema planetário. Esta característica faz com que as temperaturas no topo de suas nuvens, constituídas por gases leves como hidrogênio e hélio, atinjam valores maiores ou próximos a $2000 K$. Entretanto, o intenso campo gravitacional destes objetos massivos assegura que estes elementos não escapem quando expostos a temperaturas da ordem de milhares de graus. Já os exoplanetas Jupiterianos mais afastados da estrela central do sistema planetário, conhecidos como Cold Jupiters, são relativamente frios, apresentando temperaturas no topo das nuvens que se aproximam das temperaturas encontradas em Júpiter, ou seja, aproximadamente $133 \mathrm{~K}$. Estes planetas podem ser bem semelhantes ao planeta gigante gasoso do Sistema Solar, principalmente se apresentarem rápida rotação.

Os exoplanetas do tipo Netunianos são também classificados de acordo com sua posição orbital em relação à estrela central do sistema planetário. Os Hot Netunos e os Cold Netunos, são exoplanetas com massa inferior aos Hot Jupiters e Cold Jupiters (Stern e Levison, 2002). O fato de possuírem menor massa pode levá-los a uma perda substancial de atmosfera quando estiverem localizados muito próximos à estrela hospedeira.

A descoberta de exoplanetas gigantes orbitando próximos às suas estrelas hospedeiras gerou um desconforto na comunidade científica, pois tal observação não era prevista pela teoria padrão de formação planetária. As pequenas órbitas observadas vão de encontro à teoria que descreve a formação de planetas gigantes em regiões mais distantes do disco protoplanetário, numa escala de tempo de aproximadamente $10^{7}$ anos (Haisch et al., 2001). A única explicação possível para estas observações tem como base teórica os processos migratórios, onde planetas gigantes são formados em regiões externas da nebulosa protoestelar e sofrem um processo de migração na direção interna do sistema planetário. Tal cenário será discutido à frente. 


\subsection{Formação Planetária}

Vários estudos teóricos versando sobre formação planetária foram desenvolvidos ao longo do tempo e tornaram-se ferramentas importantes na projeção e análise dos dados obtidos por meio de missões observacionais. As ideias fundamentais sobre a teoria da formação dos planetas terrestres foram formuladas em 1969 por Safronov, em sua clássica monografia intitulada Evolution of the Protoplanetary Cloud and Formation of the Earth and the Planets. Porém, já em 1796, Laplace havia proposto uma teoria com o objetivo de explicar a formação de planetas gigantes.

Acredita-se que os planetas terrestres tenham sido formados via acresção de corpos sólidos com tamanhos da ordem de quilômetros, originados a partir de um processo de sedimentação e crescimento colisional de grãos de poeira no disco protoplanetário (Lissauer, 1993). O tempo de formação completa dos planetas terrestres, por meio da acresção de planetesimais, é da ordem 10 - 100 milhões de anos (Raymond et al., 2006). Safronov foi o primeiro a apresentar um estudo detalhado sobre os diferentes estágios de formação dos planetas terrestres.

O processo de formação de planetas gigantes tem sido explicado com o auxílio de duas teorias distintas. A primeira teoria, conhecida como Modelo de Formação Planetária por meio de Instabilidades Gravitacionais (top-down model) foi primeiramente proposta por Laplace em 1796. Kuiper, em 1949, e posteriormente A. G. W. Cameron nos anos sessenta e setenta desenvolveram versões modernas do modelo original proposto por Laplace. De acordo com essa teoria, os planetas gigantes são formados por meio de um colapso ocasionado por sua própria gravidade, envolvendo um processo de balanço entre as altas densidade e temperatura locais, seguido de uma fragmentação do disco protoestelar (Papaloizou e Terquem, 1999). A segunda teoria que tenta explicar a formação de planetas gigantes foi proposta em 1973 por Cameron e é conhecida como Core Accretion Model (bottom-up model). Este modelo teórico descreve o processo de formação de planetas gigantes como sendo iniciado por meio da construção de um núcleo sólido, seguindo o mesmo caminho de evolução visto na teoria que descreve a formação dos planetas terrestres. Após este núcleo ter adquirido massa suficiente para ligar-se gravitacionalmente ao gás em que está inserido (aproximadamente dez massas terrestres), um envelope gasoso começa a formar-se em torno do núcleo e em seguida ocorre a constituição do próprio planeta. Os planetas 
gigantes devem ser formados em escalas de tempo próximas à duração do disco gasoso, ou seja, em um intervalo $1-10$ milhões de anos (Briceño et al., 2001).

Espera-se que esta rápida e simples apresentação das principais teorias de formação planetária venha contribuir ao entendimento e análise dos dados observacionais referentes aos sistemas extrasolares, além de apontar para uma explicação coerente para a segregação existente entre planetas terrestres e planetas gigantes, comentada de forma breve no capítulo 1.

\subsection{Processos Migratórios}

A descoberta de planetas gigantes com períodos orbitais da ordem de dias, os chamados Hot Jupiters, apontam para a existência de um mecanismo de redução de órbita muito eficiente, já que a possibilidade de formação destes objetos localizados tão próximos à estrela hospedeira é muito improvável (Bodenheimer et al., 2000). A existência destes exoplanetas não foi uma completa surpresa, pois já eram previstos por modelos computacionais teóricos. Estes modelos apontavam para a significativa mobilidade radial que os planetas poderiam apresentar no disco protoestelar (Lin e Papaloizou, 1986).

Há três mecanismos principais propostos para tentar explicar a localização de planetas tão próximos à estrela central. Um deles está baseado na interação gravitacional entre dois ou mais planetas com massas comparaveis à massa de Júpiter, que podem ter suas órbitas cruzadas e consequentemente serem ejetados ou caírem para órbitas menores (Rasio e Ford, 1996; Weidenschilling e Marzari, 1996). Porém, este mecanismo é inadequado para explicar a grande quantidade de planetas observados, com períodos orbitais curtos. Outro mecanismo, conhecido como Migration Instability (Murray et al., 1998; Malhotra, 1993), considera interações ressonantes entre o planeta e os planetesimais localizados dentro de sua órbita, levando à ejeção destes planetesimais e ao decaimento orbital do planeta. Entretanto, para este processo ser viável o disco protoplanetário deveria ser bem massivo, condição pouco provável. Segundo Papaloizou e Terquem (2005), para mover um planeta com a massa de Júpiter, localizado a $5 U A$ de distância até órbitas menores, seria necessário um disco contendo uma massa de Júpiter em planetesimais e um conteúdo gasoso equivalente a um décimo da massa solar.

O terceiro mecanismo e mais utilizado para descrever o processo de migração de um 
exoplaneta na direção do interior do sistema planetário, propõe a existência de interações envolvendo forças de maré entre os protoplanetas e o disco de gás em torno da nebulosa planetária (Goldreich e Tremaine 1979, 1980; Lin e Papaloizou 1979, 1993; Papaloizou e Lin, 1984; Ward 1986, 1997). Há dois tipos importantes de migração através de interações de maré: a migração de tipo $I$, onde a massa do planeta é desprezível e a migração de tipo II, onde a massa do planeta torna-se importante, quando comparadas à massa do disco.

A migração de tipo $I$ pode ser entendida como uma interação em que há troca de energia e momento angular entre o disco e o planeta (Goldreich et al., 1980). Goldreich e Tremaine (1980) concluíram que partes do disco dentro e fora da órbita do planeta adicionam e removem momento angular e energia na órbita planetária. Há, logicamente, uma efetiva interação entre os planetas e as partes internas e externas do disco, ou seja, a porção interna do disco "empurra" o planeta para posições orbitais externas, enquanto a porção externa do disco "empurra" o planeta para posições orbitais internas. Ward (1997) mostrou que o torque externo em geral predomina, resultando numa diminuição da órbita do planeta.

Goldreich e Tremaine (1980) demonstraram que a taxa de migração continua a aumentar linearmente com o aumento da massa do protoplaneta até que haja uma saturação do torque e o planeta empurre fortemente as partes interna e externa do disco independentemente, abrindo um "gap"próximo a órbita do planeta. O estabelecimento de um "gap" ou barreira contra a passagem do material do disco através de sua órbita caracteriza a migração de tipo II (Lin e Papaloizou, 1986). Assim, o planeta fica ligado à evolução viscosa do próprio disco de gás, sendo deslocado para posições orbitais interiores devido ao contínuo fluxo líquido de materiais que entram através do "gap". Este tipo de migração é que melhor explica a origem dos Hot Jupiters.

Há ainda um outro tipo de migração, denominada migração de tipo III (Masset e Papaloizou, 1986; Artymowics, 2004), que é uma nova forma de explicar o fenômeno migratório em discos massivos e que pode ser impulsionado por torques coorbitais. Porém, os detalhes relativos aos modelos de migração planetária fogem ao escopo deste trabalho.

A escala de tempo para migrações do tipo I é relativamente curta, por volta de $10^{4}$ anos (duas ou três vezes menor que a escala de tempo de existência do disco de gás) para um planeta de massa aproximadamente igual a dez vezes a massa da Terra, localizado em 
um disco suficientemente viscoso (Ward, 1997). Nota-se que os processos de migração $I$, II e III são desencadeados pela mudança de momento angular ocasionada pela interação entre o protoplaneta e o disco gasoso. Este fenômeno é iniciado por ondas de excitação, no caso $I$, pela combinação de ondas de excitação e dissipação de choques, no caso $I I$, e pela troca direta com o material do disco que atravessa a órbita do planeta, no caso III. Desse modo, estes processos devem ocorrer no disco protoplanetário em uma escala de tempo menor do que o tempo necessário para que o conteúdo de gás se disperse.

O tema referente ao processo de migração de exoplanetas é complexo e ainda não totalmente compreendido. Porém, se dispõe de um conjunto de teorias e conceitos importantes para a compreensão das observações desses objetos que apresentam, às vezes, características singulares, quando comparados aos planetas existentes no Sistema Solar. 
Capítulo 3

\section{Extremófilos}

Extremófilos são micro-organismos que, contrariamente à imensa maioria dos organismos terrestres, vivem e até mesmo exigem para sua sobrevivência condições físicas ou geoquímicas extremas, em termos de temperatura, umidade, pressão, salinidade, pH, etc, podendo, inclusive, ser milhares de vezes mais resistentes à radiação que os seres humanos (Cavicchioli, 2002).

Descobertos na Terra há cerca de trinta anos, os extremófilos são candidatos naturais para existirem em meios extraterrestres, onde condições extremas são eventualmente encontradas. No Sistema Solar, exemplos de tais meios são: Marte (baixas pressão, temperatura e umidade), o satélite de Saturno, Titã, (pressão de 1,5 bars, baixíssima temperatura, e composição superficial de amônia, água e hidrocarbonetos) e o satélite de Júpiter, Europa (onde parece existir um vasto oceano com temperatura amena sob a superfície) (Raulin, 2005).

A capacidade de sobrevivência de micro-organismos dentro de pedras e a consequente descoberta de uma biosfera subterrânea na Terra (Pedersen, 2006), mostram que a vida pode existir na ausência de luz e de nutrientes líquidos externos, inclusive no interior de meteoritos. Pode-se igualmente mostrar que organismos são capazes de sobreviver a eventos cataclísmicos, como os que envolvem cataclismas planetários em larga escala, incluindo queda de meteoritos, suficientes para esterilizar a superfície da Terra (Paulino-Lima et al., 2010).

A ideia da panspermia, de que micróbios vindos de fora possam ter inoculado e em seguida colonizado os oceanos terrestres foi desenvolvida na Grécia antiga e repensada cientificamente no início do século $X X$ (Arrhenius e Borns 1908). Em apoio a ela, existem 
evidências da existência de possíveis fósseis e bio-marcadores em meteoritos marcianos, como o ALH84001 (McKay et al., 1996), cuja temperatura interna não deve ter sido superior a $40{ }^{\circ} \mathrm{C}$ (Weiss et al., 2000). Os meteoritos poderiam também proporcionar proteção contra os efeitos bio-degradantes da radiação UV. Além disso, um número significativo deles pode ter viajado entre os planetas do Sistema Solar em trajetórias de menos de 10 anos (Weiss et al., 2000). Mesmo que a duração de uma viagem interplanetária eventual seja muito grande, existem evidências da capacidade de sobrevivência de micro-organismos por milhões de anos em estado latente (Cano e Borucki, 1995). Esses e outros fatos indicam que a hipótese da panspermia envolvendo extremófilos é plausível, inclusive em termos galácticos (Paulino-Lima et al., 2010; 2011).

Este capítulo inicia-se com uma breve taxonomia dos principais organismos extremófilos e sua relação com o ambiente em que vivem, apontando os principais mecanismos de adaptação biológica criados para tolerar as alterações observadas dos limites necessários ao desenvolvimento da vida do ponto de vista antrópico. Na sequência, são apresentados os principais ambientes terrestres onde estes micro-organismos estão presentes e, finalmente, é feita uma observação a respeito das caracterísitcas dos possíveis ambientes extremófilos existentes no Sistema Solar.

\subsection{Categoria de Extremófilos e Definição de Ambiente Extremo}

Os desafios impostos à sobrevivência em ambientes extremos terrestres e provavelmente extraterrestres estão ligados a fatores químicos e físicos, como a temperatura, o nível de salinidade, a exposição à radiação, aos valores extremos de pH, etc. Na tabela 3.1, baseada nos estudos de Rothschild e Mancinelli (2001), são apontadas algumas categorias de extremófilos terrestres e seus habitats extremos.

Ao considerar-se o fato de que organismos extremófilos vivem confortavelmente em ambientes extremos faz surgir a seguinte questão: como definir um ambiente extremo? Será considerado extremo o ambiente hostil à sobrevivência humana, ou seja, aquele que ultrapasse os limites físico-químicos ideais para o desenvolvimento de organismos mesófilos (vide tabela 3.1). Esta visão antropocêntrica, apesar de subjetiva, norteará a definição do significado de "extremo" nesta pesquisa. 
Tabela 3.1 - Extremófilos terrestres e seus habitats extremos.

\begin{tabular}{ccccc}
\hline \hline Parâmetro Ambiental & Tipo & Sobrevivência & Ecossistema & Exemplo \\
\hline \hline Temperatura & Mesófilos & $15-50^{\circ} \mathrm{C}$ & superfície terrestre & Homo sapiens \\
\hline \hline Temperatura & Termófilos & $60-80^{0} \mathrm{C}$ & gêiseres (Yellowstone) & Synechococcus lividus \\
\hline \hline Temperatura & Hipertermófilos & acima de $80^{0} \mathrm{C}$ & ventos hidrotermais & Pyrolobus fumarii \\
\hline \hline Temperatura & Psicófilos & abaixo de $15^{0} \mathrm{C}$ & lagos antárticos (Vostok) & Psychrobacter \\
\hline \hline $\mathrm{pH}$ & Acidófilos & baixo pH & minas ácidas & Cyanidium caldarium \\
\hline \hline pH & Alcalófilos & pH $>9$ & lagos de soda & Natronobacterium \\
\hline \hline Pressão & Halofílicos & $2-5 \mathrm{M}$ NaCl & minas salinas & Dunaliella salina \\
\hline \hline Radiação & Barofílicos & altas pressões & subsuperfície terrestre & Escherichia coli \\
\hline \hline Humidade & Radiófilos & altas doses de radiação & reatores nucleares & Deinococcus radiodurans \\
\hline \hline
\end{tabular}

\subsubsection{Extremófilos e Ambientes de Temperaturas Extremas}

Valores extremos de temperatura podem criar uma série de empecilhos ao desenvolvimento da vida, entretanto, conhecer os limites em que organismos extremófilos se desenvolvem pode fornecer parâmetros importantes na definição de habitabilidade. A maioria dos materiais biológicos quando expostos a temperaturas elevadas sofrem processos físico-químicos que dificultam a manutenção da vida: início da desnaturação de proteínas expostas a temperaturas da ordem de $100{ }^{\circ} \mathrm{C}$, ocasionando a perda de suas estruturas quartenária, terciária e até mesmo secundária, a degradação dos ácidos nucleicos - que é influenciada também pela composição das bases (ligações do tipo A-T são menos termoestáveis que ligações do tipo G-C), pelo comprimento dos polímeros, pelo solvente utilizado e pela concentração de íons na solução - e o processo de desnaturação enzimática que ocasiona a inativação de sua atividade catalítica; observa-se também o aumento considerável da fluidez das membranas, permitindo a passagem livre de íons até atingir níveis letais (Driessen et al., 1996). Outros problemas, como por exemplo, a alteração da solubilidade de gases na água, prejudicando organismos aquáticos que se utilizam de gases como $\mathrm{CO}_{2}$ e $\mathrm{O}_{2}$ e a degradação da clorofila quando exposta a temperaturas de aproximadamente $75{ }^{0} \mathrm{C}$, levando ao término imediato do processo fotossintético, são relatados (Rotschild e Mancinelli, 2001).

Por outro lado, quado se considera baixas temperaturas, outros processos físico-químicos limitadores ao desenvolvimento da vida ficam evidenciados e o papel desempenhado pela água como solvente, reagente ou produto de processos metabólicos fica comprometido 
(Franks, 1986). Isto ocorre porque devido ao congelamento da água e a consequente formação de cristais de gelo, ocorre o rompimento de membranas celulares; o congelamento da água intracelular é quase sempre letal. Porém, há uma exceção relatada cientificamente: o organismo nematóide Panagrolaimus davidi resiste ao congelamento de toda a água de seu corpo (Wharton e Ferns, 1995). Sabe-se que algumas espécies de rãs, tartarugas e cobras podem tolerar o congelamento da água no meio extracelular, porém somente após terem produzido moléculas anti-congelantes (Storey e Storey, 1996).

Na figura 3.1 é mostrada a taxa de crescimento em função da temperatura para algumas categorias de extremófilos.

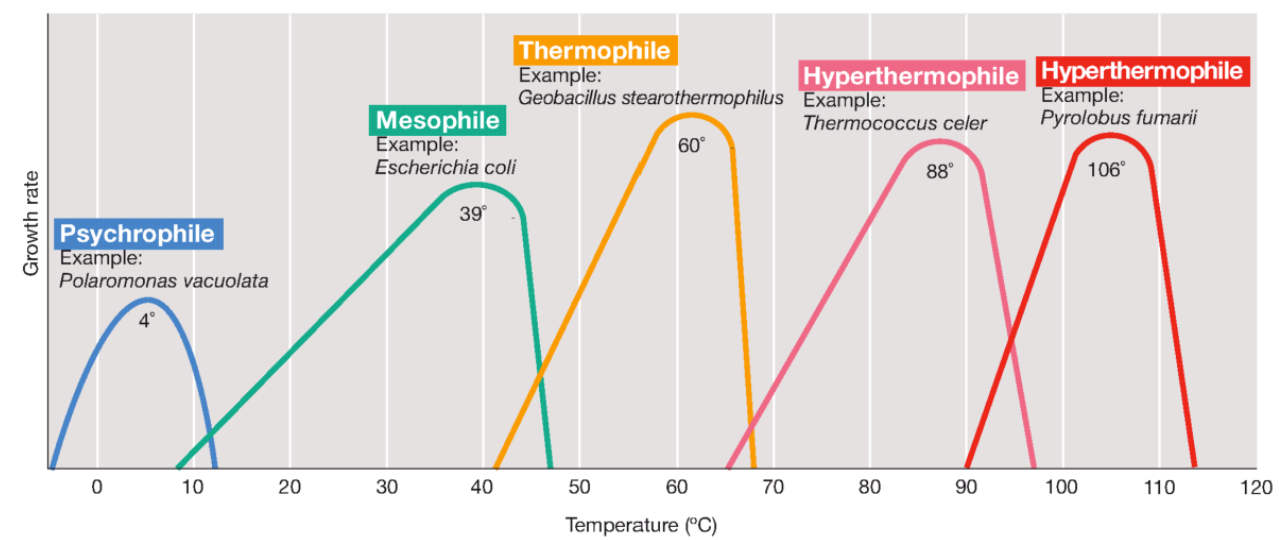

Figura 3.1: Taxa de crescimento em função da temperatura para algumas categorias de extremófilos. Fonte: Madigan et al. (2012), p. 135.

Observa-se portanto, que na natureza há dois grupos de micro-organismos que delimitam os extremos relacionados à temperatura e são de extrema importância para a busca de vida em ambientes extraterrestres: de um lado, os hipertermófilos, apresentando um crescimento ótimo em temperaturas acima de $80{ }^{\circ} \mathrm{C}$, e do outro, os psicrofílicos, com crescimento ótimo em temperaturas menores que $15{ }^{\circ} \mathrm{C}$. Entre estes dois extremos há um grupo de organismos que possui crescimento ótimo em temperaturas mais amenas, ou seja, abaixo de $80{ }^{\circ} C$, ao qual possui também importância notável nessa busca; estes organismos são chamados de termófilos, dentre os quais destacam-se bactérias fototróficas, as eubactérias e as arqueas. Vale lembrar que o limite máximo de temperatura suportado por organismos eucariontes (protozoários, algas, plantas, animais e fungos) é de aproximadamente $60{ }^{0} \mathrm{C}$.

Por um longo período, o limite máximo de temperatura observado para organismos 
terrestres era de $110{ }^{\circ} \mathrm{C}$, referente ao micróbio Pyrodictium occultum, encontrado nas águas rasas da praia da Ilha do Vulcão na Itália (Stetter, 1982). Este limite superior passou a ser estimado em aproximadamente $115{ }^{0} \mathrm{C}$ com a descoberta do micróbio Pyrolobus fumarii, que habita mares profundos (Blochl et al., 1997). Porém, há relatos da sobrevivência de estirpes do micro-organismo Pyrolobus fumarii em temperaturas superiores a $121{ }^{0} \mathrm{C}$ (Rothschild e Mancinelli, 2001; Kashefi e Lovley, 2003; Southam et al., 2007). Vários organismos vivem em temperaturas próximas ou acima do ponto de ebulição da água. Estes organismos, conhecidos como hipertermófilos (crescimento ótimo acima de $80{ }^{\circ} \mathrm{C}$ ), são encontrados em todos os lugares onde existe atividade vulcânica, seja na superfície terrestre ou no mar (Stetter, 1996). Há também, uma grande população destes micróbios vivendo em grandes profundidades, dentro de fontes hidrotermais localizadas no fundo do oceano, onde obtêm energia por meio da exploração de produtos químicos oriundos do fluido quente que é expelido através de certas aberturas. A maioria dos hipertermófilos são procariontes, ou seja, micro-organismos unicelulares desprovidos de uma membrana celular, cujo DNA cromossômico está diretamente em contato com o citoplasma da célula. Os procariontes são divididos em dois grupos filogenéticos distintos: as bactérias e as arqueas. Os micro-organismos mais adaptados ao limite superior de temperatura pertecem ao grupo das arqueas. O limite máximo de temperatura tolerada pelas bactérias é de apenas $95{ }^{\circ} \mathrm{C}$ (Stetter, 1996). As arqueas, mesmo suportando temperaturas da ordem de $115{ }^{0} \mathrm{C}$, apresentam um crescimento ótimo em faixas de temperaturas um pouco menores, no intervalo de aproximadamente $95-106{ }^{\circ} \mathrm{C}$. Este fato sugere que há um ou mais fatores críticos que limitam a proliferação da vida terrestre de forma eficiente, mesmo em ambientes cuja temperatura já tenha atingido o limite superior. A água não deve ser o fator limitante, pois há ambientes pressurizados estéreis onde existe água a altas temperaturas (Trent, 1984). A figura $3.2^{8}$ ilustra alguns ambientes terrestres onde observam-se temperaturas extremas.

Um fator importante a ser analisado quando se considera a proliferação da vida em ambientes com temperatura da ordem do limite superior é a instabilidade térmica de ligações covalentes envolvidas na constituição das estruturas de moléculas biológicas. Proteínas e

\footnotetext{
${ }^{8}$ A figura pode ser acessada em: http://earthdata.nasa.gov/featured-stories/featuredresearch/fathoming-antarctica. Acesso: 22/08/2012.
} 
(a)
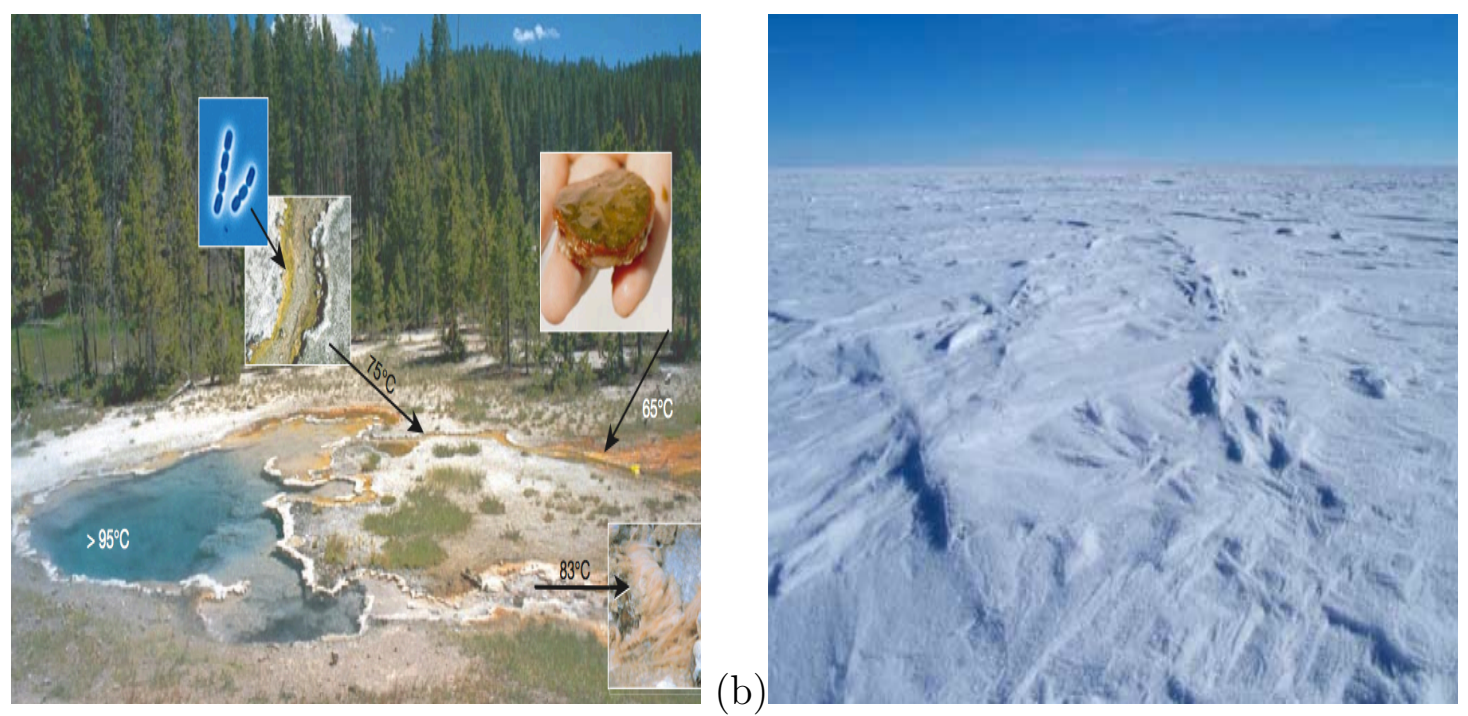

Figura 3.2: Exemplos de ambientes extremos terrestres. (a): Yellowstone National Park, onde há microorganismos adaptados a sobreviver em altos valores de temperatura. Fonte: Rothschild e Mancinelli (2001). (b): superfície acima do Lago Vostok, local onde acredita-se que extremófilos podem sobreviver. Fonte: M. Studinger, LDEO.

enzimas provenientes de hipertermófilos podem ser estáveis a temperaturas da ordem de aproximadamente $142{ }^{\circ} \mathrm{C}$ (Rotschild e Mancinelli, 2001). Essa termo-estabilidade ocorre devido a maior presença de interações não covalentes entre os aminoácidos que mantêm a estrutura da cadeia polipeptídica. A dupla hélice do DNA é muito estável quando se considera temperaturas próximas de $107{ }^{\circ} \mathrm{C}$ (Marguet e Forterre, 1994). Entretanto, o DNA é quimicamente degradado por diversos mecanismos quando exposto a temperaturas acima desse valor; o mecanismo mais importante é a remoção das bases de purina (depurinização) e o consequente processo de clivagem (Lindahl, 1993). Nota-se, que os hipertermófilos possuem mecanismos de reparo ao DNA muito otimizados. Sabe-se que as moléculas de RNA são instáveis a altas temperaturas, porém os micro-organismos hipertermófilos possuem mecanismos que protegem os RNAs mensageiro e ribossômico, expostos a temperaturas elevadas.

Há uma grande quantidade de organismos, especialmente micro-organismos, habitando solos congelados de ambientes árticos e alpinos (Russel, 1992). Bactérias podem sobreviver dentro de rochas nos vales áridos da Antártica, crescendo em faixas de temperatura que vão de aproximadamente $-10 \mathrm{a}-20{ }^{0} \mathrm{C}$ nas faces rochosas expostas ao Sol durante o verão (Friedman, 1993). A maioria dos organismos adaptados a sobreviver em ambientes gelados são bactérias (todos os tipos) ou micro-organismos eucarióticos. Apesar disso, uma 
arquea foi identificada nas águas glaciais da Antártica através da amplificação direta de seu material genético (DeLong et al., 1994).

Muitos micróbios e linhagem de células podem ser preservadas de forma satisfatória em nitrogênio líquido a temperaturas em torno de $-196{ }^{\circ} C$, sendo que a menor temperatura associada a uma comunidade de micro-organismos ativa era de $-18{ }^{0} \mathrm{C}$ (Rotschild e Mancinelli, 2001). Porém, segundo Price e Sowers (2004), há evidências do metabolismo microbiano no gelo glacial antártico, onde as temperaturas atingem valores próximos a $-40{ }^{0} C$. O limite inferior para se encontrar vida em ambientes terrestres não é claro devido à dificuldade em se monitorar o crescimento e a atividade metabólica em temperaturas abaixo de zero. Muitos estudos ainda precisam ser realizados para se impor um limite exato.

\subsubsection{Extremófilos e Ambientes Salinos}

Organismos que sobrevivem em ambientes contendo altas concentrações de sal são conhecidos como halofílicos extremos. Sais monovalentes e divalentes, como $\mathrm{K}^{+}, \mathrm{Na}^{+}, \mathrm{Zn}^{++}$, $\mathrm{Mn}^{++}, \mathrm{Fe}^{++}, \mathrm{Cl}^{-}$, etc, são essenciais para o desenvolvimento da vida na Terra, já que participam como co-catalizadores de muitas atividades enzimáticas. No entanto, deve-se observar que apesar dos organismos serem dependentes de determinadas concentrações de sal, a concentração máxima tolerada pela maioria está abaixo de 0,5\%. Este fato ocorre porque altas concentrações salinas perturbam a rede de interações iônicas que dão forma às macromoléculas e mantêm agrupados os compostos macromoleculares. Micro-organismos extremófilos halofílicos, dentre eles, os procariontes e eucariontes, toleram concentrações salinas em uma faixa que varia de $1-20 \%$ de $\mathrm{NaCl}$ e, alguns procariontes, os halofílicos extremos, podem sobreviver em ambientes hipersalinos (salinas e lagos salgados) que apresentam concetrações de $\mathrm{NaCl}$ da ordem de 250-300 g.l $\mathrm{l}^{-1}$; os halofílicos extremos, quando expostos a concentrações de $\mathrm{NaCl}$ menores que 10 \% não sobrevivem (Herbert and Sharp, 1992).

Há duas estratégias usadas pelos halofílicos para lidar com ambientes salinos, ou seja, evitar a perda da água do meio celular. A primeira estratégia, usada pelas algas eucarióticas e pela maioria das bactérias, é a acumulação em seu citoplasma de pequenos compostos orgânicos, conhecidos como solutos compatíveis; neste caso, o mecanismo intracelular do 
organismo é protegido do ambiente extremo. A segunda estratégia, principalmente utilizada pelas arqueas, é a acumulação de altas concentrações de $\mathrm{KCl}$ e $\mathrm{MgCl}_{2}$ em seu citoplasma (próximo da saturação); aqui, o meio intracelular está em contato direto com o alto conteúdo salino. Nas arqueas halofílicas, o meio intracelular é adaptado às altas concentrações salinas do citoplasma, o que significa baixa atividade dependente do solvente água. As proteínas existentes em organismos halofílicos extremos são ativadas a altas concentrações salinas e desnaturam-se com a remoção delas.

As recentes descobertas de evaporitos (rochas sedimentares que apresentam minerais salinos) em Marte e de vida em evaporitos terrestres, associadas à resistência de organismos halofílicos expostos a intensa radiação, ratificam a importância destes organismos no estudo astrobiológico de objetos existentes no sistema solar e além (Rothschild, 1990).

\subsubsection{Extremófilos e Ambientes Ácido e Alcalino}

O ambiente químico mais favorável à vida ocorre em $\mathrm{pH}$ neutro. Entretanto, alguns micro-organismos se adaptaram a condições extremas de $\mathrm{pH}$, sobrevivendo em ambientes onde esse parâmetro é muito ácido (próximo de zero) ou básico (próximo de 13), já que conseguem manter seu meio intracelular em uma faixa de $\mathrm{pH}$ entre $4-9$.

Muitas bactérias e arqueas são acidófilas. As arqueas Picrophilus oshimae e Picrophilus torridus vivem em solos secos com valores de $\mathrm{pH}$ abaixo de 0,5 e mantêm certo crescimento quando expostos a valores de pH próximo de zero (Rotschild e Mancinelli, 2001; Schleper et al., 1995); o organismo Ferroplasma acidarmanus, isolado em minas ácidas, pode crescer em ambientes com valores de pH próximos de zero (Edwards et al., 2000). É interessante notar que, muitos micro-organismos além de serem acidofílicos são também termofílicos; a arquea Sulfolobales (organismo que respira enxofre e produz ácido sulfúrico como produto de seu metabolismo) se desenvolve em pH próximo de 2 e acima de $90{ }^{0} \mathrm{C}$.

O conjunto de organismos formado por algumas arqueas e muitas bactérias, conhecido como alcalófilos, vive no outro extremo da faixa de $\mathrm{pH}$, ou seja, em valores de $\mathrm{pH}$ que vão aproximadamente de 9 - 12,9 (Rotschild e Mancinelli, 2001). Estes organismos estão presentes em várias regiões da Terra e, alguns descobertos em lagos de soda ricos em carbonatos, são também halófilos (haloalcalinos). Muitos dos alcalófilos são mesófilos ou termófilos moderados, porém o organismo Thermococus alkaliphilus é um hipertermófilo 
alcalino (Keller et al., 1995).

Organismos acidófilos e alcalófilos contam com sofisticados mecanismos de transporte que mantêm o pH do meio intracelular próximo da neutralidade, bombeando ou excretando prótons. Estes mecanismos protegem o meio intracelular contra valores externos de pH. Eles são hábeis na manutenção de gradientes adequados de prótons ou $\mathrm{Na}^{+}$, a fim de sustentar o mecanismo de produção de energia. Estes organismos, quando ainda termófilos, lidam com problemas específicos de manutenção da permeabilidade ideal de suas membranas em ambientes desbalanceados ionicamente; essa particularidade pode explicar o porque do limite superior de temperatura, para alcalófilos e acidófilos, ser próximo de $90{ }^{0} C$ e não $115{ }^{0} \mathrm{C}$.

\subsubsection{Extremófilos e Ambientes a Altas Pressões}

Organismos podem sobreviver em ambientes expostos a altas pressões, como é observado em comunidades microbianas localizadas nas profundezas do mar (submetidos a pressões de 1100 bars). Porém, alguns destes micro-organismos sobrevivem a valores de pressões atmosféricas normais, enquanto outros não. Os limites extremos de pressão para a manutenção da vida em ambientes terrestres não é conhecido, já que habitats submetidos a pressões superiores a 1100 bars ainda não foram explorados. Entretanto, esse limite pode ser muito superior, considerando o fato de que as macromoléculas e os constituintes celulares somente se desnaturam quando expostos a valores de pressão em uma faixa de 4000 - 5000 bars. Ainda não está claro se os organismos que habitam os ambientes profundos desenvolveram mecanismos específicos para adaptarem-se a altas pressões. Sabe-se que alguns hipertermófilos apresentam a taxa de crescimento elevada quando submetidos a altas pressões, mas este fenômeno não é geral e muito menos espetacular; apesar de algumas proteínas de hipertermófilos serem mais ativas a altas pressões, estes valores elevados não alteram a termoestabilidade das macromoléculas (Bernhardt et al., 1984).

É interessante observar que algumas bactérias de superfície, como por exemplo a Escherichia coli e a Shewanella oneidensis, tem demostrado ser metabolicamente ativa a pressões próximas de 16000 bars, pressão esta, muito superior ao limite de pressão conhecido e onde há existência comprovada de organismos (Sharma et al., 2002). 


\subsubsection{Extremófilos e Dessecação}

A dessecação é um método antigo utilizado para preservação de alimentos. Sabe-se que a grande maioria dos organismos terrestres vive na presença de água líquida, entretanto, muitos organismos são adaptados a tolerar a ausência deste solvente. Micróbios e plantas usam a resistência de seus esporos frente à dessecação e suportam longos períodos de seca, além de utlizarem tais esporos como mecanismo eficiente de proteção e dispersão da espécie.

Uma grande variedade de invertebrados, dentre eles, os nematóides e os rotíferos, são organismos anidrobióticos e alguns, como os tardígrados, podem resistir muito bem à dessecação por períodos acima de 100 anos, como por exemplo os encontrados sob amostras de herbários (Horikawa et al., 2006). Organismos que podem sobreviver a condições extremas de desidratação, também são resistentes a ambientes onde a temperatura é muito baixa ou muito elevada (curto período de tempo), assim como em ambientes desprotegidos da radiação ionizante (Rotschild e Mancinelli, 2001). As habilidades adaptativas deste grupo de organismos os colocam como habitantes potenciais de planetas (por exemplo Marte) e luas do Sistema Solar.

\subsubsection{Extremófilos e Radiação}

Durante a evolução do planeta, os organismos foram expostos a diversas fontes de radiação, como por exemplo, as fontes naturais oriundas das substâncias radioativas e a radiação ultravioleta de origem solar. A radiação solar sofreu variações em sua interação com esses organismos devido principalmente à variação dos compostos existentes na atmosfera; a radiação ultravioleta abaixo dos $200 \mathrm{~nm}$ foi bloqueada pela atmosfera de $\mathrm{CO}_{2}$, enquanto a radiação de comprimentos de onda abaixo de $300 \mathrm{~nm}$ foi atenuada pelo surgimento do oxigênio e do ozônio há aproximadamente dois bilhões de anos. A proteção da atmosfera contra o efeito da radiação ultavioleta é importante, pois os picos de absorção para os ácidos nucleicos e para as proteínas estão por volta de aproximadamente $260 \mathrm{~nm}$ e $280 \mathrm{~nm}$ respectivamente. Recentemente, os organismos terrestres foram expostos à radiação através de fontes produzidas pelo próprio homem, como por exemplo os reatores nucleares; a radiação danifica os ácidos nucleicos, as proteínas e os lipídios. A molécula de DNA é direta ou indiretamente danificada pela produção de radicais de oxigênio reativos, criando bases modificadas e quebras em fitas simples e duplas. 
O organismo mais interessante para os estudos astrobiológicos, principalmente relacionados à exploração de Marte, é a bactéria Deinococcus radiodurans (figura $3.3^{9}$ ), descoberta por Arthur W. Anderson em 1956, cuja capacidade de sobrevivência à exposição frente a radiações ionizante (acima de $20 k G y$ de radiação gama) e UV (doses acima de $1000 J . m^{-2}$ ) é extraordinária (Battista, 1997). Este organismo é resistente à radiação e também à dessecação. A resistência à radiação não é condição sine qua non para a resistência à dessecação.

(a)
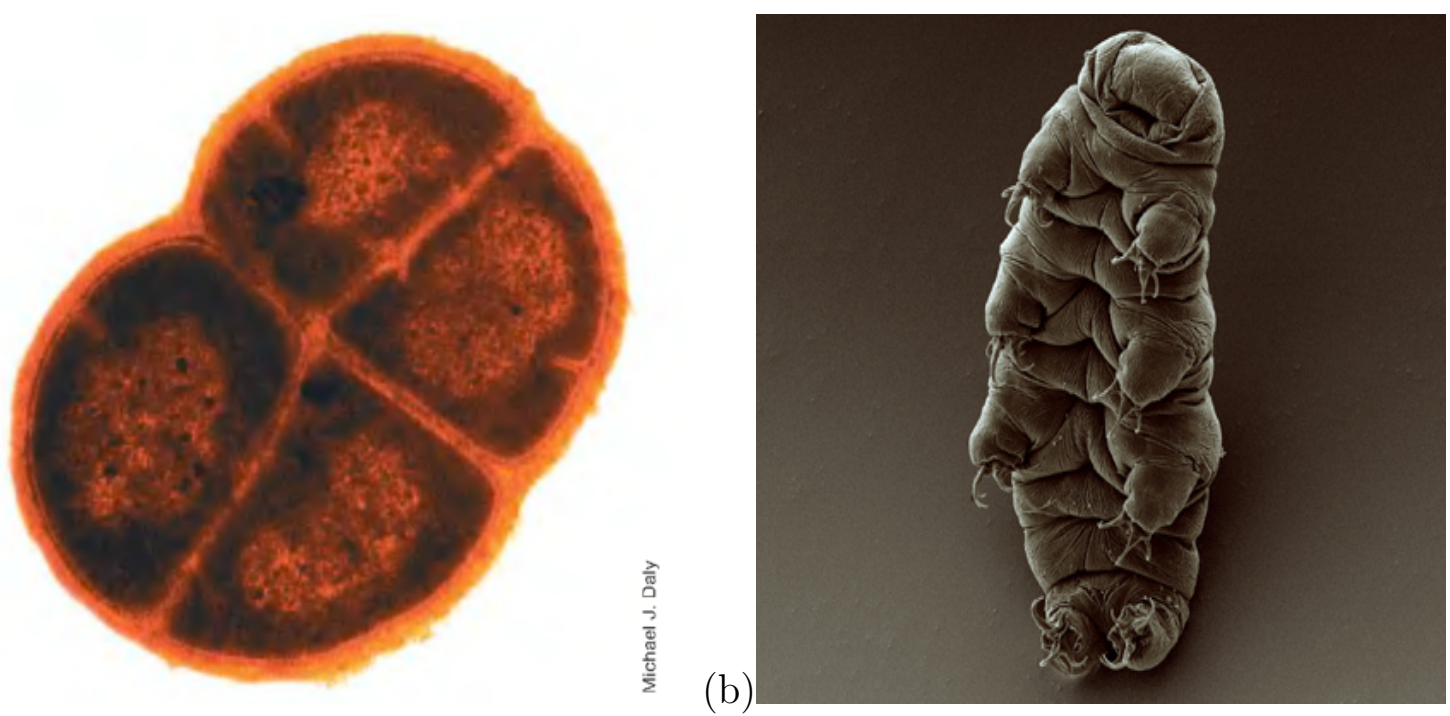

Figura 3.3: Organismos extremófilos aptos a suportarem viagens interplanetárias e sobreviverem em condições superficiais hostis. (a): bactéria Deinococcus radiodurans. Fonte: Madigan et al. (2012), p. 41. (b): tardígrado Hypsibius dujardini. Fonte: Bob Goldstein e Vicky Madden, UNC Chapel Hill.

\subsubsection{Extremófilos e Altas Concentrações de Oxigênio}

Os seres humanos estão adaptados a sobreviverem em concentrações de aproximadamente $21 \%$ de oxigênio, sendo que durante o período Permocarbonífero (248 - 354 milhões de anos) os níveis de oxigênio na Terra podem ter atingido níveis de $35 \%$ (Berner et al., 2003). O metabolismo aeróbico surgiu e tornou-se dominante porque era mais eficiente que o metabolismo anaeróbico quanto à produção de ATP por molécula de glicose.

Durante os processos de redução do oxigênio para água ou da oxidação da água, uma série de espécies reativas de oxigênio são produzidas, das quais a pior para um sistema biológico é o radical hidroxila. O dano oxidativo à molécula de DNA vai desde modificações

\footnotetext{
${ }^{9}$ A figura 3.3 (b) pode ser acessada em: http://tardigrades.bio.unc.edu. Acesso: 22/08/2012.
} 
das bases até a quebra de fitas simples e duplas; há também danos em lipídios e proteínas. Segundo estudos de Jacob e Burri (1996), o aumento da produção de espécies reativas de oxigênio é uma caracterísitica da maioria, senão de todas as doenças humanas, incluindo doenças cardiovasculares e o câncer.

\subsubsection{Extremófilos e Ambientes Subterrâneos}

A vida poderia desenvolver-se em ambientes subterrâneos? Até pouco tempo esta hipótese seria encarada como pouco provável. Entretanto, experimentos conduzidos por alguns cientistas (Parkes et al., 1994) em campos petrolíferos e no curso das perfurações, mostraram a existência de micro-organismos adaptados a estes ambientes.

Recentemente, foi registrada a presença de organismos procariontes em sedimentos marinhos em profundidades superiores a 750 metros abaixo do fundo do mar - $10^{7}$ células $\mathrm{cm}^{-3}$ em 500 metros abaixo do fundo do mar - (Parkes et al., 1994). Em profundidades de no mínimo 432 metros, organismos também tem sido observados em vulcões localizados na crosta oceânica (Torsvik et al., 1996). Estas descobertas apontam para a riqueza de uma biosfera microbiana ainda não explorada e que pode ser tão extraordinária quanto a biosfera da superfície terrestre. A elevada população de organismos procarióticos e suas atividades, estão associadas com os hidratos gasosos. Esta constatação aliada à existência de uma grande população de micro-organismos em reservatórios de óleos fluidos (Haridon et al., 1995), sugerem que os processos envolvidos na formação de gases e óleos podem estar relacionados com esta população de organismos. Organismos procarióticos podem ser responsáveis por reações de formação e dissolução de minerais, assim como pelo registro magnético por meio da produção de minerais magnéticos, como também responsáveis pela produção de gás metano (essencial para a formação de hidratos) em grandes profundidades.

Organismos heterotróficos subterrâneos utilizam-se das sobras de carbono orgânico depositadas em sedimentos e do oxigênio dissolvido na água como fonte de energia. Estes organismos são indiretamente dependentes da atividade fotossintética, ou seja, não sobreviveriam caso suas fontes de nutrientes fossem exauridas. Entretanto, estudos conduzidos por Stevens e McKinley (1995), identificaram a existência de um sistema de micróbios litoautotróficos anaeróbicos, localizado na subsuperfície de aquíferos basálticos. Aparentemente, estas comunidades microbianas adquirem sua energia por meio de processos geoquímicos 
e este fato pode levar à persistência destas comunidades caso as condições na superfície terrestre sejam desfavoráveis à manutenção da vida.

Sendo que o aumento da temperatura é diretamente proporcional à profundidade, devese considerar que hipertermófilos, principalmente os quimiolitoautótrofos são abundantes em ambientes subterrâneos, formando uma biosfera quente e profunda (Gold, 1992). De fato, tem-se relatos de atividade de organismos procariontes em temperaturas próximas de $120{ }^{\circ} \mathrm{C}$ e provavelmente em valores superiores (Parkes e Cragg, 1994). Essas comunidades de micro-organismos sugerem que a vida pode existir abaixo da superfície de satélites e outros planetas (como por exemplo Marte); a não existência de vida na superfície de qualquer corpo celeste não indica necessariamente a ausência de toda a vida.

Há relatos, mesmo que contestados cientificamente, versando a respeito do renascimento de micro-organismos encontrados em rochas antigas, ambientes salinos e até mesmo em regiões com predominância de altas concentrações de carvão. Alguns destes, são microorganismos ressuscitados de rochas de mais de 100 milhões de anos, e outros, datam da era Precambriana, ou seja, de 650 milhões de anos (Kennedy et al., 1994). Muitos destes micro-organismos ressuscitados, mas não todos, são formadores de esporos; alguns organismos como bactérias, fungos e cistos de protozoários desenvolveram a habilidade de produzir esporos extraordinariamente resistentes, que podem sobreviver em ambientes submetidos a condições severas (temperaturas altas, ausência de nutrientes, altas doses de radiação). Lindahl (1993) observou que mesmo protegido contra os efeitos danosos dos raios UV e da radiação ionizante, o DNA sofre modificações químicas espontâneas (depurinização, desamidação da citosina e hidrólise dos fosfodiésteres) durante o período de dormência. Os esporos são protegidos por uma proteína de ligação específica do DNA, que previne a depurinização e provavelmente outros danos, entretanto, não se conhece ao certo a eficácia deste efeito a longos períodos. Estudos dirigidos por Marguet e Forterre (1994) mostram que altas concentrações salinas protegem o DNA das modificações químicas, sugerindo que organismos halofílicos podem ter mais chances de manter seu DNA intacto; o melhor cenário para a conservação do DNA seria, então, ambientes a baixas temperaturas e povoados por organismos halofílicos extremos.

Outro problema que a longo prazo pode desestabilizar a estrutura do DNA é a exposição à radioatividade natural das rochas. Entretanto, alguns organismos como a bactéria Dei- 
nococcus radiodurans são extremamente radio-resistentes e ainda adaptadas a sobreviverem em ambientes secos. Esta bactéria exibe mecanismos eficientes de reparo e recombinação, que permitem à célula reconstruir, a partir de cromossomos danificados, cromossomos intactos (Smith et al., 1992).

Estudos demonstram que mais de $95 \%$ da população encontrada em aquíferos quentes e profundos é composta por arqueas metanogênicas que utilizam $\mathrm{H}_{2}$ e $\mathrm{CO}_{2}$ para produzirem $\mathrm{CH}_{4}$ (Chapelle et al., 2002). Planetas ou satélites que ainda mantêm algum tipo de atividade geotérmica são candidatos a abrigarem vida subterrânea (Weiss et al., 2000). A extraordinária diversidade da biosfera subterrânea terrestre aponta para a grande possibilidade de existirem ambientes extraterrestres (planetas e satélites) similares e propícios a abrigarem alguma forma de vida.

\subsection{Micro-organismos Extremófilos Candidatos a Habitarem Ambientes Extraterrestres}

Como visto acima, micro-organismos extremófilos são encontrados em uma grande variedade de nichos terrestres e por esta razão são candidatos naturais a habitarem ambientes extraterrestres, como planetas e luas. Logo, torna-se necessário a apresentação de alguns dos principais organismos capazes de constituírem comunidades em objetos além da Terra, onde condições físico-químicas adversas podem ser comuns.

\subsubsection{Ferroplasma acidarmanus}

A arquea acidófila Ferroplasma acidarmanus cresce em pH zero. Ela foi encontrada em drenagens de minas ácidas e é capaz de sobreviver em ambientes cuja constituição apresente altas concentrações de ácido sulfúrico, cobre, arsênico, cádmio e zinco, mesmo sendo um microorganismo desprovido de parede celular para protege-lo desse habitat hostil.

\subsubsection{Deinococcus radiodurans}

A bactéria Deinococcus radiodurans pode sobreviver à exposição de 20000 Gy de radiação gama ou a doses acima de $1000 \mathrm{~J} / \mathrm{m}^{2}$ de radiação UV (uma dose de 4-10 Gy pode ser letal aos seres humanos; $1 \mathrm{~Gy}=1 \mathrm{~J} / \mathrm{kg}=100 \mathrm{rad}$ ) (Rothschild e Mancinelli, 2001). 
Essa bactéria cresce em ambientes onde a intensidade de radiação chega a $60 \mathrm{~Gy} / \mathrm{h}$, ou seja, $6000 \mathrm{rad} / \mathrm{h}$, lembrando que a radiação de fundo terrestre varia na faixa de $0,05-20$ rad/ano (Pavlov et al., 2006). Cox e Battista (2005) discutem os mecanismos adaptativos capazes de fornecer a esses micro-organismos condições especiais de reparo ao DNA e de sobrevivência a ambientes áridos; alguns relatos ainda apontam para a possível sobrevivência estendida da Deinococcus radiodurans à exposição ao vácuo espacial, características tais que fazem dela uma provável candidata a habitar ambientes semelhantes aos encontrados em Marte e também a se comportar como um vetor em viagens interplanetárias (PaulinoLima et al., 2011).

\subsubsection{Pyrolobus fumarii}

O hipertermófilo Pyrolobus fumarii, encontrado em ambientes onde há ventos hidrotermais, é um micro-organismo capaz de respirar ferro e crescer em temperaturas acima de $113{ }^{0} \mathrm{C}$ (Rothschild e Mancinelli, 2001). Apenas $1 \%$ desses organismos podem sobreviver a uma hora de exposição em autoclaves, cujas temperaturas alcançam $121{ }^{\circ} \mathrm{C}$. Entretanto, algumas estirpes (Strain 121) sobreviveram a essa faixa de temperatura e ainda dobraram sua população. Estudos mostram que essas estirpes podem sobreviver em temperaturas de $130{ }^{\circ} \mathrm{C}$ por duas horas e que quando são transferidas para ambientes mais amenos ainda se reproduzem (Southam et al., 2007; Kashefi e Lovley, 2003); a baixas temperaturas (abaixo de $85{ }^{\circ} C$ ) as estirpes Strain 121 permanecem viáveis, porém não se observa reprodução.

\subsubsection{Hesiocaeca methanicola}

O verme Hesiocaeca methanicola foi encontrado a 540 metros abaixo da superfície oceânica no Golfo do México, habitando clatratos de metano (Fisher et al., 2000). Esse microorganismo é capaz de sobreviver a ambientes apresentando altas pressões e temperaturas na faixa de $0-5{ }^{0} C$.

\subsubsection{SLIME}

Os estudos de poços naturais, localizados a profundidade de $1,5 \mathrm{~km}$ no rio basáltico $C_{0}$ lumbia, mostraram que a água contida em rochas de mais 35000 anos quase não continham oxigênio dissolvido, e sim, hidrogênio molecular e metano, onde o último, provavelmente 
foi produzido por bactérias que habitam esse nicho (Stevens e McKinley, 1995). Essas bactérias sobrevivem através da produção de energia por meio da interação entre rochas e água. Logo, percebe-se que micro-organismos podem sobreviver em ambientes com escassez de nutrientes, porém contento ao menos água anóxida e algum mineral ferroso. Nesse ambiente, a água pobre em oxigênio reage com minerais e produz hidrogênio molecular, enquanto as bactérias autotróficas transformam compostos inorgânicos em compostos orgânicos, que nesse caso específico é a combinação do hidrogênio molecular com o dióxido de carbono, produzindo metano ou outros compostos orgânicos mais complexos. Assim, identifica-se um ciclo onde organismos autotróficos, por meio de suas excreções orgânicas, distribuem energia para a manutenção de diversas comunidades de micro-organismos. Stevens e McKinley denominaram esses nichos biológicos de SLiME (subsurface lithoautotrophic microbial ecosystem). A compreensão do SLiME é de extrema importância ao estudo de ambientes extraterrestres, já que esse é uma fonte de energia alternativa, ou seja, não depende de oxigênio ou fotossíntese.

\subsubsection{Tardígrados}

Tardígrados são micro-organismos invertebrados que constituem mais de 400 espécies identificadas até o momento. Eles habitam ambientes com altitudes maiores que 6000 metros (Cordilheira do Himalaia) e menores que 4000 metros abaixo do mar; podem sobreviver em temperaturas próximas do zero absoluto e acima dos $151{ }^{0} \mathrm{C}$ (Rothschild e Mancinelli, 2001). Alguns dos tardígrados utilizam compostos anti-congelantes tais como concentrações elevadas de açúcares, sais e aminoácidos para combater o congelamento. Também podem suportar mil vezes mais radiação que a maioria dos organismos vivos $(570000 \mathrm{rad}=5700 \mathrm{~Gy})$ e pressões na faixa dos 6000 atm (Seki et al., 1998). Esses organismos são chamados de survivophiles, pois são capazes de entrar em estado reversível de inatividade, podendo sobreviver aproximadamente a uma década na ausência de água. Em setembro de 2007, a Agência Espacial Européia (ESA) fez experimentos com tardígrados e seus ovos no espaço. Após mais de dez dias de exposição ao vácuo e a intensa radiação UV, as amostras sofreram rehidratação. Todos os tardígrados e seus ovos não sofreram danos relativos à exposição ao vácuo, porém várias espécies sofreram danos advindos da radiação solar não filtrada. Jonsson et al. (2008) evidenciaram que certas espécies de 
tardígrados foram reanimadas sem danos após serem submetidas a doses maiores que 7000 $k J / m^{2}$. Fica claro que o estudo desses organismos é vital para a compreensão da vida em ambientes espaciais e em habitats onde condições adversas são encontradas.

\subsection{Ambientes Extremos no Sistema Solar}

Como serão as condições físico-químicas nos exoplanetas conhecidos e naqueles que eventualmente ainda serão descobertos? Eles teriam ambientes propícios ao desenvolvimento da vida em seu aspecto mais complexo? Caso planetas semelhantes à Terra sejam raros, espera-se ao menos que a maioria dos planetas extrasolares possuam ambientes capazes de oferecer condições ideais ao desenvolvimento de organismos extremófilos. Assim, uma análise dos ambientes extremos presentes no Sistema Solar torna-se uma informação cognitiva prática e acessível no caminho da compreensão dos fatores essenciais à habitabilidade.

\subsubsection{Vênus}

O planeta Vênus dificilmente apresenta condições de habitabilidade em sua superfície. Esta hipótese é fundamentada na estimativa de sua temperatura superficial, que pode alcançar valores entre 400 e $700{ }^{\circ} \mathrm{C}$. Entretanto, com a recente descoberta de bactérias vivendo na estratosfera e na subsuperfície terrestre, torna-se viável a possibilidade da existência de organismos semelhantes habitando as nuvens mais frias, mesmo considerando seu caráter ácido, ou até mesmo o interior do planeta.

\subsubsection{Marte}

A ideia de que o planeta Marte seria habitado por seres extraterrestres estimula a criatividade das pessoas há tempos. O planeta vermelho, apesar de inóspito à maioria dos organismos vivos conhecidos, representa um dos ambientes mais favoráveis a abrigar vida extremófila do Sistema Solar. Porém, condições ambientais extremas, como as baixas temperaturas, a aridez e a ausência de uma atmosfera capaz de gerar proteção contra à radiação, fazem dele um ambiente propício a proliferação de somente alguns dos microorganismos extremófilos terrestres. 
Mesmo com condições geodinâmicas desfavoráveis, há possibilidades de existência de água líquida em Marte (de Pater e Lassauer, 2001) . A constatação de que existem ambientes terrestres onde há crescimento de organismos dentro de filmes finos evidencia a não necessidade da existência de grandes ambientes contendo água líquida para o desenvolvimento da vida. A possibilidade de se encontrar vida em Marte é reforçada ao considerar-se que suas geleiras polares podem abrigar criptoendólitos que vivem e se reproduzem dentro de rochas geladas. Pikuta et al. (2007) sugerem que o aquecimento de origem solar destas rochas (albedos pequenos) proporciona a criação de um filme fino de água líquida, que é responsável por um microambiente constituído por gases, material orgânico e minerais (Cryoconite Ecosystem).

O microorganismo extremófilo talvez mais adaptado a sobreviver na superfície marciana seria a bactéria $D$. radiodurans, que pode suportar e desenvolver-se em ambientes secos, de baixa pressão e expostos a radiação. Caso o planeta Marte apresente uma sub-superfície similar à terrestre, pode existir um gradiente de temperatura originado do decaimento radioativo. Logo, em certa profundidade, a temperatura pode ser propícia para manter a água no estado líquido. Nestes possíveis ambientes, organismos endólitos podem sobreviver confortavelmente.

Estudos recentes apontam para a presença de metano na superfície, oriundo provavelmente da sub-superfície de Marte (Krasnopolsky et al., 2004). Esta constatação abre precedentes para estudos, no sentido de saber se este gás é de origem biológica ou geológica. Entretanto, considerando que o planeta vermelho possui água e basalto, características importantes para o desenvolvimento de ecossistemas microbianos litoautotróficos, pode-se imaginar uma provável colônia de micro-organismos sobrevivendo na subsupefície marciana.

\subsubsection{Os Satélites do Sistema Solar Propensos a Abrigar Vida}

A presença de Satélites orbitando planetas do Sistema Solar é conhecida. Assim, a possível existência de vida nestes corpos e sua confirmação, ainda é um desafio para os cientistas envolvidos em estudos astrobiológicos. 


\subsubsection{Titã}

Titã, satélite de Saturno descoberto em 1655 pelo astrônomo Christiaan Huygens, é a segunda maior lua do Sistema Solar e a única a apresentar uma atmosfera densa. Esse corpo possui energia química abundante na forma de hidrocarbonetos, porém todas as formas de vida conhecidas na Terra, capazes de metabolizar hidrocarbonetos, requerem a presença de oxigênio, que parece ser praticamente ausente em Titã.

Em 1944, Kuiper, por meio de análises espectroscópicas, detectou a presença de metano e apontou para a possibilidade do satélite apresentar uma atmosfera densa. Observações posteriores mostraram a presença de outros hidrocarbonetos, como o etano e o acetileno (Danielson et al., 1973). Somente em novembro de 1980, com as análises oriundas do voo da nave Voyager 1, veio a confirmação da existência de uma densa atmosfera composta principalmente por nitrogênio, seguido de metano (Lindal et al., 1983).

As observações feitas pela nave Huygens, lançada com objetivo de estudar a atmosfera, a superfície e o interior do satélite, confirma que sua atmosfera densa é composta principalmente por $N_{2}(98 \%), \mathrm{CH}_{4}(1,4 \%)$ e $H_{2}(0,1 \%)$; entre os hidrocarbonetos estão o etano $(0,001 \%)$ e o acetileno $(0,0002 \%)$, além dos compostos orgânicos nitrogenados, como o ácido cianídrico (0,00001 \%) (Raulin et al., 2008). A ausência quase que total de oxigênio torna a atmosfera de Titã altamente redutora, sendo o dióxido de carbono $\left(1,6.10^{-7} \%\right)$ e a água $\left(4.10^{-8} \%\right)$ os compostos oxigenados mais abundantes. Na figura $3.4^{10}$ são mostradas algumas das prováveis características da estrutura de Titã e uma comparação entre a superfície da lua e a terrestre.

Apesar da sonda Huygens não ter detectado nenhum sinal de vida macroscópica em Titã, a presença de organismos, mesmo que extremófilos, não pode ser descartada. A ausência de água é um fator limitante ao desenvolvimento da vida como conhecida na Terra, entretanto, a vida em Titã pode estar baseada em solventes não polares distintos da água, como o metano e o etano líquidos. Mesmo que essa possibilidade se mostre inviável, ainda deve ser considerada a existência de alguns solventes polares, como por exemplo a amônia, na superfície, lagos e mares de Titã, que poderiam desempenhar um papel semelhante ao da água na formação de estruturas moleculares (Lunine, 2009).

Estudos conduzidos em laboratórios mostram que gotículas de água imersas em sol-

\footnotetext{
${ }^{10}$ A figura pode ser acessada em: http://photojournal.jpl.nasa.gov/target/Titan.
} 
(a)
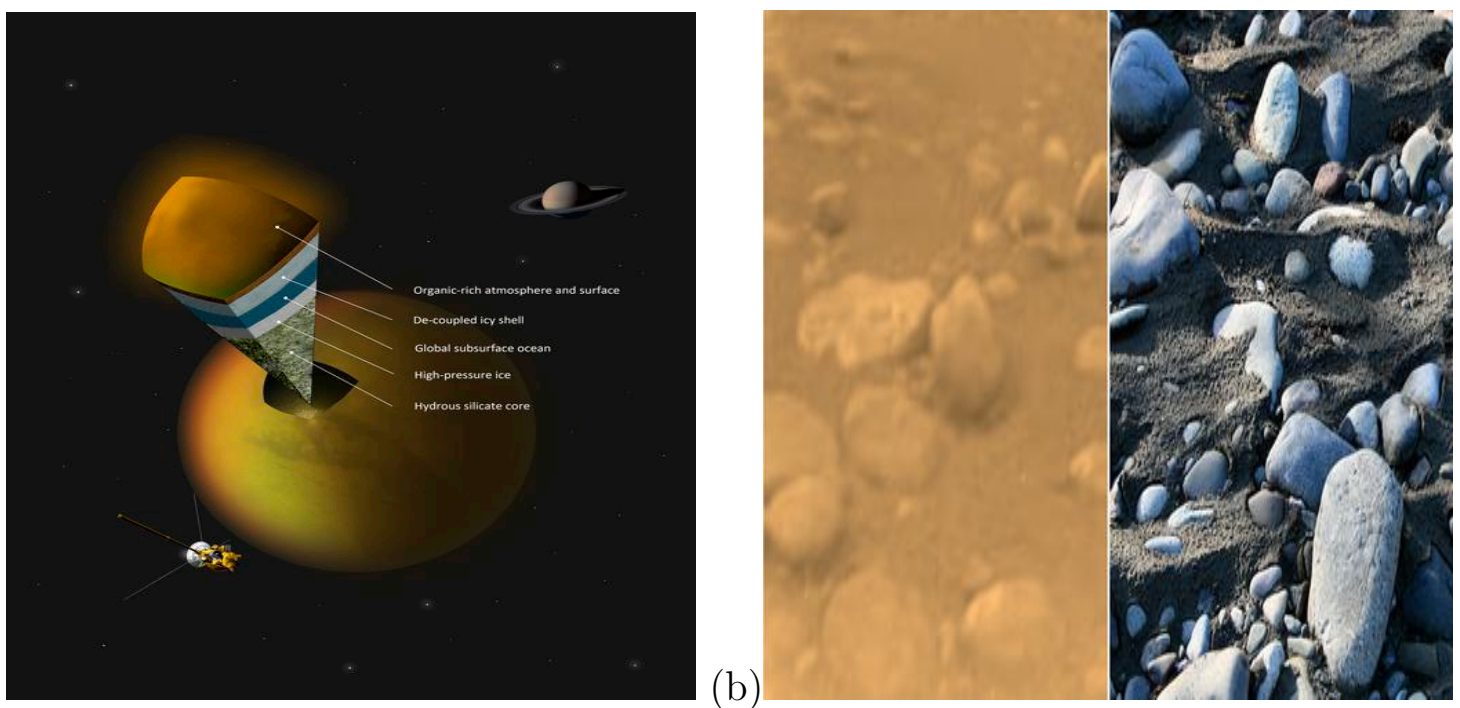

Figura 3.4: Ambientes propensos ao desenvolvimento da vida. (a): concepção artística da possível constituição interna de Titã. Fonte: A. Tavani. (b): comparação entre a superfície da lua Titã e a terrestre. Fonte: NASA/JPL/ESA/University of Arizona and S.M. Matheson. Acesso: 22/08/2012.

ventes hidrocarboníferos formam compartimentos celulares sujeitos à evolução (Tawfik e Griffiths, 1998). Assim, a presença de compartimentos aquosos na subsuperfície de Titã, enriquecidos por hidrocarbonetos, seriam os habitats mais propensos a abrigar vida como observada na Terra (Raulin, 2008). Cálculos realizados por Fortes (2000) sugerem que a energia contida em reservatórios internos seria suficiente para manter um sistema de organismos vivos.

Outro aspecto intrigante advindo dos estudos das caracterísitcas físico-químicas de Titã é a origem do metano em sua superfície e atmosfera. Esta origem poderia estar relacionada à atividade biológica? Caso esta origem fosse biológica, a quantidade de isótopos leves de carbono $\left({ }^{12} C\right)$ deveria ser alta quando comparada a isótopos mais pesados $\left({ }^{13} C\right)$. Na Terra, essa razão $-{ }^{12} C /{ }^{13} C$ - é de aproximadamente 89 e as medidas provindas da sonda Huygens indicam um valor próximo de 82 para Titã (Niemann et al., 2005). Logo, a partir desses resultados, conclui-se que o metano observado em Titã provavelmente não deve ser de origem biológica.

Questionamentos acerca da possibilidade de Titã ser um ambiente propício ao surgimento de uma química pré-biótica e de uma bioquímica baseada em hidrocarbonetos, ainda necessitam de respostas. A possibilidade de vida baseada em solventes líquidos hidrocarbonados pode apresentar algumas caracterísitcas biológicas vantajosas: i) a reatividade orgânica em solventes orgânicos não é menor que na água; ii) os solventes orgânicos são 
mais aptos a formar estruturas supramoleculares a partir de pontes de hidrogênio do que a água; iii) os solventes orgânicos podem ser hidrocarburofóbicos quando associados a moléculas polares, gerando separação de fases, característica importante para o isolamento Darwiniano (Benner e Kim, 2010).

Afirmar que formas de vida podem ter emergido e ainda manter-se em Titã é prematuro. Entretanto, caso estudos e missões futuras comprovem tal hipótese, ratificar-se-á a ideia de que a vida pode se desenvolver por caminhos e processos distintos dos observados na Terra e, além disso, concluir que a vida pode ser bastante comum no universo.

\subsubsection{Europa}

As primeiras observações do Satélite de Júpiter, Europa, foram realizadas em 1610 por Galileo Galilei e Simon Marius. Em 1979, as sondas espaciais Voyager 1 e 2 obtiveram dados detalhados da superfície coberta de gelo e indícios do provável oceano de água líquida na sub-superfície do satélite. Entre os anos de 1995 e 2003, a espaçonave Galileo, equipada com câmeras telescópicas de $1500 \mathrm{~mm}$, polarímetros fotométricos, espectrômetros UV, magnetrômetros, entre outros aparatos tecnológicos, orbitou Júpiter e revelou detalhes dessa lua.

O raio de Europa foi estimado em $1565 \mathrm{~km}( \pm 8 \mathrm{~km})$ e sua temperatura média superficial em 103 K. Sua superfície, coberta por gelo, apresenta certa suavidade, contrastada com cúpulas, fraturas, poços e rachaduras provocadas por forças de marés, que podem permitir o contato da água de seu interior com a superfície externa, além de poucas crateras, indicando a renovação de sua superfície em intervalos de tempo entre 30 - $70 \mathrm{Ma}$ (milhões de anos) (Figueredo e Greeley, 2004). A lua parece ter um casca interna de rocha/metal de densidade maior que $3800 \mathrm{~kg} \cdot \mathrm{m}^{-3}$, sobreposta por uma camada de água (de densidade aproximada de $1000 \mathrm{~kg} \cdot \mathrm{m}^{-3}$ ) em estado sólido ou talvez em estado líquido (Anderson et al., 1998). Europa deve possuir um núcleo metálico comparado à metade de seu raio e camadas de água de espessura entre 80 e $170 \mathrm{~km}$. As análises de dados provenientes da sonda Galileo apontam para existência de um campo magnético próximo à superfície de Europa. Essa componente superficial de campo magnético sugere a presença de um fluido iônico (água salgada) que se comporta como material indutor. 
Na figura $3.5^{11}$ são mostrados a provável estrutura da lua, assim como alguns aspectos de sua superfície.
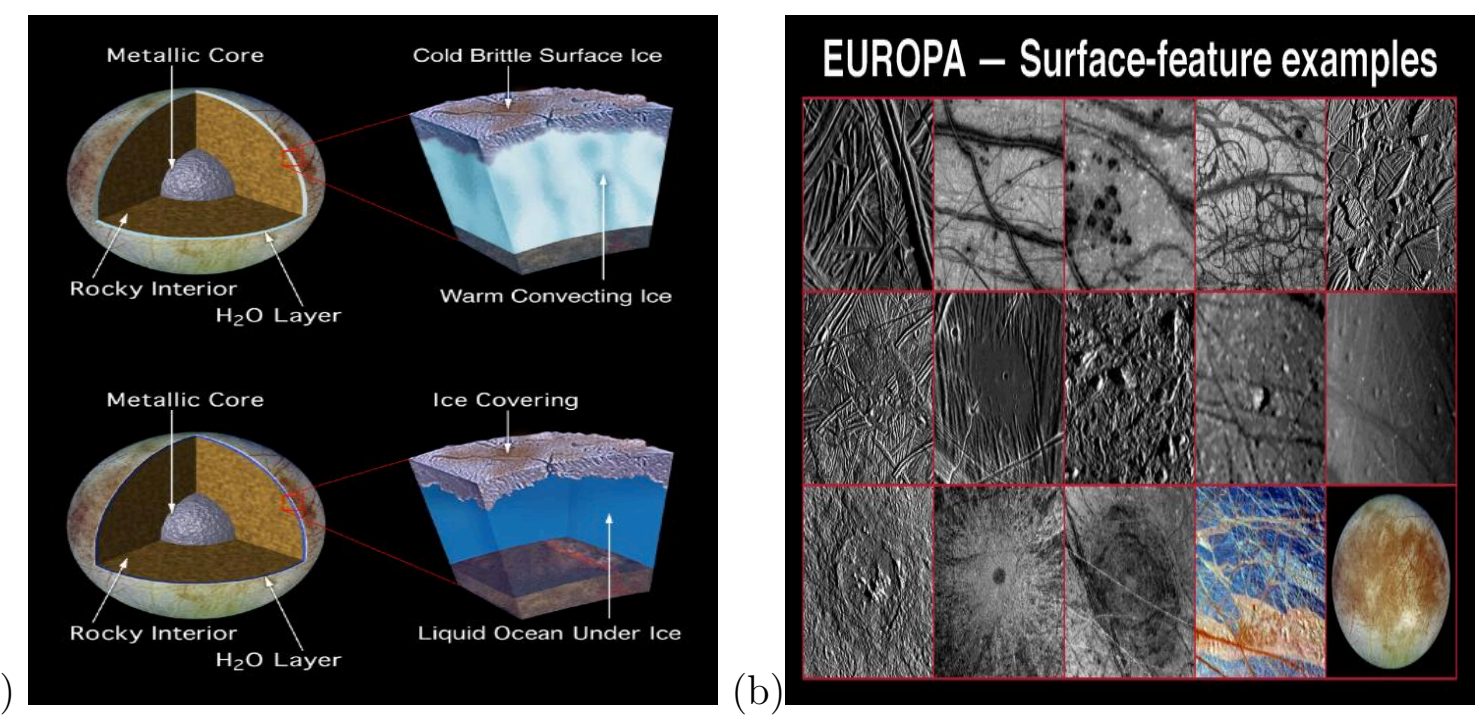

Figura 3.5: Características do satélite natural Europa. (a): concepção artística de duas possíveis constituições de Europa. A primeira, mostra uma camada de gelo aquecido por convecção a vários quilometros da superfície; a segunda, retrata a existência de um oceano de água líquida abaixo da superfície congelada da lua. Fonte: NASA/JPL. (b): vários aspectos da superfície da lua. Fonte: NASA/JPL/DLR.

Materiais diferentes do gelo podem existir na superfície do satélite (Denk et al., 1998), em lugares onde havia se pensado existir somente água, levando à hipótese de que o oceano sub-superficial pode ser composto por diferentes componentes de gelo e interagir com a superfície ou de que esse material tenha sido entregue por meio de cometas, poeira interplanetária e meteoritos, que teriam bombardeado a superfície da lua. Há evidências espectrais sinalizando para a presença de materiais como o enxofre, o ferro, alguns sulfetos, compostos carbonados, etc. Todavia, nenhum deles foi observado ou confirmado de maneira contundente; além disso, caso realmente seja real essa existência, ainda permanecerão dúvidas quanto às suas nutureza e origem.

A grande questão a ser respondida é se Europa pode sustentar vida. Sistemas hidrotermais podem existir no oceano sub-superficial da lua e garantir uma fonte alternativa de energia para o desenvolvimento da vida de micro-organismos termófilos quimiossintetizantes ou até mesmo organismos multicelulares que se alimentam desses micróbios, assim como é observado em alguns ambientes terrestres. Porém, a acidez e as baixas temperaturas podem tornar-se barreiras às reações químicas necessárias ao metabolismo celular da

\footnotetext{
${ }^{11}$ A figura pode ser acessada em: http://www.jpl.nasa.gov/galileo/sepo/. Acesso: 22/08/2012.
} 
maioria dos organismos. Entretanto, caso não haja ventos hidrotermais, a vida ainda pode surgir, utilizando-se da energia contida na interface de rochas-água, como é encontrado em profundos aquíferos terrestres (SLiME); já na superfície do satélite, podem existir ambientes similares à Antártica (temperaturas próximas de $230 \mathrm{~K}$ ), onde organismos psicrófilos vivem (Price e Sowers, 2004). Deve-se considerar ainda o bombardeamento por meio dos ventos solares e pelas particulas carregadas da magnetosfera joviana ao qual o satélite está exposto devido a ausências de condições geomagnéticas e atmosféricas de proteção, causando a destruição de moléculas orgânicas; estudos mostram que a radiação eletromagnética ótima para o desenvolvimento fotossintético pode penetrar alguns metros em direção ao interior, através de aberturas na superfície da lua, onde os micro-organismos podem estar protegidos de danos e utilizarem essa fonte de energia para desenvolver-se (Phillips e Chyba, 2001; Marion et al., 2003).

A figura $3.6{ }^{12}$ retrata o possível sistema hidrotermal e a provável conexão do conteúdo oceânico da lua com a sua superfície.

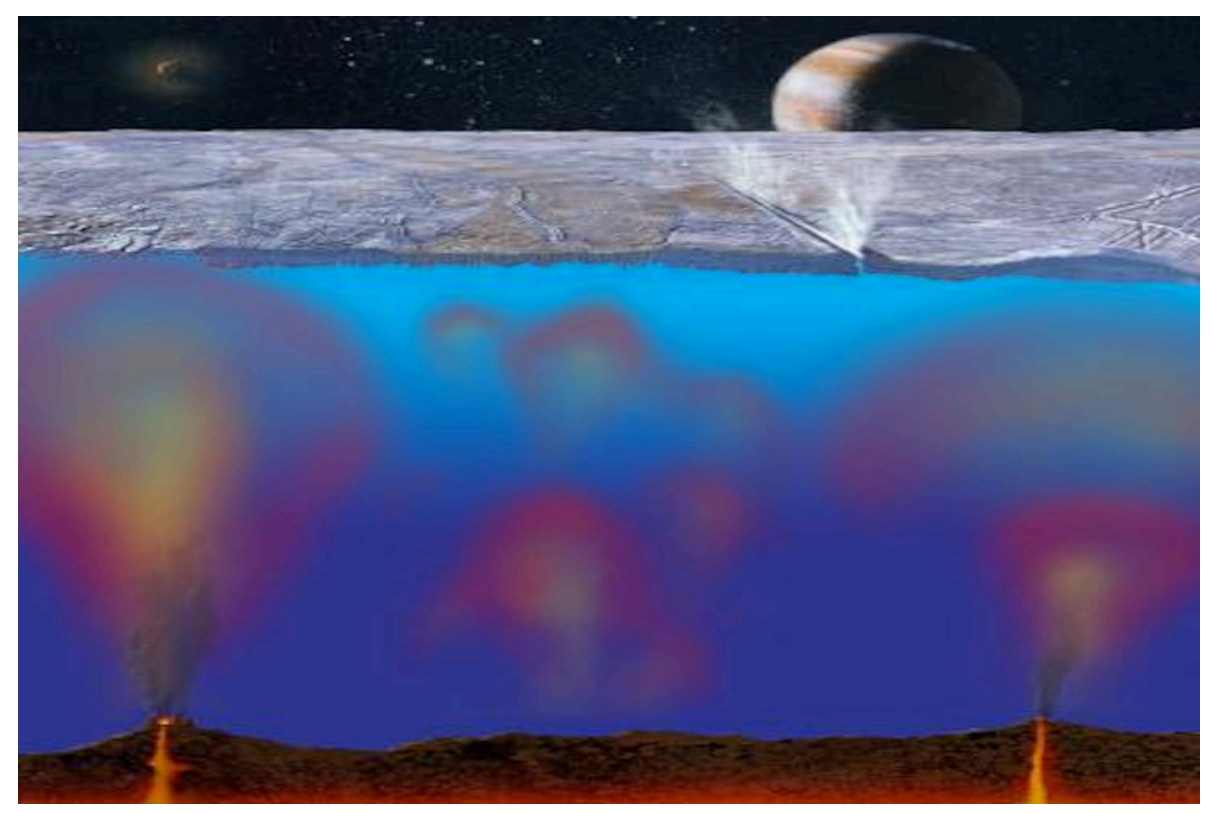

Figura 3.6: Sistemas hidrotermais ativos e a provável conexão do conteúdo oceânico da lua com a sua superfície. Fonte: NASA/JPL.

Assim, o satélite Europa, torna-se um grande laboratório de pesquisas e um dos alvos principais na busca de vida extraterrestre.

12 A figura pode ser acessada em: http://photojournal.jpl.nasa.gov/catalog/PIA10131. Acesso: $22 / 08 / 2012$. 


\subsubsection{Io}

O satélite de Júpiter, Io, possui temperaturas variando em uma faixa de -130 a $2000{ }^{0} C$ e sua superfície apresenta geysers e fontes ácidas (de Pater e Lassauer, 2001). Ambientes terrestres anaeróbicos similares aos dessa lua são encontrados também em geysers, regiões vulcânicas, ventos hidrotermais, rochas profundas da crosta terrestre, aquíferos profundos, lagos de soda e lagos de alta salinidade. Essas regiões são aptas a abrigarem microorganismos acidófilos litotróficos que são capazes de metabolizar enxofre. O enxofre é uma fonte viável de energia para muitas bactérias e arqueas, que eliminam $\mathrm{H}_{2} \mathrm{~S}$ como produto final de seu metabolismo.

Acredita-se que o satélite Io possa ejetar e transferir enxofre e outros materiais diretamente para a lua Europa, servindo como fonte de compostos biogênicos (Alvarellos, 2008). Essa transferência ocorre devido à liberação do enxofre oriundo do processo de vulcanismo, que é transportado pela magnetosfera de Júpiter até a superfície de Europa. Logo, esse objeto também torna-se importante na formulação de hipóteses relacionadas à tranferência de materias essenciais ao desenvolvimento da vida.

\subsubsection{Enceladus}

Em março de 2006, o minúsculo satélite de Saturno, Enceladus, tornou-se o novo objeto candidato a abrigar vida no Sistema Solar (Porco et al., 2006). A missão Cassini revelou uma nuvem de oxigênio no anel externo de Saturno, o E ring, e Enceladus é a provável fonte desse gás. Acredita-se que essa lua, além de possuir uma fonte interna de aquecimento, também possa ser geologicamente ativa, apresentando ambientes com geysers frios que lançam vapor de água e gelo ao meio exterior. A decomposição da água líquida, que provavelmente está armazenada em seu interior, seria a fonte dessas nuvens. Logicamente, onde há água existe boa probabilidade de existência de vida.

\subsection{Sobrevivência de Organismos no Espaço}

Ambientes espaciais são muito severos à vida, devido ao alto vácuo, à intensa radiação provinda da galáxia e do Sol, assim como aos valores extremos de temperaturas. Estudar a maneira pela qual os organismos podem se adaptar às condições extremas presentes na 
alta atmosfera e no espaço, fornece fortes subsídios para a possível sustentação da hipótese da panspermia através de extremófilos. Muito dos estudos realizados com esses organismos foram feitos através de experimentos in situ dentro de balões, foguetes e espaçonaves, como a Gemini, Apollo, Spacelab, etc ... (Horneck, 1993).

No meio interplanetário, são encontrados valores de pressão abaixo de $10^{-19}$ bars, porém na baixa órbita da Terra, onde grande parte dos experimentos com micro-organismos foram realizados, encontram-se pressões da ordem de $10^{-9}-10^{-11}$ bars. Alguns experimentos demonstram que certos organismos podem sobreviver por longos períodos quando expostos ao vácuo espacial, porém protegidos da intensa radiação UV de origem solar. Os esporos da bactéria Bacillus subtilis, quando protegidos da radiação, puderam sobreviver por um período de 6 anos no espaço (Horneck et al., 1994); este tempo pode ser superior, caso tais esporos ganhem proteção extra de múltiplas camadas ou sejam colocados na presença de glicose. O material genético dos esporos sobreviventes à exposição espacial sofreu danos que foram evidenciados pela observação do aumento na taxa de mutação, do atraso no processo de germinação, das quebras de cadeias de DNA, entre outras. Os danos celulares provavelmente foram ocasionados pela desidratação dos esporos quando expostos a alto vácuo. Este cenário traz severas consequências para a estabilidade e funcionalidade das membranas e macromoléculas presentes na estrutura celular (Horneck et al., 1994).

Organismos expostos a ambientes espaciais entram em contato com ampla faixa de radiação eletromagnética de origem solar (desde curtos comprimentos de ondas - raios x - a comprimentos maiores, como os de radio frequência). A aproximadamente uma $U A$ de distância, o fluxo de radiação solar é de $1360 \mathrm{~W} \cdot \mathrm{m}^{-2}$, sendo que a maior parte desta radiação corresponde à porção visível do espectro (48 \%), seguido do infravermelho (45 \%) e do UV (7\%). Sabe-se que a radiação UV é um dos fatores mais limitantes à sobrevivência de organismos como vírus, bactérias e esporos no espaço (Horneck, 1992; Horneck, 1993; Horneck et al., 1994). A exposição à radiação UV em comprimentos acima de $170 \mathrm{~nm}$ é praticamente letal ao esporo da bactéria Bacillus subtilis. O mesmo efeito não é observado na Terra, pois a camada de ozônio protege a biosfera da maior parte da radiação UV nociva (comprimentos de onda menores que $295 \mathrm{~nm}$ ). Este efeito de proteção da camada de ozônio em relação à radiação UV foi comprovada experimentalmente (Horneck et al., 1996). 
O campo de radiação ao qual os planetas do Sistema Solar está exposto é de origem galática e solar. A radiação cósmica da galáxia é composta basicamente de prótons (85 \%), elétrons, partículas alfas (14\%) e íons pesados (1\%). As partículas provenientes do Sol, durante a ocorrência de ventos ou flares solares, é constituída principalmente por prótons (a maior fração), partículas alfa e poucos íons pesados. O planeta Terra é protegido pelos cinturões de radiação - locais onde as partículas (prótons e elétros) ficam aprisionadas originados pelo campo geomagnético, que é uma condição essencial para a habitabilidade do planeta (vide capítulo 4).

Os íons pesados são as espécies ionizantes que mais efetivamente danificam os sistemas biológicos. Buecker e Horneck (1975) propuseram experimentos com o objetivo de avaliar a interação destas partículas com sistemas biológicos tais como vírus, esporos de bactéria, sementes de plantas, cistos de camarão, etc; foram observadas lesões como mutações somáticas nas sementes das plantas, desenvolvimento de distúrbios e má formação em insetos e embriões de camarões, além da inativação de esporos bacterianos. Logo, considerando que partículas de raios cósmicos tornam-se um limite à sobrevivência de esporos no espaço, já que estas penetram facilmente blindagens biológicas, estimou-se em $10^{5}-10^{6}$ anos o tempo máximo ao qual um esporo pode permanecer intacto frente à ação das partículas ionizantes pesadas.

Em locais próximos à órbita terrestre, a temperatura de um corpo atinge valores extremos. Um organismo submetido às condições espaciais e blindado da radiação térmica solar estará exposto a temperaturas da ordem de $4 K$; nestas condições, as reações químicas e os processos termodinâmicos são praticamente inexistentes. Experimentos em laboratório têm sido planejados com o intuito de simular as condições encontradas no meio interestelar e os resultados apontam para um menor efeito danoso da radiação UV em sistemas biológicos, quando expostos a baixas temperaturas. O esporo do organismo B. subtilis foi submetido a radiação UV de comprimento de onda superior a $110 \mathrm{~nm}$, ao vácuo e a temperatura de $10 K$, demonstrando uma alta taxa de sobrevivência (Weber e Greenberg, 1985). Uma estimativa conduzida por Weber e Greenberg (1995) demonstra que um esporo pode sobreviver centenas de anos submetidos a condições espaciais. Deve-se considerar ainda os organismos tardígrados que, como mencionado anteriormente, suportam condições extremas de temperatura, pressão e exposição à radiação; essas habilidades podem fazer 
desse organismo um dos principais candidatos a sobrevivência em uma possível viagem interplanetária.

\subsection{Extremófilos e Panspermia}

Poderia um organismo extremófilo sobreviver a uma viagem interplanetária? É difícil confirmar o fato de que micro-organismos possam atravessar o inóspito espaço interplanetário, mas análises do meteorito marciano ALH 84001 (McKay et al., 1996), apontam para uma possível existência de fósseis enclausurados nele e esta possibilidade reacende o debate em torno do tema referente às jornadas interplanetárias.

Uma possível viagem interplanetária segue necessariamente alguns passos. Primeiro, o material biológico deve ser conduzido ao espaço através de um processo de escape, que inicia-se na superfície em direção às altas altitudes. Em seguida, este material estando no espaço, necessita sobreviver a escalas de tempo próximas as das jornadas interplanetárias. Por último, o material biológico deve suportar as condições físicas impostas pelo processo de reentrada no planeta ou satélite de destino.

É bem provável que a ejeção de pequenas partículas ou até mesmo pedregulhos rumo ao espaço seja possível ao se considerar impactos de grandes meteoritos na superfície de planetas ou satélites, fonte do material biológico. Esporos bacterianos podem sobreviver a impactos produzidos por meteoritos e também às condições espaciais extremas. Uma viagem entre o planeta Marte e a Terra tem duração aproximada de $10^{6}$ anos, considerando objetos com dimensões de pedregulhos, porém partículas microscópicas mostram ser aptas a percorrer o mesmo percurso em poucos meses.

Os cometas poderiam transportar compostos essenciais ao desenvolvimento da vida ou até mesmo materiais biológicos para planetas e luas? Modelos teóricos e observações do núcleo do cometa $P /$ Halley indicam que a temperatura interna em determinadas regiões do objeto pode variar em uma faixa ampla de temperatura. Os organismos psicófilos não são aptos a colonizarem ambientes com variação brusca de temperatura, já que esses não sobrevivem a temperaturas elevadas, porém há organismos capazes de sobreviver a variações maiores de temperatura, salinidade, $\mathrm{pH}$, concentrações de enxofre e sulfatos: as diatomáceas (formas eucarióticas), vários tipos de cianobactérias, bactérias que metabolizam o ferro e o enxofre, além de algumas arqueas. Em 1980, Hoyle e Wickramasinghe 
propuseram a hipótese de que bactérias poderiam se proteger da radiação e sobreviver dentro de cometas. Eles estimaram que a Terra recebe mais de $10^{8}$ células por ano provenientes do espaço e ainda mostraram que o espectro infravermelho do cometa Hale-Boppe era uma excelente combinação de uma cultura mista composta por bactérias, diatomáceas e olivina, em comprimentos de onda na faixa $8-40 \mu m$. Sabe-se que esses organismos apontados pelos cientistas como aptos a habitarem os cometas, sobrevivem em filmes finos de água e em ambientes criogênicos (Hoover et al., 2004).

A contaminação planetária por micro-organismos extremófilos é um cenário plausível. Paulino-Lima et al. (2011), conduziram vários experimentos com a bactéria D. radiodurans com a finalidade de testar a hipótese da micropanspermia. Foram simulados vários cenários onde a bactéria esteve exposta a diferentes fontes de radiação que reproduziram sua provavél interação, em uma possível viagem através do meio interplanetário, com algumas partículas que compõem o vento solar: prótons, elétrons e íons de carbono. Eles concluíram que as células desprotegidas da bactéria radiodurans são aptas a suportarem campos de radiação com energia equivalente à faixa de $2-4 \mathrm{keV}$, em uma distância orbital de $1 U A$ (distância entre a Terra e o Sol), por um período de mil anos. Porém, $90 \%$ dessas células quando expostas a campos de radiação iônicos com energia da ordem de 200 $k e V$, compatíveis com ejeções solares, podem tornarem-se inativas em períodos menores do que um ano (a distâncias equivalentes a $1 U A$ ). Observou-se um aumento aproximado de dez vezes na taxa de sobrevivência, quando essas células foram colocadas em contato com grãos de poeira constituídos por minerais que apresentavam composições químicas semelhantes às encontradas no meio circunstelar $\left(\mathrm{Mg}_{2} \mathrm{SiO}_{4}\right.$ e $\left.\mathrm{Fe}_{2} \mathrm{SiO}_{4}\right)$, mostrando que ambientes desse tipo são propícios a serem vetores em uma possível viagem interplanetária. Micro-organismos sob grãos de poeira protegidos da radiação UV, responsáveis por danos severos ao material biológico, também serão protegidos do campo de radiação de partículas carregadas (Paulino-Lima et al., 2010;2011).

Logicamente, a hipótese de panspermia via extremófilos necessita de outras experiências e teorias para ser ratificada. Entretanto, como será demostrado posteriormente, planetas e satélites, localizados dentro de certas distâncias orbitais em torno de suas estrelas hospedeiras (Zona Extremófila), podem abrigar o material biológico necessário à possível dissiminação da vida através do espaço. 
Capítulo 4

\section{Habitabilidade}

A zona habitável de um sistema planetário está localizada em uma região particular do meio interestelar, onde há estrelas propícias a oferecer condições otimizadas de habitabilidade. Lineweaver et al. (2004) modelaram a evolução da galáxia baseados na taxa de formação estelar, na metalicidade, no tempo de evolução e em locais onde há probabilidade de grandes surtos de Supernovas. Todos esses parâmetros definem restrições à existência de sistemas planetários aptos a sustentar vida. A figura 4.1 mostra o estudo dessas localidades e nota-se claramente que apenas uma região particular é favorável a sustentar processos que podem levar ao surgimento da vida como observa-se na Terra (região verde).

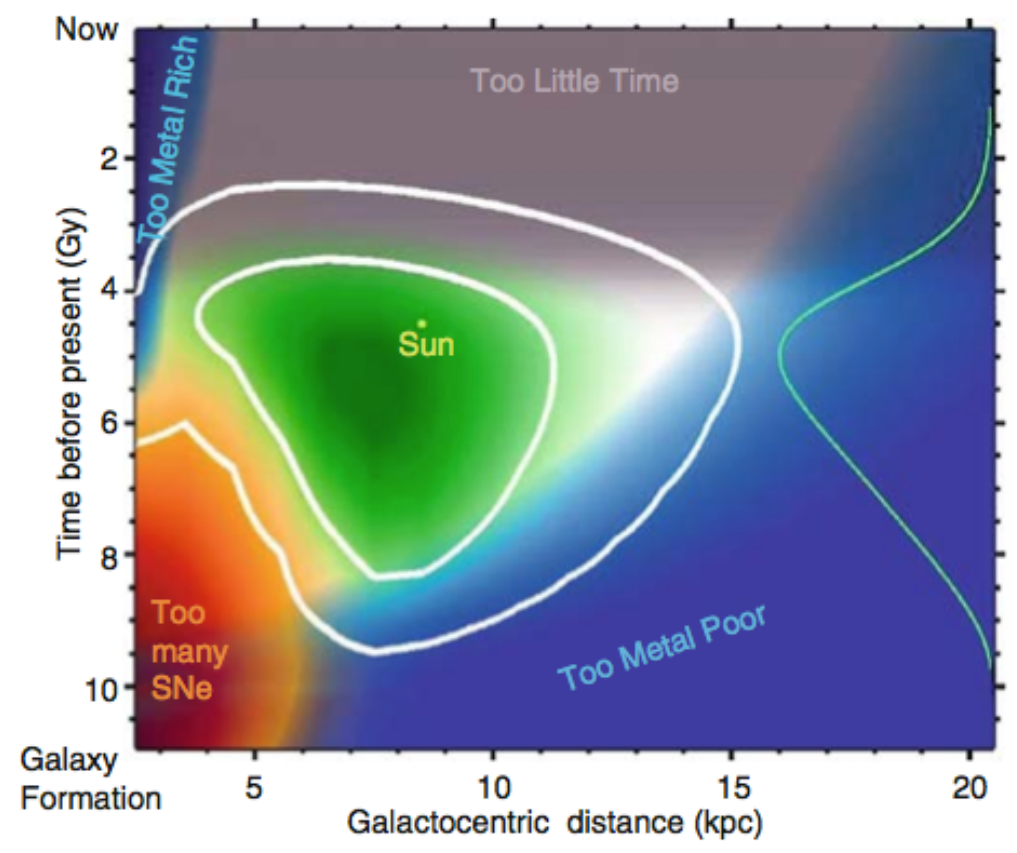

Figura 4.1: Zona Habitável Galáctica para o disco da Via Láctea. Fonte: Lineweaver et al. (2004). 
Em astronomia, Zona Habitável (ZH) é a coroa esférica em torno da estrela central de um sistema planetário, onde as condições físicas permitem a existência de água líquida. Planetas e seus satélites nessas regiões são pois, em princípio, habitáveis, em termos do tipo de vida corrente no planeta Terra.

Essa afirmativa se baseia no fato de que existe vida na Terra, em todos os lugares onde existe água líquida, não importando as condições físicas prevalecentes. A descoberta da vida extremófila mostrou que, na procura de seres vivos extraterrestres, é necessário ampliar o conceito de ZH, estendendo-o a outro mais amplo, o de Zona Extremófila (ZE) (Janot-Pacheco et al., 2009). A posição e extensão da ZH ou ZE depende da temperatura na superfície do planeta ou satélite, ou seja, depende entre outros fatores, do raio da órbita planetária e do tipo espectral da estrela. Sua posição varia também no tempo, na medida em que a estrela evolui (Kasting et al., 1993). A ZH do Sistema Solar está centrada atualmente acerca de uma $U A$ do Sol. Por exemplo, para estrelas com 0,25 e duas vezes a luminosidade solar, a ZH estará próxima de 0,5 UA e 1,4UA das estrelas centrais respectivamente.

No capítulo 7, será apresentado o planeta que foi descoberto em torno da estrela Gliese 581 (Gliese 581d), que é uma anã vermelha. Apesar de seu período orbital ser aproximadamente de 63 dias, ele encontra-se na $\mathrm{ZH}$, sendo o exemplo de exoplaneta mais favorável à existência potencial de vida em sua superfície descoberto até poucos anos, já que o planeta GJ $667 C c$, parece superar as expectativas de habitabilidade apresentadas pelo planeta GL $581 d$.

\subsection{Breve Histórico}

O interesse pela pesquisa de vida extraterrestre estimula os esforços da comunidade científica há décadas. A região em torno da estrela hospedeira de um sistema planetário a qual oferece condições mínimas para o desenvolvimento da vida foi denominada Zona Habitável (Huang 1959, 1960) ou Ecosfera (Dole, 1964). O critério, baseado em parâmetros físico-químicos, utilizado na definição dos limites dessa posição orbital ótima para a proliferação da vida sofreu alterações com o passar dos anos: a Zona Habitável idealizada por Dole foi pensada em termos das condições de sobrevivência humanas, ou seja, um planeta habitável deveria apresentar temperaturas superficiais médias, não excedendo os extremos 
de $-10-40{ }^{0} C$; Hart (1978), Rasool e DeBergh (1970), Kasting et al. (1988) e Whitmire et al. (1991), associaram o conceito de Zona Habitável à presença de água líquida na superfície do planeta; Fogg (1992) utilizou as ideias contidas nas duas definições e propôs o termo biocompatibilidade, referindo-se a planetas que possuem um reservatório de água líquida e utililizando o termo habitável especificamente para objetos que fossem favoráveis à sobrevivência de seres humanos.

Outros modelos mais complexos foram desenvolvidos com a finalidade de impor limites mais precisos a essa definição. Verifica-se que o modelo de Dole caracteriza a Zona Habitável como uma região em torno do Sol que se estende de 0,725UA a 1,240UA. Esse resultado, entretanto, é obtido ao se considerar a atmosfera terrestre opticamente fina e fixando o albedo planetário; este cenário ignora o fato de que a atmosfera terrestre é espessa a maior parte da radiação infravermelha, o que gera um efeito estufa importante, além da variação do albedo planetário.

O modelo atmosférico utilizado por Kasting et al. (1993), define os limites interno e externo da Zona Habitável do Sistema Solar em posições orbitais iguais a 0,95 UA e 1,37 $U A$ respectivamente; a Zona Habitável definida por esse modelo leva em consideração o início da perda de água via fotólise, para a determinação do limite interno, e o início de formação de nuvens de $\mathrm{CO}_{2}$ na especificação do limite externo. Forget e Pierrehumbert (1997) e Mischna et al. (2000), argumentam que planetas com alta concentração de $\mathrm{CO}_{2}$ em suas atmosferas apresentam um efeito de aquecimento adicional, estendendo o limite externo da Zona Habitável a valores próximos de 2,40 UA. O modelo de Franck et al. (2001), estipula seus limites, interno e externo, para a Zona Habitável com dois parâmetros físicos: a temperatura e a pressão atmosférica parcial de $\mathrm{CO}_{2}$. Assim, o limite interno é caracterizado por posições orbitais onde se encontram valores de pressão de $10^{-5}$ bars e de

temperatura de $273 \mathrm{~K}$, e o limite externo, com valores de $10^{-5}$ bars e $373 \mathrm{~K}$; logo, a Zona Habitável desse modelo se estende de 0,95-1,20 UA.

\subsection{Aspectos Gerais sobre o Conceito de Habitabilidade}

A Zona Habitável pode ser definida de forma mais precisa como a região em torno de uma estrela hospedeira onde sua luminosidade é suficientemente intensa para manter água líquida na superfície de planetas ou luas, sem iniciar o processo de runaway greenhouse 
(Kasting, 1998). Em um cenário que visa a busca por vida extraterrestre é esperado que o reservatório de água líquida se mantenha por bilhões de anos, pois esse seria provavelmente o tempo necessário para o desenvolvimento da vida e do equilíbrio atmosférico.

O efeito estufa é o mecanismo responsável pela manutenção da temperatura superficial do planeta ou lua acima do valor de sua temperatura efetiva, sendo o ciclo do $\mathrm{CO}_{2}$, o principal termo-regulador do clima de planetas terrestres. A temperatura efetiva do planeta pode ser obtida pela equação:

$$
T_{e f f}=\frac{(1-A)^{\frac{1}{4}} T_{s}}{\sqrt{2}}\left(\frac{R_{s}}{a_{p}}\right)^{\frac{1}{2}}
$$

Essa temperatura de corpo negro possui dependência com parâmetros estelares como a temperatura, $T_{s}$, o raio, $R_{s}$, e a distância estrela-planeta, $a_{p}$, além do albedo planetário. A temperatura efetiva terrestre é estimada em $250 \mathrm{~K}$, valor abaixo da temperatura superficial real que é de aproximadamente $288 \mathrm{~K}$. Na busca de vida que utiliza a água como solvente, identificar regiões propícias a abrigar objetos que possam manter gases capazes de gerar um efeito estufa eficiente é essencial.

\subsection{Ciclo Silicato-Carbono}

O termo habitabilidade foi criado a fim de descrever processos físico-químicos necessários para que a temperatura superficial de um planeta ou lua permaneça acima de 273 $K$ por intervalos de bilhões de anos. A interação entre radiação estelar e a estabilidade climática está intimamente relacionada com o ciclo de silicato-carbono, através de um mecanismo de feedback no qual o dióxido de carbono é o gás mais importante para o efeito de aquecimento superficial do planeta. A concentração parcial de $\mathrm{CO}_{2}$ é inversamente proporcional à temperatura superficial do planeta (Kasting, 1993).

Gases como o $\mathrm{CO}_{2}$, metano e o vapor de água, conhecidos como gases de efeito estufa, são praticamente transparentes à passagem da radiação na faixa visível do espectro eletromagnético, porém bloqueiam de forma eficiente a radiação infravermelha, termalizando a energia solar após sua interação com a superfície planetária. A interação entre a radiação solar que atinge o planeta e seu conteúdo de dióxido de carbono é evidenciada pela intensidade do processo de intemperismo, ou seja, a concentração de $\mathrm{CO}_{2}$ diminui 
proporcionalmente ao aumento do fluxo radioativo.

Determinada concentração inicial de $\mathrm{CO}_{2}$ na atmosfera condiciona uma certa temperatura superficial. Entretanto, a atividade vulcânica pode injetar uma maior quantidade do gás a essa concentração inicial e consequentemente elevar a temperatura superficial do planeta. Este aumento de temperatura intensifica o mecanismo de intemperismo, que acontece através da erosão de rochas, pela ação direta da temperatura ou pelo aumento de pluviosidade. Os materiais rochosos (silicatos) interagem com esse ambiente rico em dióxido de carbono através de reações de oxidação e o gás é removido da atmosfera, combinando-se em sedimentos minerais carbonados que são transportados em direção aos oceanos, onde organismos os utilizam para construir suas conchas, por exemplo (Kasting, 1993):

$$
\begin{gathered}
\mathrm{CaSiO}_{3}+2 \mathrm{CO}_{2} \rightarrow \mathrm{Ca}^{++}+2 \mathrm{HCO}_{3}^{-}+\mathrm{SiO}_{2} \\
\mathrm{Ca}^{++}+2 \mathrm{HCO}_{3}^{-} \rightarrow \mathrm{CaCO}_{3}+\mathrm{CO}_{2}+\mathrm{H}_{2} \mathrm{O} \\
\mathrm{CaSiO}_{3}+\mathrm{CO}_{2} \rightarrow \mathrm{CaCO}_{3}+\mathrm{SiO}_{2}
\end{gathered}
$$

O material escoado ao fundo do oceano pode retornar à atmosfera através da movimentação de placas tectônicas. Esse processo ocorre porque tais movimentações transportam esses sedimentos a regiões de subducção, onde são dissolvidos com a liberação do dióxido de carbono, que retorna à atmosfera por meio de vulcanismo. A figura 4.2 mostra de forma coerente as principais etapas do ciclo do silicato-carbono. 


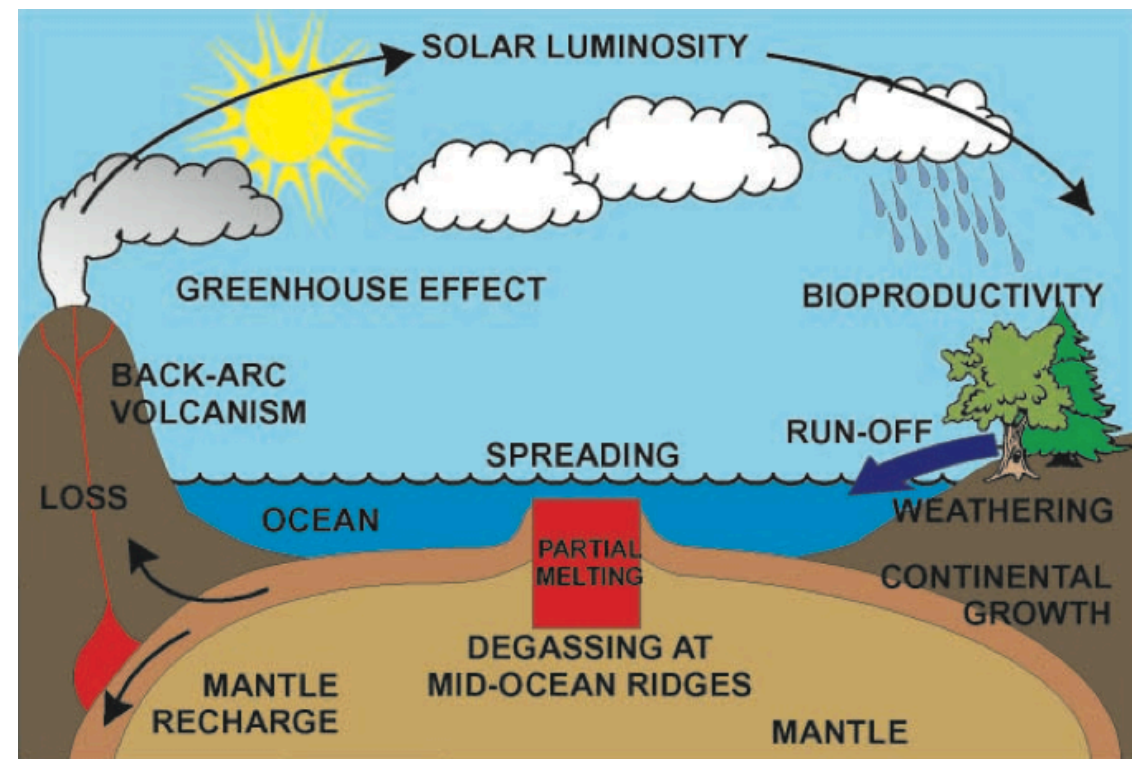

Figura 4.2: Representação do ciclo silicato-carbono terrestre global. Fonte: Franck et al. (2001).

Fluxos radioativos intensos aumentam a temperatura supercial do planeta e, consequentemente, interferem na remoção do dióxido de carbono da atmosfera, cujo objetivo é a redução desse parâmetro físico. Ao contrário, se a reposição do conteúdo de $\mathrm{CO}_{2}$ presente na atmosfera não for eficiente, sua concentração diminui, assim como a temperatura superficial e a intensidade do processo de intemperismo; a queda dessas duas últimas variáveis permite a restauração do $\mathrm{CO}_{2}$ atmosférico, caso a frequência das atividades vulcânicas sejam normais.

Nota-se que o completo desenvolvimento do ciclo é um processo que ocorre em uma escala de tempo de bilhões de anos e é dependente do fluxo interno de calor capaz de alimentar atividades vulcânicas. Entretanto, o ciclo de silicato-carbono pode ser afetado por dois fenômenos físico-químicos: alta concentração de vapor de água na atmosfera e a formação de nuvens de $\mathrm{CO}_{2}$ a baixas altitudes. O primeiro fenômeno ocorre quando altas temperaturas superficiais aumentam a evaporação da água contida na superfície do planeta, resultando em uma elevada concentração de água na atmosfera. As nuvens de água intensificam o efeito estufa, gerando um mecanismo de retroalimentação positivo, ou seja, o mecanismo de remoção de dióxido de carbono da atmosfera para o controle da temperatura superficial do planeta é desbalanceado. Já o segundo fenômeno, está relacionado com a formação de nuvens de $\mathrm{CO}_{2}$ ou até de vapor de água, que contribui 
para o aumento do albedo planetário. $\mathrm{O}_{\mathrm{CO}_{2}}$, quando submetido a baixas temperaturas, condensa e forma nuvens que refletem a radiação solar. Consequentemete, em um estágio posterior, a temperatura do planeta será ainda mais reduzida, resultando em um aumento da concentração de dióxido de carbono na atmosfera; esse mecanismo poderá conduzir o planeta a uma glaciação completa e impossibilitar a presença de água líquida em sua superfície.

\subsection{Limite Interno da Zona Habitável (Baseado na Observação do Sistema Solar)}

Planetas do tipo terrestre localizados no limite interno da Zona Habitável, portanto mais próximos à estrela hospedeira, podem passar por um processo de vaporização de seus reservatórios superficiais de água líquida. Esse processo aumenta o nível de vapor de água na atmosfera e produz um efeito estufa mais efetivo, seguido de um aumento da temperatura superficial média do planeta, conduzindo a atmosfera a um estado de umidade maior. Um aumento na umidade atmosférica implica em um resfriamento superficial por meio do fenômeno de convecção, responsável pela manutenção dos reservatórios de água superficiais em algumas ocasiões.

Em temperaturas superficiais próximas a $370 K$ (aproximadamente a 0,95 UA), o vapor de água já é um dos principais constituintes da atmosfera a altitudes elevadas, com exceção da camada mais alta, onde a água é dissociada em hidrogênio e oxigênio pela ação da radiação UV. Em distâncias orbitais pequenas, a quantidade de vapor de água na atmosfera é considerável, e a energia emitida pelo planeta no espectro infravermelho atinge um platô, caracterizado por uma temperatura superficial de $550 \mathrm{~K}$, devido à alta opacidade de uma atmosfera composta predominantemente por água. A zona onde a emissão térmica acontece é deslocada na direção de uma região radiativa isotérmica a altas altitudes, onde não sofre influência da temperatura superficial do planeta até que essa atinja valores acima de $1500 \mathrm{~K}$, momento em que a relação entre a temperatura superficial e a emissão térmica se torna novamente importante, pois a superfície do planeta irradia no infravermelho próximo, através de janelas transparentes a esses comprimentos de onda.

A evolução do planeta está destinada a sofrer um brusco processo físico capaz de eva- 
porar todos os oceanos superficiais ao atingir o limiar de temperatura de $550 \mathrm{~K}$, porque qualquer ínfimo aumento da luminosidade solar ou deslocamento orbital, pode elevar a temperatura superficial do planeta a valores em torno de $1000 \mathrm{~K}$. Esse fenômeno é conhecido como runaway greehouse (vide figura 4.3) e deve ter ocorrido no início da história do planeta Vênus. Kasting estimou em 0,84UA a distância na qual esse processo deve ocorrer para o Sistema Solar, considerando a luminosidade solar atual. Porém, essa estimativa pode ser irreal, já que há incertezas quanto ao efeito das nuvens no comportamento do albedo planetário e das propriedades espectroscópicas do vapor de água a altas pressões.

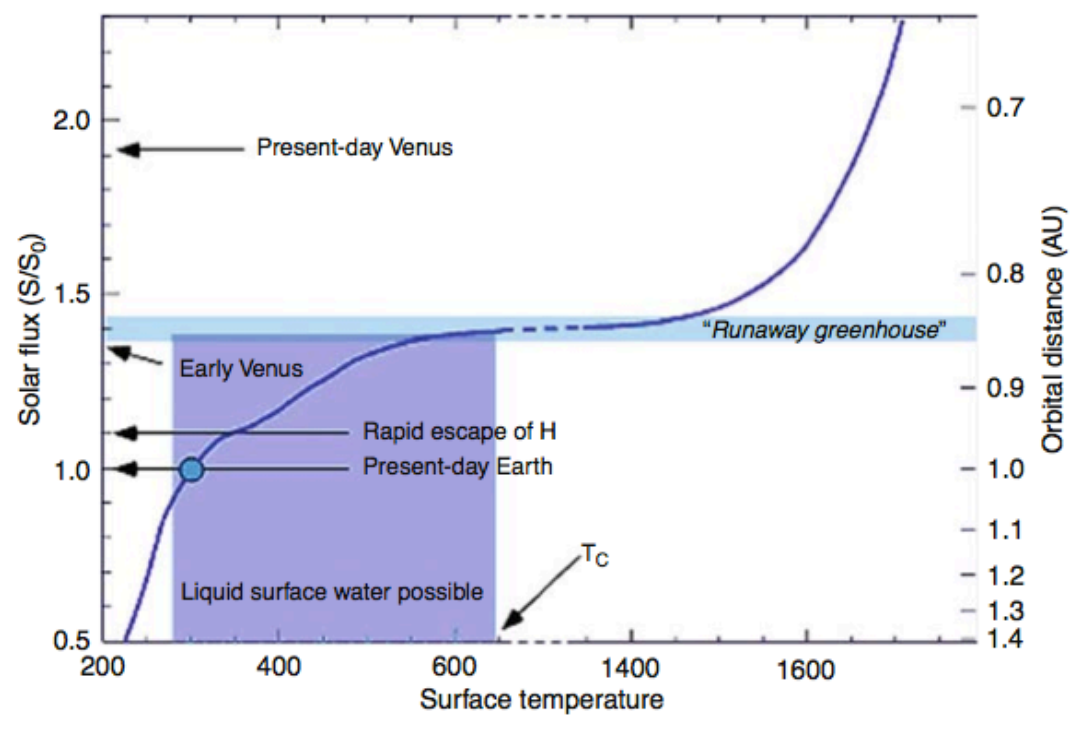

Figura 4.3: Efeito runaway greehouse para o Sistema Solar, considerando a luminosidade solar atual. Fonte: Ollivier et al. (2009), p. 231.

$\mathrm{Na}$ atmosfera terrestre atual, o vapor de água é o menor componente acima da tropopausa, região entre a troposfera e a estratosfera, onde a temperatura atinge um mínimo. Essa configuração da atmosfera terrestre cria uma região denominada cold trap, da qual o vapor da água não consegue ultrapassar, condensando à medida que sobe e, consequentemente, mantendo a perda de hidrogênio para o espaço a níveis ínfimos. 


\subsection{Limite Externo da Zona Habitável (Baseado na Observação do Sistema Solar)}

O limite externo da Zona Habitável pode ser entendido como a máxima distância orbital em relação à estrela hospedeira ao qual a temperatura superficial do planeta ou lua permaneça abaixo dos $273 \mathrm{~K}$, qualquer que seja o nível de $\mathrm{CO}_{2}$. Os modelos indicam que, a partir da distância orbital de 1,37 UA, nuvens de $\mathrm{CO}_{2}$ se formam na atmosfera e desencadeiam complexos processos que ainda não são totalmente conhecidos (Kasting, 1993). A presença de nuvens aumenta o albedo e tende a diminuir a temperatura superficial do planeta, já que este reflete uma maior quantidade de radiação solar. Porém, o espalhamento da emissão térmica proveniente da superfície do planeta, produz um efeito estufa prolongado, que é responsável pelo aumento da temperatura. De acordo com Forget e Pierrehumbert (1997), o efeito de aquecimento é predominante e as nuvens de $\mathrm{CO}_{2}$ permitem que as condições de habitabilidade se estendam a distâncias orbitais maiores que 1,37 UA, chegando a valores próximos de 2,40 UA para a luminosidade solar atual. É interessante notar que o planeta Marte está localizado dentro da chamada Zona Habitável, mas não oferece condições mínimas de habitabilidade. Em Marte o ciclo silicato-carbono, discutido detalhadamente em seções anteriores, não é operante, pois o fluxo de energia interna é muito fraco e incapaz de manter atividade vulcânica, além do planeta não possuir gravidade e campo magnético suficientemente intensos para manter uma atmosfera densa por longos períodos.

\subsection{Zona Habitável Contínua}

A luminosidade estelar aumenta à medida em que a estrela evolui, causando inevitavelmente o deslocamento da Zona Habitável em direção a distâncias orbitais maiores. É possivel definir a Zona Habitável Contínua como a região em torno da estrela hospedeira na qual um planeta ou lua, com características semelhantes à Terra, tenha tido ou possa oferecer condições mínimas de habitabilidade em um período de tempo maior ou menor que o atual (no caso do Sistema Solar aproximadamente 4,56 bilhões de anos). 


\subsection{Zona Habitável ao redor de Planetas Gigantes}

A definição tradicional de Zona Habitável não abrange a possibilidade da existência de ambientes extraterrestres capazes de abrigar vida, que estejam distantes da estrela hospedeira de seu sistema planetário. Satélites orbitando planetas gigantes fora dessa região privilegiada podem oferecer condições mínimas de habitabilidade. Essas condições estão diretamente relacionadas com uma massa mínima para que o satélite possa manter uma atmosfera densa, com o aquecimento devido ao efeito de maré, que fornece a energia necessária para que sua superfície tenha água líquida, um intenso campo magnético capaz de protegê-lo contra partículas energéticas, além de estabilidade orbital.

\subsection{Estrelas Favoráveis à Habitabilidade}

Espera-se encontrar condições de habitabilidade em planetas orbitando estrelas de classe F, G, K e M. Entretanto, o êxito na procura de planetas com características semelhantes à terrestre está intimamente correlacionado à massa da estrela hospedeira, pois estrelas mais massivas evoluem mais rapidamente e podem impossibilitar a evolução de uma biosfera. Modelos de evolução estelar sugerem que uma estrela de tipo espectral F, quente e 0,5 mais massiva que o Sol, deva evoluir completamente em aproximadamente 3 bilhões de anos (Kim et al., 2002; Yi et al., 2003), mostrando-se imprópria para o desenvolvimento das condições necessárias ao aparecimento de formas de vida mais simples que, acredita-se ter surgido na Terra, há aproximadamente 3,8 bilhões de anos. Esta constatação sugere a imposição de um limite superior para a massa estelar ao redor das quais planetas possivelmente possam ser habitados, pelo menos por micro-organismos extremófilos, considerando que eles tenham tido um processo de evolução semelhante ao da Terra; o limite superior para a massa dessas estrelas seria o intervalo entre 1,2-1,3 massas solares.

A presença de sistemas planetários ao redor de estrelas de menor massa, de tipo espectral K e M, conta com uma Zona Habitável de longa duração, porém reduzida devido ao fato de que elas apresentam baixa luminosidade. Uma Zona Habitável muito próxima da estrela hospedeira tem como consequência a existência de fortes efeitos gravitacionais (tidally locked) que tendem a frear rapidamente a rotação planetária (Dole, 1964). Este 
fenômeno faz com que um dos hemisférios do planeta fique sempre iluminado pela estrela central do sistema, enquanto o outro permanece completamente escuro e provavelmente gelado. Outro problema relacionado à curta distância orbital entre o planeta e sua estrela hospedeira é conhecido como Rotation Orbit Resonances: ocorre quando há órbitas excêntricas e efeitos de maré mais amenos, como ocorre por exemplo com Mercúrio, que está na ressonância $3: 2$ com o Sol, ou seja, o planeta executa três rotações enquanto completa duas voltas em torno da estrela.

Seguindo Dole (1964), Peale (1977) e Kasting et al. (1993), pode-se estimar o tempo necessário para que um planeta do tipo terrestre se torne tidally locked, através da equação:

$$
d_{T}=0,027\left(\frac{P_{0} t}{Q}\right)^{\frac{1}{6}} M_{s}^{\frac{1}{3}}
$$

As variáveis $P_{0}, Q, M_{S}$ e $t$ são, respectivamente, o período de rotação do planeta, a constante de dissipação de energia, a massa da estrela e o tempo. Kasting et al. (1993) estimaram em 4,5 bilhões de anos o tempo necessário para que uma planeta semelhante à Terra, com período de rotação igual a 13,5 horas, em órbita circular em torno de uma estrela de tipo M, se torne tidally locked.

Os eventos proporcionados pelo fenômeno de tidally locked são importantes ao se discutir conceitos relacionados à Zona Habitável, já que os efeitos climáticos ao qual o planeta fica submetido podem ser severos. Entretanto, estudos sugerem que planetas possuindo atmosferas densas são aptos a manter sua temperatura bem distribuída, através do transporte de calor entre um hemisfério e outro (Heath, 1996; Joshi et al., 1997).

As estrelas pouco massivas (K e M) possuem períodos prolongados de emissões de raios x e UV extremo, quando comparadas a estrelas do tipo Solar (107 anos) (Gudel et al., 1997; Ribas et al., 2005). Segundo os estudos conduzidos por Lammer et al. (2005) e Griessmeier et al. (2005), essa fase pode durar aproximadamente $10^{9}$ anos e ser acompanhada por ventos estelares mil vezes mais intensos que os ventos atuais do Sol. Planetas expostos a ventos estelares dessa magnitude podem perder todo o seu conteúdo atmosférico e até mesmo eventuais oceanos. Este cenário é possível, já que o campo magnético de planetas orbitando estrelas de baixa massa, responsável pela proteção contra a erosão atmosférica, deve ser menor que o terrestre, devido à baixa velocidade de rotação planetária. 


\subsection{Massa, Obliquidade, Tectonismo e Habitabilidade}

A massa de um planeta determina a evolução do fluxo de calor gerado internamente, além de prover uma atmosfera com gases e protegê-la contra o escape gravitacional. O valor mínimo capaz de garantir condições de habitabilidade por longos períodos ainda é incerto. Especula-se que a massa ideal para manter essas condições deva ser um pouco superior à massa do planeta Marte, que está localizado em uma distância orbital onde o escape gravitacional é menos eficiente. Williams et al. (1997) estimaram um limite de massa igual a 0,12 massas terrestres para que um corpo mantivesse uma atmosfera predominantemente composta por $N_{2}$ em um intervalo de tempo próximo a 4,5 bilhões de anos, argumentado que um objeto com a massa igual a de Marte $\left(\sim 0,1 M_{\oplus}\right)$ poderia perder seu conteúdo de ${ }^{14} N$ facilmente, mas não o mesmo envoltório de ${ }^{15} N$.

A reciclagem dos constituintes voláteis pela ação do tectonismo de placas é um dos principais mecanismos reguladores da composição da atmosfera terrestre. Através da entrega de gases, entre eles o $\mathrm{CO}_{2}$, que é o principal gás responsável pelo efeito estufa, a temperatura superficial do planeta se mantém acima dos $273 \mathrm{~K}$, oferecendo as condições necessárias à habitabilidade. O movimento das placas tectônicas também é importante para o desenvolvimento da vida complexa, pois além de garantir a presença de grandes continentes, foi capaz de isolá-los, provendo as condições necessárias para o surgimento de uma maior variedade de espécies. Esse movimento tectônico gera um campo magnético planetário intrínseco que é o responsável pela proteção da atmosfera frente a erosão causada pela sua interação com o vento solar, assim como pela deflexão dos raios cósmicos de alta energia (Ward e Brownlee, 2000). O mecanismo responsável pelo controle do tectonismo de placas ainda não é entendido completamente, porém alguns requerimentos são conhecidos: massa planetária suficiente para garantir a convecção do manto e grandes conteúdos de água no manto para lubrificar o deslocamento das placas (Regenauer-Lieb et al., 2001). A ausência de reservatórios de água é um dos possíveis fatores que justificam a ausência de movimentos tectônicos no planeta Vênus, mesmo possuindo uma massa com valor comparável a da Terra.

Planetas com ausência de satélites ou com satélites pouco massivos, podem experimentar mudanças periódicas em sua obliquidade, assim como é observado no planeta Marte. Esse cenário pode ser propício à geração de drásticas mudanças climáticas e até mesmo 
afetar o desenvolvimento da vida na superfície desses planetas. Esse efeito, entretanto, não deve ser intenso o suficiente para eliminar todos os organismos de uma biosfera (Laskar et al., 1993; Kasting e Catling, 2003).

\subsection{Zona Habitável e Zona Extremófila neste Trabalho}

A Zona Habitável pode ser compreendida de várias maneiras. Nesse trabalho, ela será definida como a região ao redor da estrela hospedeira onde a temperatura superficial média de um planeta ou lua se encontre na faixa de $273-323 \mathrm{~K}$, quando submetidos a pressões parciais de $\mathrm{CO}_{2}$ variando entre $10^{-5}-10$ bars. Essa definição visa abranger objetos com clima análogo ao terrestre, que possam prover condições físico-químicas essenciais ao desenvolvimento de organismos mesófilos e termófilos moderados.

Entretanto, micro-organismos podem sobreviver em ambientes onde prevalecem condições físico-químicas extremas, inclusive na superfície de planetas e luas. Como o objetivo principal dessa pesquisa é avaliar a possibilidade de organismos extremófilos habitarem a superfície desses corpos, provavelmente comuns a diversos sistemas planetários, haverá a imposição de aspectos distintos da visão antrópica, ao se definir a região onde esses seres vivos podem ser encontrados, ou seja, ampliar-se-á o conceito de Zona Habitável. Essa ampliação, denominada Zona Extremófila, apresentará seus limites interno e externo, baseados também em valores de pressão e temperatura: a pressão parcial de $\mathrm{CO}_{2}$ na superfície do objeto de estudo poderá variar na faixa entre $10^{-5}-10$ bars, enquanto a temperatura superficial média, entre $190-370 \mathrm{~K}$.

O limite externo da Zona Extremófila está firmado no argumento de que mesmo ambientes onde a temperatura seja suficientemente baixa, ainda podem existir oceanos subsuperficiais conectados à superfície ou mesmo ambientes superficiais extremos (interior de rochas, filmes finos, lagos, etc ), capazes de abrigar micro-organismos; já o limite interno da Zona Extremófila, por sua vez, está correlacionado com a presença dominante de vapor de água na atmosfera. Ambos os extremos de temperatura serão considerados de forma conjunta com a variação da pressão superficial de $C O_{2}$ em um intervalo de $10^{-5}-10$ bars. 
Capítulo 5

\section{Atmosferas Planetárias}

A origem das atmosferas planetárias está associada aos processos de captura de gás diretamente do disco protoplanetário (para planetas massivos) ou sua agregação durante o período de acresção dos planetesimais (para planetas de baixa massa). O primeiro mecanismo é o responsável pelo conteúdo atmosférico de planetas gigantes como Júpiter e Saturno, enquanto que o segundo é associado à composição da atmosfera de planetas rochosos como Vênus, Terra e Marte. A fonte desse envoltório gasoso depende da localização do planeta no disco protoplanetário durante o período de sua formação, já que há um gradiente de composição nesse disco responsável pela segregação entre planetas rochosos e gasosos como visto no capítulo 1. Essas atmosferas sofrem alterações durante a evolução do planeta ou lua, devido a processos como: escape atmosférico, incorporação de gases pelos oceanos, impactos de meteoros e cometas, tectonismo, bombardeamento por partículas carregadas, interação com a biosfera, etc.

Qual a importância do estudo das atmosferas planetárias na busca de vida extraterrestre? O estudo da composição atmosférica e sua interação com a biosfera, assim como de sua estrutura vertical, é fundamental para a compreensão das condições que levam um objeto, planeta ou lua, a se apresentar como candidato potencial a abrigar vida, mesmo que em sua forma mais simples. A vida complexa não encontra condições ótimas para se desenvolver em ambientes com excesso ou deficiência atmosférica, mas extremófilos talvez possam ser encontrados nas superfícies de Marte ou até mesmo de Titã. A condição mais fundamental para a existência da vida é a presença de solventes que possam catalizar reações químicas, dos quais o mais importante é a água; a interação da atmosfera com a superfície do planeta pode simplesmente impossibilitar a presença de água no estado 
líquido. Sabe-se também que a atmosfera é um protetor contra a degradação de materiais biológicos causada pelo contato direto com a radiação solar, além de participar ativamente dos ciclos geodinâmicos, como o ciclo silicato-carbono, essenciais para a manutenção das condições mínimas de habitabilidade na superfície do planeta. Assim, atmosfera e vida estão intimamente ligados e a identificação de corpos capazes de manter esse envoltório gasoso por longos períodos é um dos alvos principais das pesquisas recentes.

\subsection{Composição das Atmosferas Planetárias}

Uma atmosfera planetária pode ser definida como um envelope gasoso do corpo celeste. O interesse principal na compreensão dessa mescla de gases é entender sua contribuição para o desenvolvimento da vida em planetas com características semelhantes a terrestre. $\mathrm{O}$ termo atmosfera também pode ser empregado ao estudo das propriedades de outros corpos gasosos, planetas gigantes e estrelas, assim como objetos menores, os satélites ou cometas. O contexto deste estudo é baseado nas propriedades físico-químicas observadas no Sistema Solar, já que é conhecido de forma satisfatória o seu processo evolutivo.

A atmosfera terrestre evoluiu a partir de interações com a biosfera e parece ser a única capaz de sustentar vida complexa no Sistema Solar. A maioria dos planetas e satélites do Sistema Solar apresenta algum conteúdo atmosférico, mesmo que insuficiente para garantir as condições necessárias para a habitabilidade em suas superfícies. Dentro desse contexto, os planetas gigantes formam um conjuto de objetos de grande interesse na busca de vida extraterrestre, pois configurações adequadas podem garantir condições mínimas para que organismos sobrevivam na superfície de suas luas (vide capítulos 4 e 6).

A tabela 5.1 apresenta algumas das principais propriedades planetárias atmosféricas referentes a valores superficiais conhecidos ou a pressões mínimas de 1 bar. 
Tabela 5.1 - Propriedades atmosféricas planetárias.

\begin{tabular}{cccc}
\hline \hline Corpo Planetário & Pressão (bars) & Escala de Altura $(\mathrm{km})$ & Lapse Rate $^{a}(\mathrm{~K} / \mathrm{km})$ \\
\hline \hline Júpiter & 1,00 & 27,00 & 1,80 \\
\hline \hline Saturno & 1,00 & 59,50 & 0,70 \\
\hline \hline Urano & 1,00 & 19,10 & 0,80 \\
\hline \hline Netuno & 1,00 & 27,70 & 1,00 \\
\hline \hline Titã & 1,50 & 21,50 & 1,30 \\
\hline \hline Tritão & $1,60.10^{-5}$ & 13,40 & 0,74 \\
\hline \hline Plutão & $\sim 10^{-5}$ & $\sim 22,00$ & $\sim 0,60$ \\
\hline \hline Io & $\sim 10^{-8}$ & 7,90 & 3,10 \\
\hline \hline Marte & $(6,90-9,00) .10^{-3}$ & 11,10 & 4,50 \\
\hline \hline Vênus & 90,00 & 15,90 & 10,50 \\
\hline \hline Terra & 1,00 & 8,40 & 9,80 \\
\hline \hline
\end{tabular}

${ }^{a}$ A lapse rate, representada matematicamente por $\Gamma(Z)=-\frac{d T}{d Z}$, descreve a taxa de decréscimo da temperatura em função da altura.

O estudo das características de planetas e seus satélites pode ser realizado através da análise do espectro eletromagnético da luz refletida por eles. Esses espectros apresentam linhas de absorção que são assinaturas da constituição gasosa de suas atmosferas, o que facilita a identificação de sua composição, além de indicar indícios de atividade biológica em suas superfícies. A figura 5.1 mostra uma comparação entre o espectro de absorção dos planetas Marte, Terra e Vênus. 


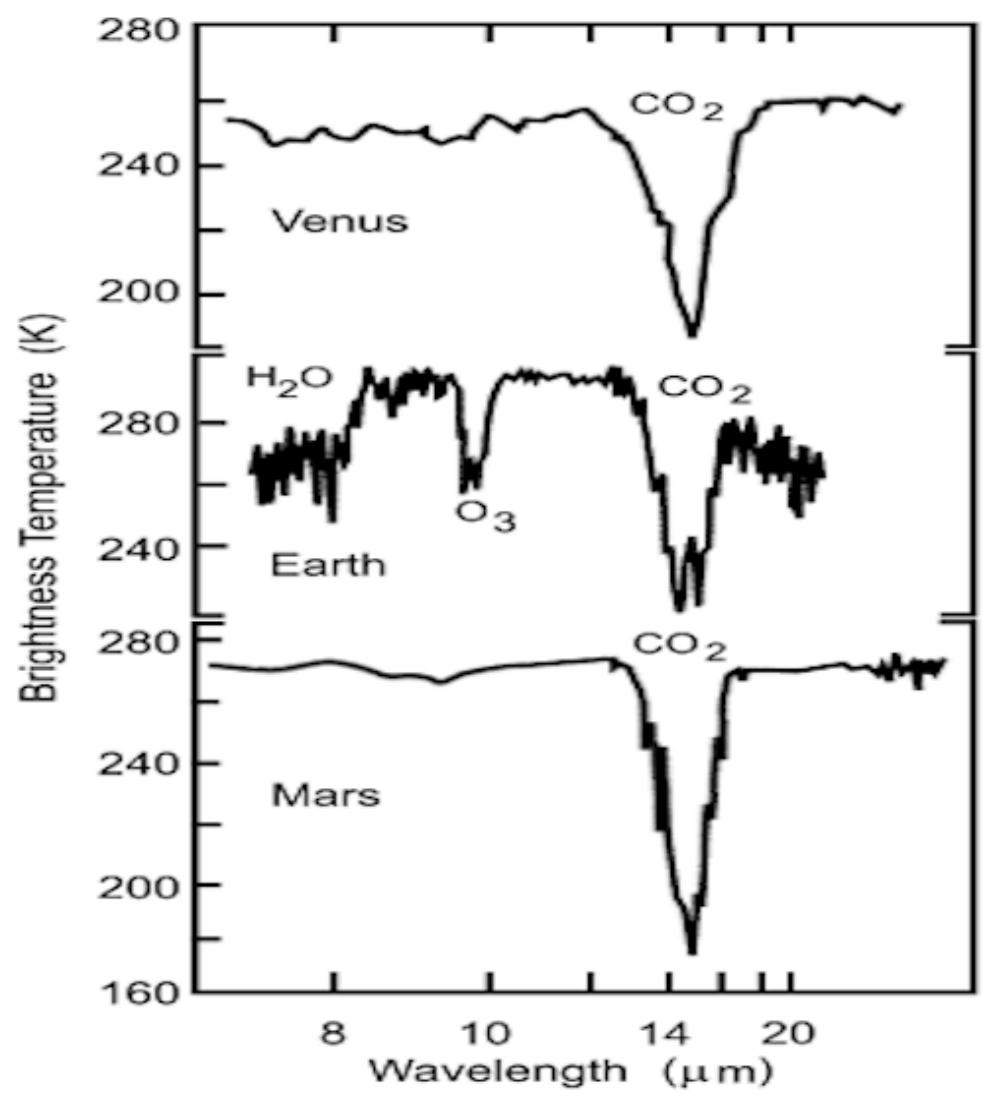

Figura 5.1: Espectro no infravermelho médio dos planetas terrestres do Sistema Solar. Fonte: (Woolf e Angel, 1998).

Considerando que o processo de formação de todos os sistemas planetários segue os mesmos mecanismos físicos é bem provável que as atmosferas de planetas extrasolares possuam constituição semelhante a dos planetas do Sistema Solar. Por exemplo, o espectro infravermelho da atmosfera dos planetas gigantes do Sistema Solar apresenta caracterísitcas espectrais de espécies gasosas como o $\mathrm{CH}_{4}, \mathrm{NH}_{3}, \mathrm{H}_{2} \mathrm{O}$ e $\mathrm{H}_{2}$, assim como a análise desse espectro para planetas rochosos mostra uma forte absorção devido ao $\mathrm{CO}_{2}$. A composição molecular da baixa atmosfera terrestre é dominada predominantemente pelo $N_{2}(78,08 \%)$ e $O_{2}(20,95 \%)$, assim como por pequenas frações de gases responsáveis pelo efeito estufa, como o $\mathrm{CO}_{2}, \mathrm{CH}_{4}$ e $\mathrm{N}_{2} \mathrm{O}$, dos quais o dióxido de carbono e o metano, por possuírem uma seção de choque de absorção maior, destacam-se como os principais gases de aquecimento planetário (o poder de absorção é igual a densidade numérica vezes a seção de choque de absorção).

A tabela 5.2 mostra os principais gases que constituem a atmosfera terrestre, onde 
são destacados os papéis do vapor de água e do ozônio como gases de efeito estufa, além do dióxido de carbono. Como mencionado no capítulo 4, o excesso de vapor de água na atmosfera pode levar o planeta a uma condição não favorável ao desenvolvimento da vida, caso o processo de runaway greenhouse aconteça.

Tabela 5.2 - Principais gases constituintes da atmosfera terrestre.

\begin{tabular}{ccc}
\hline \hline Espécies Gasosas & Peso Molecular & Concentração Fracional por Volume \\
\hline \hline Nitrogênio & 28,01 & $78,08 \%$ \\
\hline \hline Oxigênio & 32,00 & $20,95 \%$ \\
\hline \hline Argônio & 39,95 & $0,93 \%$ \\
\hline \hline Vapor de Água & 18,02 & $0-5 \%$ \\
\hline \hline Dióxido de Carbono & 44,01 & $380 \mathrm{ppm}$ \\
\hline \hline Neônio & 20,18 & $18 \mathrm{ppm}$ \\
\hline \hline Hélio & 4,00 & $5 \mathrm{ppm}$ \\
\hline \hline Metano & 16,04 & $1,75 \mathrm{ppm}$ \\
\hline \hline Criptônio & 83,80 & $1 \mathrm{ppm}$ \\
\hline \hline Hidrogênio & 2,02 & $0,5 \mathrm{ppm}$ \\
\hline \hline Óxido Nitroso & 56,03 & $0,3 \mathrm{ppm}$ \\
\hline \hline Ozônio & 48,00 & $0-0,1 \mathrm{ppm}$ \\
\hline \hline
\end{tabular}

A composição atmosférica de um planeta gasoso é muito distinta da terrestre. Considerando Júpiter como exemplo, nota-se que há um acentuado conteúdo de hidrogênio, provavelmente relacionado com a captura e retenção do material proveniente da nebulosa solar. Logo, é intuitivo considerar que a atmosfera desse planeta não tenha passado por processos consideráveis de evolução, ou seja, é primitiva. Em termos de abundância de elementos químicos, Júpiter possui uma atmosfera basicamente semelhante à Solar; vale salientar que todos os planetas gigantes do Sistema Solar possuem atmosferas semelhantes a do Sol, apresentando um leve desvio relativo à quantidade de carbono que aumenta com a distância da estrela (Marley et al., 1997). Júpiter apresenta, então, uma atmosfera mista composta predominantemente pelos gases hidrogênio e hélio. Esses gases são espécies relativamente inertes, isto é, não são bons absorvedores ou emissores e assim não apresentam características intensas no espectro planetário, porém o gás metano, apesar de sua pouca abundância, é um ótimo absorvedor e domina o espectro visível do planeta. Na tabela 5.3 é mostrada a composição atmosférica básica dos planetas gigantes do Sistema Solar. 
Tabela 5.3 - Composição atmosférica dos planetas gigantes do Sistema Solar.

\begin{tabular}{cccc}
\hline \hline Planeta & $\mathrm{H}_{2}(\%)$ & $\mathrm{He}(\%)$ & $\mathrm{CH}_{4}(\%)$ \\
\hline \hline Júpiter & $86,2 \pm 2,6$ & $13,6 \pm 2,6$ & $0,21 \pm 0,04$ \\
\hline \hline Saturno & $96,3 \pm 2,4$ & $3,25 \pm 2,4$ & $0,45 \pm 2,4$ \\
\hline \hline Urano & $\sim 82,5 \pm 3,3$ & $15,2 \pm 3,3$ & $\sim 2,3$ \\
\hline \hline Netuno & $\sim 80 \pm 3,2$ & $19,0 \pm 3,2$ & $\sim 1-2$ \\
\hline \hline
\end{tabular}

Pode-se afirmar que o estudo da composição atmosférica planetária é uma ferramenta importante na análise das possibilidades reais de se encontrar planetas ou satélites habitáveis. A comparação entre o espectro terrestre com os dos possíveis mundos similares pode informar se esses são ou não propícios a abrigar formas de vida, principalmente pela observação de características de absorção de vapor de água, metano e oxigênio.

\subsection{A Estrutura Vertical da Atmosfera}

A interação da radiação estelar com o planeta está fortemente correlacionada com a composição de sua atmosfera, cujo perfil vertical desempenha um papel importante em sua sintonia com a superfície. Na Terra, a radiação solar é absorvida em diferentes altitudes, dependendo do comprimento de onda da luz e dos constituintes atmosféricos. A absorção dessa radiação e o consequente aquecimento cria um perfil vertical de temperatura a latitudes médias, que pode ser dividido em quatro camadas: troposfera, estratosfera, mesosfera e termosfera. A parte superior de cada uma dessas camadas são denominadas tropopausa, estratopausa, mesopausa e termopausa respectivamente.

As condições físicas são bem diversificadas em cada porção que compõe a atmosfera planetária e se ela for aproximada por um envoltório gasoso em equilíbrio hidrostático existe a possibilidade de se derivar uma relação entre a pressão dos gases que a compõe e a altitude, através das leis da hidrostática e dos gases ideais:

$$
\begin{gathered}
\frac{d P}{d Z}=-\rho g \\
P=n k T,
\end{gathered}
$$

onde $Z$ é altitude acima do solo, $P$ e $\rho$, a pressão e a densidade atmosféricas, $g$ a aceleração 
da gravidade, $n$ a densidade numérica, $k$ a constante de Boltzmann e $T$ a temperatura. As densidades de massa e numérica são relacionadas pela expressão $\rho=m \times n$, com a variável $m$ representando a massa molecular média. A combinação dessas equações leva a uma relação que fornece uma explicação plausível para a queda da pressão atmosférica com o aumento da altitude:

$$
\frac{d P}{P}=-\frac{d Z}{H}
$$

onde a variável $H=\frac{k T}{m g}$ representa a "escala de altura" atmosférica. Em uma atmosfera isotérmica em que $H$ quase não sofre alterações, pois a gravidade e massa são praticamente invariáveis, a equação 5.3 quando integrada pode ser escrita como:

$$
P(Z)=P\left(Z_{0}\right) \exp \left(-\frac{Z-Z_{0}}{H}\right)
$$

A troposfera, localizada na baixa atmosfera, é caracterizada por um decréscimo da temperatura em função da altitude, com uma lapse rate típica de $6,5 \mathrm{~K} \mathrm{~km}^{-1}$. Próximo a superfície do planeta o valor médio dessa temperatura é $288 K$, mas nas proximidades da tropopausa atinge valores próximos a $220 \mathrm{~K}$. O comportamento da temperatura nessa camada é consequência do balanço radioativo e do transporte convectivo de energia da superfície em direção à atmosfera. A troposfera terrestre, por constituir um envelope que agrega a maior quantidade de massa atmosférica e ser a região onde os processos climáticos acontecem, é considerada a camada mais importante e sua interação com a biosfera torna-se essencial para garantir as condições mínimas de habitabilidade.

A estratosfera é caracterizada por uma camada isotérmica que se estende desde a tropopausa até aproximadamente uma altitude de $20 \mathrm{~km}$, acima da qual há um aumento de temperatura que persiste até a base da estratopausa, onde a temperatura atinge o valor aproximado de $270 \mathrm{~K}$; nessa camada ocorre uma injeção de energia devido a interação entre a radiação solar e as moléculas de ozônio, sendo essa interação a responsável pela proteção dos organismos vivos sensíveis à radiação na faixa do UV.

De forma similar à troposfera, a mesosfera tem como característica o decréscimo da temperatura com a altitude, processo que tem início em altitudes próximas a $50 \mathrm{~km}$ e termina em $85 \mathrm{~km}$, na mesopausa. A altitudes superiores $85 \mathrm{~km}$, encontra-se a termosfera, que exibe temperaturas variando entre 500 e $2000 K$, dependendo da atividade solar. A 
região acima da termosfera, compreendida entre 500 e 1000 km, é conhecida como exosfera e tem como característica uma densidade baixa o suficiente para permitir o escape de gases em direção ao espaço. Em geral, a temperatura decresce com a altura $(\Gamma>0)$ na troposfera e aumenta $(\Gamma<0)$ na estratosfera. A camada onde ocorre a transição entre a menor e a maior temperatura é chamada de camada de inversão.

A figura 5.2 mostra o perfil de temperatura da atmosfera terrestre.

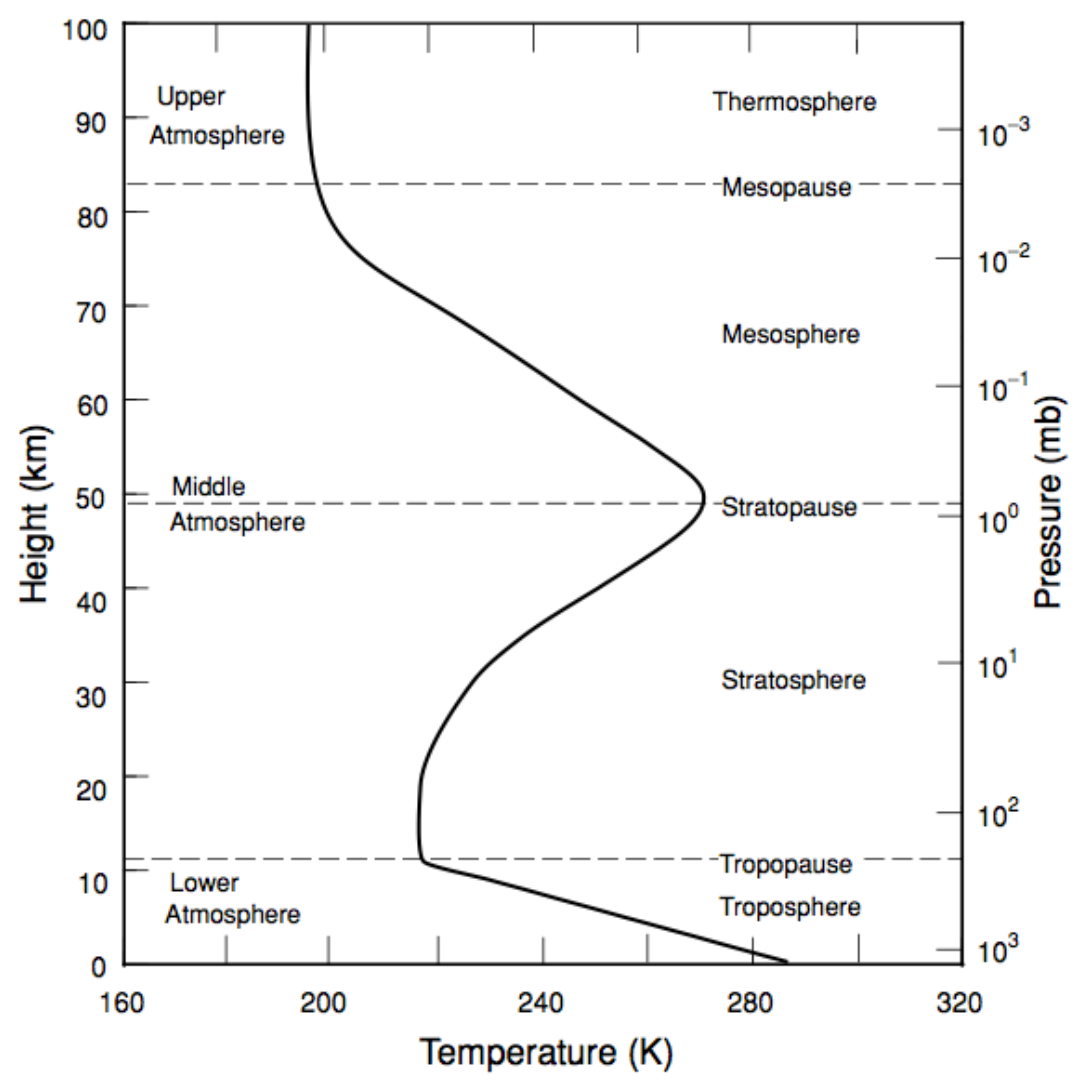

Figura 5.2: Perfil de temperatura da atmosfera terrestre. Fonte: Liou (2002), p. 66.

A pressão atmosférica terrestre ao nível do mar decresce aproximadamente de um fator $e(e=2,7)$, quando a altitude aumenta por uma escala de altura, isto é, aproximadamente $8 \mathrm{~km}$. Essa escala é uma característica intrínseca do planeta e atinge valores distintos para outros, com propriedades distintas da Terra. Como a escala de altura é inversamente proporcional à gravidade e à massa molecular média, um planeta massivo concentra seu conteúdo atmosférico nas proximidades de sua superfície. Uma análise do exposto acima revela que a escala de altura dos planetas gigantes é comparável a de planetas rochosos, mas deve ser afetada fortemente pela variação da massa molecular média e pelo processo 
de transferência radiativa, que é uma função da opacidade atmosférica.

O conhecimento do modo como os gases se distribuem com a altitude pode ajudar na estimativa da massa total gasosa que constitui a atmosfera planetária. O valor da pressão na base da atmosfera é igual ao peso do material sobrejacente por unidade de área; assim, a quantidade de atmosfera existente acima de uma unidade de área de superfície de $1 \mathrm{~m}^{2}$ é obtida dividindo a pressão pela aceleração da gravidade:

$$
m_{c o l}=\frac{P\left(Z_{0}\right)}{g},
$$

em que $m_{c o l}$ é a massa da coluna sobrejacente. A massa total atmosférica de um planeta pode ser medida pelo produto da massa dessa coluna pela área total da superfície do planeta:

$$
M_{a t m}=\frac{4 \pi R_{p}^{2} P\left(Z_{0}\right)}{g},
$$

onde $R_{p}$ é o raio do planeta. A massa atmosférica terrestre é estimada em aproximadamente $5,2.10^{18} \mathrm{~kg}$. A partir do conhecimento da massa atmosférica e da taxa de escape $\left(\phi_{\text {esc }}\right)$ de um objeto, é possível deduzir de forma aproximada o tempo no qual sua envoltura gasosa está apta a garantir as condições de habitabilidade:

$$
\tau=\frac{\frac{M_{a t m}}{m}}{\phi_{e s c} 4 \pi R_{p}^{2}}=\frac{P\left(Z_{0}\right)}{\phi_{e s c} g m}
$$

William et al. (1997) argumentam que a perda do $O_{2}$ não é necessariamente determinante para a habitabilidade planetária, pois esse gás é constantemente reposto pelo processo de fotossíntese e pelos reservatórios aquáticos, mas a diminuição do conteúdo de $N_{2}$ pode ser fatal ao desenvolvimento da vida, já que o nitrogênio é necessário, por exemplo, para metabolismo dos organismos.

\subsection{Escape Atmosférico}

A perda atmosférica é um fator limitante à manutenção das condições de habitabilidade de um planeta. Há duas situações que podem fazer com que planetas tenham seu conteúdo atmosférico comprometido: o escape de elementos leves ao longo do tempo e a ejeção, 
até mesmo de elementos pesados, devido à proximidade em relação a estrela central. O escape atmosférico envolve três etapas principais: em um primeiro momento, os gases são transportados da baixa atmosfera para a alta atmosfera, onde a fuga pode ocorrer; a etapa seguinte é a conversão do gás atmosférico molecular em formas iônicas ou atômicas; finalmente, a terceira etapa é o escape propriamente dito, que pode ocorrer através de processos como o escape hidrostático térmico, o escape hidrodinâmico térmico e o escape não térmico. O processo que comanda o escape atmosférico vai depender das características intrínsecas do planeta e de seu sistema planetário, como visto no capítulo 4.

\subsubsection{Escape Atmosférico Hidrostático Térmico}

O escape hidrostático térmico ocorre quando um átomo ou molécula escapa da atmosfera planetária por possuir sua velocidade térmica maior do que a velocidade de escape do planeta:

$$
\left[\frac{2 k T_{x}}{m}\right]^{\frac{1}{2}}>\frac{1}{6}\left[\frac{2 G M_{p}}{R_{p}}\right]^{\frac{1}{2}}
$$

Na equação acima, $T_{x}$ é a temperatura da exosfera, $m$ a massa atômica ou molecular, $k$ a constante de Boltzmann, $G$ a constante gravitacional, $R_{p}$ e $M_{p}$, o raio e massa do planeta, respectivamente.

Uma forma mais apurada de descrever o processo de escape térmico é através do clássico escape de Jeans, que considera esse mecanismo como uma distribuição Maxwelliana padrão. O escape de Jeans pode ser descrito matematicamente como:

$$
\phi_{\text {Jeans }}=\frac{n_{c} v_{s}}{\sqrt{2 \pi}}\left(1+\lambda_{c}\right) e^{-\lambda_{c}}
$$

onde $v_{s}=\left(\frac{k T_{x}}{m}\right)$ é a velocidade média das partículas, $n_{c}=\frac{1}{\sigma H_{x}}$ a densidade numérica das partículas na exosfera, $H_{x}=\frac{k T_{x}}{m g_{x}}$ a escala de altura na base da exosfera, $\lambda_{c}=\frac{G M_{p} m}{k T_{x} r_{c}} \mathrm{o}$ parâmetro de escape e $r_{c}=R_{p}+r_{x}$ a altura da exobase a partir do centro do planeta. As variáveis com subíndice $x$ referem-se a valores típicos da exosfera; $\sigma$ é a seção de choque colisional de escape das partículas. Caso o mecanismo de escape de Jeans seja predominante, existe a possibilidade de se estimar o tempo para que a totalidade do processo ocorra partindo da equação 5.7: 


$$
\tau_{\text {hidrost }}=\frac{\frac{M_{a t m}}{m}}{\phi_{\text {Jeans }} 4 \pi R_{p}^{2}}=\frac{P\left(Z_{0}\right)}{\phi_{\text {Jeans }} g m}
$$

\subsubsection{Escape Atmosférico Hidrodinâmico Térmico}

O escape hidrodinâmico térmico ocorre quando a velocidade de escape é tão alta que a atmosfera se comporta como um fluido, que se expande radialmente em direção ao espaço. Esse processo está associado a episódios de perda atmosférica em fases iniciais da formação dos sistemas planetários. Para que ocorra o escape hidrodinâmico há a necessidade de que uma grande quantidade de radiação UV $(E U V)$ estelar interaja com a alta atmosfera e dirija o mecanismo de aquecimento dessas regiões. Ele ocorre quando a atmosfera planetária é aquecida violentamente ao ponto da velocidade das partículas ser tão alta que a gravidade não consegue evitar sua ejeção. Durante o escape hidrodinâmico, elementos pesados como o $C, N$ e $O$, podem ser carregados durante o fluxo de escoamento de elementos mais leves como o $H$, e dependendo da composição atmosférica, os primeiros podem ser o principal constituinte do fluxo ejetado.

Uma estimativa para o escape hidrodinâmico pode ser obtida através da energia limite de escape. A energia potencial gravitacional de um planeta pode ser calculada por:

$$
E_{P}=-\frac{G M_{p} M_{a t m}}{\beta R_{p}},
$$

onde $\beta R_{p}$ representa a extensão radial da exosfera. Ao ignorar a estrutura radial atmosférica e tomar a equação $P_{U V}=\pi R_{p}^{2} F_{E U V}\left(J . s^{-1}\right)$ como sendo a potência do fluxo de radiação UV extremo incidente no planeta, pode-se estimar o tempo de resistência da atmosfera frente ao escape hidrodinâmico (Lecavelier Des Etangs, 2007):

$$
\tau_{h i d r} \sim\left[\frac{G}{\pi}\right]\left(\frac{M_{p}}{R_{p}^{3}}\right) \frac{M_{a t m}}{\beta \eta<F_{E U V}>},
$$

sendo $\left\langle F_{E U V}>\right.$ o fluxo de radiação médio e $\eta$ a fração dessa radiação que eleva a temperatura da atmosfera e dirige o processo de escape. Essa estimativa tem limitações associadas ao desconhecimento dos mecanismos que controlam a ocorrência e a evolução do fluxo de radiação estelar em sistemas extrasolares, que para o Sol segue a lei $\left(\frac{4,6 \text { G anos }}{t}\right)^{5 / 6}$ (Zahnle e Walker, 1982), assim como das propriedades intrínsecas dos planetas (massa, atmosfera, densidade, conteúdo de água, etc). 


\subsubsection{Mecanismos não Térmicos de Escape Atmosférico}

Os mecanismos não térmicos de escape se referem a processos colisionais entre espécies de partículas carregadas que produzem átomos suficientemente energéticos para escapar da atmosfera planetária rumo ao espaço. Esse processo habilita o escape de átomos pesados como o $N, C$ e $O$, cujas velocidades térmicas são muito baixas; aliás, alguns eventos podem ser abrangidos por esse termo: processos de troca de cargas, conversão de energia fotoquímica em energia cinética, escape iônico, sputtering e pickup iônico (Shizgal e Arkos, 1996).

A troca de cargas envolve a colisão entre um íon e um átomo, onde o excesso de energia do íon é transferido para o átomo. A radiação solar EUV gera íons via fotodissociação de átomos e essas partículas ganham energia cinética em sua interação com a magnetosfera planetária. A troca de carga entre o íon $H^{+}$e o átomo $H$ é o mecanismo principal pelo qual a atmosfera perde hidrogênio, superando o escape de Jeans; reações de troca de carga também podem acontecer com outros átomos térmicos, como o oxigênio:

$$
\begin{aligned}
& H+H^{+*} \rightarrow H^{+}+H^{*} \text { troca de carg as } \\
& O+H^{+*} \rightarrow O^{+}+H^{*} \text { troca de carg as }
\end{aligned}
$$

onde ${ }^{*}$ significa excesso de energia cinética.

A conversão de energia fotoquímica em energia cinética é também possível, pois elétrons oriundos da fotodissociação ou átomos criados a partir da fotodissociação molecular podem carregar o excesso de energia produzido. Alternativamente, elétrons e íons gerados através desses processos podem se recombinar ou sofrer impactos, produzindo energia da ordem de poucos $e V$ (elétronvolts). Já a recombinação dissociativa ocorre quando existe a combinação de um íon molecular com um elétron livre, gerando uma população de átomos energéticos; hoje, esse processo é um importante mecanismo de erosão atmosférica em Marte, mas não na Terra ou em Vênus (Lammer et al., 2008). Abaixo são mostradas algumas dessas interações:

$$
\mathrm{O}_{2}^{+}+e \rightarrow \mathrm{O}^{*}+\mathrm{O}^{*} \text { recomb. dissociativa }
$$




$$
\begin{gathered}
O H^{+}+e \rightarrow O+H^{*} \text { recomb. dissociativa } \\
N_{2}+e^{*} \rightarrow N^{*}+N^{*} \text { dissoc. por impacto } \\
O_{2}+h \nu \rightarrow O^{*}+O^{*} \text { fotodissoc. }
\end{gathered}
$$

O escape iônico é o processo pelo qual um fluxo de íons escapa através das linhas de campo magnético que são abertas na magnetocauda planetária, em consequência da interação da magnetosfera com o vento solar magnetizado. Na Terra, o escape iônico é um processo importante nas regiões polares.

Impactos de átomos ou íons em superfícies geram um fenômeno de ejeção de átomos chamado de sputtering. Esses impactos ainda podem ocasionar uma aceleração que conduz o escape atmosférico por meio de uma cascata de colisões que, por sua vez, cria partículas energéticas que escapam da atmosfera (fenômeno conhecido por knockon). Porém, essa perda de conteúdo atmosférico pode ser eliminada pela presença de um campo magnético efetivo.

O mecanismo de pickup iônico ocorre devido à interação do vento estelar com ionosfera planetária. As ondas de plasma eletromagnético estelar se estendem até as órbitas dos planetas por meio do vento estelar (campo magnético interplanetário), que carrega os íons da atmosfera planetária, acelerando-os para regiões afastadas. Campos magnéticos semelhantes ao terrestre protegem a atmosfera desse mecanismo de escape, mas sua ausência, facilita a penetração do vento estelar até a exosfera onde ocorre a ionização de espécies neutras, levando-as ao espaço exterior.

\subsection{Evolução da Atmosfera de Planetas Rochosos}

A atmosfera terrestre primitiva foi dominada pelos gases $\mathrm{CO}_{2}$ e $\mathrm{N}_{2}$, entretanto mecanismos de entrega de conteúdos como vapor de água, $\mathrm{NH}_{3}, \mathrm{CH}_{4}$ e $\mathrm{H}_{2}$, também contribuíram para a complexidade desse envoltório gasoso. O elevado conteúdo inicial de dióxido de carbono de aproximadamente 10 bars (Walker, 1985), provavelmente foi dissolvido nos 
oceanos e incorporado na formação de carbonatos (Urey, 1952; Zahnle et al., 2007), permitindo que sua concentração atual, dentro do total de gases da atmosfera terrestre, seja menor que $1 \%$. Análises recentes de rochas sedimentares precambrianas apontam para o surgimento de uma atmosfera de $\mathrm{O}_{2}$ há aproximadamente 2, 4 bilhões de anos (Farquhar et al., 2000), sendo produzida em larga escala por organismos vivos através do processo de fotossíntese; as cianobactérias foram provavelmente os primeiros organismos a realizarem esse processo e sintetizaram o oxigênio há 300 milhões de anos antes da atmosfera tornar-se oxigenada. Apesar da origem desconhecida do $N_{2}$ (especula-se que esse gás foi incorporado via impactos), sua presença é de grande importância na procura de planetas habitáveis, já que é essencial ao metabolismo dos organismos. Ainda que pouco conhecido e controverso, um cenário para a possível evolução da atmosfera terrestre pode ser representado pela figura $5.3^{13}$.

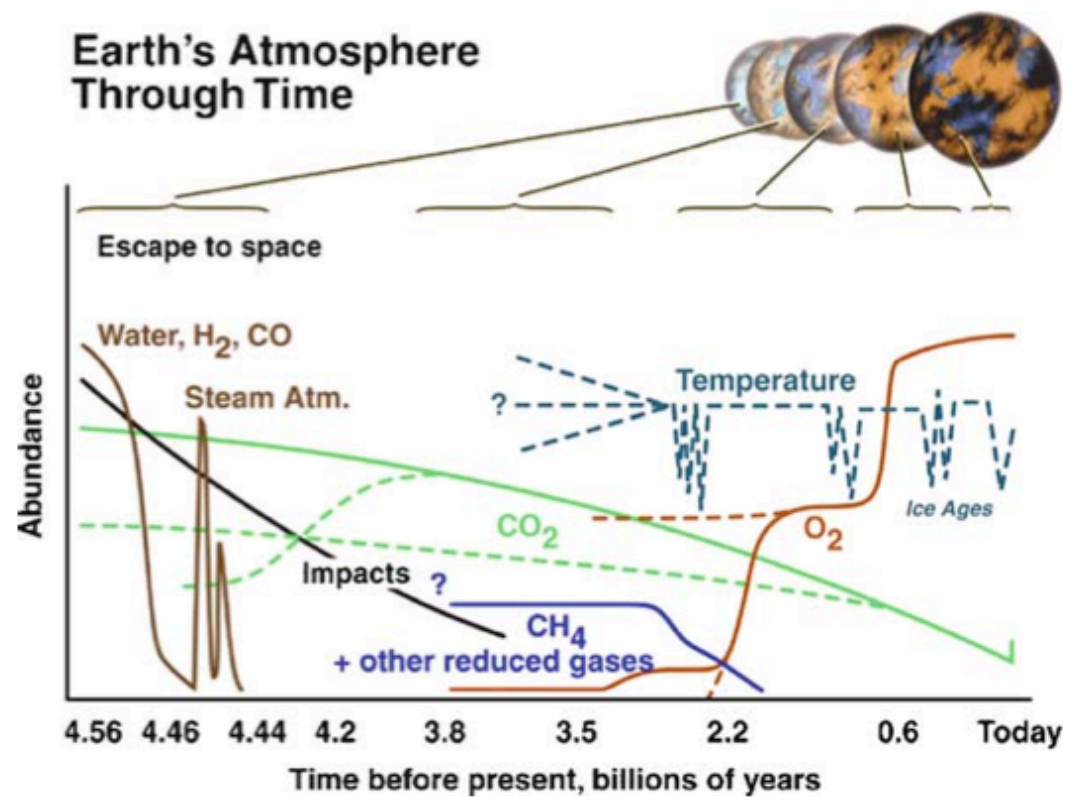

Figura 5.3: História da composição química da atmosfera terrestre. Observa-se o aumento recente nos níveis de $\mathrm{O}_{2}$, provavelmente devido ao aparecimento dos organismos fotossintetizantes. Fonte: NASA Science News, 2002.

Apesar da semelhança (tamanho e massa) com a Terra, Vênus possui uma atmosfera distinta da terrestre. Entretanto, acredita-se que em seu passado, Vênus tenha tido atmosfera e oceanos superficiais semelhantes aos terrestres. Porém, devido ao efeito ru-

\footnotetext{
${ }^{13}$ Conteúdo em: http://science.nasa.gov/science-news/science-at-nasa/2002/. Acesso em: 21/07/2012.
} 
naway greehouse e ao escape hidrodinâmico de hidrogênio (proximidade do Sol e ausência de campo magnético) (Kasting e Pollack, 1983), Vênus apresenta hoje uma atmosfera com conteúdo de dióxido de carbono 100 vezes maior do que a Terra e uma superfície sem água. Acredita-se que o oxigênio molecular também foi removido da atmosfera pelo fluxo hidrodinâmico ou devido a reações com minerais redutores da crosta. Vale lembrar que os ventos solares eram de 30 a 1000 vezes mais intensos nos primeiros bilhões de anos de existência do Sol.

Marte, alvo principal das pesquisas recentes, apresenta-se como um planeta cuja atmosfera sofreu mudanças bruscas nos seus primeiros bilhões de anos de história. As condições marcianas atuais não permitem o desenvolvimento de vida complexa em sua superfície, porém a presença de extremófilos não está descartada; os resultados da missão da sonda Curiosity (NASA/ESA), que desceu no planeta no início de agosto, poderão fornecer evidências a essa hipótese. Os empecilhos ao desenvolvimento da vida são ocasionados pelas condições hostis de sua superfície: baixa pressão atmosférica, ausência de água líquida, temperaturas baixas, aridez, altos níveis de exposição à radiação solar, etc. Entretanto, a atmosfera marciana pode ter sido mais densa no passado (aproximadamente 1 - 3 bars contra 6 mbars atualmente) e composta por gases de efeito estufa, como o $\mathrm{CO}_{2}$. Kasting (1991), argumenta que esse gás e o vapor de água não poderiam manter, sozinhos, temperaturas acima de $273 \mathrm{~K}$ na superfície de Marte. É possível que a atmosfera marciana tenha sofrido um processo de erosão, facilitado pela sua baixa gravidade superficial e ausência de campos magnéticos efetivos a partir de aproximadamente 700 milhões de anos depois da formação do planeta (Acuna et al., 1998), somados ao intenso fluxo de partículas do vento solar e a impactos com planetesimais massivos.

\subsection{Simulando a Atmosfera Terrestre}

O objetivo principal deste trabalho é verificar a possibilidade de sobrevivência de organismos extremófilos na superfície de planetas e luas de sistemas extrasolares. Simular uma atmosfera com composição semelhante à terrestre e estimar a região em torno das estrelas na qual a temperatura superficial desses corpos estejam nas faixas entre $323-273 \mathrm{~K}$ e $370-190 \mathrm{~K}$, quando submetidos a pressões no intervalo de $10^{-5}-10$ bars - valores que delimitam as Zonas Habitável e Extremófila, respectivamente - é fundamental. O modelo 
utilizado para essa estimativa é o resultado do acoplamento entre a variação da luminosidade estelar, o ciclo silicato-carbono e o balanço global de energia; a variação da pressão parcial de dióxido de carbono é estimada em função do tempo.

O balanço energético que governa o clima de planetas com atmosferas semelhantes à da Terra é baseado em uma equação similar à proposta por Arrhenius (1896):

$$
\frac{L(t)}{4 \pi d^{2}}\left[1-A\left(a_{s}, T_{s}, \mu, p\right)\right]=4 F\left(T_{s}, p\right),
$$

onde $L(t)$ é a luminosidade solar, $d$ a distância orbital do planeta, $A$ o albedo atmosférico, $T_{s}$ a temperatura superficial, $\mu$ o ângulo zenital da estrela, $p$ a pressão parcial de $\mathrm{CO}_{2}$ na superfície, $a_{s}$ o albedo superficial e $F$ o fluxo infravermelho que deixa o planeta.

O modelo utiliza as parametrizações obtidas por Williams et al. (1997), estando apto a simular atmosferas contendo 1 bar de $N_{2}$ e quantidades variáveis de $\mathrm{CO}_{2}$ e vapor de $\mathrm{H}_{2} \mathrm{O}$, sendo o gás oxigênio excluído pela premissa de se investigar planetas com atmosferas primitivas. O albedo planetário é o parâmetro físico que representa o retorno de parte da energia solar incidente no planeta ao espaço e está fortemente correlacionado com o conteúdo atmosférico dele. Esse retorno é consequência de interações com a atmosfera e com a superfície planetária, sendo dependente do deslocamento dos fótons dentro dela, que por sua vez é uma função do ângulo zenital solar, assim como do albedo da superfície. Quantidades elevadas de $\mathrm{H}_{2} \mathrm{O}$ e de $\mathrm{CO}_{2}$ também afetam o albedo planetário, pois contribuem para a intensificação do espalhamento Rayleigh e da absorção de radiação. O dióxido de carbono possui uma seção de choque para o espalhamento Rayleigh 2,5 vezes maior que a do nitrogênio; a água, além de ser um espalhador Rayleigh eficiente é também um ótimo absorvedor no infravermelho próximo. Nesse modelo, a água atua como um intensificador do efeito estufa a partir de temperaturas superiores a $360 \mathrm{~K}$.

As parametrizações para a descrição do comportamento assumido pelo albedo frente à variação da pressão parcial de $\mathrm{CO}_{2}$ foram obtidas através do Radiative Convective Model utilizado por Kasting $(1998,1991)$, considerando a estratosfera isotérmica e a troposfera totalmente saturada com vapor de água. Para temperaturas superficiais variando na faixa de 190 - $370 \mathrm{~K}$, Williams et al. (1997) determinaram duas equações empíricas que descrevem o comportamento do albedo no topo da atmosfera para valores de pressões parciais de dióxido de carbono na superfície, que variam dentro do intervalo de $10^{-5}-10$ bars, 
considerando $0<a_{s}<1$ e $0<\mu<1$. Essas equações foram modificadas de acordo com as necessidades inerentes a este trabalho, ou seja, albedo de superfície médio igual a 0,3 e ângulo zenital solar $\mu=60^{0}$ :

$$
\begin{aligned}
& A\left(a_{s}, T_{s}, \mu, p\right)=-0,4627159900+0,7318405000 T_{s}-0,172358500010^{-1} p \\
& \quad+0,985810000010^{-4} p T_{s}-0,165550000010^{-4} T_{s}^{2}+0,658170000010^{-3} p^{2},
\end{aligned}
$$

para $p / 190<T_{s}<280 K \mathrm{e}$

$$
\begin{aligned}
& A\left(a_{s}, T_{s}, \mu, p\right)=1,524143330-0,696891500010^{-2} T_{s}+0,519150000010^{-2} p \\
& \quad+0,537140000010^{-4} p T_{s}+0,926900000010^{-5} T_{s}^{2}-0,413270000010^{-3} p^{2},
\end{aligned}
$$

para $p / 280<T_{s}<370 K$.

Os erros desses ajustes foram estimados em 7, 58 e 4,66 W.m $\mathrm{m}^{-2}$, respectivamente.

A figura 5.4 descreve o comportamento do albedo planetário descrito pelas equações acima.

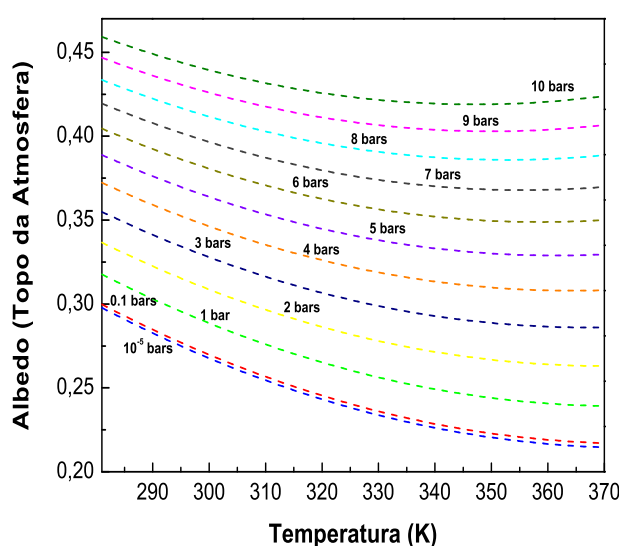

(a)

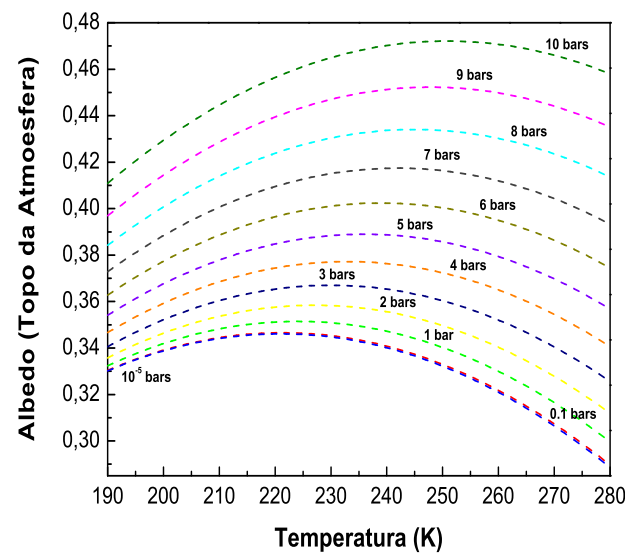

(b)

Figura 5.4: Comportamento do albedo planetário no topo da atmosfera para valores de albedo superficial médio igual a 0,3 e ângulo zenital solar $\mu=60^{\circ}$. (a): valores do albedo para o intervalo de temperatura entre $280<T_{s}<370 \mathrm{~K}$. (b): valores do albedo para o intervalo de temperatura entre $190<T_{s}<280 \mathrm{~K}$.

A equação que representa o escape do fluxo infravermelho (comprimentos de onda longos) emitido pelo planeta em direção ao espaço foi obtida seguindo os mesmos procedimentos utilizados na parametrização dos albedos planetários, com um erro estimado em 
aproximadamente $4,56 \mathrm{~W} \cdot \mathrm{m}^{-2}$. A redução do escape do fluxo infravermelho pela absorção de nuvens de água é simulada pela subtração do valor $14,06 \mathrm{~W} \cdot \mathrm{m}^{-2}$ da equação abaixo, que representa esse processo (Williams et al., 1997):

$$
\begin{gathered}
F\left(p, T_{s}\right)=-4,591020-0,771472700010^{-4} \ln (3030,303030 p)-2,794778 T_{s} \\
-0,324475300010^{-2} \ln (3030,303030 p) T_{s}-0,354740600010^{-3} \ln (3030,303030 p)^{2} \\
+0,221210800010^{-1} T_{s}^{2}+0,222914200010^{-2} \ln (3030,303030 p)^{2} T_{s} \\
+0,308849700010^{-4} \ln (3030,303030 p) T_{s}^{2}-0,278981500010^{-4} \ln (3030,303030 p)^{2} T_{s}^{2} \\
-0,344297300010^{-2} \ln (3030,303030 p)^{3}-0,336193900010^{-4} T_{s}^{3} \\
+0,917316900010^{-2} \ln (3030,303030 p)^{3} T_{s}-0,777519500010^{-4} \ln (3030,303030 p)^{3} T_{s}^{2} \\
-1,67911200010^{-7} \ln (3030,303030 p) T_{s}^{3}+6,59099900010^{-8} \ln (3030,303030 p)^{2} T_{s}^{3} \\
+1,52812500010^{-7} \ln (3030,303030 p)^{3} T_{s}^{3}-0,336756700010^{-1} \ln (3030,303030 p)^{4} \\
-0,163190900010^{-3} \ln (3030,303030 p)^{4} T_{s}+0,366387100010^{-5} \ln (3030,303030 p)^{4} T_{s}^{2} \\
-9,25564600010^{-9} \ln (3030,303030 p)^{4} T_{s}^{3},
\end{gathered}
$$




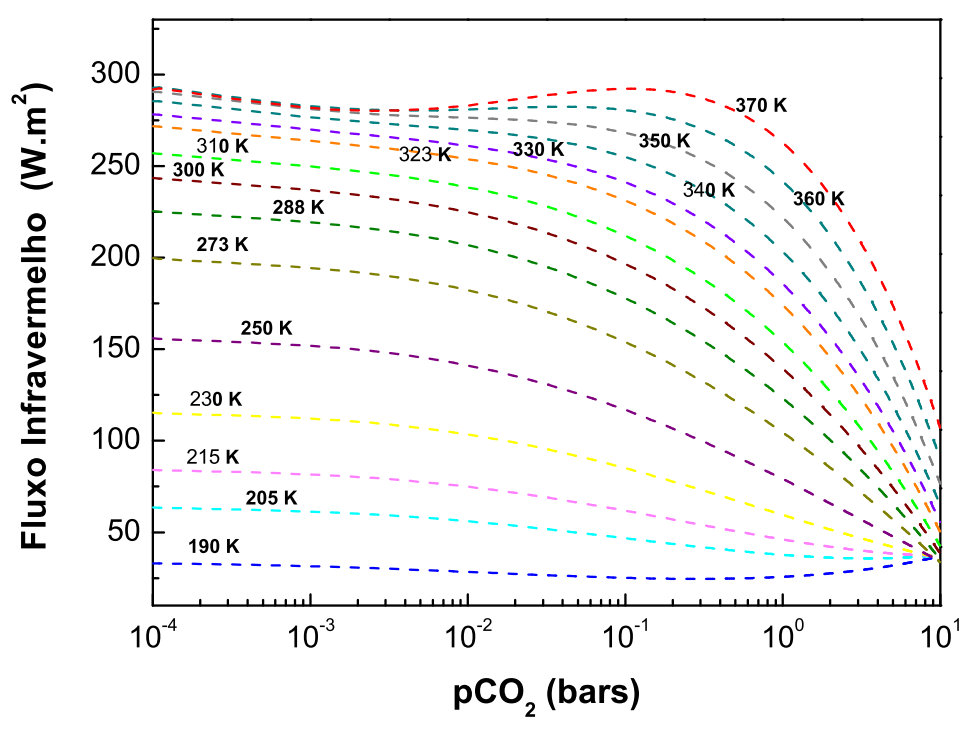

Figura 5.5: Fluxo infravermelho que deixa o planeta em função da pressão parcial de dióxido de carbono para diversos valores de temperatura.

A equação do balaço energético pode ser resolvida numericamente utilizando-se as equações $1.7,1.8,1.10,5.20,5.21$ e 5.22 , resultando em:

$$
d=\sqrt{\frac{L(t)\left[1-A\left(a_{s}, T_{s}, \mu, p\right)\right]}{16 \pi F\left(T_{s}, p\right)}},
$$

onde $d$ é o raio da órbita do planeta. Ela pode ser reescrita de forma mais simples definindose o parâmetro $\xi=\frac{\left[1-A\left(a_{s}, T_{s}, \mu, p\right)\right]}{F\left(T_{s}, p\right)}$ :

$$
d \sim \sqrt{L(t) \times \xi}
$$

O parâmetro $\xi$, representa o balanço não linear entre a quantidade de energia que é injetada e a que é perdida pelo planeta. Portanto, a distância orbital ótima para a sobrevivência de organismos na superfície de planeta e luas, depende da luminosidade estelar, do balanço de energia representado pelo termo $\xi$ e pelas condições geodinâmicas desses corpos, que já estão levadas em conta nas equações parametrizadas apresentadas anteriormente. 
Este trabalho exibe situações importantes envolvendo sistemas planetários, evolução estelar e suas interações com micro-organismos extremófilos, mas o modelo utilizado para simular um conteúdo atmosférico semelhante ao da Terra possui limitação quanto ao limite superior de temperatura, podendo alcançar apenas valores próximos de $370 \mathrm{~K}$. Além disso, a utilização de equações parametrizadas pré-estabelecidas, descrevendo o comportamento de vários parâmetros importantes da atmosfera, impossibita alterações significativas no modelo. 
Capítulo 6

\section{Satélites Naturais Extrasolares}

Nos últimos anos, a descoberta de uma grande quantidade de exoplanetas em diversos sistemas extrasolares fez com que surgissem debates pautados pela seguinte questão: existem satélites naturais desses planetas, também conhecidos como exoluas? A resposta lógica é positiva e pode-se ir além, ou seja, investigar se esses objetos podem ser estáveis em períodos de giga anos (1 G ano $=10^{9}$ anos $)$, se possuem massa e estão próximos de seus planetas hospedeiros o suficiente para manterem processos geodinâmicos ativos, ou ainda, se estão localizados nas Zonas Habitável ou Extremófila de seus sistemas planetários e, é claro, a questão mais instigante: esses satélites poderiam abrigar vida?

O motivo da forte expectativa a respeito da confirmação da existência de satélites orbitando planetas extrasolares tem origem nas observações do Sistema Solar, na construção de instrumentos e no aperfeiçoamento de técnicas capazes de detectar corpos cada vez menos massivos. O Sistema Solar abriga uma grande quantidade de corpos orbitando planetas de composições, tamanhos e distâncias orbitais distintas. Dentre esses corpos, destacam-se Titã por possuir uma atmosfera bastante densa, Io e Enceladus por apresentarem intensa atividade, além de Europa, que provavelmente possui um oceano subterrâneo de água líquida, interligado com sua superfície. Entretanto, quando se considera a possibilidade de detecção de satélites orbitando planetas além do Sistema Solar, é esperado, devido às limitações instrumentais e das técnicas utilizadas, detectar aqueles com massas próximas a uma massa terrestre, orbitando planetas gigantes.

No Sistema Solar, observam-se duas classes distintas de satélites que orbitam planetas gigantes: a primeira é composta por satélites chamados regulares, possui órbitas progressivas (velocidade angular do satélite no mesmo sentido da velocidade angular do planeta), 
aproximadamente planas e circulares, muito próximos do planeta hospedeiro; já a segunda, conhecidos como satélites irregulares, é composta por corpos menores, com órbitas de elevada excentricidade e elevada inclinação, com movimento em geral retrógrado (velocidade angular do satélite no sentido inverso da velocidade angular do planeta) e mais afastados do planeta hospedeiro. Apresentar-se-á nesse trabalho uma estimativa da zona de habitabilidade (expandida a fim de considerar a possibilidade da existência de organismos extremófilos) para possíveis satélites extrasolares orbitando planetas massivos, baseada nos dados físicos da estrela central do sistema planetário, na estabilidade orbital e na interação de maré entre o planeta hospedeiro e a exolua.

\subsection{Exoluas e Astrobiologia}

Satélites naturais extrasolares ou exoluas podem ser definidos como objetos com superfície sólida ou líquida que orbitam planetas extrasolares. Essa classe de objetos traz para a comunidade científica grandes desafios relacionados à sua detecção, já que tais satélites devem apresentar valores de raio e massa muito pequenos. Entretanto, estes mesmos objetos são interessantes para a Astrobiologia, uma vez que há possibilidade de poderem abrigar organismos, extremófilos ou não, em suas superfícies. Nesse caso, estas luas, quando localizadas nas Zonas Habitável ou Extremófila, deveriam apresentar massas suficientes para reterem uma atmosfera e até mesmo apresentarem atividade geológica, favorecendo o desenvolvimento de ambientes semelhantes aos observados na Terra. Outra possibilidade é a de que, mesmo se tais luas estiverem fora da zona de habitabilidade de seu sistema planetário ou forem menos massivas, possam manter por longo tempo processos geodinâmicos necessários à manutenção de uma atmosfera e de oceanos com água no estado líquido, devido às interações de maré com o planeta, apresentando também condições necessárias ao desenvolvimento da vida. O estudo destes ambientes é um tema desafiador e extraordinariamente motivador.

\subsection{Processo de Formação de Satélites Naturais (Exoluas)}

Os principais interesses desta pesquisa no estudo de exoluas são: o exame das características de um conjunto de possíveis satélites regulares orbitando planetas gigantes nas 
Zonas Habitável ou Extremófila de sistemas extrasolares e a possibilidade da ratificação da hipótese de existência de organismos extremófilos constituindo comunidades na superfície ou sub-superfície destes satélites. Tal tarefa inicia-se com a compreensão, mesmo que mínima, do processo de formação das exoluas.

Baseado nos estudos relativos ao Sistema Solar, é possível apontar para a existência de duas classes de satélites: os satélites regulares e os satélites irregulares. A teoria que descreve o processo de formação de planetas e seus satélites está em aberto e deverá ser ainda tema de muita discussão. Como visto no capítulo 2, há duas hipóteses principais para explicar a formação dos planetas: a acresção nuclear e a instabilidade gravitacional. Existem alguns mecanismos que tentam fornecer respostas para o processo de formação dos satélites: formação a partir do material que compõe o disco protoplanetário (satélites regulares, com órbitas progressivas) (Canup e Ward, 2006) ou por captura gravitacional (Agnor e Hamilton, 2006), impactos ou interações de troca (satélites irregulares, com órbitas retrógradas ou progressivas) (Agnor et al., 1999).

Um fator importante na análise dos sistemas extrasolares é saber qual o mecanismo ou modelo de formação desses objetos, planetas e satélites, favorece a busca por potenciais candidatos. Considerando o primeiro processo de formação, Canup e Ward (2006) propuseram que a massa total de um satélite regular formado em um determinado sistema deve ser aproximadamente $2 \cdot 10^{-4}$ vezes a massa do planeta em torno do qual orbita. Esse valor é baseado na quantidade esperada de material do disco que circunda o planeta no início de sua formação e que, por atração gravitacional, pode coalescer. A região onde um corpo massivo orbitando uma estrela domina a atração gravitacional de partículas em torno de si mesmo é denominada esfera de Hill. Essa região ao redor do planeta, responsável pela captura de material que será fonte da matéria que provavelmente originará as exoluas, irá ajudar na imposição de um dos limites de estabilidade e habitabilidade dos satélites nesta pesquisa. De acordo com o limite de Canup e Ward (2006), a formação de uma exolua com massa de aproximadamente 0,23 massas terrestres só seria possível caso o planeta hospedeiro possuísse uma massa de aproximadamente 3,62 massas de Júpiter.

Mecanismos distintos do modelo de acresção nuclear não impõem muitas restrições às propriedades ou à origem dos satélites, abrindo espaço para a construção de cenários onde eventos como captura, impactos ou interações de troca podem acontecer entre objetos com 
ampla faixa de valores de massa, conduzindo a uma grande variedade de possibilidades, favoráveis ou não, à formação de um sistema estável. Tritão, satélite de Netuno, é tido como um exemplo de captura: possui órbita circular, movimento retrógrado, plano orbital inclinado em relação aos outros satélites regulares netunianos e aquecimento por forças de maré, responsável pela observação em sua superfície de geysers de nitrogênio líquido pela sonda espacial Voyager 2 em 1989. Espera-se que o segundo processo responsável pela formação de satélites irregulares deva ser mais favorável à formação de sistemas estáveis.

\subsection{Composição dos Satélites do Sistema Solar}

Os satélites regulares existentes no Sistema Solar são compostos principalmente por gelo, silicatos e ferro. Essa composição se deve ao processo de formação dos planetas gigantes que ocorreu além do limite conhecido como snow-line, região onde o gelo não sublimou, permitindo que satélites com origens nessas localidades tenham acumulado grande quantidade de gelo durante sua formação. Porém, deve-se lembrar que satélites extrasolares com massas aproximadamente iguais à massa terrestre podem ser capturados por exoplanetas gigantes e terem composições semelhantes a de planetas como Mercúrio, Vênus, Terra e Marte, pois podem ter sido originados em condições e regiões distintas das encontradas além da região conhecida como snow line do Sistema Solar. A tabela 6.1 apresenta algumas características dos principais satélites do Sistema Solar.

Tabela 6.1 - Características dos principais satélites do Sistema Solar.

\begin{tabular}{ccccccc}
\hline \hline Satélite & Massa $(\mathrm{Kg})$ & Densidade $\left(\mathrm{g} / \mathrm{cm}^{3}\right)$ & Período (dias) & Raio $\left(10^{3} \mathrm{Km}\right)$ & Excentricidade & Inclinação $\left({ }^{0}\right)$ \\
\hline \hline Io & $8,90.10^{22}$ & 3,55 & 1,77 & 422 & 0,004 & 0,04 \\
\hline \hline Europa & $4,80.10^{22}$ & 3,01 & 3,55 & 671 & 0,009 & 0,47 \\
\hline \hline Ganymede & $1,48.10^{23}$ & 1,95 & 7,15 & 1070 & 0,002 & 0,21 \\
\hline \hline Titã & $1,40.10^{23}$ & 1,89 & 15,95 & 1222 & 0,029 & 0,33 \\
\hline \hline Enceladus & $7,40.10^{19}$ & 1,13 & 1,37 & 238 & 0,005 & 0,00 \\
\hline \hline Tritão & $2,15.10^{22}$ & 2,07 & 5,88 & 355 & 0,000 & 157,30 \\
\hline \hline
\end{tabular}

Dentre os satélites tabelados, somente Tritão possui órbita retrógada. 


\subsection{Estabilidade de Satélites Naturais Extrasolares}

Planetas perdem suas luas através de dois mecanismos principais: i) satélites muito próximos a seus planetas hospedeiros podem ser destroçados pelas forças de maré ou por impactos; ii) luas orbitando regiões muito afastadas poderão sair do campo de influência planetário e ter suas órbitas influenciadas pelo campo gravitacional estelar. Nesta pesquisa, a região de estabilidade orbital de uma exolua em torno de um exoplaneta massivo será delimitada por dois limites (raios orbitais). O primeiro limite será caracterizado pela menor órbita em que um satélite pode estar localizado e permanecer intacto sob a influência das forças de maré provocada pela interação gravitacional com seu exoplaneta hospedeiro. Esse limite, conhecido como raio de Roche, é estimado usando a equação (Binney e Tremaine, 1987):

$$
R_{R}=2,44 R_{p}\left(\frac{\rho_{p}}{\rho_{m}}\right)^{\frac{1}{3}}=2,44\left(\frac{4 \times \pi}{3}\right)^{-\frac{1}{3}}\left(\frac{M_{p}}{\rho_{m}}\right)^{\frac{1}{3}}
$$

Na equação acima, $\rho_{p}$ e $\rho_{m}$, são as densidades médias do exoplaneta e de sua exolua respectivamente. Nota-se, pois, que o limite interno de estabilidade desses objetos dependerá de sua composição.

Conclui-se, através da análise da figura 6.1, que a extensão do limite de Roche, tanto para Exoplanetas Gigantes (EPG) quanto para Super-Terras (ST), depende da composição da lua que orbita tais classes de planetas. Logo, exoluas com composição semelhante à composição terrestre $\left(\rho=5,55 \mathrm{~g} \cdot \mathrm{cm}^{-3}\right)$ terão um raio de Roche menor do que outra, com composição similar a do satélite Titã $\left(\rho=1,89 \mathrm{~g} \cdot \mathrm{cm}^{-3}\right)$ : por exemplo, uma lua com composição igual a de Titã, orbitando uma Super-Terra com massa igual a seis massas terrestres, como é o caso do exoplaneta Gliese 581d, pode permanecer estável a partir de uma distância aproximadada de 0,56 raios de Júpiter da superfície do exoplaneta hospedeiro. Fazendo a mesma análise, mas considerando um Exoplaneta Gigante, com massa igual a duas vezes a massa de Júpiter, a distância de estabilidade passa a ser de aproximadamente 2,7 raios de Júpiter. A informação contida na extensão do raio de Roche será útil na estimativa do provável período orbital de exoluas por meio da terceira lei de Kepler.

O limite externo para a órbita de um satélite em torno de um exoplaneta será caracterizado por uma função do raio de Hill, que define uma região esférica em torno do exoplaneta em que determinado objeto não sofre perturbações gravitacionais ocasionadas pela estrela 


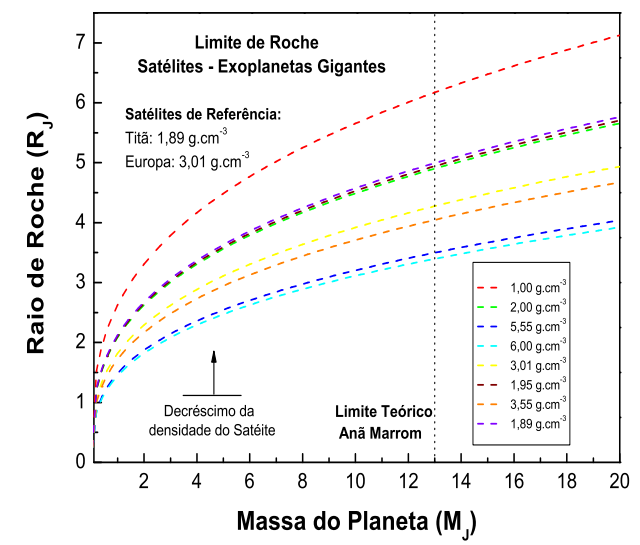

(a)

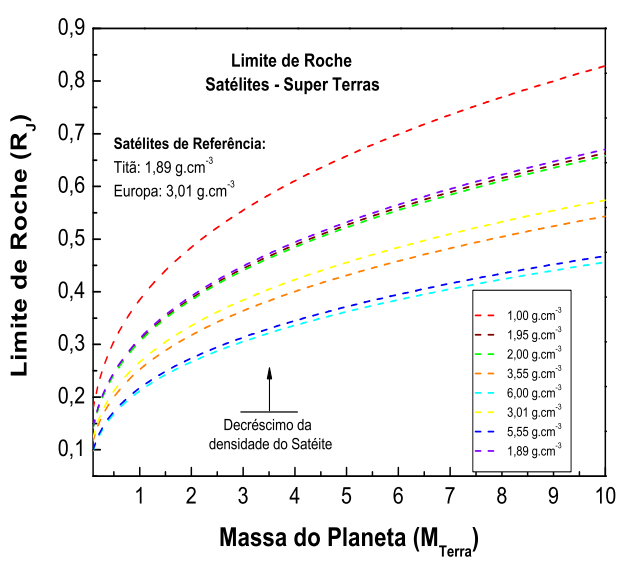

(b)

Figura 6.1: Limite de Roche para exoplanetas. (a): extensão do raio de Roche para satélites que orbitam planetas gigantes. (b): extensão do raio de Roche para satélites orbitando Super Terras.

do sistema planetário. A esfera de Hill é calculada pela equação:

$$
R_{H}=a_{p}\left(\frac{M_{p}}{3 M_{s}}\right)^{\frac{1}{3}}
$$

Nota-se que a esfera de Hill possui uma dependência com relação ao semi-eixo maior do planeta $a_{p}$, sendo que planetas com curtos períodos de translação terão menores $R_{H}$.

Estudos conduzidos por Domingos et al. (2006), baseados em estudos anteriores (Barnes e O’Brien, 2002), apontam que o limite externo máximo de estabilidade orbital é uma função do raio de Hill e que este limite difere quanto às caracterísiticas da velocidade angular do satélite e aos valores de excentricidades do exoplaneta, $e_{p}$, e de seu satélite, $e_{m}$. Logo, tais limites serão distintos ao considerar-se satélites com velocidades angulares no sentido da velocidade angular do exoplaneta ou em sentido retrógrado (Domingos et al., 2006):

$$
\begin{aligned}
& R_{\text {máx }, p}=R_{H} 0,4895\left(1-1,0305 e_{p}-0,2738 e_{m}\right) \\
& R_{\text {máx }, r}=R_{H} 0,9309\left(1-1,0764 e_{p}-0,9812 e_{m}\right)
\end{aligned}
$$

As equações acima determinam os limites externos máximos para satélites com movimento orbital progressivo, $R_{\text {máx,p }}$, e para satélites com movimento orbital retrógrado, $R_{\text {máx }, r}$. 
Luas geradas através de impactos de planetas terrestres com planetesimais exibem órbitas circulares que podem estar inclinadas arbitrariamente em relação ao plano orbital do planeta hospedeiro; esses corpos localizam-se a distâncias orbitais relativamente próximas ao planeta e adquirem uma fração da massa do corpo com o qual interagiu, além de sofrerem diversos tipos de processos migratórios (Atobe e Ida, 2007). Considerando que a evolução rotacional do planeta não é dominada pela lua (em razão da pequena massa da lua ou porque a história rotacional do planeta foi dominada pela força de maré estelar), a modificação da equação A.5 ajuda na descrição da variação do semi-eixo maior do satélite (Barnes e O’ Brien, 2002):

$$
a_{m}=\left[R_{R}^{\frac{13}{2}}+T \frac{33}{2} \frac{k_{2 p} G M_{m} R_{p}^{5}}{\sqrt{G M_{p}} Q_{p}}\right]^{\frac{2}{13}},
$$

onde $T$ representa o tempo decorrido para se atingir determinada posição orbital. A figura 6.2 representa o processo de formação de luas para planetas do tipo rochosos, com massa igual a da Terra.

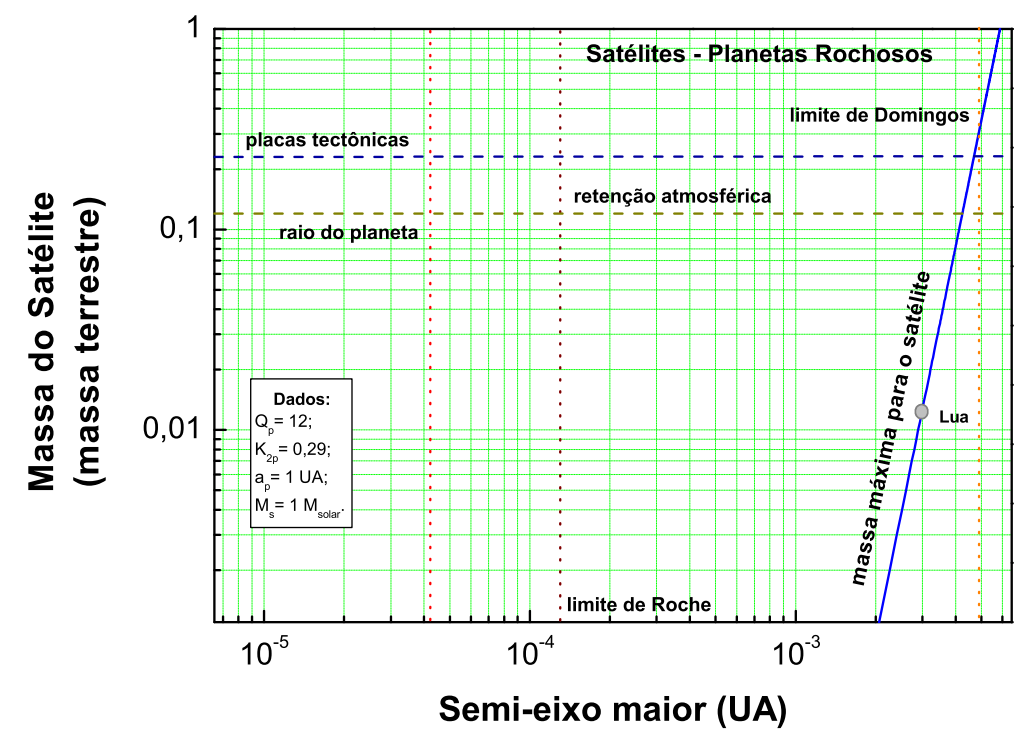

Figura 6.2: Processo de formação de luas para planetas do tipo terrestres. Observa-se que não há luas capazes de reter atmosfera para semi-eixos orbitais distantes do limite de Domingos. A figura ainda indica a posição aproximada do satélite natural terrestre. 
Com a finalidade de estudar a massa máxima que uma exolua, orbitando seu exoplaneta gigante hospedeiro, pode ter em determinada posição orbital estando ela sujeita a uma migração interna no interior das Zonas Habitável ou Extremófila, deve-se considerar o tempo de decaimento orbital (Murray e Dermott, 2000):

$$
T=\frac{2}{33}\left(a_{c r i t}^{\frac{13}{2}}-R_{p}^{\frac{13}{2}}\right) \frac{Q_{p}}{k_{2 p} M_{m} R_{p}^{5}} \sqrt{\frac{M_{p}}{G}},
$$

desde que seja definido o semi-eixo maior crítico, $a_{c r i t}=a_{m}$, que é uma função do raio de Hill. O raio do planeta representado pelo termo $R_{p}^{\frac{13}{2}}$ pode ser desprezado, pois é bem menor que $a_{c r i t}$. Com esse procedimento é possível estimar a massa máxima para a exolua de forma mais simplificada:

$$
M_{m}^{m a ́ x}=\frac{2}{33}\left(f\left(R_{H}\right)\right)^{\frac{13}{2}} \frac{Q_{p}}{k_{2 p} R_{p}^{5} T} \sqrt{\frac{M_{p}}{G}}
$$

O objetivo principal deste trabalho é verificar as condições de habitabilidade em sistemas onde a excentricidade do exoplaneta e de sua lua tendem a zero $\left(e_{m}=e_{p} \rightarrow 0\right)$, já que órbitas muito excêntricas são uma limitação ao desenvolvimento e manutenção de ambientes extraterrestres semelhantes aos encontrados na Terra. Assim, a equação acima pode ser reescrita como:

$$
M_{m}^{\text {máx }}=\frac{2}{33}\left[\frac{\left(f a_{p}\right)^{3}}{3 M_{s}}\right]^{\frac{13}{6}} \frac{M_{p}^{\frac{8}{3}} Q_{p}}{k_{2 p} R_{p}^{5} T \sqrt{G}}
$$

Alguns parâmetros envolvidos na determinação da equação 6.8 podem gerar incertezas relacionadas ao estudo do comportamento provável da massa do satélite e sua dependência com a posição orbital do exoplaneta. $Q_{p}$ é o fator adimensional de dissipação por efeito de maré e $\left(f a_{p}\right)$ é uma função do raio de Hill que depende das características do satélite. O parâmetro $Q_{p}$ é muito pouco conhecido para corpos orbitando planetas do Sistema Solar e totalmente incerto para exoplanetas. Seguindo os estudos de Barnes e O' Brien (2002), adotar-se-ão valores de $Q_{p}=10^{5}$ e de $k_{2 p}=0,51$ para planetas gigantes gasosos. Planetas do tipo Netuno possuem valores de $Q_{p}$ entre $10^{4}$ e $10^{5}$; esses parâmetros para planetas do tipo Super Terra variam muito e será adotado o valor de $k_{2 p}=0,3$ e $Q_{p}$ no intervalo de 100 a 500 (Barnes et al., 2008; 2009). O tempo de estabilidade para o satélite será estabelecido segundo o seguinte critério: será utilizada a idade mínima da estrela central, caso seja 
conhecida. Caso contrário, será adotado o valor de $5 G$ anos ( $1 G$ ano $=10^{9}$ anos $)$, já que espera-se que este seja aproximadamente o tempo necessário para o desenvolvimento da vida em cenários cósmicos provavelmente similares ao terrestre. Salienta-se novamente que, há uma expectativa referente à detecção da primeira exolua, pois com os dados advindos desse evento, poder-se-á através da equação 6.8 determinar um valor mínimo para $Q_{p}$.

\subsection{Habitabilidade para Satélites Naturais Extrasolares}

Ao se analisar as condições e mecanismos que fazem do planeta Terra um planeta habitável, características como estar localizado dentro da zona habitável, apresentar uma superfície sólida ou líquida, ter uma atmosfera capaz de proteger a superfície das radiações ionizantes, possuir um campo magnético com intensidade suficiente para proteger a atmosfera dos ventos solares, ser geodinamicamente ativo e contar com um solvente capaz de promover reações bioquímicas, mostram-se essenciais. Além destas características, a análise das condições de habitabilidade para as exoluas deve considerar distâncias orbitais estáveis, ou seja, distâncias em que tais objetos estariam protegidos dos campos gravitacionais estelar e planetário (efeitos como Tidal Locking e rompimento estrutural). Porém, essas luas podem usufruir da obtenção de energia de fontes distintas da estelar, como por exemplo, a advinda de efeitos de maré ou de processos internos (que provavelmente são os responsáveis pela manutenção da atmosfera densa de Titã), e ainda manter válidas algumas condições essenciais de habitabilidade, condições essas, que devido ao seu alto grau de complexidade serão tratadas apenas parcialmente neste trabalho.

\subsection{Conteúdo Volátil de Satélites Naturais Extrasolares}

Acredita-se que a maior parte do conteúdo volátil encontrado em planetas rochosos deve ter sua origem relacionada a eventos de bombardeamento por cometas, meteoros e asteróides (Chyba, 1990). Como observado por Williams et al. (1997), um planeta gigante formado no limite externo do disco circunstelar pode sofrer um processo de migração na direção de regiões mais internas, mantendo estáveis seus satélites. Esse conjunto de fenômenos pode configurar um cenário ideal para bombardeamentos e consequente retenção de volatilidades por corpos menores, ou seja, pelos satélites do sistema. Tal cenário, 
apesar de pouco estudado, oferece subsídios para sustentar a tese de que impactos a baixas velocidades tenham sido o principal mecanismo responsável pela presença de atmosfera em corpos pouco massivos como Titã (Griffith e Zahnle, 1995), mesmo que não explique sua manutenção.

Há várias questões em aberto quando se argumenta a respeito do processo de formação e evolução dos satélites solares. Logo, a pesquisa desses assuntos fornece ferramentas para a compreensão da formação e evolução dos corpos provavelmente existentes em sistemas extrasolares. Além disso, perguntas como: qual o mecanismo responsável pela manutenção da atmosfera densa de Titã?, Há possibilidade de haver fontes internas capazes de realimentar a atmosfera de um satélite semelhante a Titã?, Qual o motivo dos satélites de Júpiter não terem mantido uma atmosfera?, Qual a explicação para a diferença de composição entre os satélites do Sistema Solar?, são questões que ainda carecem de um maior entendimento.

Williams et al. (1997) sugerem que o fato de Titã ter mantido sua atmosfera se deve à sua localização e à velocidade dos impactos sobre sua superfície, responsáveis pela entrega de seu conteúdo volátil. Esses impactos devem ter ocorrido a baixas velocidades e dentro do pequeno poço potencial gravitacional de Saturno, resultando uma menor erosão de sua atmosfera. Essa explicação fortalece a hipótese de que satélites orbitando planetas massivos, como Júpiter (ou maiores ), devem ter o processo de retenção de seus voláteis entregues via cometas ou meteoritos dificultado, pois a interação das partículas carregadas da magnetosfera desses planetas com corpos menores, conduz ao processo de erosão atmosférica (por meio do processo de sputtering) (vide capítulo 5). Modernamente, a maioria dos autores acredita que a atmosfera de Titã é constantemente alimentada por gases provenientes de seu interior (P. Penteado, comunicação privada, 2012). Satélites que se formaram no disco protoplanetário localizado na parte externa da nebulosa estelar podem não necessitar da injeção de voláteis adicionais.

Um dos principais objetivos deste trabalho é a verificação, mesmo que de forma qualitativa, da real possibilidade de um satélite solar ou extrasolar reunir condições mínimas para o desenvolvimento da vida. Assim, a atenção, obviamente, sempre estará voltada aos satélites do Sistema Solar. Como observado por Williams et al. (1997), satélites como Ganymede e Callisto, cujas densidades são de aproximadamente $1,8 \mathrm{~g} . \mathrm{cm}^{-3}$ e 1,5 
g.cm ${ }^{-3}$, respectivamente, apresentam grande quantidade de água e gelo, e uma possível migração para regiões orbitais próximas a da Terra faria com que eles abrigassem oceanos com água líquida de aproximadamente $1000 \mathrm{~km}$. Já Europa e Io, com densidades de aproximadamente $3,5 \mathrm{~g} . \mathrm{cm}^{-3}$ e $3,0 \mathrm{~g} \cdot \mathrm{cm}^{-3}$, respectivamente, são compostos principalmente por rochas. Essas composições distintas devem estar relacionadas com a posição de formação desses satélites: estudos indicam que Europa, constituído principalmente por rocha, formou-se na região interna mais quente da nebulosa circunjoviana (Prinn e Fegley, 1981). Se essa hipótese for verdadeira, e considerando que exoplanetas gigantes formam-se por processos semelhantes aos ocorridos no Sistema Solar, pode-se esperar que satélites formados na parte interna da nebulosa que circunda esses planetas sejam mais propícios a possuirem caracterísitcas semelhantes às da Terra. Na busca por planetas ou luas habitáveis, espera-se encontrar, de forma idealizada, ambientes semelhantes aos terrestres. Entretanto, a observação dos satélites do Sistema Solar mostra um conjunto de objetos com ambientes bem distintos, mas com possibilidade de abrigar organismos vivos, e por isso, interessantes do ponto de vista astrobiológico.

\subsection{Zonas de Habitabilidade de Satélites Naturais Extrasolares}

Um satélite é habitável se estiver localizado em uma região em torno de seu planeta hospedeiro onde alguma fonte de energia seja capaz de manter água líquida em sua superfície. Entretanto, essa definição depende de parâmetros físico-químicos relacionados à estrela central do sistema, ao planeta hospedeiro e à própria lua. Alguns requisitos básicos, além de água líquida, são: massa suficiente para retenção de atmosfera, distância orbital compatível com as Zonas Habitável e Extremófila, aquecimento interno por forças de maré, campo magnético protetor contra partículas energéticas, processos geodinâmicos ativos, posição orbital estável, etc.

William et al. (1997) calcularam, através da equação 5.7, a massa mínima para que um satélite mantenha seus conteúdos voláteis por bilhões de anos; essa estimativa foi obtida considerando uma lua com a densidade do planeta Marte $\left(3,9 \mathrm{~g} . \mathrm{cm}^{-3}\right)$, uma exosfera com sua base $r_{x}=1000 \mathrm{~km}$ e a uma temperatura $T_{x}=2000 \mathrm{~K}$, semelhante à da Terra. Eles concluiram que uma lua com massa maior que $0,07 M_{\oplus}$ poderia manter seus conteúdos de oxigênio e nitrogênio por mais de 4,5 bilhões de anos, considerando o escape térmico. 
Entretanto, a perda atmosférica via recombinação dissociativa do $N_{2}^{+}$é um mecanismo importante:

$$
\begin{aligned}
& N_{2}+h v \rightarrow N_{2}^{+}+e^{*} \\
& N_{2}^{+}+e^{*} \rightarrow N+N
\end{aligned}
$$

Desse modo, Williams et al. (1997) escalaram a perda de nitrogênio no planeta Marte (estimada em $5.10^{5}$ átomos de nitrogênio $\mathrm{cm}^{-2} \cdot \mathrm{s}^{-1}$ ) a uma distância hipotética de 1 $U A\left(\left[\frac{1,52 U A}{1,00 U A}\right]^{2}=2,3\right.$ vezes $)$, obtendo um fluxo de aproximadamente $4.10^{7}$ átomos de nitrogênio $\mathrm{cm}^{-2} \cdot \mathrm{s}^{-1}$. Eles concluiram que um envoltório de nitrogênio semelhante ao terrestre sofreria uma perda de $17 \%$ em 4,5 bilhões de anos, ou seja, luas com conteúdo de $N_{2}$ semelhantes ao terrestre são pouco afetadas pelo processo de recombinação dissociativa, mas luas com envoltórios pobres em nitrogênio perdem sua atmosfera ao longo do tempo. Esse processo de erosão atmosférica torna-se desprezível para exoluas com massas $\gtrsim 0,12 M_{\oplus}$, porque a velocidade dos átomos não térmicos de nitrogênio é baixa o suficiente para impossibilitar o escape.

Outro mecanismo importante estudado por Williams et al. (1997) é a perda atmosférica pelo processo de sputtering. O envoltório gasoso de luas que orbitam planetas gigantes pode ser perdido pela sua interação com as partículas carregadas da magnetosfera do planeta hospedeiro. Titã perde seu conteúdo de nitrogênio a uma taxa de $1,2.10^{7}$ átomos $\mathrm{cm}^{-2} \cdot \mathrm{s}^{-1}$ na magnetosfera de Saturno, que possui massa de aproximadamente $0,3 M_{J}$, sendo pouco afetada. Planetas massivos como Júpiter podem ter magnetosferas com altas densidades de partículas carregadas; um satélite orbitando dentro da magnetosfera de Júpiter pode receber fluxos de elétrons da ordem de $4.10^{8} \mathrm{~cm} . \mathrm{s}^{-1}$ (Marte recebe um fluxo proveniente dos ventos solares de $\left.4,8.10^{5} \mathrm{~cm} . \mathrm{s}^{-1}\right)$. Logo, uma lua desprovida de um campo magnético eficiente deve ter sua atmosfera comprometida (a Terra perderia seu conteúdo de $N_{2}$ em aproximadamente $5.10^{8}$ anos). Estudos das características de satélites do Sistema Solar mostram que Ganymede possui massa suficiente para gerar tal campo, impondo um limite aproximado de $0,03 M_{\oplus}$ para que isso ocorra.

Outro parâmetro físico importante na análise das condições de habitabilidade de exoluas é o raio de captura por maré, expresso pela equação 4.5. Uma lua orbitando o planeta 
Júpiter, com período de rotação $P_{0}$ igual a aproximadamente 15 horas, terá o valor desse raio próximo de 96 raios de Júpiter (Williams et al., 1997); isso corresponde a um período orbital de 116 dias. Assim, a estrutura superficial ou atmosférica de satélites submetido a essas condições deve compensar as grandes variações de temperatura oriundas desse fenômeno físico através da transferência de calor (oceanos subsuperficiais ou atmosferas densas). Variações bruscas na temperatura de satélites também podem ser ocasionadas por valores elevados da excentricidade, mas, como mencionado anteriormente, neste trabalho são consideradas apenas órbitas circulares.

Como visto no capítulo 4, o ciclo de silicato-carbono é um processo importante para a garantia das condições mínimas de habitabilidade, pois regula o clima de um planeta ou lua, que apresente superfície em parte seca, através do controle da concentração de $\mathrm{CO}_{2}$ atmosférico; assim, o tectonismo é de extrema importância no reabastecimento da atmosfera com esse e outros gases de efeito estufa. O tectonismo é garantido tanto pelo fluxo interno de calor, quanto pelo conteúdo aquoso do planeta ou satélite. Uma estimativa do aquecimento radiogênico pode ser feita e acredita-se que valores entre 70 e 30 ergs. $\mathrm{cm}^{-2} . \mathrm{s}^{-1}$, referentes à Terra e a Marte, respectivamente, devem ser suficientes para manter esse processo ativo (Williams et al., 1997). Assumindo que o fluxo de aquecimento superficial é proporcional à massa de material radioativo no interior do objeto dividido pela área superficial dele, pode-se escrever:

$$
F_{\text {rad }} \propto \frac{R_{p, m}^{3} \rho_{p, m} e^{-\lambda t}}{R_{p, m}^{2}} \propto R_{p, m}^{3} \rho_{p, m} e^{-\lambda t},
$$

onde $\lambda=1,5.10^{-10}$ anos $^{-1}$ é a constante de decaimento do ${ }^{238} U$, sendo $R_{p, m}$ e $\rho_{p, m}$, o raio e a densidade do planeta ou satélite.

Assumindo que a inatividade tectônica de Marte começou há 2 bilhões de anos, impli-

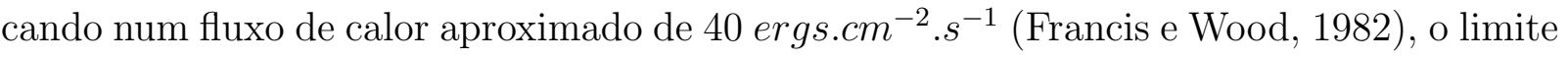
inferior de massa para a manutenção de processos tectônicos é de $\sim 0,23 M_{\oplus}$ (Williams et al., 1997). Entretanto, o aquecimento por força de maré pode fazer com que a necessidade de movimentos tectônicos planetários sejam menos importantes; como por exemplo, o

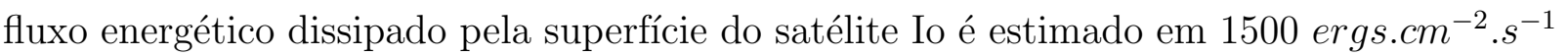
(Scharf, 2006). Peale et al. (1980) desenvolveram uma equação que permite estimar o fluxo de calor gerado na superfície de uma lua devido ao aquecimento por maré: 


$$
H_{T}=\frac{21}{38} \frac{G^{\frac{5}{2}}}{\mu Q_{m}}\left(\frac{3}{4 \pi}\right)^{\frac{5}{3}} e_{m}^{2} \frac{\rho_{m}^{\frac{1}{3}}}{a_{m}^{\frac{15}{2}}} M_{m}^{\frac{5}{3}} M_{p}^{\frac{5}{2}}
$$

Os termos $\mu, a_{m}$ e $Q_{m}$, são a rigidez elástica, o semi-eixo maior da lua e a função de dissipação específica do satélite respectivamente. Pode-se apresentar uma estimativa do fluxo gerado na superfície de uma lua por meio da interação de maré com um planeta Jupiteriano. Esse fluxo, quando atinge valores superiores aos do satélite Io, pode ser responsável por um processo de vulcanismo intenso, além de reciclar a litosfera em escalas de tempo entre $142-3,6.10^{5}$ anos (Blaney et al., 1995; McEwen et al., 2004), dificultando o desenvolvimento de uma biosfera. A figura 6.3 mostra a análise da possível sobrevivência de organismos extremófilos na superfície de um satélite com as características de Europa, orbitando um planeta semelhante a Júpiter.

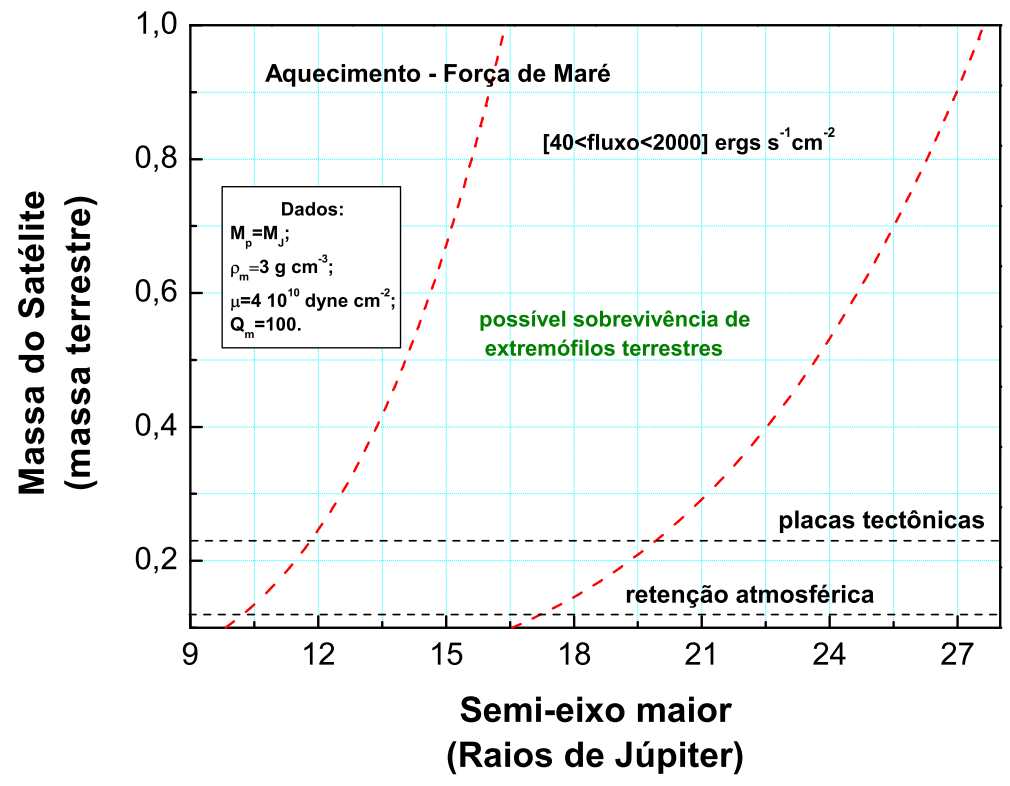

Figura 6.3: A figura aponta a região em torno de um planeta gasoso semelhante a Júpiter onde existe a possibilidade de sobrevivência de micro-organismos extremófilos na superfície de seu satélite hipotético com características de Europa.

As condições mínimas de habitabilidade foram bem determinadas pelos estudos de Williams et al. (1997), porém este trabalho visa contribuir com fatores extras. Será considerado habitável o planeta ou lua que atenda àquelas condições, estejam localizados 
em regiões orbitais estáveis e sejam capazes de sustentar valores de temperatura ou pressão próximos aos tolerados por organismos mesófilos. Porém, ao considerarmos a possibilidade de existência de micro-organismos extremófilos sobrevivendo na superfície desses objetos, o conceito baseado nos parâmetros físico-químicos da definição de corpos celestes habitáveis é expandido; nota-se que essa nova definição exclui a forte dependência relativa à massa mínima na procura de vida extraterrestre. O gráfico 6.4 ajuda a compreensão do conceito.

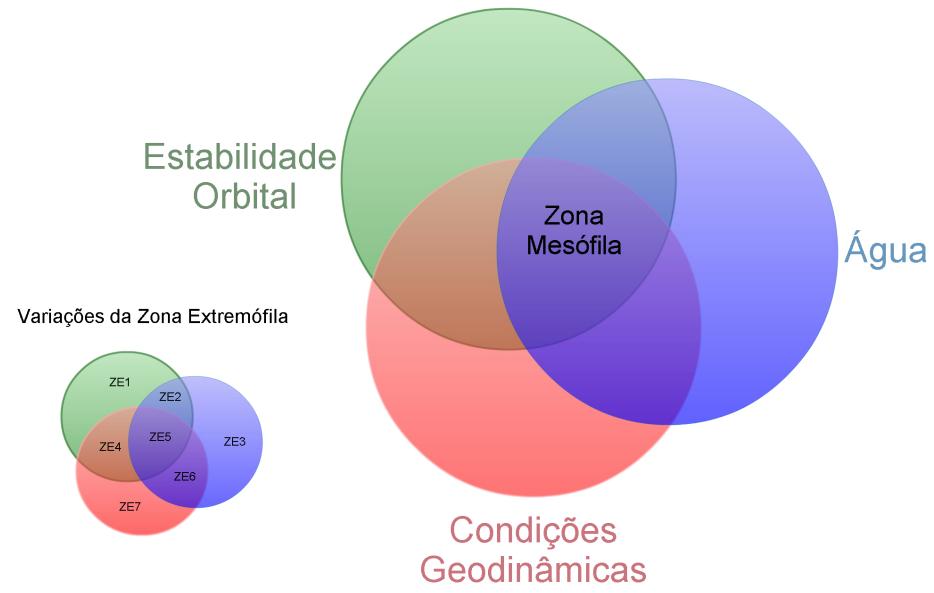

Figura 6.4: Expansão do conceito de habitabilidade. É considerado objeto em condições otimizadas de habitabilidade somente aqueles que satisfazem a intersecção dos três modelos: atmosférico, estabilidade orbital e geodinâmico. Micro-organismos extremófilos podem sobreviver além desse limite.

Através da Lei de Kepler e do modelo de estabilidade orbital, é possível obter uma equação para um intervalo de períodos ao qual satélites estejam aptos a abrigar alguma forma de vida:

$$
P_{h a b}=2 \pi\left[\frac{a_{h a b}^{3}}{G\left(M_{p}+M_{m}\right)}\right]^{\frac{1}{2}}
$$

onde $a_{h a b}$ corresponde aos limites dados pelas equações 6.1 (limite de Roche) e 6.3 (função do raio de Hill). Logo, uma lua apresentará condições ótimas de habitabilidade se estiver na intersecção de todos esses parâmetros físicos, ou seja, deve possuir massa maior que 0,23 $M_{\oplus}$, estar na Zona Habitável e dentro do intervalo $P_{h a b}^{m i n} \leq P_{h a b} \leq P_{h a b}^{m a ́ x}$. Porém, a sobrevivência de organismos extremófilos em planetas ou luas, está além dessa intersecção. 


\section{Capítulo 7}

\section{Análise}

A hipótese de existência de micro-organismos extremófilos nas superfícies de exoplanetas ou na de seus satélites, que utiliza argumentos cognitivos para sustentar sua veracidade, aventura-se num espaço preenchido por um conjunto de conhecimentos que ainda necessita ser melhor estudado; isso porque não há um consenso único sobre os processos fundamentais responsáveis pelo surgimento da vida e tão pouco sobre as condições intrínsecas dos objetos alvos dessa pesquisa, onde acredita-se ser possível encontrá-la. Porém, uma aproximação da realidade pode ser tentada e ela é apresentada a seguir. Com esse propósito, os planetas ou luas presentes serão considerados análogos à Terra, quando analisados frente às limitações que uma atmosfera radiativa e o funcionamento do ciclo silicato-carbono impõe aos limites de habitabilidade observados no Sistema Solar.

\subsection{Habitabilidade para o Sistema Solar}

A primeira parte dessa análise consistiu em verificar se o modelo utilizado era capaz de reproduzir as condições de habitabilidade esperadas. Para isso, escolheu-se o Sistema Solar como contra-prova, já que se conhece nele os possíveis limites para a existência da vida. Resolvendo a equação 5.24 numericamente, é possível determinar os limites interno e externo das Zonas Habitável e Extremófila, segundo a definição utilizada no trabalho (ver capítulo 4). As figuras 7.1 e 7.2 mostram a evolução destes limites em função do tempo e da pressão parcial de $\mathrm{CO}_{2}$. A grande vantagem do método utilizado é apresentar as distâncias orbitais em função da pressão de dióxido de carbono pois, com isso, têm-se informações quanto às reais condições de habitabilidade do planeta.

Através da equação 1.6 é possível estimar o tempo de permanência na sequência princi- 


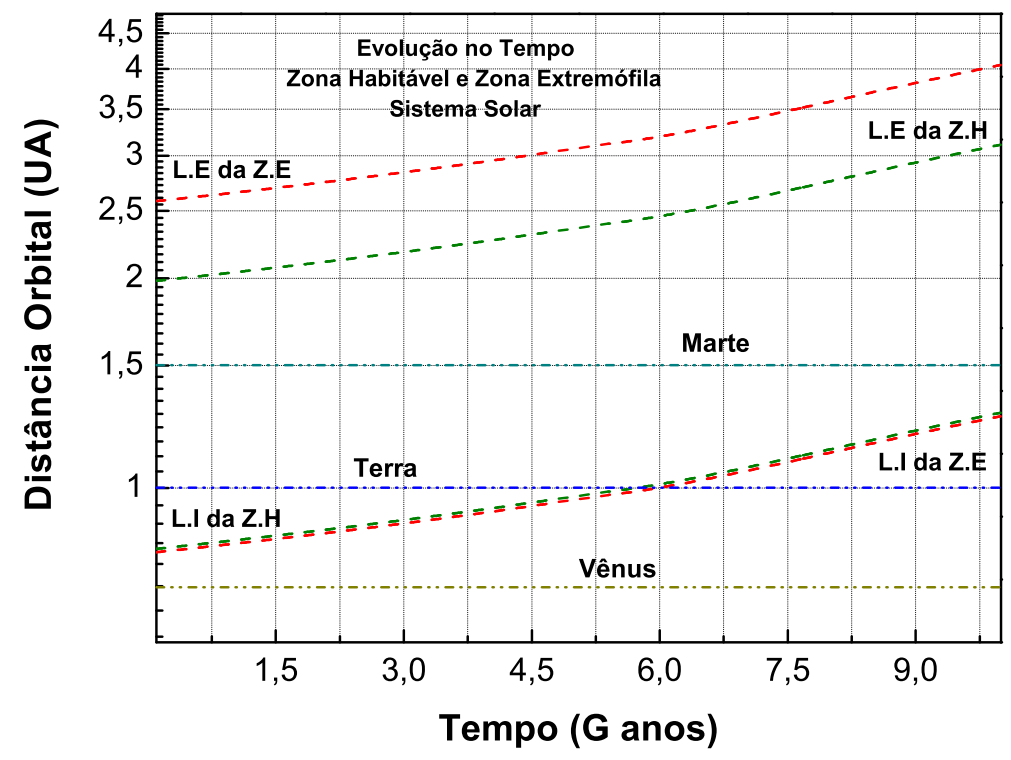

Figura 7.1: Zonas Habitável e Extremófila contínuas para o Sistema Solar. L.I e L.E são os limites interno e externo das Zonas Habitável (Z.H) e Extremófila (Z.E) do sistema.

pal das estrelas que abrigam todos os planetas analisados. O Sol permanecerá na sequência principal por um período aproximado de 10 bilhões de anos, sendo que as Zona Habitável e Extremófila sofrerão deslocamentos devido ao aumento da luminosidade solar. Então, por quanto tempo as condições favoráveis à vida ainda existirão na Terra? A análise das condições de habitabilidade apontam que a Terra permanecerá dentro da Zona Habitável, considerando as pressões atuais de $\mathrm{CO}_{2}\left(3,4.10^{-4}\right.$ bars $)$, até aproximadamente 6 bilhões de anos a partir da formação do Sistema Solar; em 6,5 bilhões de anos, a Terra estará totalmente fora dessa região (figura $7.2(a)$ ), provavelmente passando por um processo de efeito estufa intenso (runaway greenhouse).

Marte, por sua vez, não é habitável pois apesar de estar localizado dentro das Zonas Habitável e Extremófila contínuas (figura 7.1), apresenta baixa pressão atmosférica, dificultando a existência de água líquida na maior parte de sua superfície (figura 7.2 (a)). Porém, o planeta vermelho já pôde oferecer condições de habitabilidade? De acordo com esse modelo, Marte poderia ser considerado habitável, por exemplo, se apresentasse pressões superiores a 1,5 bars de $\mathrm{CO}_{2}$ há aproximadamente 3,8 bilhões de anos, tempo estimado para 


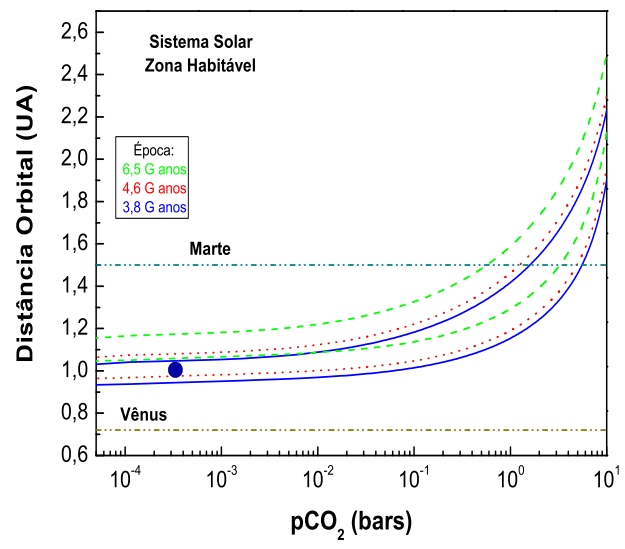

(a)

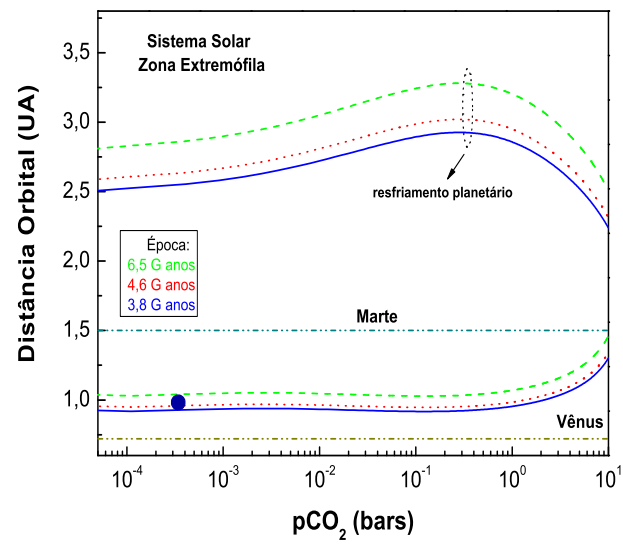

(b)

Figura 7.2: Análise das condições de habitabilidade para o Sistema Solar: (a) e (b) mostram as Zonas Habitável e Extremófila em função da pressão de dióxido de carbono para o Sistema Solar em períodos de tempo aproximados de 3,8, 4,6 e 6,5 bilhões de anos respectivamente.

o surgimento da vida na Terra (ver capítulo 1). Essa observação, somada ao fato de que Marte sempre esteve na Zona Extremófila, ratifica a hipótese de que esse planeta possa ter sido fonte da contaminação terrestre por materiais orgânicos via viagens interplanetárias.

O planeta Vênus, que provavelmente suportou oceanos parecidos com os terrestres, não está dentro das Zonas Habitável e Extremófila em nenhuma época (figura 7.1). Desse modo, pode-se afirmar que a vida em sua superfície é praticamente impossível hoje.

A tabela 7.1 resume algumas das principais características de habitabilidade dos planetas internos do Sistema Solar para 4,56 bilhões de anos (hoje).

Tabela 7.1 - Habitabilidade para o Sistema Solar.

\begin{tabular}{cccccc}
\hline \hline Planetas & Massa Estelar $\left(M_{\odot}\right)$ & $t_{s}($ G anos $)$ & $a_{p}(U A)$ & ZH $(U A)$ & ZE $(U A)$ \\
\hline \hline Mercúrio & 1 & 10 & 0,39 & - & - \\
\hline \hline Vênus & 1 & 10 & 0,72 & - & - \\
\hline \hline Terra & 1 & 10 & 1.00 & $0,95-2,31$ & $0,94-3,02$ \\
\hline \hline Marte & 1 & 10 & 1,50 & $0,95-2,31$ & $0,94-3,02$ \\
\hline \hline
\end{tabular}

Nota-se que a Zona Habitável estende-se a regiões próximas de 2, $40 \mathrm{UA}$ devido ao efeito estufa prolongado inerente às propriedades das nuvens de dióxido de carbono. $\mathrm{O}$ limite exterior da Zona Extremófila, caracterizado por temperaturas superficiais próximas a $190 \mathrm{~K}$ e pressões parciais de $\mathrm{CO}_{2}$ variando na faixa de $10^{-5}$ a 10 bars, apresenta um comportamento surpreendente em pressões próximas de 0,30 bars de dióxido de carbono: 
nota-se que a partir desse momento as distâncias orbitais se reduzem, o que pode ser interpretado como um resfriamento incontrolável do planeta, ou seja, o efeito estufa não é mais capaz de sustentar o aquecimento extra da superfície (o planeta perde energia). Logo, planetas do tipo terrestre com temperatura superficial extremamente baixa e pressão superior a 0,30 bars, certamente devem estar localizados a distâncias orbitais menores para garantir a manutenção de sua temperatura em torno dos $190 \mathrm{~K}$. O fenômeno impõe um limite orbital externo para que tais condições sejam garantidas (figura $7.2(b)$ ).

Assim, nota-se que além da Terra, Marte é o único planeta que pôde ou ainda pode sustentar alguma forma de vida. É possível que micro-organismos extremófilos, como a bactéria $D$. radiodurans e os tardígrados, possam habitar a superfície hostil marciana. Além disso, não é descartada uma bioesfera sub-superficial ou a existência de organismos habitando as regiões polares do planeta. Os planetas gigantes do Sistema Solar não estão aptos a abrigar vida. Porém, como discutido em capítulos anteriores, seus satélites podem ser habitats adequados para micro-organismos extremófilos terrestres.

\subsection{Gliese 581d, um planeta habitável?}

O Sistema Gliese 581 (GL 581) (Udry et al., 2007), localizado na Constelação de Libra (distante 22 anos luz da Terra), possui dois exoplanetas classificados como Super Terras orbitando uma estrela anã vermelha $\left(0,31 M_{\odot}\right)$ : GL $581 c$ e GL $581 d$, com massas aproximadas de 5,4 e 6,0 massas terrestres respectivamente. O estudo das condições de habitabilidade para o sistema aponta que o único planeta capaz de manter uma superfície com água líquida ao longo de sua evolução é o GL 851d.

Na figura 7.3 é mostrada a evolução das Zonas Habitável e Extremófila em função do tempo (ZHC e ZEC) para esse sistema planetário extrasolar. 


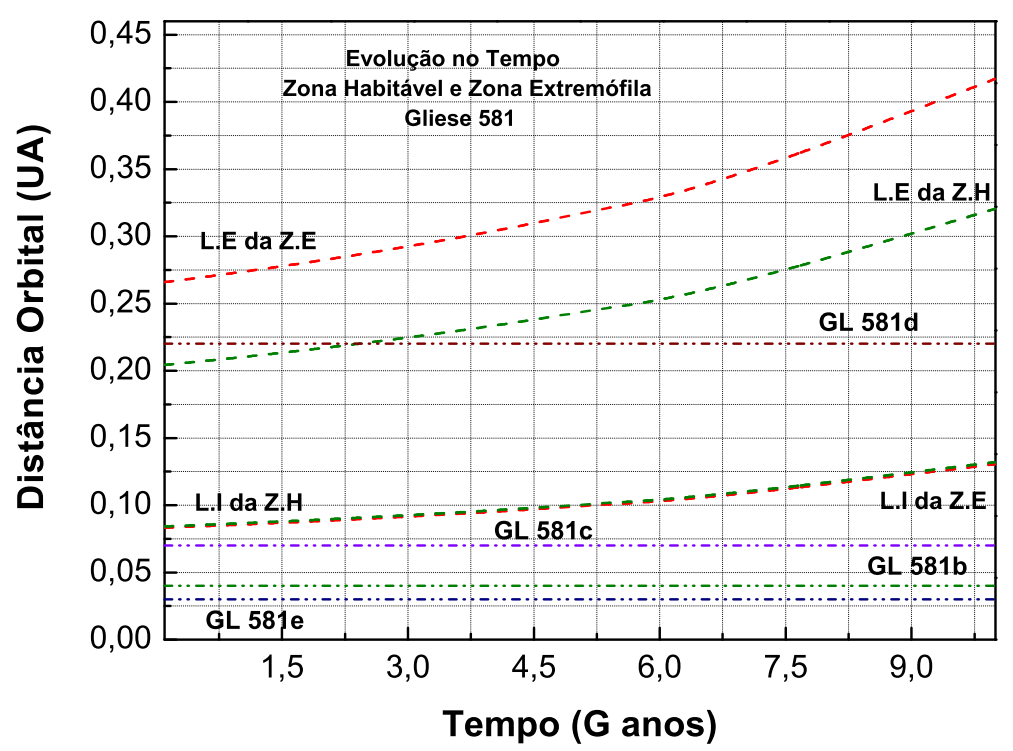

Figura 7.3: Zonas Habitável e Extremófila contínuas para o Sistema Extrasolar Gliese 581. L.I e L.E são os limites interno e externo das Zonas Habitável (Z.H) e Extremófila (Z.E) do sistema.

Observa-se que esse exoplaneta entra na região habitável em aproximadamente 2,2 bilhões de anos e permanece aí até os 10 bilhões de anos, tempo limite deste modelo. Apesar de estar localizado dentro da Zona Habitável Contínua (ZHC), uma análise mais precisa aponta que essa condição, em alguns momentos específicos, é estabelecida somente com a presença de altas concentrações de $\mathrm{CO}_{2}$ na atmosfera do planeta, chegando a valores de 5, 0 bars e 8, 5 bars para tempos estimados em 8, 0 e 5, 0 bilhões de anos após a formação do sistema respectivamente (figura $7.4(a)$ ). Essa alta concentração de $\mathrm{CO}_{2}$ na atmosfera pode ser explicada, por hipótese, como o resultado de processos geológicos intensos ou até mesmo como um indicativo de que a superfície do planeta apresenta grandes quantidades de água, uma vez que o ciclo silicato-carbono pode tornar-se ineficiente em tais condições.

A Zona Extremófila para o sistema é mostrada na figura 7.4 (b); pode-se concluir que todos os planetas desse sistema estão localizados em posições orbitais não compatíveis com essa definição, exceto o planeta extrasolar GL 581d. Essa constatação é importante, pois descarta-se a possibilidade de sobrevivência de micro-organismos extremófilos nas superfícies dos demais planetas. 


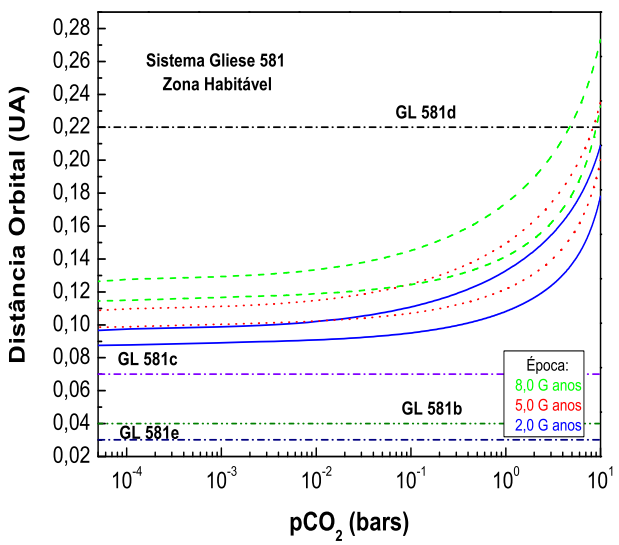

(a)

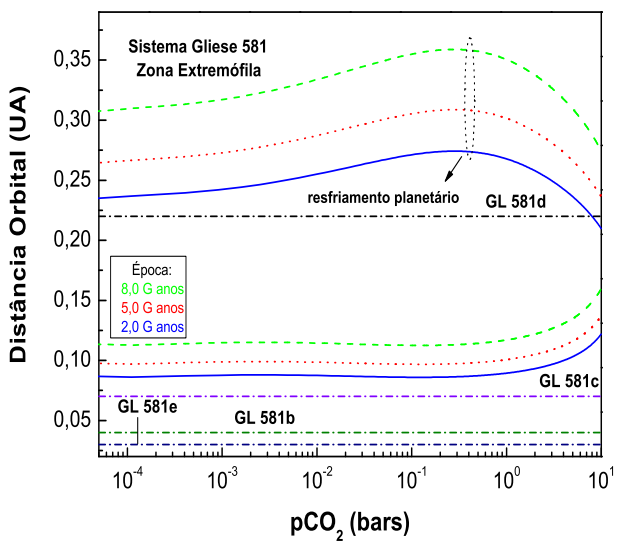

(b)

Figura 7.4: Análise das condições de habitabilidade para o Sistema Gliese 581:(a) e (b) mostram as Zonas Habitável e Extremófila em função da pressão de dióxido de carbono para o Sistema Gliese 581 em períodos de tempo aproximados de 2, 0, 5, 0 e 8, 0 bilhões de anos respectivamente.

Um outro aspecto importante deste trabalho se refere ao acoplamento do modelo atmosférico, apresentado no capítulo 5, com o modelo de estabilidade orbital discutido no capítulo 6. Esse acoplamento permite a análise das condições de habitabilidade para eventuais satélites orbitando exoplanetas gigantes ou Super Terras; a figura 7.5 é obtida através da resolução numérica da equação 6.8, superpondo posteriormente os valores encontrados através do modelo atmosférico. O tempo de estabilidade para o satélite foi estabelecido segundo alguns critérios como a idade mínima da estrela central, se conhecida, ou o valor de 5 bilhões de anos, acreditando que esse seja aproximadamente o tempo necessário para o desenvolvimento do sistema em cenários cósmicos de evolução semelhantes ao do Sistema Solar. O raio dos planetas super Terras foram calculados utilizando as relações entre massa e raio discutidas no capítulo 2; para planetas gigantes gasosos, o raio foi estimado através da densidade média de Júpiter. A análise da figura 7.5 indica que o planeta GL 581d pode abrigar uma lua dentro da Zona Hábitável estelar, mas não massiva o suficiente para garantir as condições de Williams et al. (1997). Nota-se que o valor de $Q_{p}$, apesar de incerto, foi superestimado em duas vezes o maior valor encontrado na literatura e, mesmo assim, o planeta Gliese 581d não parece abrigar uma lua compatível com a definição otimizada de habitabilidade (ver figura 6.4). Provavelmente, o planeta Gliese 581d é apto a abrigar uma lua com massa maior do que a do satélite jupiteriano Europa, tendo possibilidades de abrigar organismos extremófilos em sua superfície. A massa da lua foi estimada em 
aproximadamente $5,58.10^{22} \mathrm{~kg}$ para um valor de $Q_{p}=100$, mas com o aumento desse parâmetro, por exemplo, $Q_{p}=350$, pode-se obter luas mais massivas que Titã. Observa-se que planetas como GL 581d, localizados em distâncias orbitais maiores, podem abrigar exoluas mais massivas.

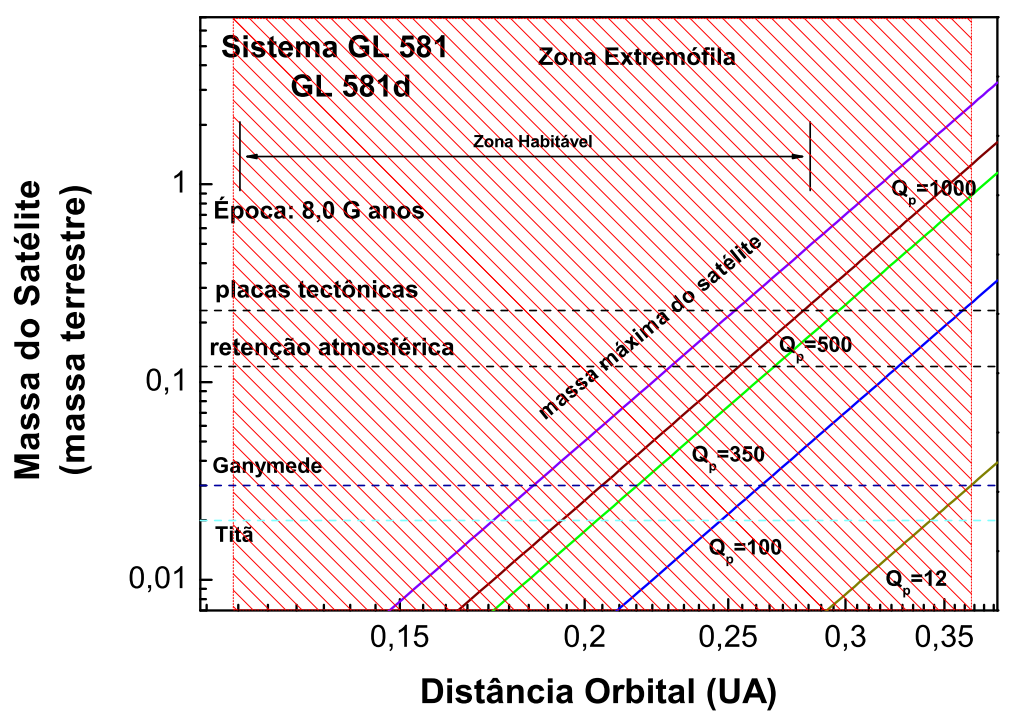

Figura 7.5: Satélites Habitáveis para o exoplaneta Gliese 581d. A abscissa indica a distância orbital do planeta e, a ordenada, a massa de suas prováveis exoluas. As curvas indicam a massa máxima que as exoluas podem apresentar dentro do limite $q=0,01$.

A tabela 7.2 mostra os resultados da análise desse sistema planetário extrasolar. Os planetas fora da Zona Extremófila não foram analisados.

Tabela 7.2 - Habitabilidade para o Sistema Extrasolar Gliese 581.

\begin{tabular}{cccccccc}
\hline \hline Planetas & Massa Estelar $\left(M_{\odot}\right)$ & $t_{s}($ G anos $)$ & $a_{p}($ UA $)$ & ZH $(U A)$ & ZE $(U A)$ & Satélites & P $_{\text {hab }}($ dias $)$ \\
\hline GL 581b & 0,31 & $>10$ & 0,04 & - & - & - & - \\
\hline \hline GL 581c & 0,31 & $>10$ & 0,07 & - & - & - & - \\
\hline \hline GL 581d & 0,31 & $>10$ & 0,22 & $0,12-0,28$ & $0,11-0,36$ & sim & $0,29-13,37$ \\
\hline \hline GL 581e & 0,31 & $>10$ & 0,03 & - & - & - & - \\
\hline \hline
\end{tabular}

Os dados da tabela são referentes às Zonas Habitável e Extremófilas para a idade estimada do sistema que é de aproximadamente 8, 0 bilhões de anos (http://exoplanet.eu/). 


\subsection{Satélite extrasolar orbitando o exoplaneta HD 37124c?}

O Sistema HD 37124 é constituído por uma estrela do tipo G4 V (0,83 $\left.M_{\odot}\right)$ e três exoplanetas gigantes gasosos. Entre esses, o planeta HD 37124c está localizado em uma posição orbital compatível com as definições de Zonas Habitável e Extremófila. O planeta não pode abrigar vida como conhecemos, mas por estar em uma posição privilegiada, espera-se que ele possa ser orbitado por satéltes capazes de sustentar organismos em suas superfícies.

Na figura 7.6 são mostradas as Zonas Habitável e Extremófila Contínuas (ZHC e ZEC) para o sistema. Observa-se que o exoplaneta HD $37124 c$ encontra-se dentro da ZEC em todas as épocas analisadas e entra na Zona Habitável em aproximadamente 6,0 bilhões de anos, lembrando que a idade do sistema é estimada em 3,3 bilhões de anos (http://exoplanet.eu/). As figuras 7.7 (a) e 7.7 (b) apresentam as Zonas Habitável e Extremófila em função do conteúdo atmosférico de dióxido de carbono; através da análise delas, constata-se que o exoplaneta HD 37124c entrará na Zona Habitável a partir de aproximadamente 6,0 bilhões de anos, mas somente para altos valores de pressão parcial de $\mathrm{CO}_{2}$ (10 bars para 6,0 bilhões de anos e 7,3 bars para 8 bilhões de anos). Todavia, o exoplaneta está localizado confortávelmente na Zona Extremófila para uma ampla variedade de pressões. 


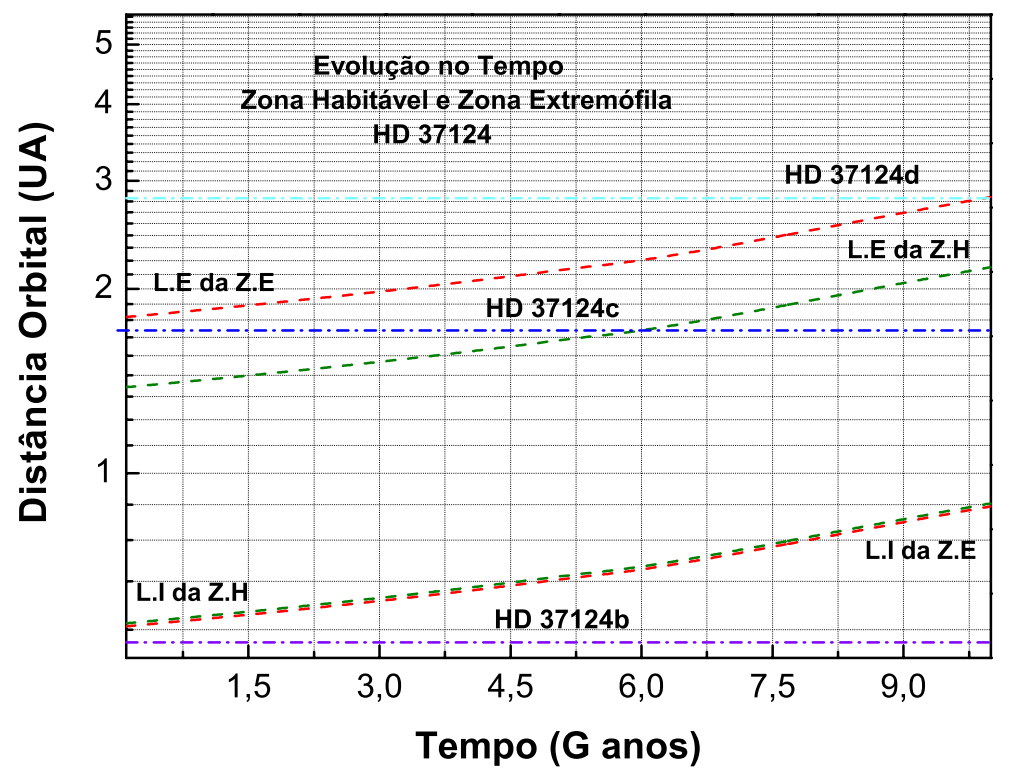

Figura 7.6: Zonas Habitável e Extremófila contínuas para o Sistema Extrasolar HD 37124. L.I e L.E são os limites interno e externo das Zonas Habitável (Z.H) e Extremófila (Z.E) do sistema.

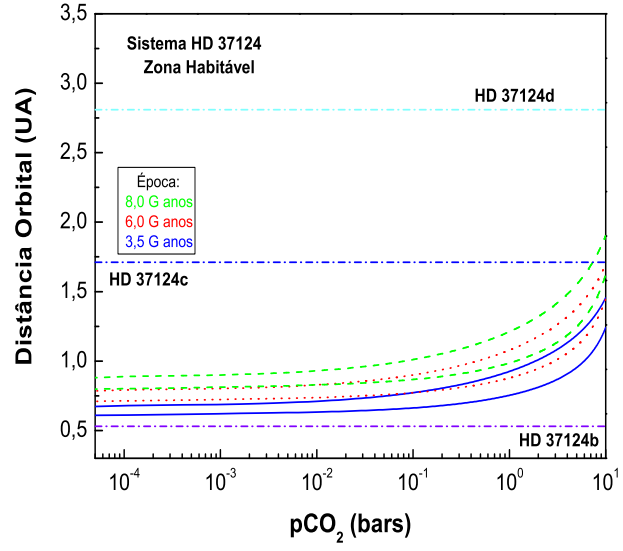

(a)

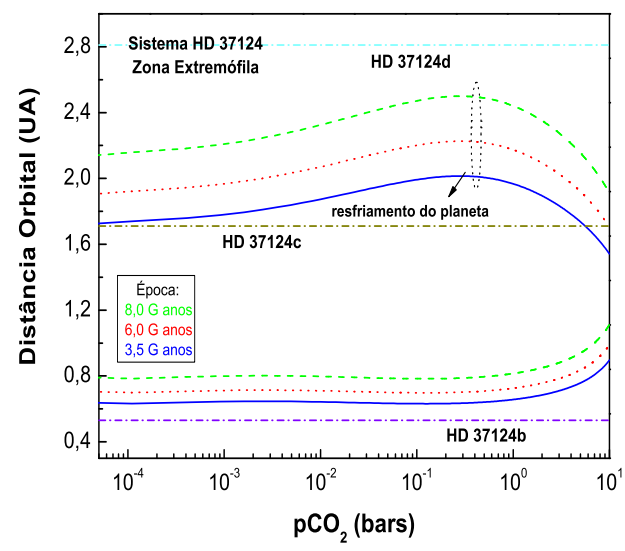

(b)

Figura 7.7: Análise das condições de habitabilidade para o Sistema HD 37124: (a) e (b) mostram as Zonas Habitável e Extremófila em função da pressão de dióxido de carbono para o Sistema HD 37124 em períodos de tempo aproximados de 3,5,6,0 e 8,0 bilhões de anos respectivamente.

A análise da possibilidade do planeta gigante gasoso HD 37124c abrigar uma lua é apresentada na figura 7.8. Observa-se que o exoplaneta pode ser orbitado por uma lua que 
atenda às condições otimizadas de habitabilidade a partir de distâncias aproximadamente iguais ao intervalo de $0,63-1,54 U A$, oferecendo um ambiente provavelmente propício à existência de organismos vivos em sua superfície, considerando que a magnetosfera do planeta não comprometa de forma contundente o conteúdo da atmosfera do satélite natural. Porém, altos valores da razão entre as massas dos exoplanetas gigantes e suas eventuais luas, devem influenciar a rotação do planeta hospedeiro, gerando efeitos não estudados nesse trabalho. Seguindo Weidner e Horne (2010), foi adotado um limite de confiabilidade para o valor máximo de massa das eventuais exoluas. Esse limite é estabelecido na razão entre a massa da lua e de seu planeta hospedeiro: $q=0,01$. Acima desse valor, a massa máxima não pode ser estimada com precisão, podendo apresentar valores menores ou maiores que uma massa terrestre.

De maneira geral, nota-se que exoplanetas gigantes na Zona Habitável são os principais candidatos a abrigarem luas com características semelhantes a da Terra.

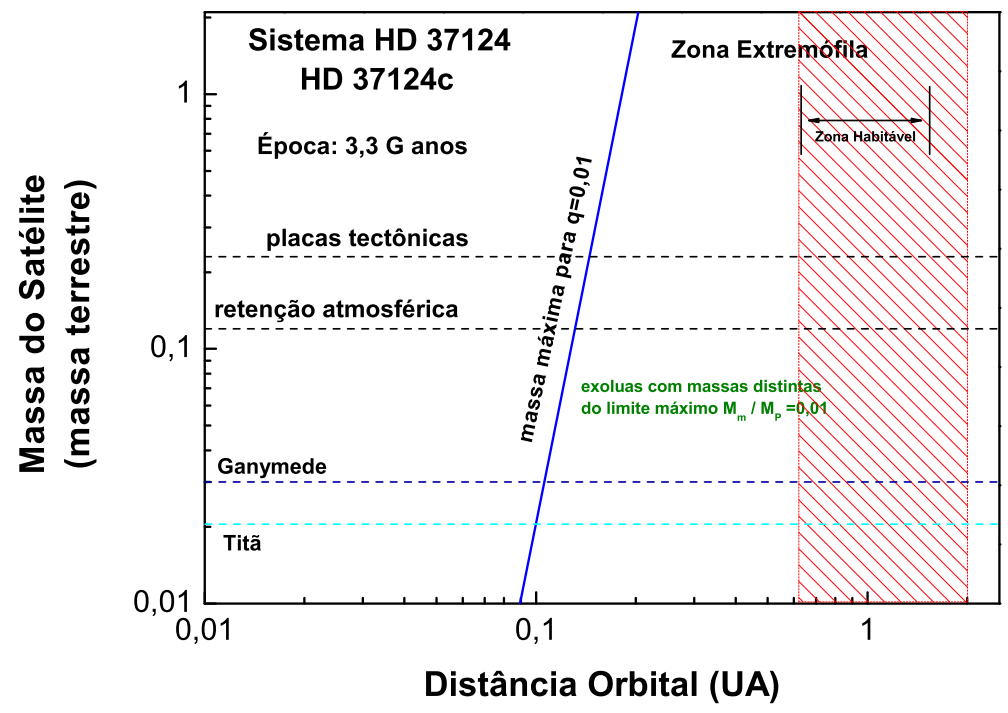

Figura 7.8: Satélites Habitáveis para o exoplaneta HD 37124c. A abscissa indica a distância orbital do planeta e, a ordenada, a massa de suas prováveis exoluas. A curva indica a massa máxima que as exoluas podem apresentar dentro do limite $q=0,01$. Acima desse limite é possível valores maiores ou menores que uma massa terrestre.

A tabela 7.3 apresenta as principais características do sistema. 
Tabela 7.3 - Habitabilidade para o Sistema Extrasolar HD 37124.

\begin{tabular}{cccccccc}
\hline \hline Planetas & Massa Estelar $\left(M_{\odot}\right)$ & $t_{s}($ a anos $)$ & $a_{p}(U A)$ & ZH $(U A)$ & ZE $(U A)$ & Satélites & $\mathrm{P}_{\text {hab }}$ (dias) \\
\hline \hline HD 37124b & 0,83 & $>10$ & 0,53 & - & - & - & - \\
\hline \hline HD 37124c & 0,83 & $>10$ & 1,71 & $0,63-1,54$ & $0,62-2,00$ & sim & $0,22-175$ \\
\hline \hline HD 37124d & 0,83 & $>10$ & 2,81 & - & - & - & - \\
\hline \hline
\end{tabular}

\subsection{Gliese $667 C c$, o melhor candidato a abrigar vida?}

Gliese $667 C$ é um sistema planetário localizado na Constelação do Escorpião que abriga dois planetas do tipo Super Terra. O objeto GJ 667Cc está localizado na Zona Habitável estelar e pode abrigar vida. Esse planeta apresenta massa aproximada de $4,5 M_{\oplus}$ e orbita a estrela GJ $667 C$, de tipo espectral M2V $\left(0,33 M_{\odot}\right)$.

A figura 7.9 apresenta as Zonas Habitável e Extremófila Contínuas (ZHC e ZEC) para o sistema planetário.

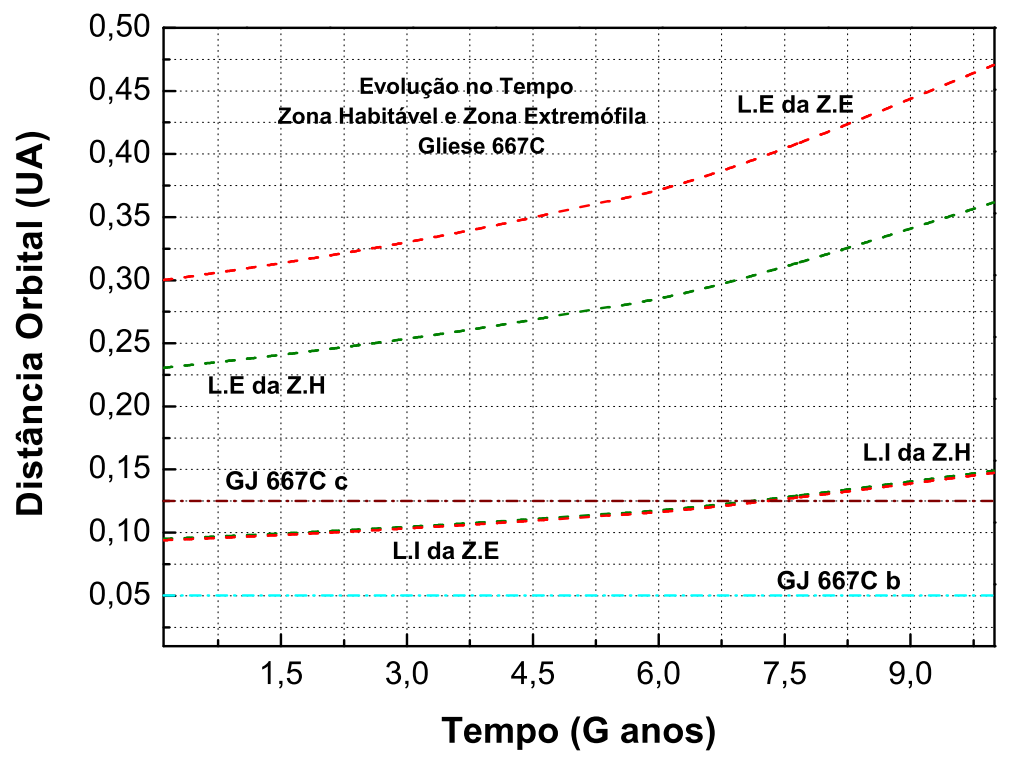

Figura 7.9: Zonas Habitável e Extremófila contínuas para o Sistema Extrasolar Gliese 667C. L.I e L.E são os limites interno e externo das Zonas Habitável (Z.H) e Extremófila (Z.E) do sistema.

Nota-se que o planeta permanece nas Zonas Habitável e Extremófila Contínuas até aproximadamente 7,0 bilhões de anos, lembrando que a idade do sistema é superior a 
2,0 bilhões de anos (http://exoplanet.eu/). A 7.10 (a) mostra que o planeta GJ 667Cc encontra-se na Zona Habitável estelar para valores de pressão parcial de $\mathrm{CO}_{2}$ bem menores que os apresentados pelo exoplaneta Gliese 581d, fazendo provavelmente dele o melhor candidato a abrigar vida entre os planetas descobertos até o momento. A figura 7.10 (b) apresenta a Zona Extremófila do sistema em função da pressão parcial de dióxido de carbono; o planeta em análise está em posições orbitais compatíveis com a definição de Zona Extremófila para amplos valores de tempo e pressão parcial de $\mathrm{CO}_{2}$. Entretanto, particularmente em cerca de 8,0 bilhões de anos, ele não satisfará tais requisitos.

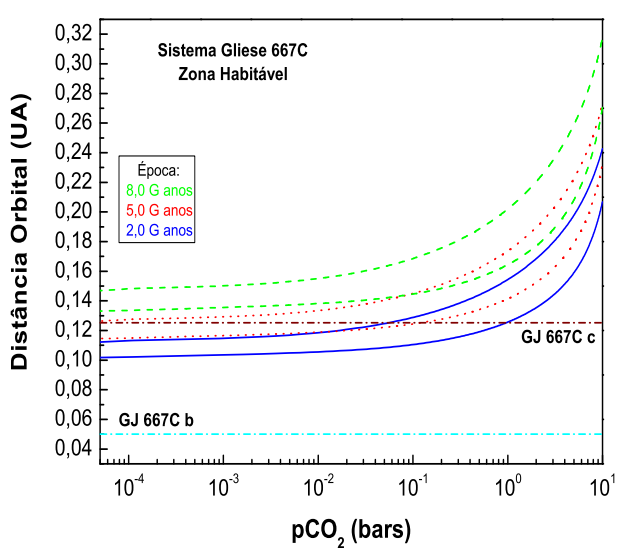

(a)

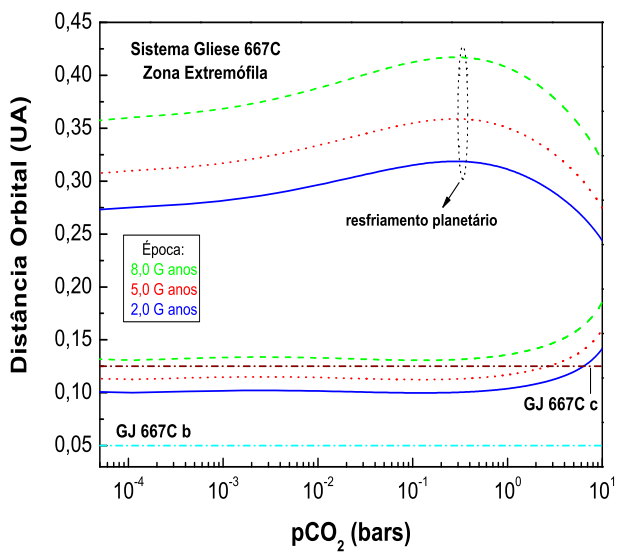

(b)

Figura 7.10: Análise das condições de habitabilidade para o Sistema Gliese $667 C$ : (a) e (b) mostram as Zonas Habitável e Extremófila em função da pressão de dióxido de carbono para o Sistema Gliese $667 C$ em períodos de tempo aproximados de 2,0,5,0 e 8,0 bilhões de anos respectivamente.

Repetindo a análise feita para os exoplanetas Gliese 581d e HD 37124c, pode-se determinar a possibilidade do exoplaneta abrigar um satélite com condições de habitabilidade suficientes para sustentar o desenvolvimento de alguma forma de vida em sua superfície.

A figura 7.11 apresenta essa análise para o planeta GJ 667Cc. Nota-se a impossibilidade desse planeta apresentar uma lua compatível com as condições otimizadas de habitabilidade; porém, assim como o exoplaneta Gliese 581d, ele pode sustentar um satélite natural apto a abrigar micro-organismos extremófilos. Utilizando valores de $Q_{p}=100$ e $Q_{p}=350$, verifica-se que a massa mínima para suas luas está abaixo dos valores do satélite natural de Saturno, Titã.

A observação das figuras 7.5 e 7.11 indica que há uma maior probabilidade de formação 
de satélites naturais massivos orbitando exoplanetas do tipo Super Terras mais afastados de suas estrelas hospedeiras. Assim, luas com caracterícas semelhantes a Titã, que orbitam estrelas do tipo $M$, devem ser procuradas em planetas cujas posições orbitais são maiores que 0,19UA, considerando válidos os valores de $Q_{p}$ entre 100 e 500 .

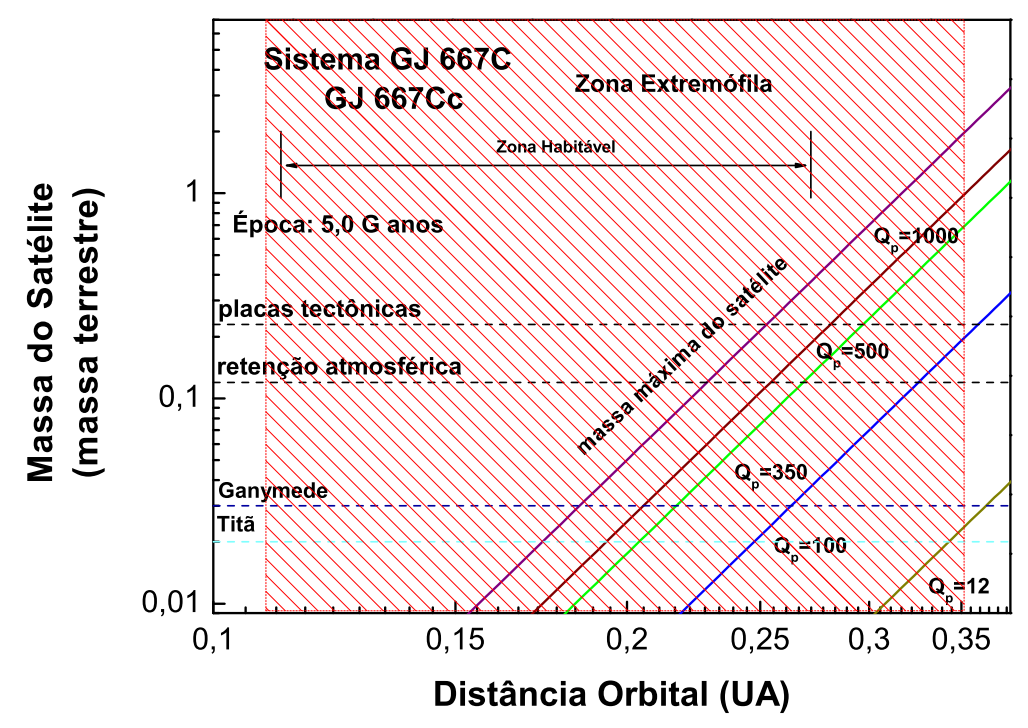

Figura 7.11: Satélites Habitáveis para o exoplaneta Gliese $667 C c$. A abscissa indica a distância orbital do planeta e, a ordenada, a massa de suas prováveis exoluas. As curvas indicam a massa máxima que as exoluas podem apresentar dentro do limite $q=0,01$.

A tabela 7.4 aponta as principais características do sistema.

Tabela 7.4 - Habitabilidade para o Sistema Gliese $667 C$.

\begin{tabular}{cccccccc}
\hline \hline Planetas & Massa Estelar $\left(M_{\odot}\right)$ & $t_{s}($ G anos $)$ & $a_{p}(U A)$ & ZH $(U A)$ & ZE $(U A)$ & Satélites & $\mathrm{P}_{\text {hab }}($ dias $)$ \\
\hline \hline GJ 667Cb & 0,33 & $>10$ & 0,05 & - & - & - & - \\
\hline \hline GJ 667Cc & 0,33 & $>10$ & 0,13 & $0,11-0,27$ & $0,10-0,35$ & sim & $0,30-5,87$ \\
\hline \hline
\end{tabular}

Como a idade do Sistema GJ 667C não é conhecida, apresentou-se na tabela 7.4 valores para a ZH e ZE referentes a 5, 0 bilhões de anos. 


\subsection{O Planeta HD $85512 b$ está realmente na Zona Habitável?}

O planeta HD $85512 b$, orbitando uma estrela de tipo K5V (0,69 $\left.M_{\odot}\right)$, localizada acerca de 36, 5 anos luz da Terra é uma Super Terra de massa aproximadamente igual a $3,5 M_{\oplus}$. Em agosto de 2011, esse planeta foi anunciado como sendo o candidato mais apto a abrigar vida entre os planetas descobertos até aquele momento, juntamente com o Gliese 581d (Kaltenegger, Udry e Pepe, 2011). Entretanto, ao ser submetido às condições impostas pelo modelo utilizado neste trabalho, o exoplaneta HD $85512 b$ não apresenta os requisitos mínimos para ser habitável, ou seja, sua posição orbital ao redor da estrela hospedeira é incompatível com as definições de Zonas Habitável ou Extremófila.

A figura 7.12 e a tabela 7.5 apresentam as características desse sistema extrasolar.

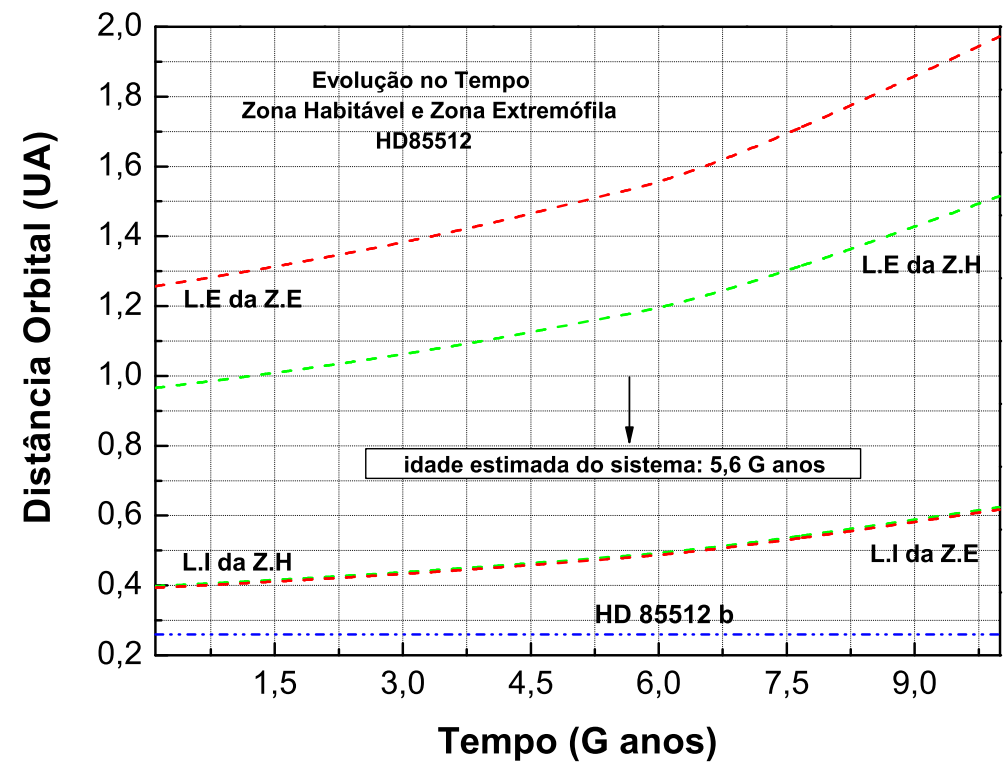

Figura 7.12: Zonas Habitável e Extremófila contínuas para o Sistema Extrasolar HD 85512b. L.I e L.E são os limites interno e externo das Zonas Habitável (Z.H) e Extremófila (Z.E) do sistema.

Tabela 7.5 - Habitabilidade para o Sistema HD 85512.

\begin{tabular}{cccccccc}
\hline \hline Planetas & Massa Estelar $\left(M_{\odot}\right)$ & $t_{s}($ G anos $)$ & $a_{p}(U A)$ & ZH $(U A)$ & ZE $(U A)$ & Satélites & P $_{\text {hab }}($ dias $)$ \\
\hline \hline HD 85512b & 0,69 & $>10$ & 0,26 & $0,48-1,17$ & $0,47-1,53$ & - & - \\
\hline \hline
\end{tabular}


Talvez os resultados discrepantes entre os dois modelos devam estar relacionados com o modo pelo qual se obteve a estimativa da temperatura do exoplaneta. O modelo proposto neste trabalho estimou a temperatura superficial média do planeta extrasolar HD $85512 b$. Já o modelo proposto por Kaltenegger et al. (2011) faz uma estimativa da temperatura de equilíbrio do planeta, considerando-o habitável caso esse parâmetro esteja no intervalo $175<T_{e q}<270 \mathrm{~K}$.

\subsection{Outros Sistemas Extrasolares podem abrigar vida extremófila?}

As análises de possíveis exoplanetas gigantes gasosos exibindo posições orbitais compatíveis com as definições de Zonas Habitável e Extremófila são apresentadas no apêndice C. O estudo do conjunto formado por esses planetas é importante porque seus satélites hipotéticos podem oferecer condições ideais para que a vida se desenvolva, mesmo que em sua vertente menos complexa, representada pelos micro-organismos extremófilos. 


\section{Capítulo 8}

\section{Conclusões}

A astrobiologia é um campo da ciência interdisciplinar e desafiador. A vida conhecida na Terra se desenvolve respeitando certos limites físico-químicos. Espera-se encontrar micro-organismos extremófilos em ambientes extraterrestres semelhantes aos terrestres, principalmente em habitats onde existam reservatórios de água. Para verificar essa possibilidade, calculou-se a região ao redor das estrelas onde este solvente pode ser encontrado (Zona Habitável (ZH) e Zona Extremófila(ZE)). Com essa finalidade, foi utilizado um modelo que simula uma atmosfera densa, composta principalmente por nitrogênio, água e dióxido de carbono, semelhante à terrestre.

Os sistemas extrasolares analisados podem abrigar planetas e luas no interior de suas Zonas Habitável e Extremófila. Porém, caso planetas hipotéticos similares à Terra estivessem localizados em distâncias orbitais semelhantes a dos planetas gigantes reais, a maioria manteria água líquida em sua superfície somente se apresentassem altas concentrações de dióxido de carbono em sua atmosfera. Assim, o modelo utilizado neste trabalho funcionou como um "filtro" na busca de posições orbitais onde exoplanetas podem ser potencialmente habitáveis.

A presença de exoluas orbitando exoplanetas gigantes foi simulada. Concluiu-se, que os planetas gigantes gasosos podem abrigar satélites naturais com ampla variedade de massa em distâncias orbitais compatíveis com as definições de Zonas Habitável e Extremófila: exoluas semelhantes a Europa, Titã e Terra. Entretanto, os dois planetas do tipo Super Terra analisados, GL 581d e GJ 667Cc, podem apenas ser orbitados por exoluas de baixa massa, análogas a Titã e Europa. Planetas localizados em distâncias orbitais maiores possuem grande probabilidade de abrigar satélites naturais massivos, o que talvez limite 
a existência de exoluas análogas à Terra orbitando planetas Super Terras em sistemas extrasolares com ZH e ZE próximas à estrela central (estrelas de baixa massa).

Estrelas do tipo M, orbitadas por exoplanetas do tipo Super Terras, localizados em distâncias orbitais próximas ou além do limite exterior da Zona Extremófila constituem um sistema apto a possuir satélites naturais com massa igual a 0,23 $M_{\oplus}$. Assim, caso exoplanetas como GJ 667Cc e GL 581d, estivessem localizados em distâncias orbitais de 0,29 $U A$ e 0,35UA, poderiam abrigar exoluas massivas o suficiente para reterem atmosfera e apresentarem atividades tectônicas por bilhões de anos dentro da Zona Extremófila, considerando valores de $Q_{p}=350$ e $Q_{p}=100$ respectivamente; nota-se que a imposição de um valor de $Q_{p}=100$ impossibilita que um provável satélite natural do planeta GJ 667Cc mantenha atividades tectônicas. Essas mesmas estrelas quando orbitadas por gigantes gasosos (ver Sistema GL 876) oferecem um cenário favorável à existência de exoluas, apresentando características otimizadas de habitabilidade: seus planetas gigantes são aptos a abrigarem exoluas dentro da Zona Habitável com condições geodinâmicas semelhantes a terrestre (massivas o suficiente para reterem um conteúdo atmosférico adequado e manterem atividades tectônicas ao longo de bilhões de anos).

Quando se analisa a possibilidade de satélites naturais abrigarem extremófilos terrestres, deve-se considerar ainda a possibilidade desses objetos celestes adquirirem energia de fontes distintas da solar. Nos capítulos 3 e 5, argumentou-se sobre o fenômeno de aquecimento através de forças de maré. Desse modo, exoluas orbitando planetas gigantes além da Zona Extremófila, similares às observadas no Sistema Solar, poderiam garantir a presença de micro-organismos extremófilos em suas superfícies (vide figura 6.3). A injeção de energia acontece graças à proximidade entre a lua e seu planeta hospedeiro gigante. Esse complexo sistema planeta-lua ainda pode receber material biológico via corpos externos como meteoritos, poeira interestelar, cometas ou até mesmo através de transferência direta de uma exolua a outra, de forma similar ao ocorrido entre Io e Europa.

A análise da região orbital estável ao qual uma exolua deve se encontrar para que não sofra perturbações estelar ou de seu planeta hospedeiro impõe um limite extra para a definição de habitabilidade (ver capítulo 6). Verificou-se que o período orbital da maioria das exoluas analisadas está dentro do limite ideal proposto por Dole (1964) para habitabilidade, ou seja, períodos entre $4 \leq P_{\text {exolua }}^{\text {est }} \leq 16$ dias. 
A extensão da região em torno das estrelas, onde a sobrevivência de micro-organismos extremófilos é possível, pode ajudar na tentativa de ratificar a teoria da panspermia. No capítulo 3, discutiu-se a possibilidade de sobrevivência de alguns micro-organismos expostos a condições espaciais severas em uma possível viagem interplanetária. Todavia, nos capítulos 1, 2, 5 e 6, foram debatidos temas relacionados à existência de compostos orgânicos no meio interestelar, ao bombardeamento planetário por corpos externos, aos processos de migração de planetas e luas, a possível transferência de material de Io para Europa, etc ... Há grandes possibilidades de que material orgânico e até mesmo microorganismos se desloquem no interior da Zona Extremófila. Consequentemente, o conceito de Zona Extremófila é mais um argumento posto em favor da ratificação da hipótese de que materiais orgânicos e até mesmo micro-organismos extraterrestres podem ter atingido a superfície da Terra, de exoplanetas e exoluas.

A conclusão do trabalho ratifica a possibilidade de existência de micro-organismos extremófilos na superfície de planetas/luas de sistemas extrasolares, assim como a transferência de diversos tipos de materiais (biológicos ou não) entre corpos que estejam localizados dentro da Zona Extremófila. O trabalho pode ser estendido com a finalidade de compreender os limites das Zonas Habitável e Extremófila para outros modelos atmosféricos, assim como considerando solventes distintos da água; pode-se ainda aumentar o limite máximo de temperatura para valores acima dos $370 \mathrm{~K}$. Outra questão importante a ser analisada é o papel real das propriedades do dióxido de carbono na formação de nuvens de $\mathrm{CO}_{2}$ e sua contribuição para o clima de planetas com composição atmosférica análoga a da Terra, tema que ainda segue em aberto. Há também a possibilidade de estudar o efeito da presença de uma exolua massiva o suficiente para alterar a velocidade de rotação de seu planeta hospedeiro. Também é de grande interesse a compreensão dos mecanismos de transferência de calor através da atmosfera, dos oceanos e da superfície, capazes de manter as condições de habitabilidade em planetas com apenas uma face voltada para sua estrela. As oportunidades de futuros estudos são enormes e desafiadoras. 


\section{Referências Bibliográficas}

ACUNA, M. H. et al.. Magnetic Field and Plasma Observations at Mars: Initial Results of, Science, v. 279, p. 1676, 1998.

AGNOR, C. B., HAMILTON, D. P.. Neptune's capture of its moon Triton in a binary-planet gravitational encounter, Nature, v. 441, p. 192-194. 2006.

AGNOR, C. B. et al.. On the Character and Consequences of Large Impacts in the Late Stage of Terrestrial Planet Formation, Icarus, v.142, p. 219-237, 1999.

ALlÈGRE, C. J., MANHÈS, G., GÖPEL, C.. The age of the Earth, Geochim. Cosmochim. Acta, v. 59, p. 1445-1456, 1995.

ALVARELLOS, J. L. et al.. Transfer of mass from Io to Europa and beyond due to cometary impacts, Icarus, v. 194, p. 636-646, 2008.

ANDERSON, J. D.. Europa's Differentiated Internal Structure: Inferences from Four Galileo Encounters, Science, v. 281, p. 2019, 1998.

ARRHENIUS, S. A.. On the Influence of Carbonic Acid in the Air upon the Temperature of the Ground, Philosophical Magazine and Journal of Science, v. 41, p. 237-276, 1896.

ARRHENIUS, S. A., BORNS, H.. Worlds in the making; the evolution of the universe, New York and London: Harper brothers, 1908.

ARTYMOWICZ, P.. Dynamics of Gaseous Disks with Planets, in: CAROFF, L. et al.. Debris disks and the formation of planets, Astronomical Society of the Pacific Conference Series, v. 324, p. 39, 2004.

ASPLUnD, M. et al.. The Solar Chemical Composition, in: BARNES, T. G., III, BASH, F. N.. Cosmic abundances as records of stellar evolution and nucleosynthesis, Astronomical Society of the Pacific Conference Series, v. 336, p. 25, 2005. 
ATOBE, K., IDA, S.. Obliquity evolution of extrasolar terrestrial planets, Icarus, v. 188, p. 1-17, 2007.

BARNES, R. et al. . Tidal Limits to Planetary Habitability, ApJ, v. 700, p. L30-L33, 2009 .

BARNES, R. et al.. Tides and the Evolution of Planetary Habitability, Astrobiology, v. 8, p. 557-568, 2008.

BARNES, J. W., O'BRIEN, D. P.. Stability of Satellites around Close-in Extrasolar Giant Planets, ApJ, v. 575, p. 1087-1093. 2002.

BAROSS, J. A., DEMING, J. W.. Possible artefactual basis for apparent bacterial growth at $250{ }^{\circ} \mathrm{C}$, Nature, v. 307, p. 423-426, 1984.

BARUCCI, M. A., et al.. Is Sedna another Triton?, A\&A, v. 439, p. L1-L4, 2005.

BATTISTA, J. R.. Against all odds: the survival strategies of Deinococcus radiodurans, Annu. Rev. Microbiol., v. 51, p. 203-224, 1997.

BENNER, R. A.. Phanerozoic Atmospheric Oxygen, Annual Review of Earth and Planetary Sciences, v. 31, p. 105-134, 2003.

BECKWITH, S. V. W., SARGENT, A. I.. The occurrence and properties of disks around young stars, in: LEVY, E. H., LUNINE, J. I., Protostars and planets iii, 521-541, 1993.

BENNER, S. A., KIM, H.-J.. Titan, Weird Chemistry, and Weird Life, LPI Contributions, v. 1538, p. 5097, 2010.

BENNER, R. A.. Phanerozoic Atmospheric Oxygen, Annual Review of Earth and Planetary Sciences, v. 31, p. 105-134, 2003.

BERNHARDT, G. et al.. Biomolecules are unstable under "black smoker" conditions, Naturwissenschaften, v. 71, p. 583-586, 1984.

BINNEY, J., Tremaine, S.. Galactic dynamics, 1987.

BLANEY, D. L. et al.. Volcanic eruptions on Io: Heat flow, resurfacing, and lava composition, Icarus, v. 113, p. 220-225, 1995.

BLITZ, L., Giant molecular clouds, in: LEVY, E. H., LUNINE, J. I.. Protostars and planets iii, p. 125-161, 1993.

BLÖCHL, Elisabeth, et al.,. Pyrolobus fumarii, gen. and sp. nov., represents a novel group of archaea, extending the upper temperature limit for life to $113^{\circ} \mathrm{c}$, Extremophiles, 
v.1, p. 14-21, 1997.

BODENHEIMER, P., HUBICKYJ, O., LiSSAUER, J. J.. Models of the in Situ Formation of Detected Extrasolar Giant Planets, Icarus, v. 143, p. 2-14 2000.

BRICEÑO, C. et al.. The CIDA-QUEST Large-Scale Survey of Orion OB1: Evidence for Rapid Disk Dissipation in a Dispersed Stellar Population, Science, v. 291, p. 93-97, 2001.

BROWN, L. L., KASTING, J. F.. A carbon dioxide/methane greenhouse atmosphere on early Mars, in: SQUYRES, S., KASTING, J.. Early mars: How warm and how wet?, 1993.

BUCKER, H., HORNECK, G.. The biological effectiveness of HZE-particles of cosmic radiation studied in the Apollo 16 and 17 Biostack experiments, Acta Astronautica, v. 2, p. 247-264, 1975.

BUHL, D.. Chemical Constituents of Interstellar Clouds, Nature, v. 234, p. 332-334, 1971.

BURROWS, A. et al.. A Nongray Theory of Extrasolar Giant Planets and Brown Dwarfs, ApJ, v. 491, p. 856, 1997.

CAMERON, A. G. W.. Formation of the Outer Planets (Article published in the Space Science Reviews special issue on 'Outer Solar System Exploration - An Overview', ed. by J. E. Long and D. G. Rea.), Space Sci. Rev., v. 14, p. 383-391, 1973.

CAMERON, A. G. W.. The Early Evolution of the Solar System, NASA Special Publication, v. 319, p. 347, 1973.

CANO, R. J., BORUCKI, M. K.. Revival and Identification of Bacterial Spores in 25to 40-Million-Year-Old Dominican Amber, Science, v. 268, p. 1060-1064, 1995.

CANUP, R. M., WARD, W. R.. A common mass scaling for satellite systems of gaseous planets, Nature, v. 441, p. 834-839, 2006.

CANUP, R. M., ASPHAUG, E.. An impact origin of the Earth-Moon system, AGU Fall Meeting Abstracts, A2, 2001.

CAVICCHIOLI, R., Extremophiles and the Search for Extraterrestrial Life, Astrobiology, v. 2, p. 281-292, 2002.

CHABRIER, G., et al.. Evolutionary Models for Very Low-Mass Stars and Brown Dwarfs with Dusty Atmospheres, ApJ, v. 542, p. 464-472, 2000. 
CHAPELLE, F. H. et al.. A hydrogen-based subsurface microbial community dominated by methanogens, Nature, v. 415, p. 312-315, 2002.

CHYBA, C. F.. Impact delivery and erosion of planetary oceans in the early inner solar system, Nature, v. 343, p. 129-133, 1990.

CHYBA, C. F.. The cometary contribution to the oceans of primitive earth, Nature, v. 330, p. 632-635, 1987.

COX , M. M., BATTISTA, J. R.. Deinococcus radiodurans - the consummate survivor, Nature Reviews Microbiology, v. 3, p. 882-892, 2005.

DANIELSON, R. E. et al.. An Inversion in the Atmosphere of Titan, Icarus, v. 20, p. 437, 1973.

DELONG, E. F., et al.. High abundance of Archaea in Antarctic marine picoplankton, Nature, v. 371, p. 695-697, 1994.

DENK, T. et al.. Europa's Colors, Observed by Galileo-SSI: Yellow Mottled Terrain on the Leading Side, Brown Mottled Terrain on the Trailing Side, Lunar and planetary institute science conference abstracts, Lunar and Planetary Inst. Technical Report, v. 29, p. 1684,1998 .

DE PATER, I., LISSAUER, J. J.. Planetary Sciences, 2001.

DES ETANGS, A. L. A diagram to determine the evaporation status of extrasolar planets, Astronomy Astrophysics, v. 461, p. 1185-1193, 2007.

DOLE, S. H., Habitable planets for man, 1964.

DOMINGOS, R. C. et al.. Stable satellites around extrasolar giant planets, MNRAS, v. 373, p. 1227-1234, 2006.

DRIESSEN, Arnold J. M. et al.. Membrane composition and ion-permeability in extremophiles, Fems Microbiology Reviews, v. 18, p. 139-148, 1996.

DUTREY, A. et al.. Chemistry of protosolar-like nebulae: The molecular content of the DM Tau and GG Tau disks., A\&A, v. 317, p. L55-L58, 1997.

EDGEWORTH, K. E.. The evolution of our planetary system, Journal of the British Astronomical Association, v. 53, p. 181-188, 1943.

EDWARDS, K. J.. An Archaeal Iron-Oxidizing Extreme Acidophile Important in Acid Mine Drainage, Science, v. 287, p. 1796-1799, 2000.

EMERY, J. P., et al.. Ices on (9037r) Sedna: confirmation and compositional cons- 
traints, A\&A, v. 466, p. 395-398 2007.

FARQUHAR, J. et al.. Atmospheric Influence of Earth's Earliest Sulfur Cycle, Science, v. 289 , p. $756-759,2000$.

FIGUEREDO, P. H., GREELEY, R.. Resurfacing history of Europa from pole-to-pole geologimapping, Icarus, v. 167, p. 287-312, 2004.

FISCHER, D. et al.. Spectral Analysis of Stars on Planet-Search Surveys, in: DUPREE,

A. K., BENZ, A. O.. IAU Symposium, Stars as suns : Activity, evolution and planets, v. 219, p. 29, 2004.

FISHER, C. R. et al.. Methane Ice Worms: Hesiocaeca methanicola Colonizing Fossil Fuel Reserves, Naturwissenschaften, v. 87, p. 184-187, 2000.

FOGG, M. J.. An Estimate of the Prevalence of Biocompatible and Habitable Planets, Journal of the British Interplanetary Society, v. 45, p. 3-12, 1992.

FORGET, F., PIERREHUMBERT, R. T.. Warming Early Mars with Carbon Dioxide Clouds That Scatter Infrared Radiation, Science, v. 278, p. 1273, 1997.

FORTES, A. D.. Exobiological Implications of a Possible Ammonia-Water Ocean inside Titan, Icarus, v. 146, p. 444-452, 1997.

FRANCIS, P. W., WOOD, C. A.. Absence of silicic volcanism on Mars - Implications for crustal composition and volatile abundance, J. Geophys. Res., v. 87, p. 9881-9889, 1982.

FRANCK, S. et al.. Planetary habitability: is Earth commonplace in the Milky Way? Naturwissenschaften, v. 88, p. 416-426, 2001.

FRANCK, S. et al.. Limits of photosynthesis in extrasolar planetary systems for earth-like planets, Advances in Space Research, v. 28, p. 695-700, 2001.

FRANCK, S. et al.. Habitable zone for Earth-like planets in the solar system, Planet. Space Sci., v. 48, p. 1099-1105, 2000.

FRESSIN, F. et al.. Interpreting and predicting the yield of transit surveys: giant planets in the OGLE fields, A\&A, v. 475, p.729-746, 2007.

FRESSIN, F. et al.. A STEP: Towards a Large Photometric Survey for Exoplanets at Dome C, in: EPCHTEIN, N., CANDIDI, M.. EAS Publications Series, v. 25, p. 225-232, 2007.

GOLD, T.. The Deep, Hot Biosphere, Proceedings of the National Academy of Science, 
v. 89, p. 6045-6049, 1992.

GOLDREIC, P., TREMAINE, S.. Disk-satellite interactions, ApJ, v. 241, p. 425-441, 1980

GOLDREIC, P., TREMAINE, S.. The excitation of density waves at the Lindblad and corotation resonances by an external potential, ApJ, v. 233, p. 857-871, 1979.

GOUGH, D. O.. Solar interior structure and luminosity variations, Solar Physics, v. 74, p. 21-34, 1981.

GREVESSE, N. et al.. The New Solar Chemical Composition, Eas Publications Series, v. 17 , p. 21-30, 2005 .

GRIEßMEIER, J.-M. et al.. Cosmic Ray Impact on Extrasolar Earth-Like Planets in Close-in Habitable Zones, Astrobiology, v. 5, p. 587-603, 2005.

GRIFFITH, C. A., ZAHNLE, K.. Influx of cometary volatiles to planetary moons: The atmospheres of 1000 possible Titans, J. Geophys. Res., v. 100, p. 16907-16922, 1995.

GROUT, B. Biophysics and biochemistry at low temperatures By Felix Franks. , Endeavour, v. 10, p. 210, 1986.

GUEDEL, M. et al.. The X-Ray Sun in Time: A Study of the Long-Term Evolution of Coronae of Solar-Type Stars, ApJ, v. 483, p. 947, 1997.

GUERRIER-TAKADA, C. et al.. The RNA moiety of ribonuclease $P$ is the catalytic subunit of the enzyme, Cell, v. 35, p. 849-857, 1983.

HABERLE, R. M. et al.. A model for the evolution of CO2 on Mars, Icarus, v. 109, p. 102-120, 1994.

HAISCH, K. E., Jr., LADA, E. A., LADA, C. J.. Disk Frequencies and Lifetimes in Young Clusters, ApJ, v. 553, p. L153-L156, 2001.

HALBWACHS, J. L., MAYOR, M., UDRY, S.. Statistical properties of exoplanets. IV. The period-eccentricity relations of exoplanets and of binary stars, A\&A, v. 431, p. 1129-1137, 2005.

HART, M. H., The Effect of a Planet's Size on the Evolution of its Atmosphere, Bulletin of the american astronomical society, v. 10, p. 554, 1978.

HART, M. H.. The evolution of the atmosphere of the earth, Icarus, v. 33, p. 23-39, 1978 .

HARTMANN, W. K., DAVIS, D. R.. Satellite-sized planetesimals and lunar origin, 
Icarus, v. 24, p. 504-514, 1975.

HEATH, M., The Forest-Habitability Of Earthlike Planets, in: DOYLE, L. R., Circumstellar habitable zones, p. 445, 1996.

HERBERT, R.A., SHARP, R.J.. Molecular biology and biotechnology of extremophiles, Blackie, p. 3311992.

HOLLENBACH, D. J. et al., in Protostars and Planets IV, 2000.

HOOVER, R. B. et al.. Astrobiology of comets, in: HOOVER, R. B., LEVIN,

G. V., ROZANOV, A. Y. Society of Photo-Optical Instrumentation Engineers (SPIE) Conference Series, v. 5555, p. 93-106, 2004.

HORIKAWA, D. D. et al.. Radiation tolerance in water bears, 36th cospar scientific assembly, COSPAR Meeting, v. 36, p. 2303, 2006.

HORNECK, G. et al.. Biological dosimetry of solar radiation for different simulated ozone column thicknesses, Journal of Photochemistry and Photobiology B-biology, v. 32, p. 189-196, 1996.

HORNECK, G et al.. Long-term survival of bacterial spores in space, Advances in Space Research, v. 14, p. 41-45, 1994.

HORNECK, GERDA. Responses of Bacillus subtilis spores to space environment: Results from experiments in space, Origins of Life and Evolution of Biospheres, v. 23, p. 37-52, 1993.

HORNECK, G, Radiobiological experiments in space: A review, International Journal of Radiation Applications and Instrumentation. Part D. Nuclear Tracks and Radiation Measurements, v. 20, p. 185-205, 1992.

HOYLE, F., WICKRAMASINGHE, N. C.. Organic grains in space, Astrophysics and Space Science, v. 69, p. 511-513, 1980.

HUANG, S.-S.. Life Outside the Solar System, Scientific American, v. 202, p. 55-63, 1960.

HUANG, S.-S., The Limiting Sizes of the Habitable Planets, 1960.

HUANG, S.-S., The Problem of Life in the Universe and the Mode of Star Formation, PASP, v. 71, p. 421, 1959.

IP, W.-H., FERNANDES, J. A.. Exchange of condensed matter among the outer and terrestrial protoplanets and the effect on surface impact and atmospheric accretion, 
Icarus, v. 74, p. 47-61, 1998.

JACOB, R A, BURRI, B J. Oxidative damage and defense, Am J Clin Nutr, v. 63, n. 6, p. 990, 1996.

JANOT-PACHECO, E. et al.. Exoplanet environments to harbour extremophile life, in: Proceedings of The International Astronomical Union, v. 5, 2009.

JOSHI, M. M. et al.. Simulations of the Atmospheres of Synchronously Rotating Terrestrial Planets Orbiting M Dwarfs: Conditions for Atmospheric Collapse and the Implications for Habitability, Icarus, v. 129, p. 450-465, 1997.

JÖNSSON, INGEMAR et al.. Tardigrades survive exposure to space in low earth orbit, Curr Biol, v. 18, n. 17, p. R729-R731, 2008.

KALTENEGGER, L., UDRY, S., PEPE, F., A Habitable Planet around HD 85512?, ArXiv e-prints, 2011.

KASHEFI, KAZEM, LOVLEY, DEREK R.. Extending the Upper Temperature Limit for Life, Science, v. 301, p. 934-934, 2003.

KASting, J. F., CATling, D.. Evolution of a Habitable Planet, ARA\&A, v. 41, p. 429-463, 2003.

KASTING, J.. Habitable Zones Around Stars and the Search for Extraterrestrial Life, American astronomical society meeting abstracts, Bulletin of the American Astronomical Society, v. 30, p. 1328, 1998.

KASTING, J. F.. Habitability of Planets, in: DEVINCENZI, D., BRIGGS, G., and et al.. Astrobiology workshop: Leadership in astrobiology, p.10, 1996.

KASTING, J. F. et al.. Habitable Zones around Main Sequence Stars, Icarus, v. 101, p. 108-128, 1993 .

KASTING, J. F.. Earth's early atmosphere, Science, v. 259, p. 920-926, 1993.

KASTING, J. F.. CO2 condensation and the climate of early Mars, Icarus, v. 94, p. $1-13,1991$.

KASTING, J. F. et al.. How climate evolved on the terrestrial planets, Scientific American, v. 258, p. 46-53, 1988.

KASTING, J. F., POLLACK, J. B.. Loss of water from Venus. I - Hydrodynamic escape of hydrogen, Icarus, v. 53, p. 479-508, 1983.

KELLER, MARTIN, et al.. Thermococcus alcaliphilus sp. nov., a new hyperthermophilic 
archaeum growing on polysulfide at alkaline $p H$, Archives of Microbiology, v. 164, p. 390-395, 1995.

KENNEDY, MAX J. et al.. Preservation records of micro-organisms: evidence of the tenacity of life, Microbiology-sgm, v. 140, p. 2513-2529, 1994.

KENYON, S. J., HARTMANN, L.. Spectral energy distributions of T Tauri stars Disk flaring and limits on accretion, ApJ, v. 323, p. 714-733, 1987.

KIM, Y.-C. et al., The $Y^{2}$ Isochrones for $\alpha$-Element Enhanced Mixtures ApJS, v. 143, p. 499-511, 2002.

KIPPENHAHN, R., WEIGERT, A., Stellar Structure and Evolution, 1990.

KRASNOPOLSKY, V. A., MAILlaRD, J. P., OWEN, T. C.. Detection of methane in the martian atmosphere: evidence for life?, Icarus, v. 172, p. 537-547, 2004.

KRUGER, K. et al.. Self-splicing RNA: Autoexcision and autocyclization of the ribosomal RNA intervening sequence of tetrahymena, Cell, v. 31, p. 147-157, 1982.

LAMMER, H. et al.. Atmospheric Escape and Evolution of Terrestrial Planets and Satellites, Space Sci. Rev., v. 139, p. 399-436, 2008.

LAMMER, H. et al.. Stellar-Planetary Relations: Atmospheric Stability as a Prerequisite for Planetary Habitability, in: DVORAK, R., FERRAZ-MELLO, S., A comparison of the dynamical evolution of planetary systems, p. 273, 2005.

LAMMER, H. et al.. Loss of water from Mars, Icarus, v. 165, p. 9-25, 2003.

LASKAR, J. et al.. Stabilization of the earth's obliquity by the moon, Nature, v. 361, p. $615-617,1993$.

LÉGER, A. et al.. A new family of planets? "Ocean-Planets", Icarus, v. 169, p. 499-504, 2004.

L'HARIDON, S. et al.. Hot subterranean biosphere in a continental oil reservoir, Nature, v. 377, p. 223-224, 1995.

LIN, D. N. C., PAPALOIZOU, J. C. B.. On the tidal interaction between protostellar disks and companions, in: LEVY, E. H., LUNINE, J. I.. Protostars and planets iii, 749-835, 1993.

LIN, D. N. C., PAPALOIZOU, J.. On the tidal interaction between protoplanets and the protoplanetary disk. III - Orbital migration of protoplanets, ApJ, v. 309, p. 846-857, 1986. 
LIN, D. N. C., PAPALOIZOU, J.. Tidal torques on accretion discs in binary systems with extreme mass ratios, MNRAS, v. 186, p. 799-812, 1979.

LINDAL, G. F. et al.. The atmosphere of Titan - an analysis of the Voyager 1 radio occultation measurements, Icarus, v. 53, p. 348-363, 1983.

LINDAHL, TOMAS, Instability and decay of the primary structure of DNA, Nature, v. 362, p. 709-715, 1993.

LINEWEAVER, C. H. et al.. The Galactic Habitable Zone and the Age Distribution of Complex Life in the Milky Way, Science, v. 303, p. 59-62, 2004.

LISSAUER, J. J.. Planet formation, ARA\&A, v. 31, p. 129-174, 1993.

LIOU, K. N. . An Introduction to Atmospheric Radiation, Academic Press, 2002.

LUNINE, J. I. et al.. Dynamical Models of Terrestrial Planet Formation Advanced Science Letters, v. 4, p. 325-338, 2011.

MACIEL, W. J.. Introdução à Estrutura e Evolução Estelar, São Paulo, Edusp, 1999.

MCKAY, D. S. et al.. Search for Past Life on Mars: Possible Relic Biogenic Activity in Martian Meteorite ALH84001, Science, v. 273, p. 924-930, 1996.

MADIGA, M. T. et al.. Biology of microorganisms, Pearson, 2012.

MALHOTRA, R.. On the delivery of planetesimals to a protoplanet in the solar nebula, Lunar and planetary institute science conference abstracts, Lunar and Planetary Inst. Technical Report, v. 24, p. 925-926, 1993.

MARAIS, DAVID J. DES. et al.. Remote Sensing of Planetary Properties and Biosignatures on Extrasolar Terrestrial Planets, Astrobiology, v. 2, p. 153-181, 2002.

MARCY, G. et al.. Observed Properties of Exoplanets: Masses, Orbits, and Metallicities, Progress of Theoretical Physics Supplement, v. 158, p. 24-42, 2005.

MARCY, G. W. et al.. Five New Extrasolar Planets, ApJ, v. 619, p. 570-584, 2005.

MARCY, G. W., BUTLER, R. P.. Doppler Detection of Extra-Solar Planets, in : DONAHUE, R. A., BOOKBINDER, J. A.. Cool stars, stellar systems, and the sun, Astronomical Society of the Pacific Conference Series, v. 154, p. 9, 1998.

MARGUET, EVELYNE, FORTERRE, PATRICK. DNA stability at temperatures typical for hyperthermophiles, Nucleic Acids Research, v. 22, p. 1681-1686, 1994.

MARION, G. M. et al.. The Search for Life on Europa: Limiting Environmental Factors, Potential Habitats, and Earth Analogues, Astrobiology, v. 3, p. 785-811, 2003. 
MARLEY, M. et al.. Model Visible and Near-infrared Spectra of Extrasolar Giant

Planets, American astronomical society meeting abstracts, Bulletin of the American Astronomical Society, v. 29, p. 1254, 1997.

MASSET, F. S.. PAPALOIZOU, J. C. B., Runaway Migration and the Formation of Hot Jupiters, ApJ, v. 588, p. 494-508, 2003.

MAYOR, M. et al.. The CORALIE survey for extrasolar planets. XII , VizieR Online Data Catalog, v. 341, p. 50391, 2004.

MAYOR, M., QUELOZ, D.. A Jupiter-mass companion to a solar-type star, Nature, v. 378, p. 355-359, 1995.

MCCORD, T. B., SOTIN, C.. Ceres: Evolution and current state, Journal of Geophysical Research (Planets), v. 110, p. 5009, 2005.

MCEWEN, A. S. et al.. The lithosphere and surface of Io, in: BAGENAL, F., DOWLING, T. E., MCKINNON, W. B.. Jupiter. the planet, satellites and magnetosphere, p. 307-328, 2004.

MISCHNA, M. A. et al.. Influence of carbon dioxide clouds on early martian climate, Icarus, p. 145, v. 546-554, 2000.

MOJZSIS, S. J. et al.. Evidence for life on Earth before 3,800 million years ago, Nature, v. 384, p. 55-59, 1996.

MURRAY, C. D., DERMOTT, S. F., Solar System Dynamics, 2000.

MURRAY, C. D., DERMOTT, S. F., Solar system dynamics, 1999.

MURRAY, N. et al.. Migrating Planets, Science, v. 279, p. 69, 1998.

MUZEROLLE, J. et al.. Disk Accretion at 10 Myr: Results from the TW Hydrae Association, in: JAYAWARDHANA, R., GREENE, T., Young stars near earth: Progress and prospects, Astronomical Society of the Pacific Conference Series, v. 244, p. 245, 2001.

NAMOUNI, F., The Fate of Moons of Close-in Giant Exoplanets, ApJ, v. 719, p. L145-L147, 2010.

NIEMANN, H. B. et al.. The abundances of constituents of Titan's atmosphere from the GCMS instrument on the Huygens probe, Nature, v. 438, p. 779-784, 2005.

OLLIVIER, M. et al.. Planetary Systems. Detection, Formation and Habitability of Extrasolar Planets., 2009. 
OORT, J. H.. The structure of the cloud of comets surrounding the Solar System and a hypothesis concerning its origin Bull. Astron. Inst. Netherlands, v. 11, p. 91-110, 1950. OWEN, T. C. et al.. Surface ices and the atmospheric composition of Pluto, Science, v. 261, p. 745-748, 1993.

PADMANABHAN, T.. Theoretical Astrophysics - Volume 2, Stars and Stellar Systems, 2001.

PAPALOIZOU, J. C. B., TERQUEM, CAROLINE. Planet formation and migration, Reports on Progress in Physics, v.69, p. 119-180, 2006

PAPAloizoU, J. C. B., TERQUem, C., NELSON, R. P.. Discs and Planetary Formation, in : SELLWOOD, J. A., GOODMAN, J., Astrophysical discs - an ec summer school, Astronomical Society of the Pacific Conference Series, v. 160, p. 186, 1999.

PAPALOIZOU, J., LIN, D. N. C.. On the tidal interaction between protoplanets and the primordial solar nebula. I - Linear calculation of the role of angular momentum exchange, ApJ, v. 285, p. 818-834, 1984.

PARKES, R. J. et al.. Deep bacterial biosphere in Pacific Ocean sediments, Nature, v. 371, p. 410-413, 1994.

PAULINO-LIMA, I. G. et al.. Survival of Deinococcus radiodurans Against LaboratorySimulated Solar Wind Charged Particles, Astrobiology, v. 11, p. 875-882, 2011.

PAULINO-LIMA, I. G. et al.. Laboratory simulation of interplanetary ultraviolet radiation (broad spectrum) and its effects on Deinococcus radiodurans, Planet. Space Sci., v. 58, p. $1180-1187,2010$.

PEALE, S. J. et al.. Tidal dissipation, orbital evolution, and the nature of Saturn's inner satellites, Icarus, v. 43, p. 65-72, 1980.

PEALE, S. J.. Consequences and inferences from tidal interactions in the solar system, Annales de Geophysique, v. 33, p. 23-29, 1977.

PEDERSEN, K.. Microbial life in deep granitic rock, Fems Microbiology Reviews, v. 20, p. 399-414, 2006.

PHILliPS, C. B., CHYBA, C. F.. Europa: Prospects for an Ocean and Life, in: CHELA-FLORES, J., OWEN, T., RAULIN, F., First steps in the origin of life in the universe, p. 25, 2001. 
PIKUTA, ELENA V. et al.. Microbial Extremophiles at the Limits of Life, Critical Reviews in Microbiology, v. 33, p. 183-209, 2007.

PORCO, C. C. et al.. Cassini Observes the Active South Pole of Enceladus, Science, v. 311, p. 1393-1401, 2006.

PRICE, P. B., SOWERS, T.. Temperature dependence of metabolic rates for microbial growth, maintenance, and survival, Proceedings of the National Academy of Science, v. 101, p. 4631-4636, 2004. PRINN, R. G., FEGLEY, B., Jr.. Kinetic inhibition of CO and N2 reduction in circumplanetary nebulae - Implications for satellite composition, ApJ, v. 249, p. 308-317, 1981.

RASIO, F. A., FORD, E. B.. Dynamical instabilities and the formation of extrasolar planetary systems, Science, v. 274, p. 954-956, 1996.

RASOOL, S. I., DE BERGH, C.. The Runaway Greenhouse and the Accumulation of $\mathrm{CO}_{2}$ in the Venus Atmosphere, Nature, v. 226, p. 1037-1039, 1970.

RAULIN, F.. Astrobiology and habitability of Titan, Space Sci. Rev., v. 135, p. 37-48, 2008.

RAULIN, F. et al.. New exo/astrobiological aspects of Titan 37th cospar scientific assembly, COSPAR Meeting, v. 37, p. 2567, 2008.

RAULIN, F., Exo-Astrobiological Aspects of Europa and Titan: From Observations to Speculations. Space Sci. Rev., v. 116, p. 471-487, 2005.

RAYMOND, S. N. et al.. Predicting Planets in Known Extrasolar Planetary Systems. III. Forming Terrestrial Planets, ApJ, v. 644, p. 1223-1231, 2006.

REGENAUER-LIEB, K. et al.. The Initiation of Subduction: Criticality by Addition of Water?, Science, v. 294, p. 578-581, 2001.

RIBAS, I. et al.. Evolution of the Solar Activity over Time and Effects on Planetary Atmospheres. I. High-Energy Irradiances (1-1700 A), ApJ, v. 622, p. 680-694, 2005.

RIVKIN, A. S., VOLQUARDSEN, E. L., CLARK, B. E.. The surface composition of Ceres: Discovery of carbonates and iron-rich clays, Icarus, v. 185, p. 563-567, 2006.

ROBERT, F.. Solar System Deuterium/Hydrogen Ratio, in:, LAURETTA, D. S., MCSWEEN, H. Y., Meteorites and the early solar system ii, p. 341-351, 2006.

ROBERT, F.. The D/H Ratio in Chondrites, Space Sci. Rev., v. 106, p. 87-101, 2003. ROTHSCHILD, L. J., MANCINELLI, R. L.. Life in extreme environments, Nature, v. 
409, p. 1092-1101 2001.

ROTHSCHILD, L. J.. Earth analogs for Martian life. Microbes in evaporites, a new model system for life on Mars, Icarus, v. 88, p. 246-260 1990.

RUSSELL, N. J.. Physiology and molecular biology of psychrophilic micro-organisms, 1992.

SAFRONOV, V. S.. Evolution of the protoplanetary cloud and formation of the earth and planets, 1972.

SANTOS, N. C. et al.. Statistical properties of exoplanets. II. Metallicity, orbital parameters, and space velocities, A\&A, v. 398, p. 363-376, 2003.

SCHARF, C. A.. The Potential for Tidally Heated Icy and Temperate Moons around Exoplanets, ApJ, v. 648, p. 1196-1205, 2006.

SCHLEPER, C. et al.. Life at extremely low pH, Nature, v. 375, p. 741-742, 1995.

SEKI, KUNIHIRO, TOYOSHIMA, MASATO. Preserving tardigrades under pressure, Nature, v. 395, n. 6705, p. 853-854, 1998.

SHARMA, A. et al.. Microbial Activity at Gigapascal Pressures, Science, v. 295, p. 1514-1517, 2002.

SHIZGAL, B. D., ARKOS, G. G.. Nonthermal escape of the atmospheres of Venus, Earth, and Mars, Reviews of Geophysics, v. 34, p. 483-505, 1996.

SLEEP, N. H. et al.. Large Impacts and the Survival of Ecosystems on the Early Earth, LPI Contributions, v. 681, p. 85, 1988.

SMITH, M.D., C.I. MOSELEY, B.E.B . Molecular biology of radiation resistant bacteria. HERBERT, R. A., SHARP, R. J., In Molecular Biology and Biotechnology of Extremophiles, p. 258-277, 1992.

SOTIN, C., GRASSET, O., MOCQUET, A.. Mass radius curve for extrasolar Earthlike planets and ocean planets Icarus, v. 191, p. 337-351, 2007.

SOUtham, G., ROThSCHILD, L. J., WESTALL, F.. The Geology and Habitability of Terrestrial Planets: Fundamental Requirements for Life, Space Sci. Rev., v. 129, p. 7-34, 2007.

STERN, S. A., LEVISON, H. F.. Regarding the criteria for planethood and proposed planetary classification schemes, Highlights of Astronomy, v. 12, p. 205-213, 2002.

STERN, S. A., LEVISON, H. F.. Regarding the criteria for planethood and proposed 
planetary classification schemes, Highlights of Astronomy, v. 12, p. 205-213, 2002.

STETTER, KARL. Hyperthermophilic procaryotes, FEMS Microbiology Reviews, v. 18, n. 2-3, p. 149-158, 1996.

STETTER, K. O.. Ultrathin mycelia-forming organisms from submarine volcanic areas having an optimum growth temperature of $105{ }^{\circ}$ C, Nature, v. 300, p. 258-260, 1982.

STEVEnS, T. O., MCKINLEY, J. P.. Lithoautotrophic Microbia, Ecosystems in Deep Basalt Aquifers, Science, v. 270, p. 450-454, 1995.

STEVENS, I. R. et al.. Neutron stars and planet-mass companions, MNRAS, v. 254, p. 19P-22P, 1992.

STOREY, KENNETH, STOREY, JANET. Natural freezing survival in animals, Annual Review of Ecology and Systematics, v. 27, p. 365-386, 1996.

TAWFIK, DAN S., GRIFFITHS, ANDREW D.. Man-made cell-like compartments for molecular evolution, Nature Biotechnology, v. 16, p. 652-656, 1998.

THOMAS, P. C.. Differentiation of the asteroid Ceres as revealed by its shape, Nature, v. 437, p. 224-226, 2005.

TORSVIK, T. et al.. Evidence for microbial activity at the glass-alteration interface in oceanic basalts, Earth and Planetary Science Letters, v. 162, p. 165-176, 1998.

TOUBOUL, M. et al.. Late formation and prolonged differentiation of the Moon inferred from $W$ isotopes in lunar metals, Nature, v. 450, p. 1206-1209, 2007.

TURCK-CHIEZE, S.. Revisiting the standard solar model, ApJ, 335, 415-424, 1988.

UREY, H. C.. On the Early Chemical History of the Earth and the Origin of Life, Proceedings of the National Academy of Science, v. 38, p. 351-363, 1952.

UDRY, S., SANTOS, N. C.. Statistical Properties of Exoplanets, ARA\&A, 45, 397-439, 2007.

VALENCIA, D., O'CONNELL, R. J., SASSELOV, D.. Structure of massive terrestrial planets, Icarus, v. 181, p. 545-554, 2006.

WARD, P., BROWNLEE, D.. Rare earth : why complex life is uncommon in the universe, 2000.

WARD, W. R.. Protoplanet Migration by Nebula Tides, Icarus, v. 126, p. 261-281, 1997.

WARD, W. R.. Density waves in the solar nebula - Differential Lindblad torque, Icarus, v. 67, p. $164-180,1986$. 
WALKER, J. C. G.. Carbon dioxide on the early earth, Origins of Life, v. 16, p. 117-127, 1985.

WEBER, PETER, GREENBERG, J. MAYO. Can spores survive in interstellar space?, Nature, v. 316, p. 403-407, 1985.

WEIDNER, C., HORNE, K., Limits on the orbits and masses of moons around currently-known transiting exoplanets, A\&A, v. 521, p. A76, 2010.

WEIDENSCHILLING, S. J., MARZARI, F.. Gravitational scattering as a possible origin for giant planets at small stellar distances, Nature, v. 384, p. 619-621, 1996.

WEISS, B. P., YUNG, Y. L., NEALSON, K. H.. Atmospheric energy for subsurface life on Mars?, Proceedings of the National Academy of Science, v. 97, p. 1395-1399, 2000.

WEISS, B. P. et al.. A Low Temperature Transfer of ALH84001 from Mars to Earth, Science, v. 290, p. 791-795, 2000.

WHARTON, D, FERNS, D. Survival of intracellular freezing by the antarctic nematode panagrolaimus davidi, J Exp Biol, v. 198, n. 6, p. 1381-1387, 1995.

WHITMIRE, D. P. et al.. Habitable Zones for Earth-like Planets Around Main Sequence Stars, in: HEIDMANN, J., KLEIN, M. J., Bioastronomy: The search for extraterrestial life the exploration broadens, Lecture Notes in Physics, Berlin Springer Verlag, v. 390, p. 173-178, 1991.

WILLIAMS, D. M. et al.. Habitable moons around extrasolar giant planets, Nature, v. 385, p. 234-236, 1997.

WILlIAMS, D. M., KASTING, J. F.. Habitable Planets with High Obliquities, Icarus, v. 129, p. 254-267, 1997.

WOOLF, N., ANGEL, J. R.. Astronomical Searches for Earth-Like Planets and Signs of Life, ARA\&A, v. 36, p. 507-538, 1998.

YI, S. K. et al.. The $Y^{2}$ Stellar Evolutionary Tracks, ApJS, v. 144, p. 259-261, 2003.

ZAHNLE, K. et al.. Emergence of a Habitable Planet, in: FISHBAUGH, K. E., et al., Geology and habitability of terrestrial planets, space sciences series of issi, springer science+business media, v. 24, p. 35, 2007.

ZAHNLE, K. J. et al.. Evolution of a steam atmosphere during earth's accretion, Icarus, v. 74, p. 62-97, 1988.

ZAHNLE, K. J., WALKER, J. C. G.. The evolution of solar ultraviolet luminosity, 
Reviews of Geophysics and Space Physics, v. 20, p. 280-292, 1982. 
Apêndice 

Apêndice A

\section{Evolução dos Satélites Naturais (Exoluas)}

O principal método que descreve a evolução orbital de um satélite associa o surgimento de uma perturbação na órbita da lua ocasionada pelo efeito de maré planetário (tidal bulge) que, por sua vez, foi originado pela interação entre esses dois corpos. Quando a velocidade angular de rotação do planeta é igual a velocidade angular orbital da lua, a perturbação de maré induzida pelo satélite é direcionada na linha que une os objetos, não existindo troca de momento angular entre a rotação do planeta e a órbita do satélite. Entretanto, caso o planeta tenha velocidade de rotação distinta (maior ou menor) da velocidade orbital da lua, a perturbação de maré do planeta é arrastada para frente ou para trás da linha que une esses corpos por um ângulo $\delta$, que é definido em termos do parâmetro de dissipação $Q_{p}$, através da relação $\operatorname{tg}(2 \delta)=\frac{1}{Q_{p}}$. A interação gravitacional entre a perturbação assimétrica e a lua permitirá uma troca de momento angular entre a rotação do planeta e a órbita da lua; esse processo pode levar a um aumento ou decréscimo do raio orbital dela. Murray e Dermott (1999) estimaram o torque sofrido pelo satélite devido à perturbação de maré do planeta:

$$
\tau_{p-m}=\frac{3}{2} \frac{k_{2 p} G M_{m}^{2} R_{p}^{5}}{Q_{p} a_{m}^{6}} \operatorname{sgn}\left(n_{p, r o t}-n_{m}\right),
$$

onde $G$ é a constante gravitacional universal, $k_{2 p}$ o número de tidal Love do planeta, $M_{p}$ a massa do planeta, $R_{p}$ o raio do planeta, $a_{m}$ o semi-eixo maior da lua, $M_{m}$ a massa da lua, $n_{p, r o t}$ e $n_{m}$, as velocidades angulares associadas com a rotação do planeta e com a órbita da lua, respectivamente.

Considerando que, o torque exercido pelo planeta ocasionando a evolução da órbita da lua é igual à mudança do momento angular do corpo de menor massa, é possível representar 
o valor de $a_{m}$ através de parâmetros físicos dos dois corpos em interação (Barnes e O' Brien, 2002):

$$
\tau_{p-m}=\frac{d}{d t}\left(a_{m}^{2} M_{m} n_{m}\right)
$$

Através da Lei de Kepler, dada por $a_{m}^{3} n_{m}^{2}=G M_{p}$, mais as equações A.1 e A.2, tem-se:

$$
\frac{d a_{m}}{d t}=3 \frac{k_{2 p} G M_{m} R_{p}^{5}}{\sqrt{G M_{p}} Q_{p} a_{m}^{\frac{11}{2}}} \operatorname{sgn}\left(n_{p, r o t}-n_{m}\right)
$$

Assumindo que a taxa de rotação do planeta não muda durante a evolução do sistema, o termo $n_{p, r o t}-n_{m}$ não sofre troca de sinal e a equação A.3 pode ser integrada, originando duas equações que descrevem o comportamento de $a_{m}$ em função do tempo:

$$
a_{m}(t)=\left[a_{m}\left(t_{0}\right)^{\frac{13}{2}}+\left(t-t_{0}\right) \frac{32}{2} \frac{k_{2 p} G M_{m} R_{p}^{5}}{\sqrt{G M_{p}} Q_{p}}\right]^{\frac{2}{13}}
$$

para migração externas $\left(n_{p, r o t}>n_{m}\right)$ e

$$
a_{m}(t)=\left[a_{m}\left(t_{0}\right)^{\frac{13}{2}}-\left(t-t_{0}\right) \frac{32}{2} \frac{k_{2 p} G M_{m} R_{p}^{5}}{\sqrt{G M_{p}} Q_{p}}\right]^{\frac{2}{13}}
$$

para migração interna $\left(n_{p, r o t}<n_{m}\right)$. Nas equações acima, $t$ é o tempo atual e $t_{0}$ é o tempo em que a lua foi formada.

Outro processo de migração que tenta explicar a mudança de órbitas lunares é conhecido como migração planetária dirigida pelo disco protoplanetário e ocorre em escalas de tempo bem menores do que a migração induzida por forças de maré. Nesse cenário, o raio de Hill planetário diminui rapidamente, deixando o satélite, que antes estava localizado em seu interior, fora dessa região e com a possibilidade de sofrer o processo de mudança de órbita. Planetas gigantes gasosos que atingem órbitas de aproximadamente $0,1 U A$, dificilmente apresentarão satélites (Namouni, 2010); fica evidente que planetas gigantes gasosos apresentando períodos orbitais pequenos não são aptos a abrigarem satélites naturais e, por esse motivo, devem ser alvos menos relevantes na busca de exoluas em futuros projetos observacionais. 
Apêndice B

\section{Sistemas Extrasolares Analisados}

\section{B.1 Características dos Sistemas Extrasolares}

A tabela B.1 apresenta algumas características dos sistemas extrasolares estudados. Ela informa a idade provável deles, assim como a massa e o tempo aproximado de permanência na Sequência Principal de suas estrelas hospedeiras. Também é delimitado os limites interno e externo das ZH e ZE, considerando a idade aproximada de cada sistema extrasolar.

Tabela B.1 - Algumas das características dos sistemas extrasolares analisados.

\begin{tabular}{ccccccc}
\hline \hline Sistema & $M_{s}\left(M_{\odot}\right)$ & $T_{S P}(G$ anos $)$ & Idade $(G$ anos $)$ & $Z H(U A)$ & $Z E(U A)$ & $N^{o}$ de Planetas \\
\hline \hline GJ $676 C$ & 0,33 & $91,83-278,26$ & 5,00 & $0,11-0,27$ & $0,10-0,35$ & 2 \\
\hline \hline GL 581 & 0,31 & $104,05-335,67$ & 8,00 & $0,117-0,284$ & $0,115-0,369$ & 4 \\
\hline \hline GL 876 & 0,33 & $91,83-278,26$ & 2,50 & $0,103-0,249$ & $0,101-0,324$ & 3 \\
\hline \hline HD 10697 & 1,15 & $6,57-7,56$ & 6,90 & $1,39-3,38$ & $1,37-4,40$ & 1 \\
\hline \hline HD 141937 & 1,10 & $7,51-8,26$ & 2,55 & $1,07-2,58$ & $1,05-3,36$ & 1 \\
\hline \hline HD 183263 & 1,17 & $6,24-7,31$ & 8,10 & $1,55-3,76$ & $1,53-4,90$ & 2 \\
\hline \hline HD 202206 & 1,13 & $6,93-7,83$ & 2,04 & $1,08-2,62$ & $1,07-3,41$ & 2 \\
\hline \hline HD 213240 & 1,22 & $5,50-6,72$ & 5,11 & $1,43-3,45$ & $1,41-4,51$ & 1 \\
\hline \hline HD 222582 & 0,99 & $10,2-10,3$ & 6,16 & $0,99-2,42$ & $0,98-3,16$ & 1 \\
\hline \hline HD 37124 & 0,83 & $14,52-17,48$ & 3,30 & $0,63-1,54$ & $0,62-2,00$ & 3 \\
\hline \hline HD 38801 & 1,36 & $3,97-5,41$ & 4,67 & $1,65-4,02$ & $1,63-5,23$ & 1 \\
\hline \hline HD 50554 & 1,04 & $8,88-9,24$ & 4,58 & $1,03-2,49$ & $1,01-3,25$ & 1 \\
\hline \hline HD 85512 & 0,69 & $21,0-30,4$ & 5,60 & $0,48-1,17$ & $0,47-1,53$ & 1 \\
\hline \hline Kepler 22 & 0,97 & $10,63-10,95$ & 2,00 & $0,82-1,98$ & $0,81-2,58$ & 1 \\
\hline \hline mu Ara & 1,08 & $7,93-8,57$ & 6,41 & $1,20-2,92$ & $1,18-3,79$ & 4 \\
\hline \hline
\end{tabular}




\section{B.2 Características dos Exoplanetas}

A tabela B.2 apresenta o conjunto de exoplanetas analisados neste trabalho. Nela estão contidas as informações sobre a época de análise, a massa, o raio e o semi-eixo maior de cada planeta, assim como quais planetas encontram-se no interior das ZH e ZE. A tabela traz também informações sobre as distâncias e os períodos orbitais de eventuais exoluas, considerando a estabilidade do sistema. O raio de Roche foi calculado para exoluas com densidades semelhantes a da Terra e de Europa.

Tabela B.2 - Algumas características do conjunto de exoplanetas e suas eventuais exoluas.

\begin{tabular}{|c|c|c|c|c|c|c|c|c|c|c|}
\hline Planeta & $\mathrm{T}_{\text {análise }}(\mathrm{G}$ anos$)$ & $\mathrm{M}_{p}\left(\mathrm{M}_{J}\right)$ & $\mathrm{a} p(\mathrm{UA})$ & $\mathrm{R}_{p}\left(\mathrm{R}_{J}\right)$ & $\mathrm{ZH}$ & $\mathrm{ZE}$ & $\mathrm{M}_{\text {exolua }}^{\min }\left(\mathrm{M}_{\oplus}\right)$ & $\mathrm{R}_{R}\left(\mathrm{R}_{J}\right)$ & $\mathrm{R}_{m a ́ x, p}\left(\mathrm{R}_{J}\right)$ & $\mathrm{P}_{\text {exolua }}^{\text {est }}$ (dias) \\
\hline GJ $676 \mathrm{Cb}$ & 5,00 & 0,02 & 0,05 & - & não & não & - & - & - & - \\
\hline GJ $676 \mathrm{Cc}$ & 5,00 & 0,01 & 0,12 & 0,13 & $\operatorname{sim}$ & $\operatorname{sim}$ & abaixo de $0,02 \mathrm{M}_{\oplus}$ & $0,36 / 0,44$ & 3,18 & $0,30-5,87$ \\
\hline GL $581 \mathrm{~b}$ & 8,00 & 0,05 & 0,04 & - & não & não & - & - & - & - \\
\hline GL $581 \mathrm{c}$ & 8,00 & 0,02 & 0,07 & - & não & não & - & - & - & - \\
\hline GL $581 \mathrm{~d}$ & 8,00 & 0,02 & 0,22 & 0,14 & $\operatorname{sim}$ & $\operatorname{sim}$ & abaixo de $0,01 \mathrm{M}_{\oplus}$ & $0,39 / 0,48$ & 6,06 & $0,29-13,37$ \\
\hline GL $581 \mathrm{e}$ & 8,00 & 0,006 & 0,028 & - & não & não & - & - & - & - \\
\hline GL $876 b$ & 2,50 & 2,27 & 0,21 & 1,28 & $\operatorname{sim}$ & $\operatorname{sim}$ & acima ou abaixo de $1 \mathrm{M}_{\oplus}$ & $1,95 / 2,39$ & 27,8 & $0,22-11,98$ \\
\hline GL $876 \mathrm{c}$ & 2,50 & 0,71 & 0,13 & 0,87 & $\operatorname{sim}$ & $\operatorname{sim}$ & acima ou abaixo de1 $\mathrm{M}_{\oplus}$ & $1,33-1,62$ & 23,9 & $0,22-17,05$ \\
\hline GL $876 \mathrm{~d}$ & 2,50 & 0,02 & 0,02 & - & não & não & - & - & - & - \\
\hline GL $876 \mathrm{e}$ & 2,50 & 0,05 & 0,33 & - & não & não & - & - & - & - \\
\hline HD $10697 \mathrm{~b}$ & 6,90 & 6,38 & 2,16 & 1,81 & $\operatorname{sim}$ & $\operatorname{sim}$ & acima ou abaixo de $1 \mathrm{M}_{\oplus}$ & $2,76 / 3,38$ & 267,70 & $0,22-213,70$ \\
\hline HD $11506 \mathrm{~b}$ & 5,40 & 3,44 & 2,43 & 1,48 & $\operatorname{sim}$ & $\operatorname{sim}$ & acima ou abaixo de $1 \mathrm{M}_{\oplus}$ & $2,25 / 2,75$ & 242,40 & $0,22-250,70$ \\
\hline HD $11506 \mathrm{c}$ & 5,40 & 0,82 & 0,64 & - & não & não & - & - & - & - \\
\hline HD $141937 \mathrm{~b}$ & 2,50 & 9,70 & 1,52 & 2,08 & $\operatorname{sim}$ & $\operatorname{sim}$ & acima ou abaixo de $1 \mathrm{M}_{\oplus}$ & $3,17 / 3,88$ & 219,89 & $0,22-189,10$ \\
\hline HD $183263 b$ & 8,10 & 3,67 & 1,51 & - & não & não & - & - & - & - \\
\hline HD $183263 \mathrm{c}$ & 8,10 & 3,82 & 4,25 & 1,53 & não & $\operatorname{sim}$ & acima ou abaixo de $1 \mathrm{M}_{\oplus}$ & $2,32 / 2,85$ & 441,50 & $0,22-584,88$ \\
\hline HD $202206 \mathrm{~b}$ & 2,04 & 17,4 & 0,83 & - & não & não & - & - & - & - \\
\hline HD 202206c & 2,04 & 2,44 & 2,55 & 1,32 & $\operatorname{sim}$ & $\operatorname{sim}$ & acima ou abaixo de $1 \mathrm{M}_{\oplus}$ & $2,00 / 2,45$ & 230,79 & $0,22-276,52$ \\
\hline HD $213240 \mathrm{~b}$ & 5,11 & 4,50 & 2,03 & 1,62 & $\operatorname{sim}$ & $\operatorname{sim}$ & acima ou abaixo de $1 \mathrm{M}_{\oplus}$ & $2,45 / 3,00$ & 219,62 & $0,22-189,07$ \\
\hline HD $222582 b$ & 6,16 & 7,75 & 1,35 & 1,94 & $\operatorname{sim}$ & $\operatorname{sim}$ & acima ou abaixo de $1 \mathrm{M}_{\oplus}$ & $2,94 / 3,60$ & 187,70 & $0,22-113,85$ \\
\hline HD $37124 \mathrm{~b}$ & 3,33 & 0,67 & 0,53 & - & não & não & - & - & - & - \\
\hline HD $37124 \mathrm{c}$ & 3,33 & 0,65 & 1,71 & 0,85 & não & $\operatorname{sim}$ & acima ou abaixo de $1 \mathrm{M}_{\oplus}$ & $1,28 / 1,57$ & 110,00 & $0,22-175,00$ \\
\hline HD $37124 d$ & 3,33 & 0,69 & 2,81 & - & não & não & - & - & - & - \\
\hline HD $38801 b$ & 4,67 & 10,70 & 1,70 & 2,15 & $\operatorname{sim}$ & $\operatorname{sim}$ & acima ou abaixo de $1 \mathrm{M}_{\oplus}$ & $3,27 / 4,01$ & 242,33 & $0,22-142,15$ \\
\hline HD $50554 \mathrm{~b}$ & 4,58 & 5,16 & 2,41 & 1,69 & $\operatorname{sim}$ & $\operatorname{sim}$ & acima ou abaixo de $1 \mathrm{M}_{\oplus}$ & $2,57 / 3,15$ & 287,80 & $0,22-264,89$ \\
\hline HD $85512 b$ & 5,61 & 0,01 & 0,26 & - & não & não & - & - & - & - \\
\hline Kepler 22b & 2,00 & 0,11 & 0,85 & 0,21 & $\operatorname{sim}$ & $\operatorname{sim}$ & acima ou abaixo de $1 \mathrm{M}_{\oplus}$ & $0,71 / 0,87$ & 28,70 & $0,22-56,35$ \\
\hline mu Ara b & 6,41 & 1,67 & 1,50 & 1,16 & $\operatorname{sim}$ & $\operatorname{sim}$ & acima ou abaixo de1 $\mathrm{M}_{\oplus}$ & $2,16 / 1,76$ & 121,60 & $0,30-127,56$ \\
\hline mu Ara c & 6,41 & 0,03 & 0,09 & - & não & não & - & - & - & - \\
\hline mu Ara d & 6,41 & 0,52 & 0,92 & - & não & não & - & - & - & - \\
\hline mu Ara e & 6,41 & 1,81 & 5,24 & - & não & não & - & - & - & - \\
\hline
\end{tabular}


Apêndice C

\section{Análise dos Exoplanetas}

\section{Sistema Gliese 876}

(a)

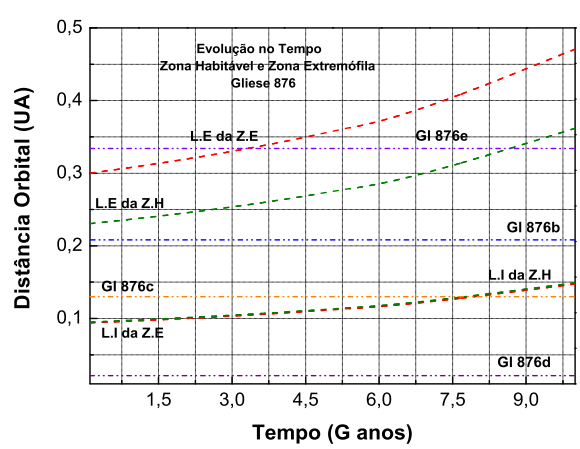

(b)

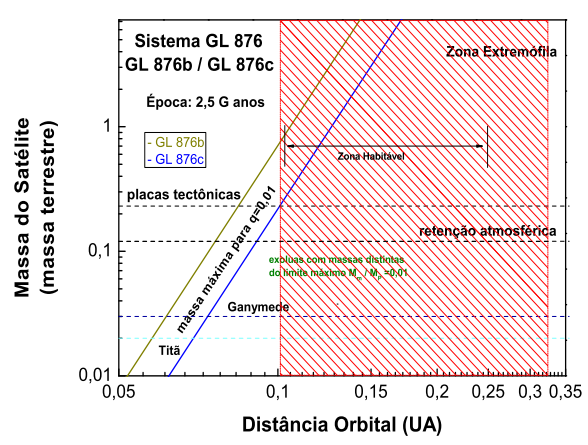

Figura C.1: Análise da habitabilidade para o Sistema Gliese 876: (a) e (b) mostram as Zonas Habitável e Extremófila contínuas e o valor aproximado da massa máxima de uma eventual exolua em função do semi-eixo maior do planeta.

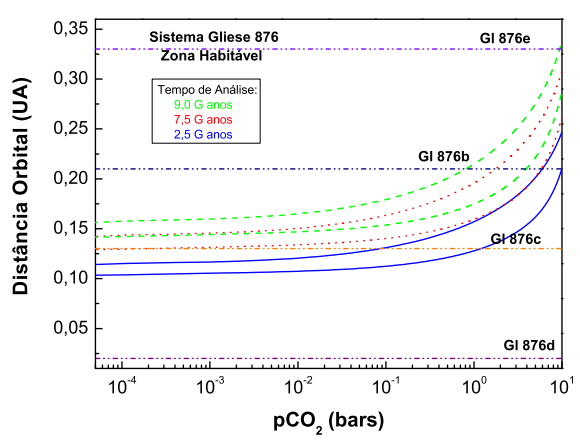

(a)

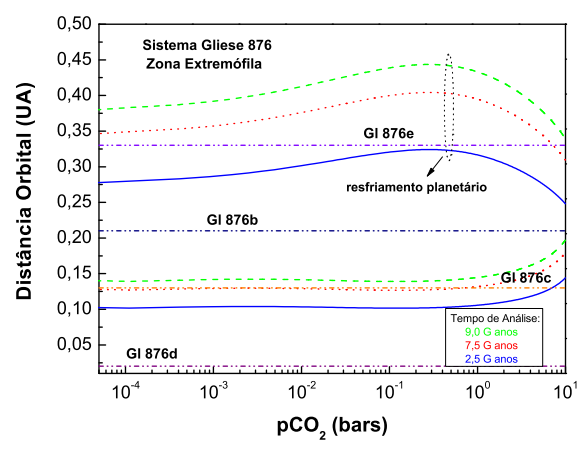

(b)

Figura C.2: Análise da habitabilidade para o Sistema Gliese 876: (a) e (b) mostram as Zonas Habitável e Extremófila em função da pressão de dióxido de carbono para o sistema em épocas aproximadas de 2,5, 7, 5 e 9,0 bilhões de anos, respectivamente. 
Sistema HD 10697

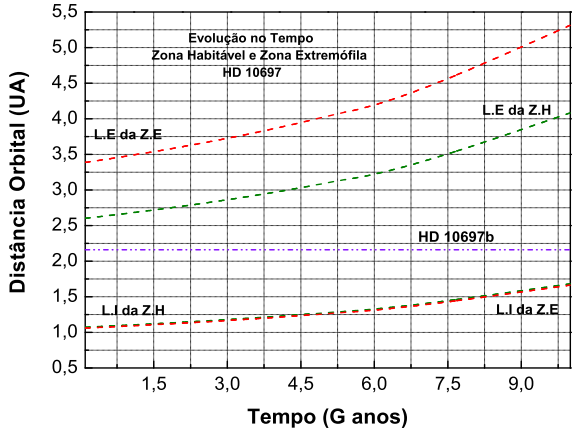

(a)

(b)

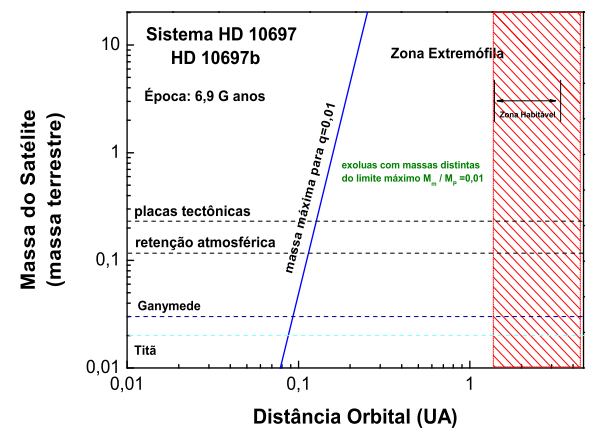

Figura C.3: Análise da habitabilidade para o Sistema HD 10697: (a) e (b) mostram as Zonas Habitável e Extremófila contínuas e o valor aproximado da massa máxima de uma eventual exolua em função do semi-eixo maior do planeta.

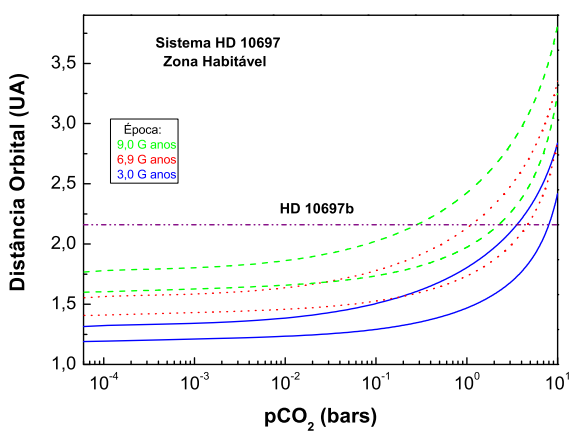

(a)

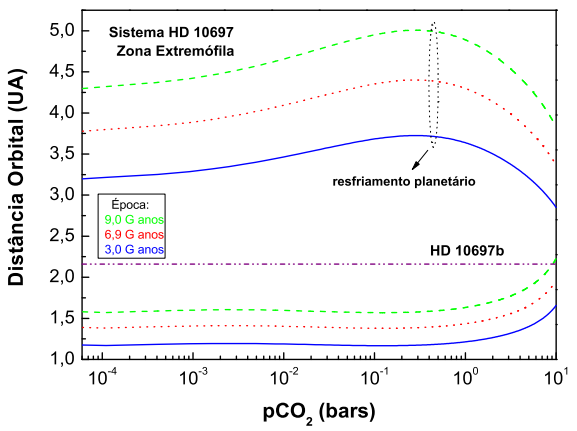

(b)

Figura C.4: Análise da habitabilidade para o Sistema HD 10697: (a) e (b) mostram as Zonas Habitável e Extremófila em função da pressão de dióxido de carbono para o sistema em épocas aproximadas de 3,0 , 6,9 e 9,0 bilhões de anos respectivamente. 
Sistema HD 11506

(a)

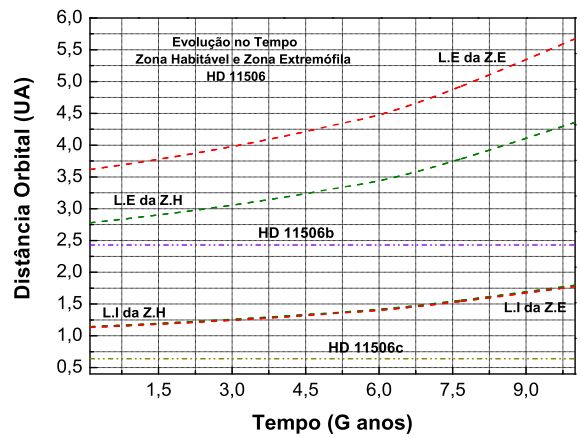

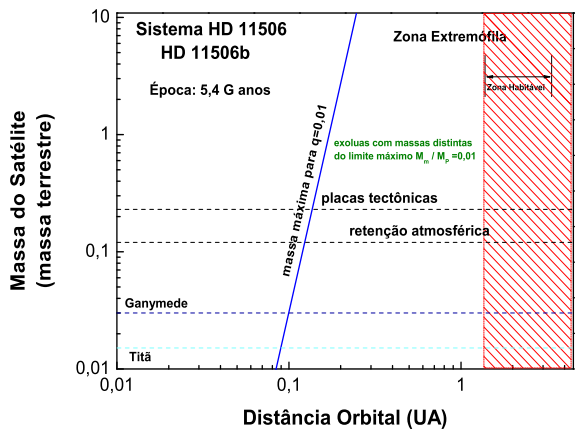

(b)

Figura C.5: Análise da habitabilidade para o Sistema HD 11506: (a) e (b) mostram as Zonas Habitável e Extremófila contínuas e o valor aproximado da massa máxima de uma eventual exolua em função do semi-eixo maior do planeta.

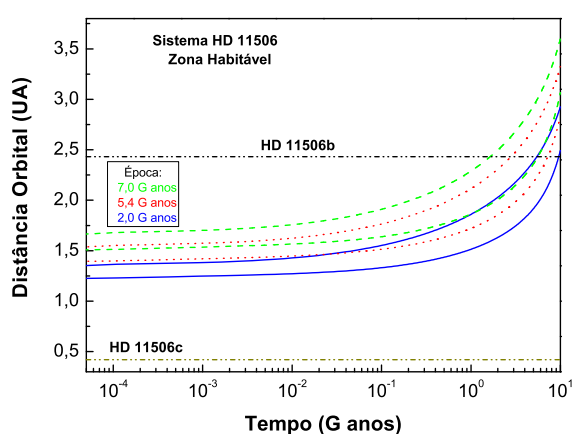

(a)

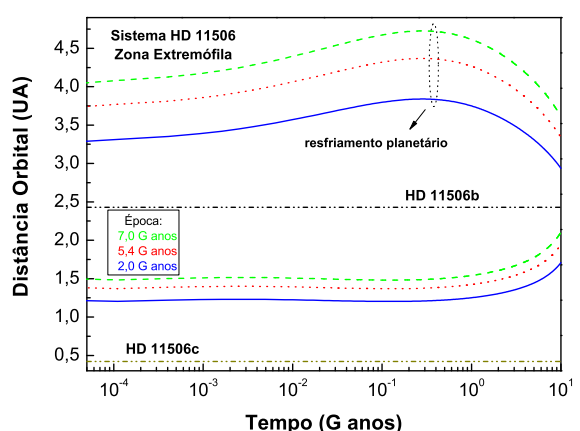

(b)

Figura C.6: Análise da habitabilidade para o Sistema HD 11506: (a) e (b) mostram as Zonas Habitável e Extremófila em função da pressão de dióxido de carbono para o sistema em épocas aproximadas de 2,0 , 5,4 e 7,0 bilhões de anos respectivamente. 
(a)
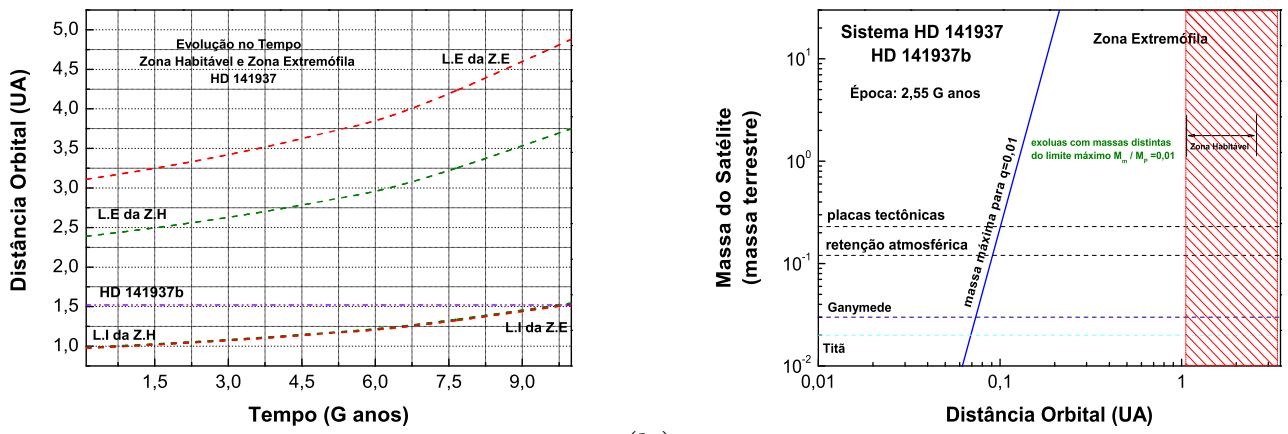

(b)

Figura C.7: Análise da habitabilidade para o Sistema HD 141937: (a) e (b) mostram as Zonas Habitável e Extremófila contínuas e o valor aproximado da massa máxima de uma eventual exolua em função do semi-eixo maior do planeta.

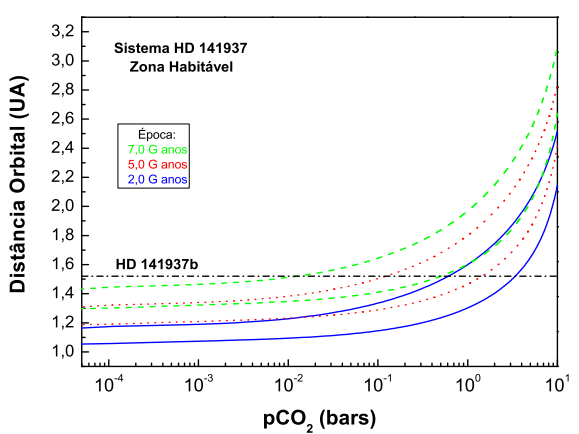

(a)

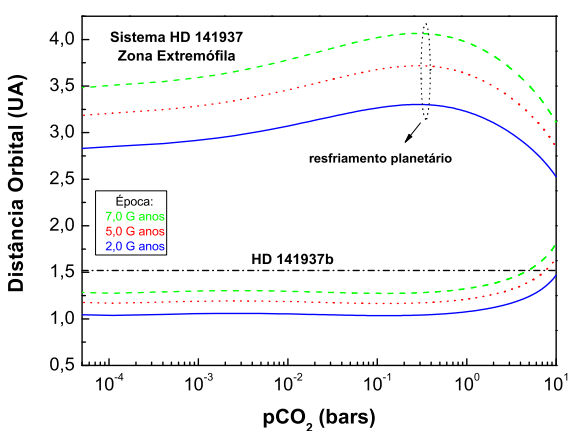

(b)

Figura C.8: Análise da habitabilidade para o Sistema HD 141937: (a) e (b) mostram as Zonas Habitável e Extremófila em função da pressão de dióxido de carbono para o sistema em épocas aproximadas de 2,0, 5, 0 e 7,0 bilhões de anos respectivamente. 


\section{Sistema HD 183263}

(a)

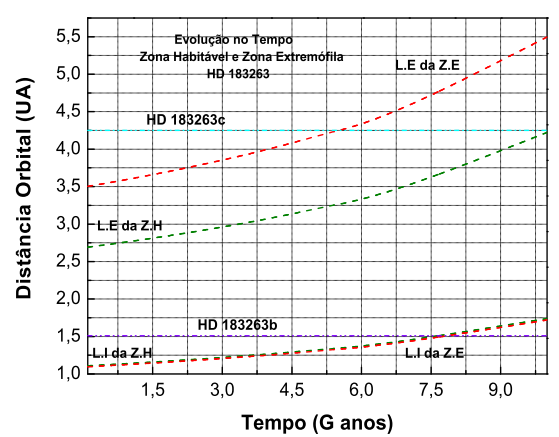

Figura C.9: Análise da habitabilidade para o Sistema HD 183263: (a) e (b) mostram as Zonas Habitável e Extremófila contínuas e o valor aproximado da massa máxima de uma eventual exolua em função do semi-eixo maior do planeta.

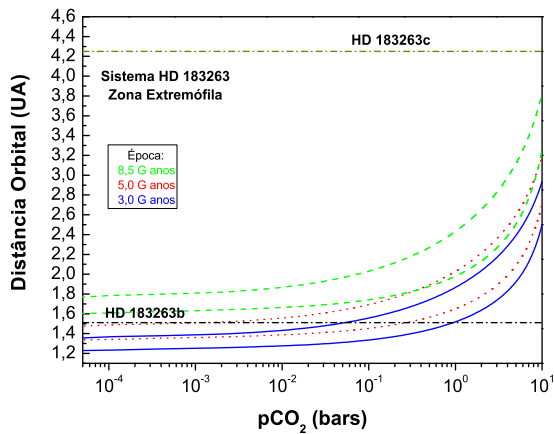

(a)

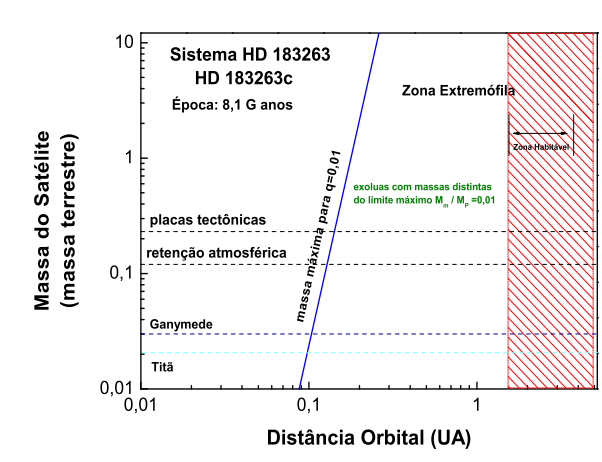

(b) 


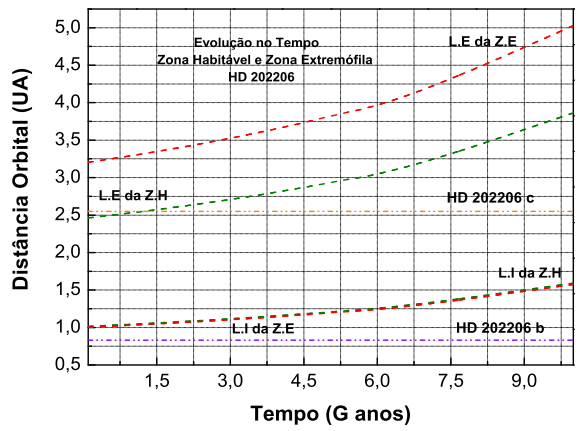

(a)

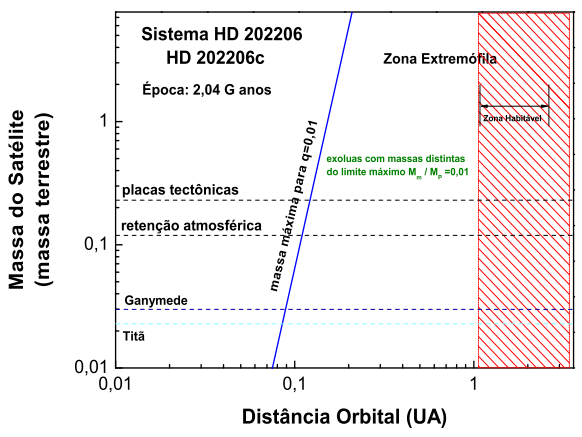

(b)

Figura C.11: Análise da habitabilidade para o Sistema HD 202206: (a) e (b) mostram as Zonas Habitável e Extremófila contínuas e o valor aproximado da massa máxima de uma eventual exolua em função do semi-eixo maior do planeta.

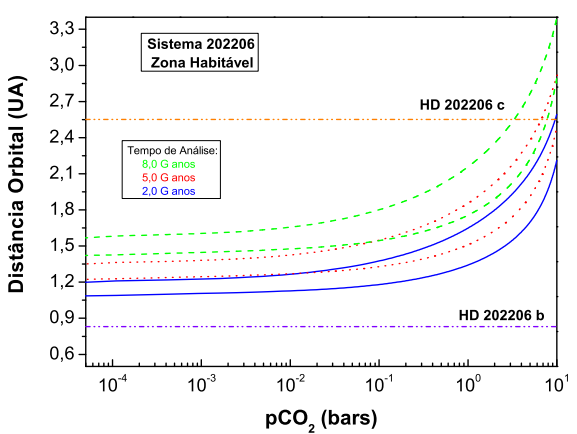

(a)

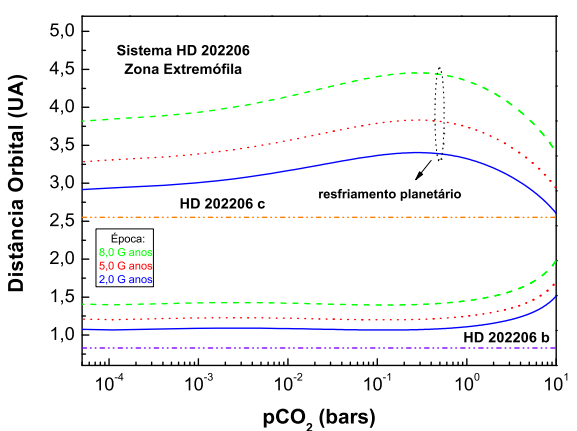

(b)

Figura C.12: Análise da habitabilidade para o Sistema HD 202206: (a) e (b) mostram as Zonas Habitável e Extremófila em função da pressão de dióxido de carbono para o sistema em épocas aproximadas de 2,0, 5, 0 e 8, 0 bilhões de anos respectivamente. 
Sistema HD 213240

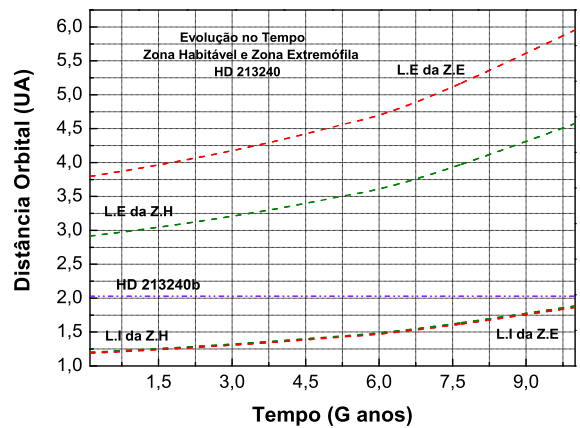

(a)

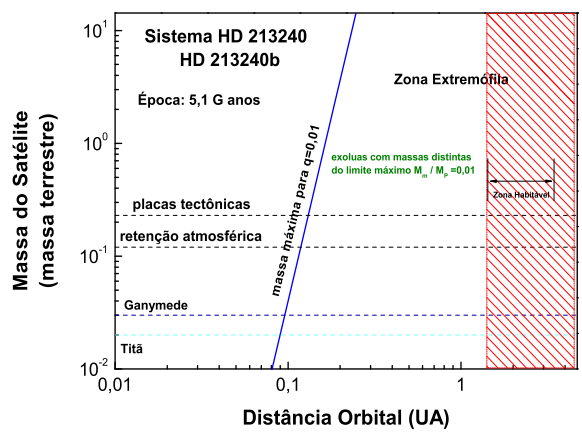

(b)

Figura C.13: Análise da habitabilidade para o Sistema HD 213240: (a) e (b) mostram as Zonas Habitável e Extremófila contínuas e o valor aproximado da massa máxima de uma eventual exolua em função do semi-eixo maior do planeta.

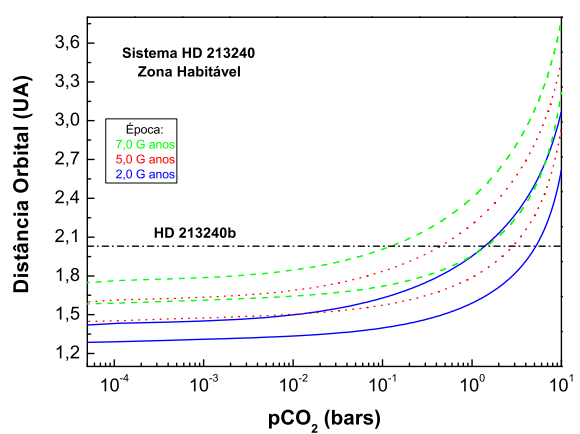

(a)

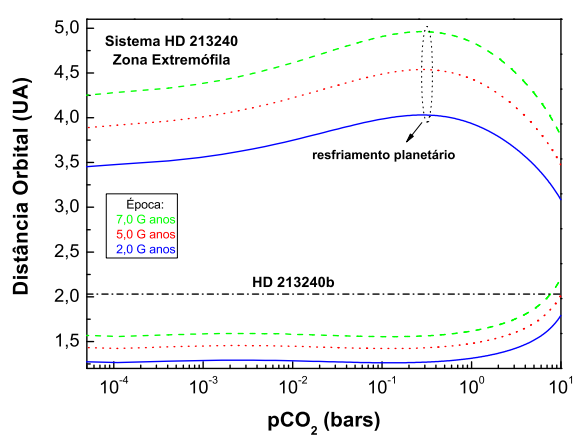

(b)

Figura C.14: Análise da habitabilidade para o Sistema HD 213240: (a) e (b) mostram as Zonas Habitável e Extremófila em função da pressão de dióxido de carbono para o sistema em épocas aproximadas de 2,0, 5, 0 e 7,0 bilhões de anos respectivamente. 
Sistema HD 222582

(a)

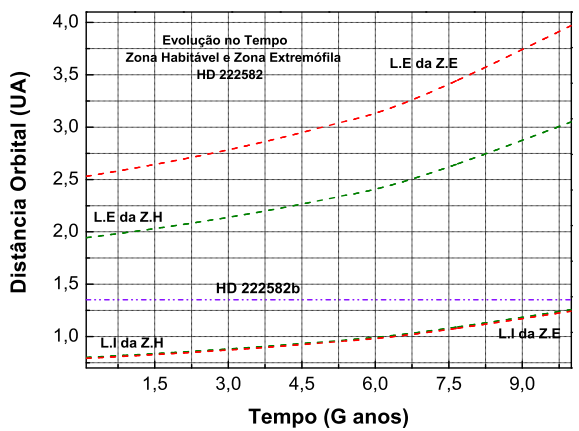

(b)

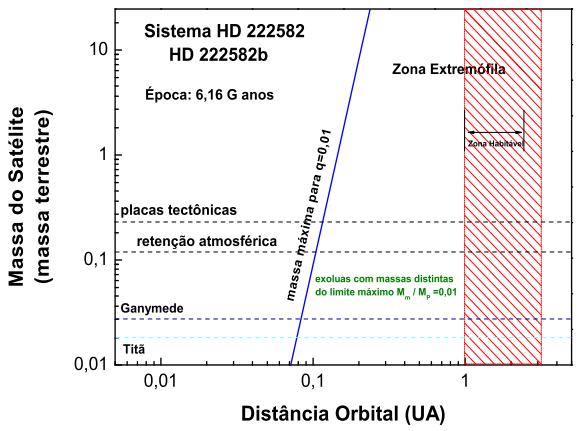

Figura C.15: Análise da habitabilidade para o Sistema HD 222582: (a) e (b) mostram as Zonas Habitável e Extremófila contínuas e o valor aproximado da massa máxima de uma eventual exolua em função do semi-eixo maior do planeta.

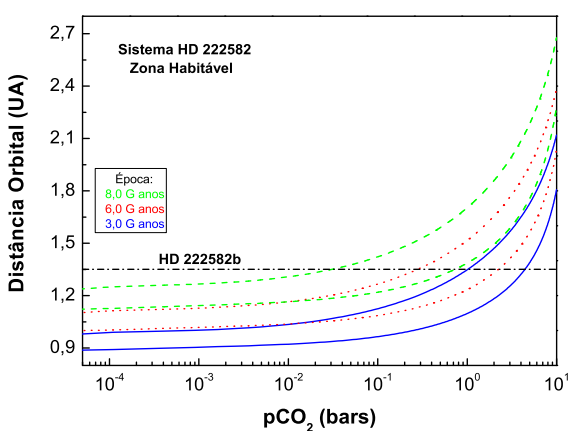

(a)

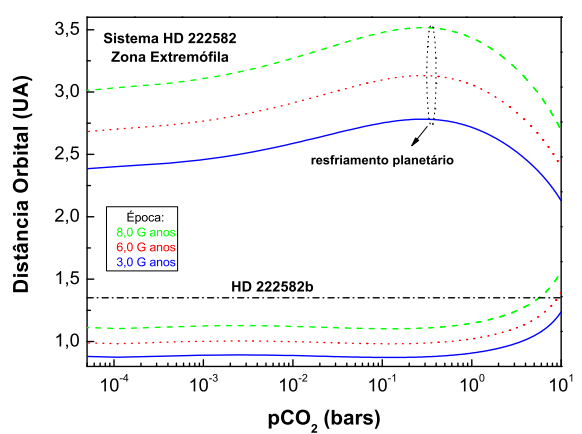

(b)

Figura C.16: Análise da habitabilidade para o Sistema HD 222582: (a) e (b) mostram as Zonas Habitável e Extremófila em função da pressão de dióxido de carbono para o sistema em épocas aproximadas de 3, 0, 6, 0 e 8, 0 bilhões de anos respectivamente. 


\section{Sistema HD 38801}

(a)

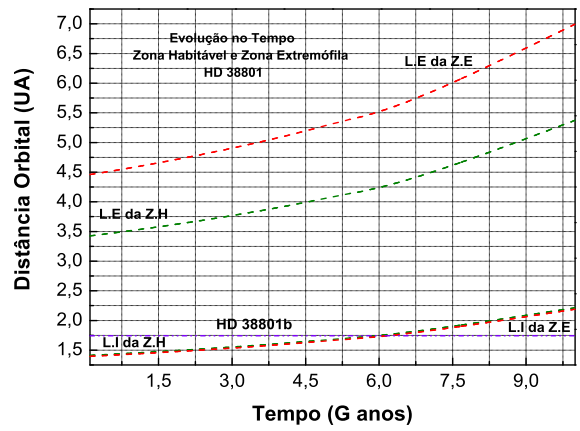

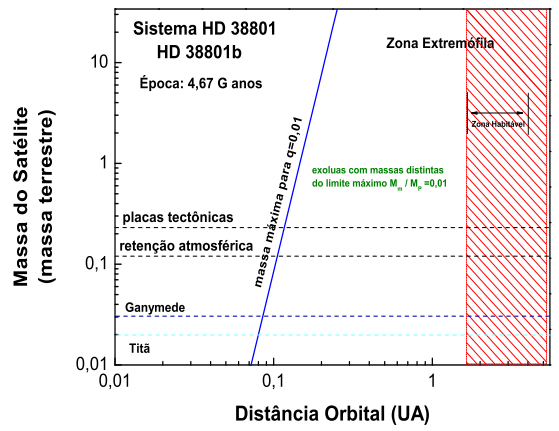

(b)

Figura C.17: Análise da habitabilidade para o Sistema HD 38801: (a) e (b) mostram as Zonas Habitável e Extremófila contínuas e o valor aproximado da massa máxima de uma eventual exolua em função do semi-eixo maior do planeta.

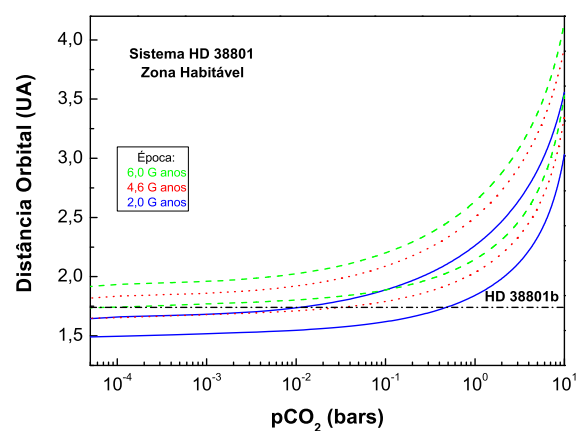

(a)

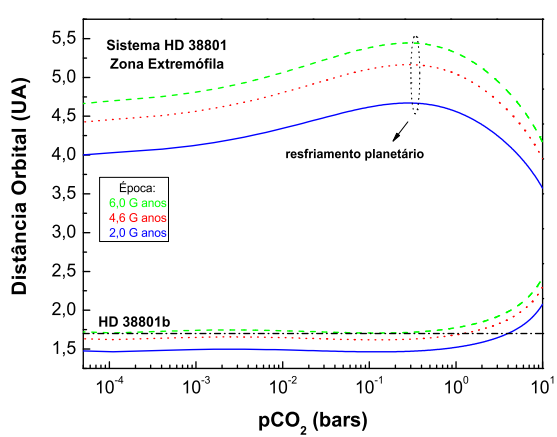

(b)

Figura C.18: Análise da habitabilidade para o Sistema HD 38801: (a) e (b) mostram as Zonas Habitável e Extremófila em função da pressão de dióxido de carbono para o sistema em épocas aproximadas de 2,0 , 4, 6 e 6,0 bilhões de anos respectivamente. 
Sistema HD 50554

(a)

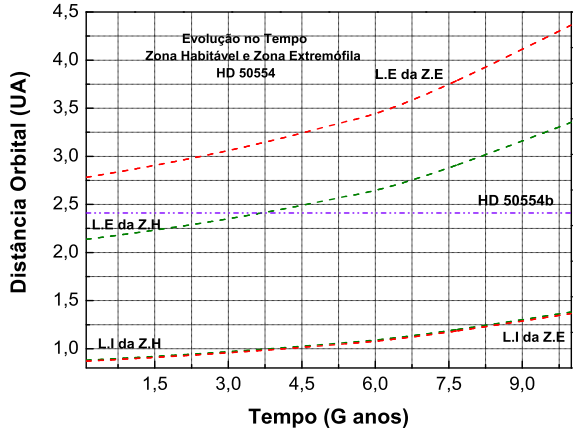

(b)

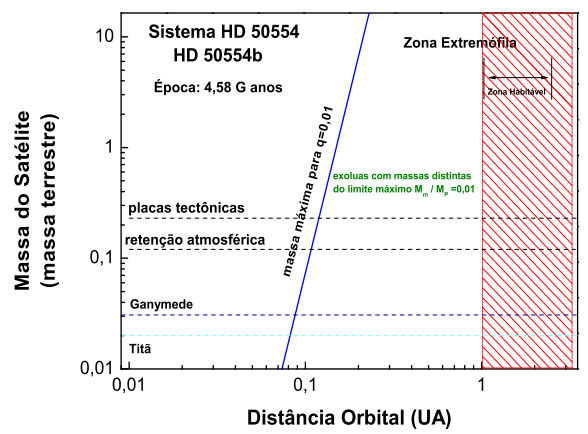

Distância Orbital (UA)

Figura C.19: Análise da habitabilidade para o Sistema HD 50554: (a) e (b) mostram as Zonas Habitável e Extremófila contínuas e o valor aproximado da massa máxima de uma eventual exolua em função do semi-eixo maior do planeta.

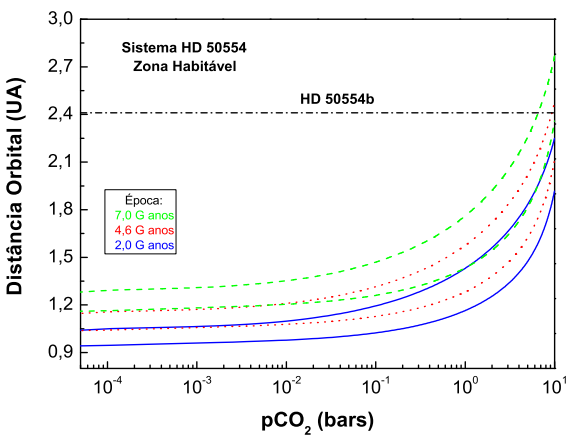

(a)

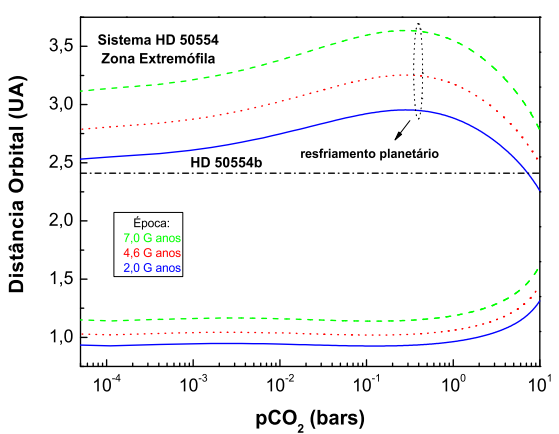

(b)

Figura C.20: Análise da habitabilidade para o Sistema HD 50554: (a) e (b) mostram as Zonas Habitável e Extremófila em função da pressão de dióxido de carbono para o sistema em épocas aproximadas de 2,0, 4, 6 e 7,0 bilhões de anos respectivamente. 
Sistema Kepler $22 b$

(a)

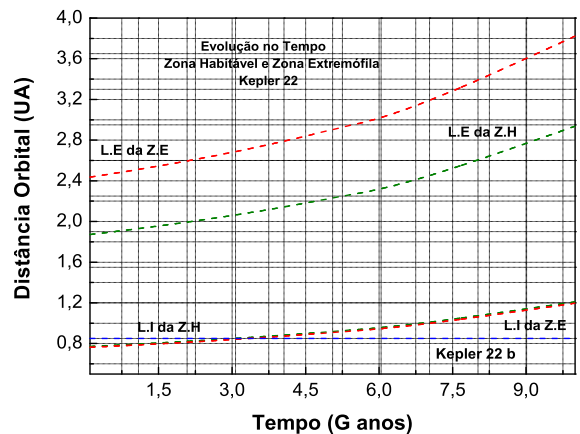

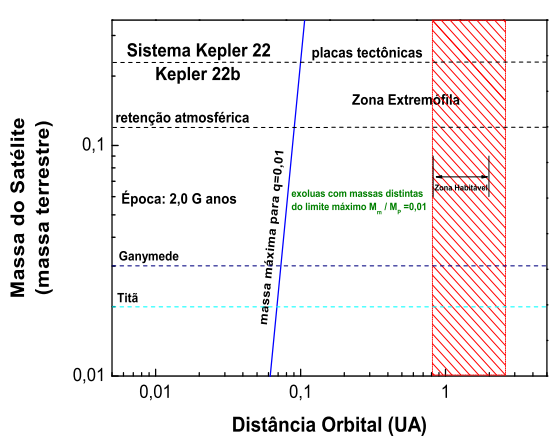

(b)

Figura C.21: Análise da habitabilidade para o Sistema Kepler 22b: (a) e (b) mostram as Zonas Habitável e Extremófila contínuas e o valor aproximado da massa máxima de uma eventual exolua em função do semi-eixo maior do planeta.

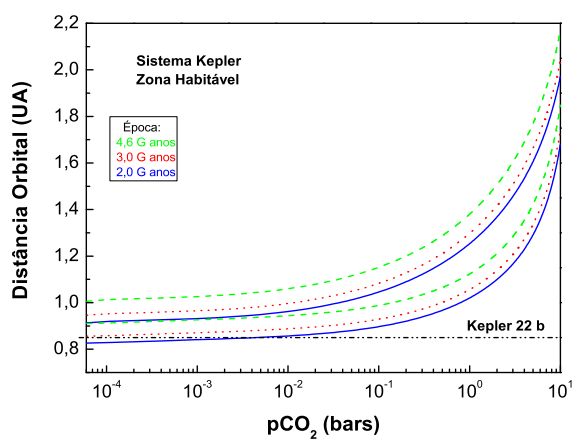

(a)

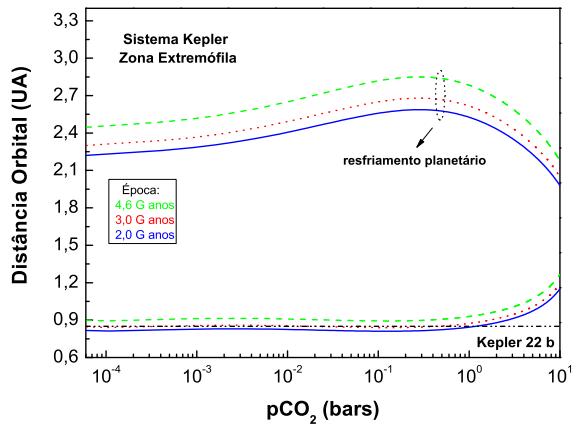

(b)

Figura C.22: Análise da habitabilidade para o Sistema Kepler 22b: (a) e (b) mostram as Zonas Habitável e Extremófila em função da pressão de dióxido de carbono para o sistema em épocas aproximadas de 2, 0 , 3,0 e 4, 6 bilhões de anos respectivamente. 


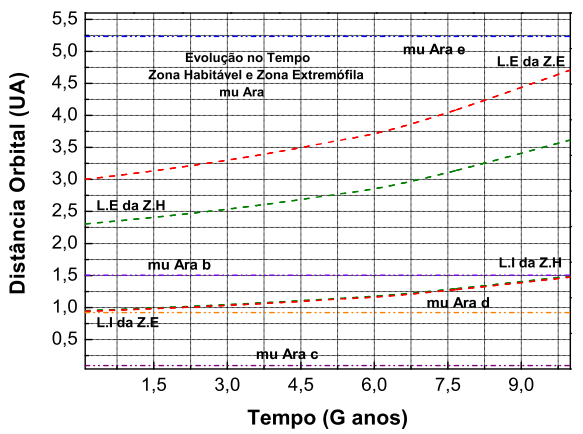

(a)

(b)

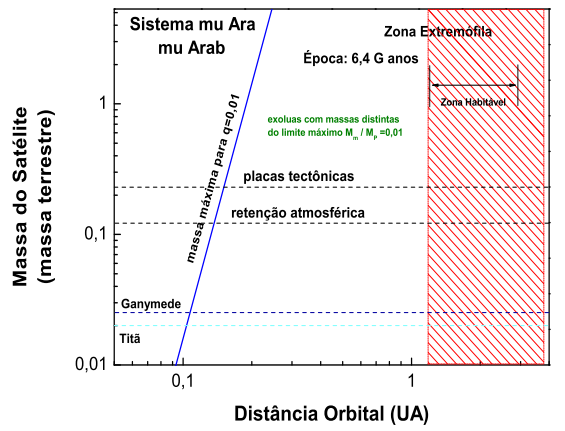

Distância Orbital (UA)

Figura C.23: Análise da habitabilidade para o Sistema mu Ara: (a) e (b) mostram as Zonas Habitável e Extremófila contínuas e o valor aproximado da massa máxima de uma eventual exolua em função do semi-eixo maior do planeta.

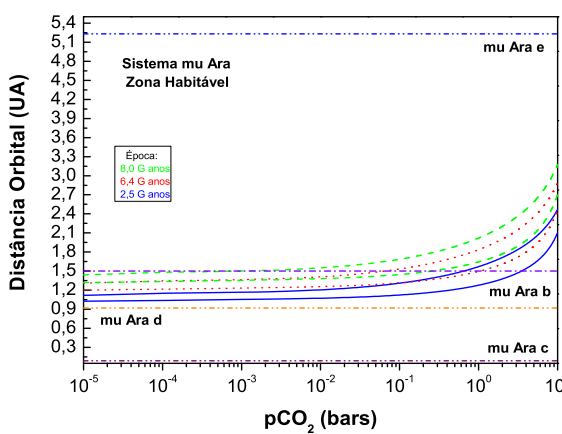

(a)

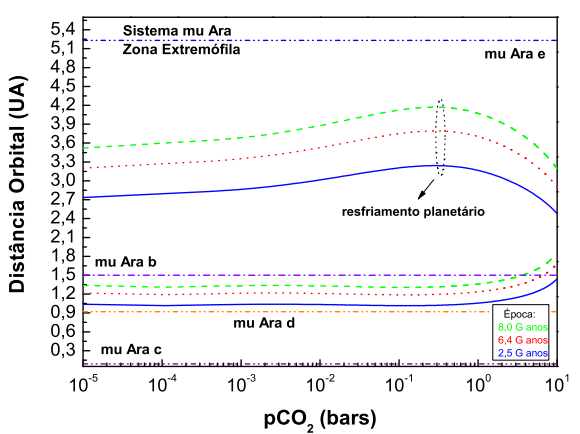

(b)

Figura C.24: Análise da habitabilidade para o Sistema mu Ara: (a) e (b) mostram as Zonas Habitável e Extremófila em função da pressão de dióxido de carbono para o sistema em épocas aproximadas de 2,5, 6, 4 e 8, 0 bilhões de anos respectivamente. 